J. S. G. S. (SW) LIAR

Albany, Now York

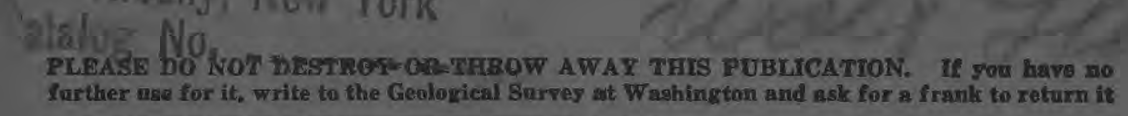

\begin{tabular}{|c|}
\hline UNITED STATES DEPARTMENT OF THE INTERIOR \\
\hline CONTRIBUTIONS \\
TO THE HYDROLOGY \\
OF THE UNITED STATES \\
1931 \\
\hline GEOLOGICAL SURVEY WATER-SUPPLY PAPER 638 \\
\hline
\end{tabular}


UNITED STATES DEPARTMENT OF THE INTERIOR

Ray Lyman Wilbur, Secretary

GEOLOGICAL SURVEY

W. C. Mendenhall, Director

Water-Supply Paper 638

\section{CONTRIBUTIONS TO THE HYDROLOGY OF THE UNITED STATES}

\section{1}

NATHAN C. GROVER, Chief Hydraulic Engineer

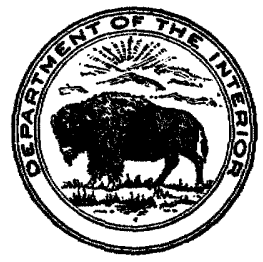

UNITED STATES

GOVERNMENT PRINTING OFFICE

WASHINGTON : 1932 


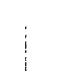




\section{CONTENTS}

[The letters in parentheses preceding the titles are those used to designate the papars for advance publication!

(A) A preliminary report on the artesian water supply of Memphis, Tenn., by F. G. Wells

Page

(B) Water-power resources of the Rogue River drainage basin, Oregon, by B. E. Jones, Warren Oakey, and H. T. Stearns_

(C) Outline of methods for estimating ground-water supplies, by $\mathrm{O}$. $\mathrm{E}$. Meinzer.

(D) Quality of water of the Colorado River in 1928-1930, by C.S. Howard. Index.

\section{ILLUSTRATIONS}

Prate 1. Map of Memphis, Tenn., showing location of wells

2. Altitude of the water level in the Auction Avenue "wet well" and the Central Avenue well, pumpage of the Memphis Artesian Water Department from the Wilcox group, altitude of the Mississippi River at Memphis, and rainfall at Bolivar, Tenn

3. Map of southwestern Oregon showing developed and proposed power sites in the Rogue River Basin.

4. Profile of the Rogue and Illinois Rivers showing location of dam sites

5. $A$, Rogue River entering the canyon section 12 miles below Grants Pass; B, Rogue River 24 miles below Grants Pass...-

6. $A$, Rogue River looking upstream from Howard Creek; $B$, Rogue River half a mile above Bunker Creek .............

7. $A$, Rogue River in sec. 13, T. 34 S., R. 8 W., half a mile below Almeda; $B$, Rogue River half a mile above Curry-Josephine county line

8. $A$, Canyon in volcanio ash near headwaters of Rogue River; $B$, Crater Lake

9. $A$, Natural bridge formed by lava tube through which Rogue River flows; $B$, Canyon of Rogue River above Prospect.....-

10. $A$, Rogue River above bridge at Prospect; $B$, Mill Creek Falls, Rogue River.

11. $A$, Mouth of Rogue River; $B$, Hamaker reservoir site, Rogue River ..... . . . . . . . . . . .

12. Plan, eross section, and ares and capacity curves, Taylor Creek reservoir site, Rogue River Basin ...................

13. A, Lost Creek dam site, Rogue River Basin; B, Taylor Creek dam site, Rogue River Basin . . . . . .

14. A, Josephine Creek dam site for Kerby Reservoir, on Illinois River, Rogue River Basin; B, Hell Gate dam site, Rogue River Basin. 
Plate 15. A, Lower end of Kerby reservoir site on Illinois River, Rogue River Basin; B, Dam site for reservoir on Applegate River, Rogue River Basin.

Page

16. $A$, Kerby dam site, Illinois River, Rogue River Basin; $B$, Diversion dam of Prospect power plant, Rogue River Basin_-

17. A, Raygold power plant, Rogue River Basin; B, Prospect power house No. 2, Rogue River Basin ................

18. A, Ashland power house, Rogue River Basin; $B$, Rapids on Rogue River above Gold Hill

19. $A$, Dam and pumping plant of Grants Pass Irrigation District at Savage Rapids, Rogue River; $B$, Butte Creek dam site, Rogue River Basin

20. A, Ament Dam, Rogue River above Grants Pass; $B$, Rock Point Dam site, Rogue River Basin; $C$, Trail Creek dam site, Rogue River Basin.

21. A, Horseshoe Bend dam site, Rogue River Basin; B, Rogue River 2 miles above Mule Creek; $C$, Swing Bridge dam site, just below Grave Creek, Rogue River Basin ............

22. Plan, cross section, and area and capacity curves, Copper Canyon power site, Rogue River Basin

23. $A$, Rogue River below the mouth of Stairs Creek; $B$, Mule Creek Canyon, Rogue River, three-quarters of a mile above Stairs Creek

24. $A$, Agricultural land in Rogue River Valley near Illahe; $B$, Illinois River at Fall Creek dam site. . . . . . . . . . . . .

25. A, Copper Canyon dam site, Rogue River Basin; B, Rogue River from Trout Creek.

2. Average daily pumpage of Memphis Artesian Water Department, 1897 to 1928

3. Monthly averages for the period May, 1927, to September, 1929, of the altitude of the water level in the Auction Avenue "wet well" and the Central Avenue well, the pumpage of the Memphis Artesian Water Department from the Wilcox group, the altitude of the Mississippi River at Memphis, and the rainfall at Bolivar, Tenn..............

4. Rise of water level in the Auction Avenue "wet well" with rise in the Mississippi River notwithstanding increase in pump-

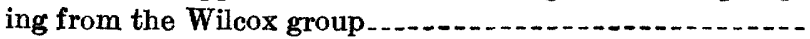

5. Rate of rise of water level on shutting down pumps at the Auction Avenue station on October 25, 1891, and March 6, 1898

6. Profiles of pressure-indicating surface in 1898, 1902, and 1928.

7. Profiles of pressure-indicating surface in 1914 and $1928 \ldots$

8. Plan, cross section, and area and capacity curves, Hamaker reservoir site, Rogue River Basin.......................

9. Plan, cross section, and area and capacity curves, Lost Creek reservoir site, Rogue River Basin

10. Plan, cross seetion, and area and capacity curves, Applegate reservoir site, Rogue River Basin

11. Plan, cross section, and area and capacity curves, Josephine Creek dam site and Kerby reservoir site, Rogue River Basin

12. Plan, Butte Creek dam site. Rogue River Basin........... 
Fradr 13. Plan and cross section, Trail Creek dam site, Rogue River Basin.

14. Plan, cross section, and area and capacity curves, Horseshoe Bend power site, Rogue River Basin.

15. Plan, cross section, and area and capacity curves, Stairs Creek power site, Rogue River Basin.

16. Plan, cross section, and area and capacity curves, Fall Creek power site, Rogue River Basin...............................

17. Plan, Collier Bar dam site, Rogue River Basin.

18. Map of the Colorado River drainage basin, showing sampling points..............

19. Average daily load of dissolved matter carried by the Colo-

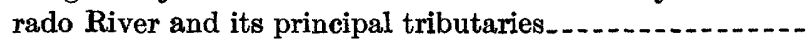





\title{
A PRELIMINARY REPORT ON THE WATER SUPPLY OF MEMPHIS, TENNESSEE
}

\author{
By F. G. Weuls
}

\begin{abstract}
Memphis is located in the part of the Gulf Coastal Plain known as the Mississippi embayment. It is underlain by unconsolidated sand and clay formations of Tertiary and Cretaceous age. The Wilcox group, of Tertiary age, and the Ripley formation, of Cretaceous age, are excellent aquifers, and all the water consumed in Memphis is derived from them. The maximum pumpage from the Wilcox group was reached about 1920 ; in that year an estimated average of $37,575,000$ gallons a day was pumped. In 1928 the average daily pumpage from the Wilcox group was about $33,984,000$ gallons, and in addition to this the Memphis Artesian Water Department pumped an average of $4,616,000$ gallons a day from the Ripley formation.

The static level at Memphis. varies with the pumpage and the stage of the Mississippi River. The original static level was about 235 feet above mean sea level. In 1928 the average static level at the Auction Avenue plant was 202 feet above mean sea level, which was about 33 feet lower than the original level. The yield is therefore about a million gallons a day for each foot of drawdown. The drawdown is not excessive, and additional pumpage can be developed without undue lowering of head.

The water from both the Wilcox group and the Ripley formation is fairly soft and has a moderately low content of dissolved mineral matter. The iron content is sufficiently high to be objectionable, but the iron is easily removed by aeration followed by either settling or filtration for removal of sediment.
\end{abstract}

\section{INTRODUCTION}

On June 1, 1928, field work was started for a report on the groundwater resources of western Tennessee, one of a series to be prepared by the United States Geological Survey and the Tennessee Geological Survey that will treat in a comprehensive way of the water supplies of Tennessee available from wells and springs for muncipal, industrial, and other uses. During the summer and fall of 1928 the field work was completed in 10 counties in the southwestern part of the State, including Shelby County, in which Memphis is situated. It was realized from the beginning that the ground-water conditions at Memphis constituted a very important part of the investigation, and two months was given to the accumulation of data in this city.

Through the cooperation of the Memphis Artesian Water Department it was possible to install automatic water-stage recorders over two representative observation wells, one on Auction Avenúe and one 
on Central Avenue, and thus to obtain for these wells continuous records of the depth to the water level, which show with much precision the relation between the withdrawal of the artesian water and the subterranean inflow of new supplies to recharge the artesian reservoir. It becomes continuously more apparent that any adequate quantitative study of the ground-water supply in an area must be based on data accumulated over a considerable period of time, and that the longer the record the more accurate are the resulting conclusions. Any deduction as to quantity of water made from measurements taken during a brief period are likely to be premature and may lead to erroneous conclusions. For this reason it is planned to continue observations at Memphis for a period of years. The present preliminary report gives the data that have been thus far obtained and such generalizations as can safely be made at this stage of the investigation. A comprehensive report on the groundwater resources of all of western Tennessee is now being prepared for publication.

\section{HISTORY OF ARTESIAN-WATER DEVELOPMENT IN MEMPHIS}

The early history of the development of the municipal water supply in Memphis is given by Lundie ${ }^{1}$ as follows:

Prior to 1870 Memphis relied wholly for its water supply on cisterns and shallow wells.

In 1867-68 an investigation as to a general system of water supply was made by Charles Hermany, C. E., a report on which was presented to the board of commissioners of the city July 15, 1868. In this report $\mathrm{Mr}$. Hermany recommended that a supply be taken from Wolf River near its mouth. This led to the formation of the Memphis Water Co., which in 1870 secured a charter from the State legislature to supply water to the city. The company erected a pumping plant on the south bank of the Wolf River about 2 miles from the center of the city, and laid 17 miles of pipe through which the city was supplied with water pumped from the river. The enterprise was a financial failure, and the plant was sold under foreclosure proceedings in the United States circuit court in December, 1879 , to the reorganized Memphis Water Co. for $\$ 200,000$, the colnpany's statement of cost being $\$ 472,278$.

The yellow-fever scourge in 1878-79 aroused the citizens of Memphis to a thorough sense of the crying demand for improved sanitary conditions, which resulted in the adoption of a sewerage system, the first sections of which were built in 1879-80, under the direction of George $\mathbf{E}$. Waring, jr., C. E. These sewers called for an extension of the water pipes to supply the flushing tanks which are an integral part of the system.

The Memphis Water Co. in May, 1882, concluded a contract with the taxing district of Shelby County (now the city of Memphis) for public water supplythe contract to remain in force for a period of 20 years from May 1, 1882. Rapid extension of the piping system followed this contract.

In 1885 a citizens' movement was instituted with a view toward securing a better water supply, the principal objection to the supply urged at that time

${ }^{1}$ Lundie, John, Report on the waterworks system of Memphis, Tenn., pp. 4-6, 1898. 
being its turbidity. A committee was appointed by the legislative council of the taxing district to investigate and report on the question. Gen. Coiton Greene made a preliminary report to this committee in February, 1866, and in December, 1866, the committee presented its report to the council.

The committee considered three principal sources of supply which seemed available, viz, the Mississippi River, South Horn Lake, and Wolf River at point near the Louisville \& Nashville railroad crossing about 8 miles east of the city. All projects involved methods of filtration.

Prospective supply from wells had been brought to the attention of the committee, but evidence at that time seemed to cast doubt on the practicability of such a system of water supply for city purposes, after the failure of several experimental wells was reported, which had been sunk at the instance of the Memphis Water Co. * * *

While the report of this committee was in preparation, the late Mr. R. C. Graves, then superintendent of the Bohlen-Huse Ice Co., had a well sunk on the company's property on Court Street near the bayou, primarily for the object of obtaining water for condensing purposes, to a depth of $\mathbf{3 5 4}$ feet. After having passed through a stratum of elay 150 feet thick, water-bearing sand-the source of the present supply - was reached, and a flowing well was the result, the water from which rose several feet above the surface of the ground.

A company was organized for the purpose of supplying the city with water from this source, which, after some further experimentation, entered into a contract with the taxing district on July 30, 1887, under the name of the Artesian Water Co., covering terms of public and private supply, and anticipating a consolidation of the interests of this company with those of the Memphis Water Co., then under contract for public supply.

Both water companies then proceeded to sink wells, but consolidation of their interests was consummated in April, 1889, shortly after which the Wolf River Plant was abandoned and dismantled, a temporary station having been erected near the present station (the Auction Avenue station), connecting with such wells as were then operative.

Forty-two wells were drilled during 1888 and 1889 , and the Auction Avenue pumping station was put into operation in 1890 . The Auction Avenue plant consisted of a tunnel 5 feet in diameter and smaller branching tunnels situated 75 to 80 feet below the surface. The wells discharged directly into these tunnels, and the water flowed by gravity to a central suction well at the pumping station, which is locally called the "wet well." Three Worthington vertical compound condensing high-duty pumping engines pumped the water from the central well and delivered it under pressure directly to the service mains.

In 1903 the interest of the Memphis Water Co. was purchased by the city, the Memphis Artesian Water Department was organized; and a Board of Water Commissioners was formed for its supervision.

New wells were drilled from time to time as old wells failed and as additional supplies of water were required, but no change was made in the system until 1907. By this time the Auction Avenue plant had become inadequate, and during 1907 and 1908 a new pumping station was built at Central Avenue. The Central Avenue plant 
consisted of six wells pumped by compressed air and had a capacity of about 5,000,000 gallons in 24 hours.

Prior to 1907 the Artesian Water Department had done some experimenting with segregated pumps. By 1910 the feasibility of these pumps had been demonstrated and several installations were made at different points about the city. Ultimately 14 such installations were available for use. They served to handle peak loads and heavy local drafts.

Realizing that the existing plant was becoming inadequate and that the system was liable to pollution by seepage of sewage into the tunnels, the water commissioners contracted with Chester \& Fleming, hydraulic engineers, in 1919, to make a thorough study of the watersupply system and to submit recommendations for future development. Chester \& Fleming submitted their report in April, 1920. A further study was made by Fuller \& McClintock, hydraulic engineers, who submitted a report to the commissioners in March, 1922. This report considered the various methods of developing a larger water supply and recommended a new plant that would obtain water from wells pumped by compressed air. The recommendations were approved by the water commissioners, and Fuller \& McClintock undertook the construction of the new plant, which was put into operation in 1925.

The present supply is obtained from 23 wells 375 to 550 feet deep and 9 wells about 1,400 feet deep. The wells 375 to 550 feet deep are located at intervals of 500 feet along or near North Parkway and are numbered $\mathrm{C}-1$ to $\mathrm{C}-24$ (see pl. 1); the 1,400-foot wells are at the same well houses as wells $\mathrm{C}-1, \mathrm{C}-2, \mathrm{C}-3, \mathrm{C}-4, \mathrm{C}-5, \mathrm{C}-21, \mathrm{C}-22, \mathrm{C}-23$, and C-24. The wells are pumped by compressed air at a pressure of about 80 pounds to the square inch, which is delivered to the well houses by means of a duplicate system of pipe lines. The water flows by gravity through a duplicate system of mains to the pumping station at North Parkway and Dunlap Street, where it is aerated and filtered and pumped directly into the delivery mains. ${ }^{2}$

The first deep well in Memphis was drilled for the Bohlen-Huse Ice Co., in 1886, but no interest was aroused in the artesian-water supply until another well drilled for the same company in 1887 on Court Street proved to be a flowing -well. Immediately wells were drilled for other industrial plants in Memphis, and Safford ${ }^{3}$ reported 57 wells exceeding 185 feet in depth in the city in May, 1889. Of these wells, 32 were city wells and 25 private wells.

Although no records exist of the number of wells drilled or the quantity of water pumped by private concerns during subsequent years, information gathered from old drillers in the region indicates

I For a detailed description of the city water system see Municipal Engineering, vol. 64, pp. 47-51, 1923.

- Bafford, J. M., The water supply of Memphis: Tenzessee State Board of Health Bull., vol. 5, p. $102,1890$. 
that practically every plant requiring a supply of water of more than 10,000 gallons a day was equipped with its own well. Chester \& Fleming, in their report made in 1920, list 58 private plants having wells with large yields. The writer, in 1928, listed 86 private plants with wells. The location of these wells is shown on Plate 1, and data in regard to them are given in the accompanying table. From the drilling of the first well in Memphis to the present time pumpage from private wells has equaled or exceeded the pumpage of the Memphis Artesian Water Department.

Records of wells of the Memphis Artesian Water Department

[Measurements of depth to water were made on Mar. 15, 1929]

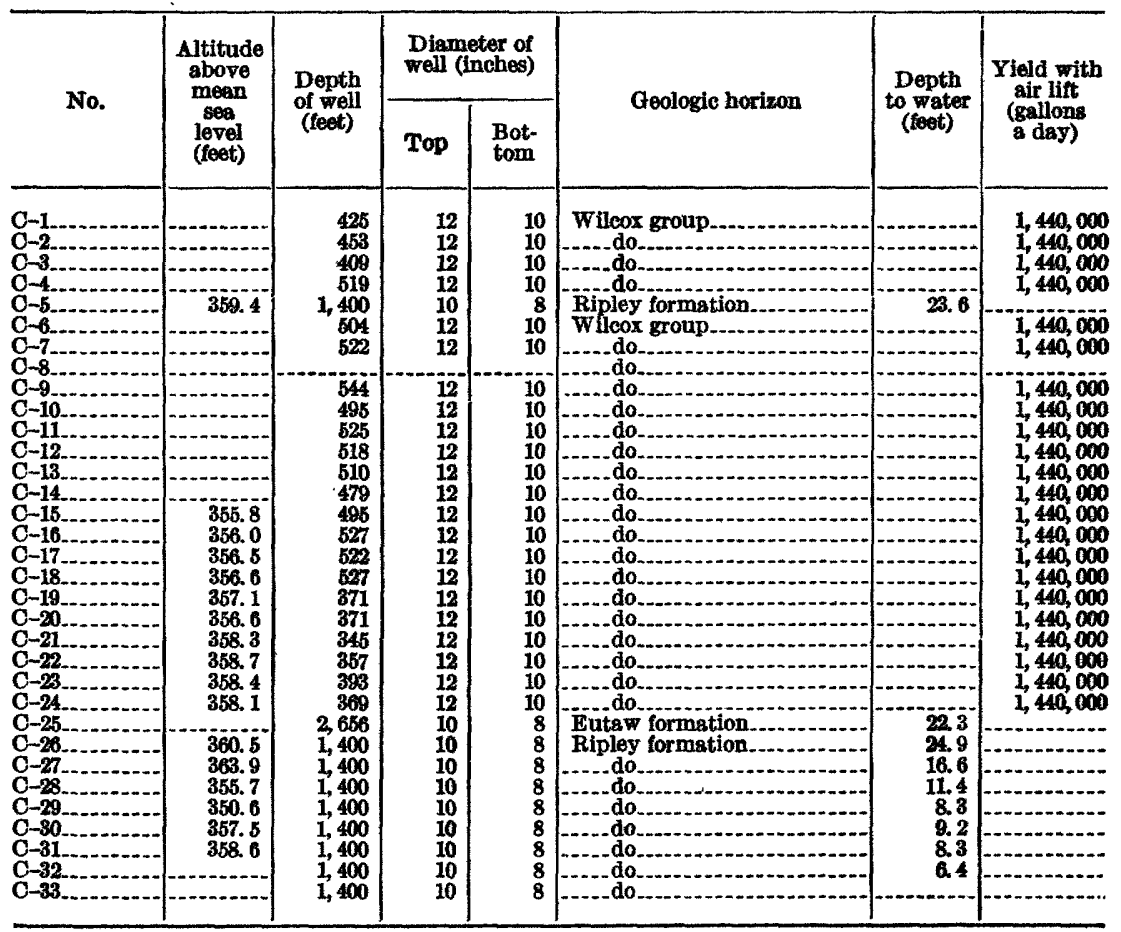




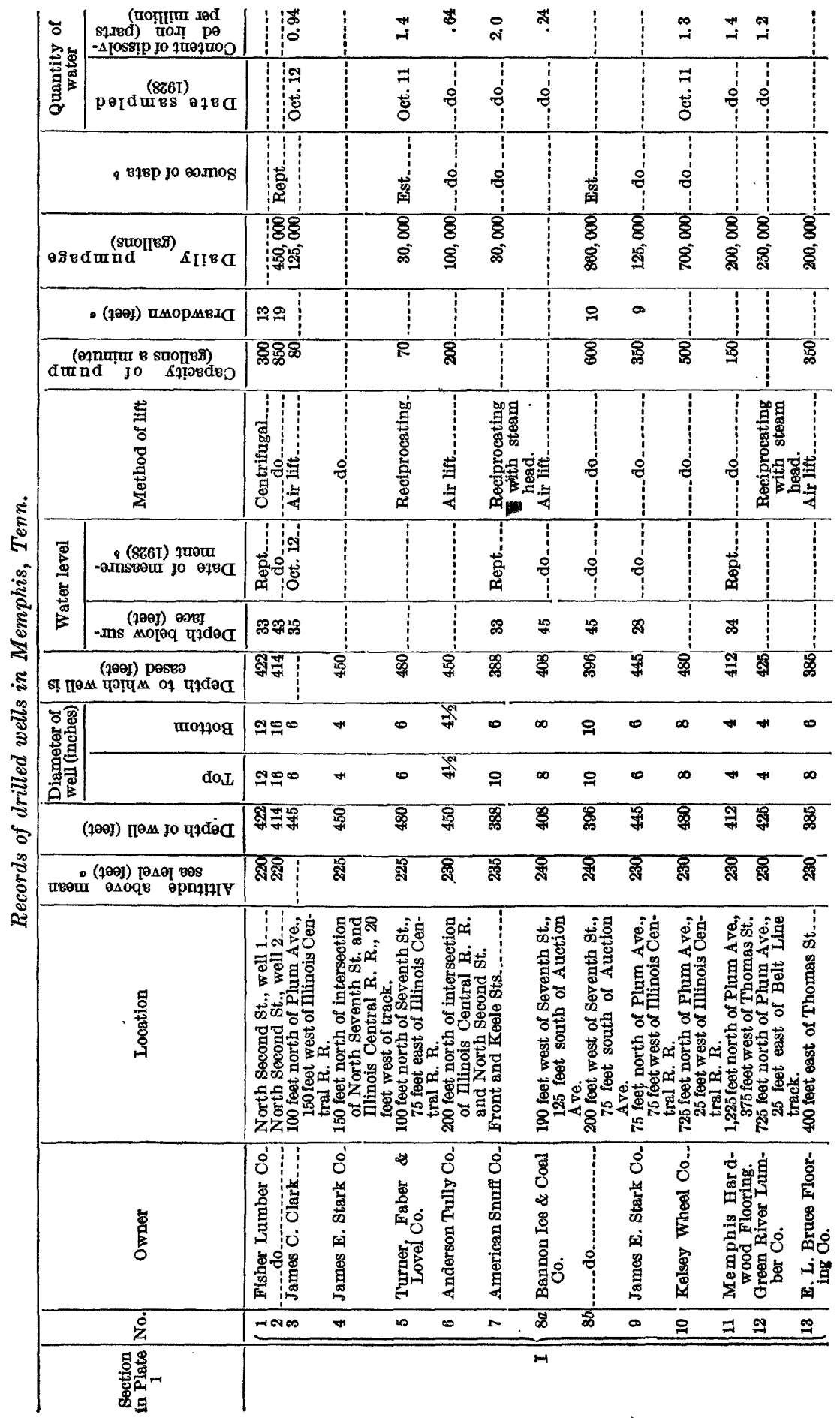


ARTESIAN WATER SUPPLY OF MEMPHIS, TENN.

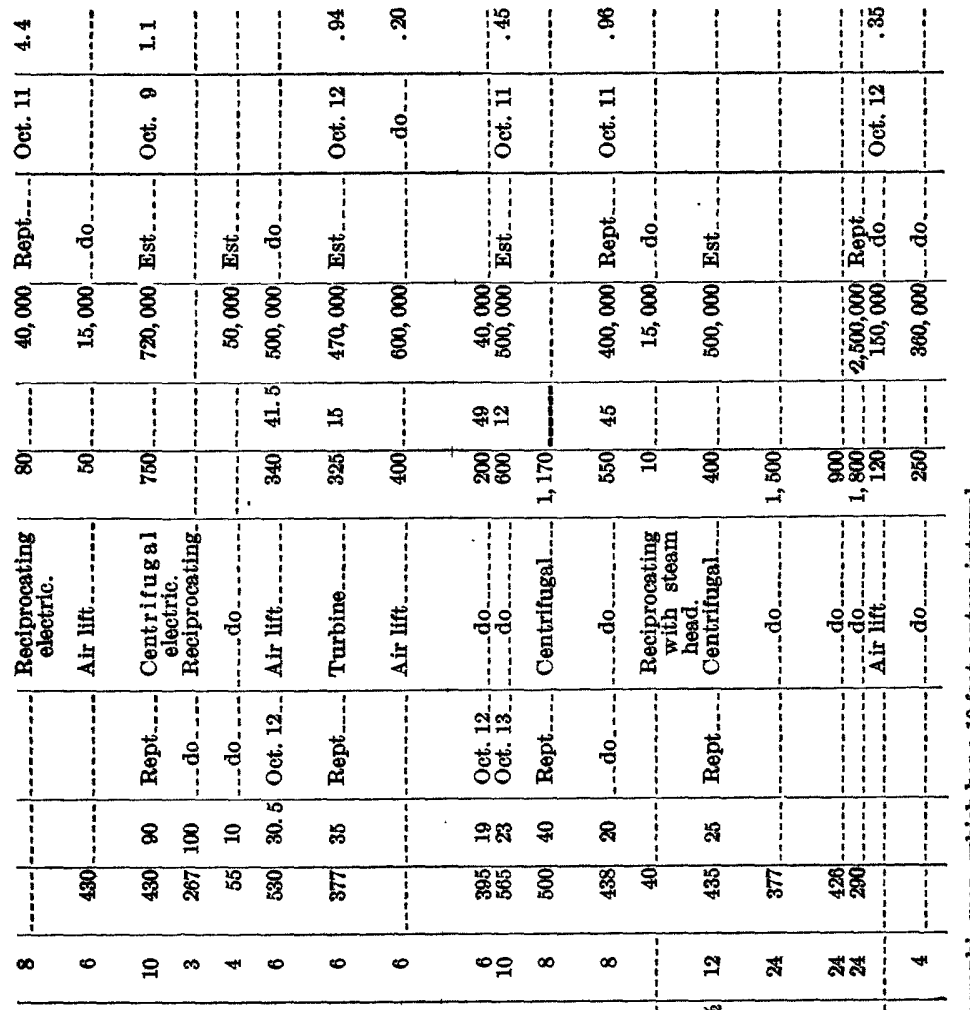

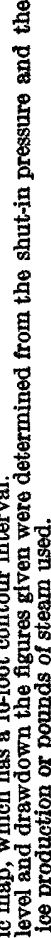

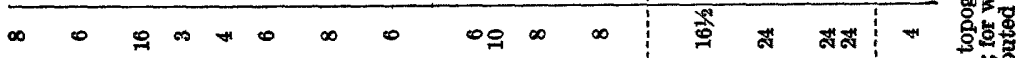

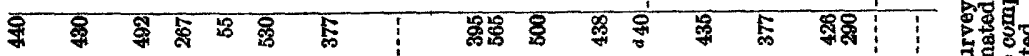

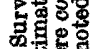

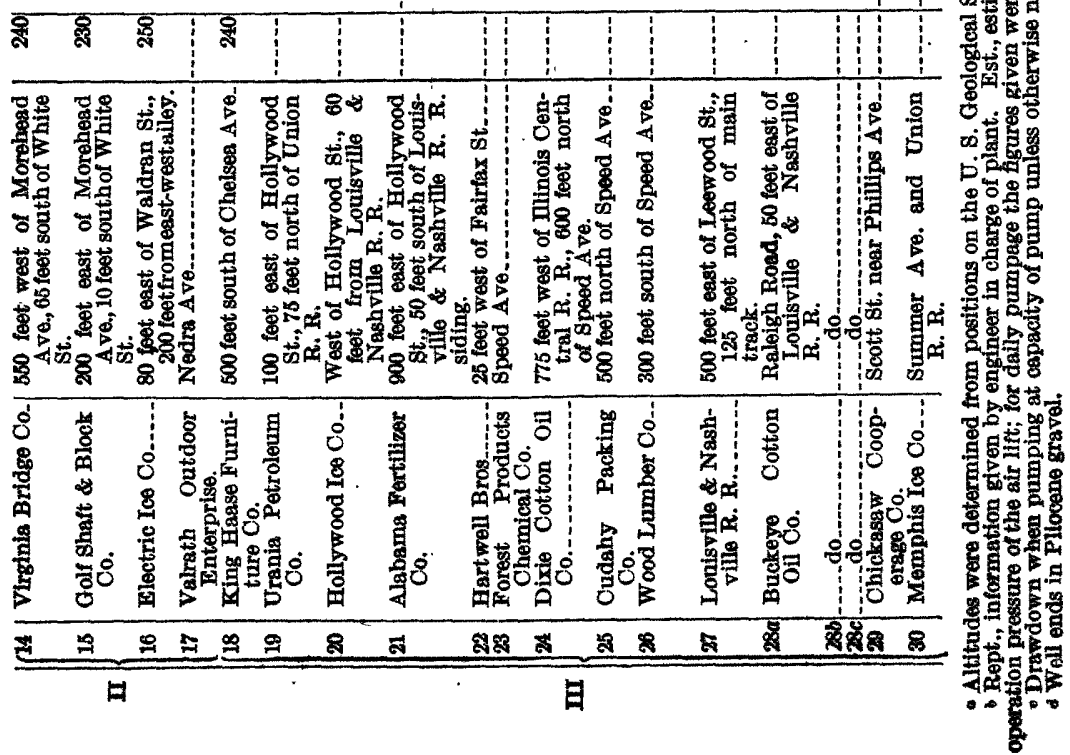




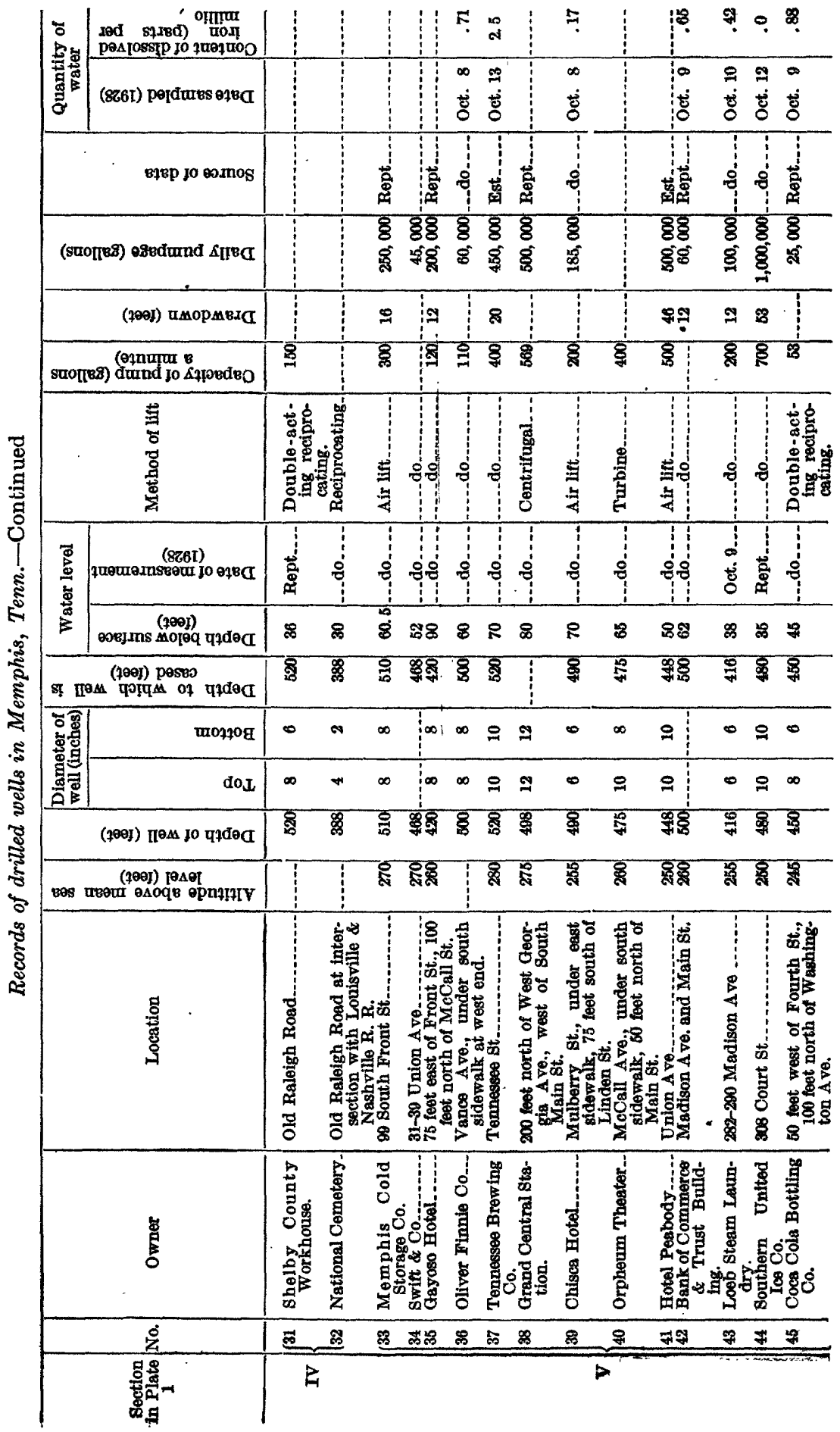


ARTESLAN W ATER BUPPLY OF MOMPHIS, TENN.

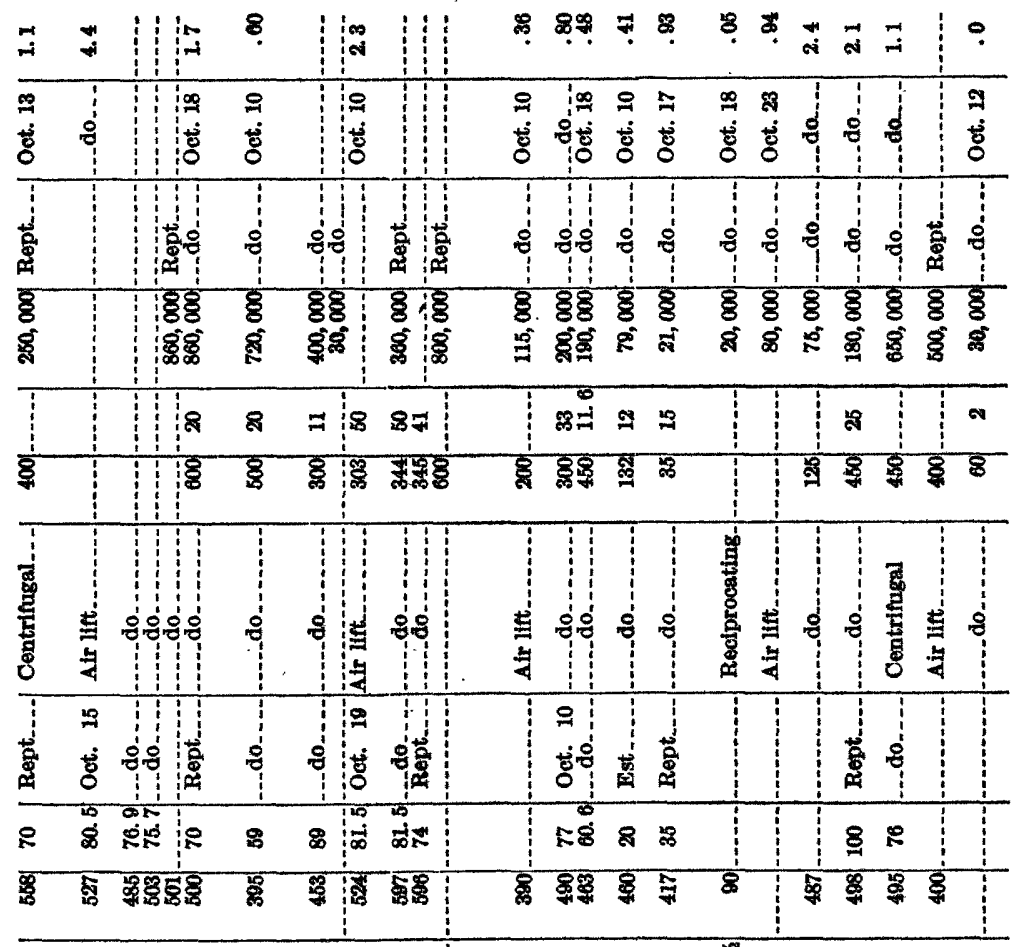

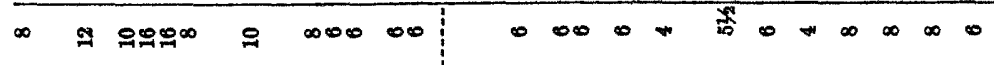

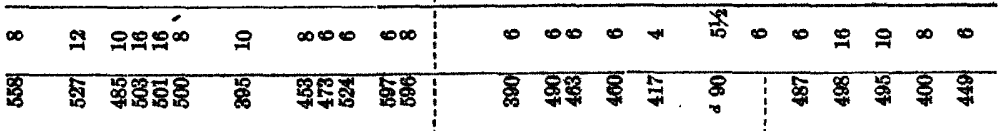

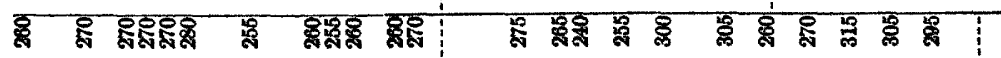

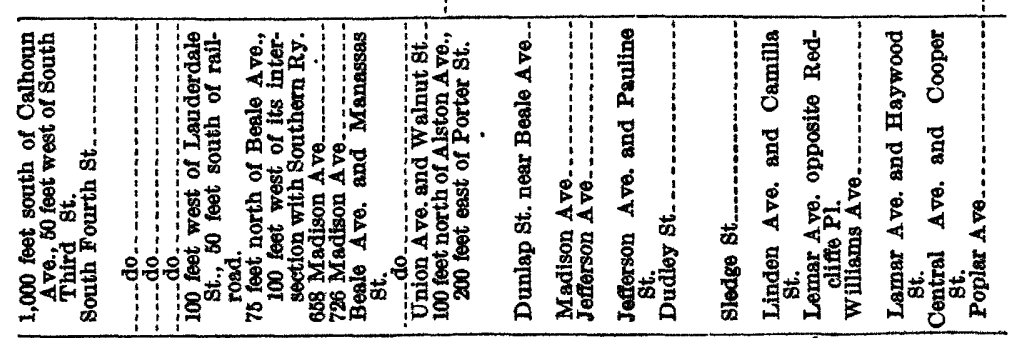

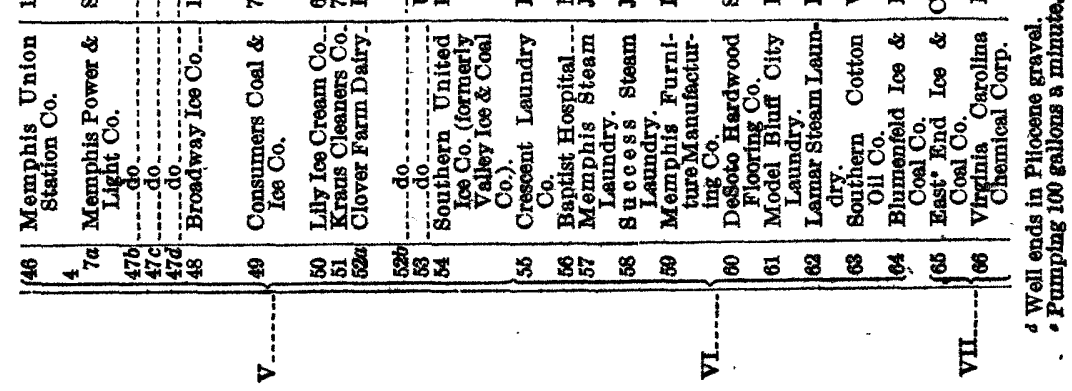




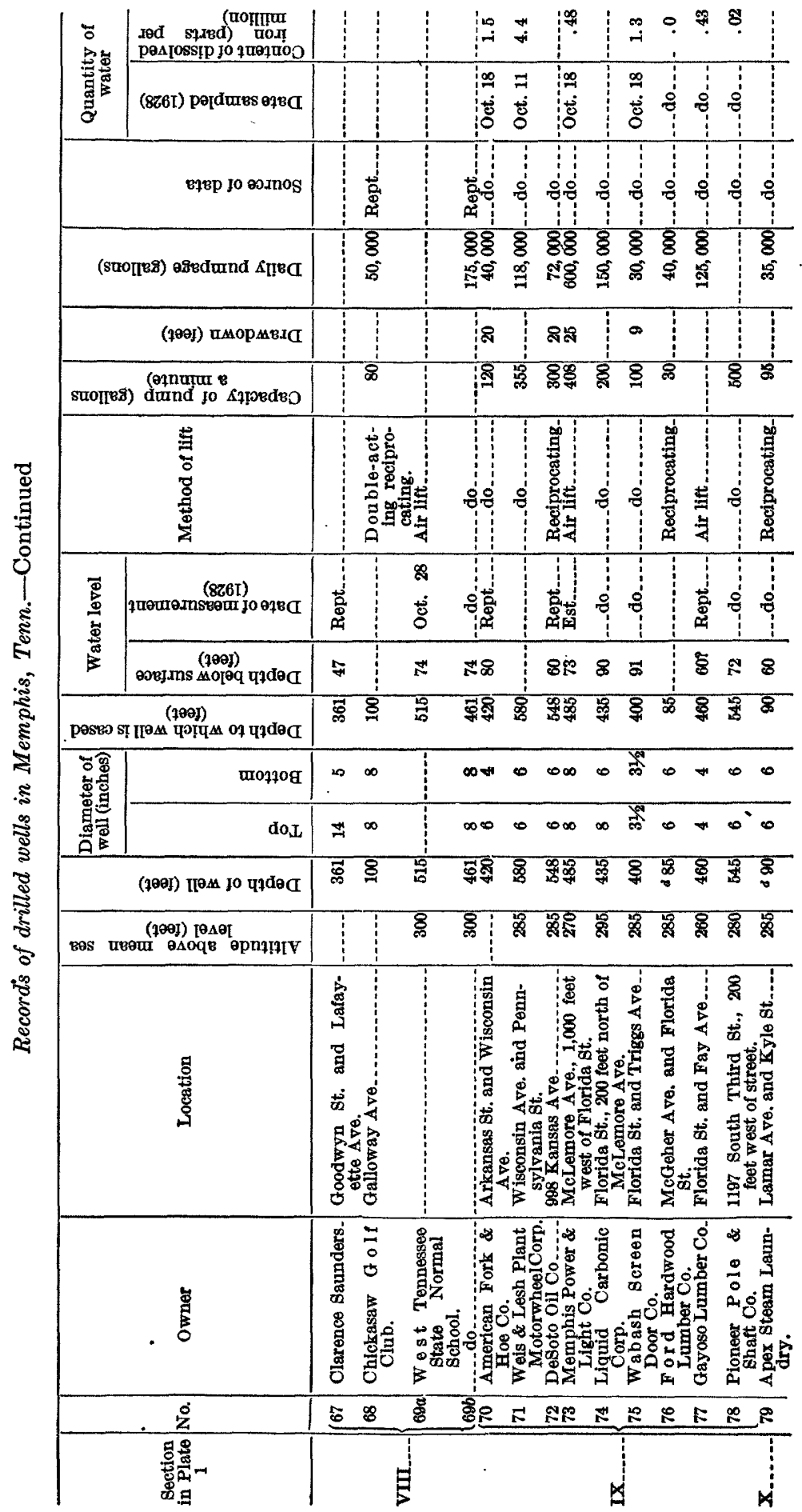




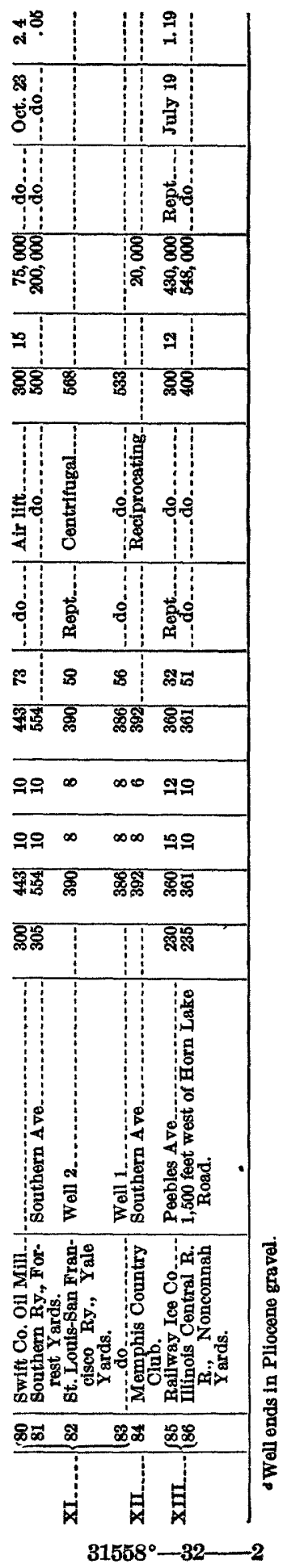




\section{GEOLOGY}

\section{GENGRAL CONDITIONB}

Memphis is situated in what is known geologically as the Mississippi embayment of the Gulf Coastal Plain. This area is underlain by a series of beds of unconsolidated or slightly consolidated gravel, sand, and clay deposited in a broad, shallow syncline, or trough, which pitches gently to the south. The upper end of the trough is in southern Illinois, and its axis lies a few miles west of the Mississippi River; the beds dip toward the axis from both sides. The eastern edge of the syncline almost coincides with the Tennessee River. The east flank has a westward dip of about 30 feet to the mile near its edge, but the dip decreases toward the west. The formations of gravel, sand, and clay range in age from Upper Cretaceous to Recent; they rest on a floor of Paleozoic limestone, shale, and chert. In Tennessee the unconsolidated sediments (Upper Cretaceous and younger formations) are believed to attain about their maximum thickness at Memphis, where they are from 2,700 to 3,000 feet thick. These deposits, named in order from oldest to youngest, are the Tuscaloosa, Eutaw, Selma, and Ripley formations, of Upper Cretaceous age; the Clayton, Porters Creek, Ackerman, Holly Springs, Grenada, and Jackson formations, of Eocene age; Pliocene sand and gravel; and loess and alluvium of Quaternary age. These formations come to the surface east of Memphis. Starting just east of the Tennessee River, in Hardin County, and traveling to Memphis one traverses in succession the outcrops of the different formations, beginning with the oldest, the Tuscaloosa, and ending with the loess, which is the surface formation at Memphis. This is clearly shown in the map and section by Glenn."

A section at Memphis, as determined from well C-25 of the Memphis Artesian Water Department, which was drilled to a depth of 2,656 feet, is shown in Figure 1.

The more important publications treating of the geology of western Tennessee are listed below.

Glenn, L. C., Underground waters of Tennessee and Kentucky west of Tennessee River and of an adjacent area in Illinois: U. S. Geol. Survey Water-Supply Paper 164, 1906.

Wade, Bruce, The geology of Perry County: Tennessee Geol. Burvey, Resources of Tennessee, vol. 4, pp. 150-151, 1914.

Stephenson, L. W., Geology and ground waters of northeastern Arkansas: U. S. Geol. Survey Water-Supply Paper 309, 1916.

Wade, Bruce, The gravels of west Tennessee Valley: Tennessee Geol. Survey, Resources of Tennessee, vol. 7, pp. 55-89, 1917. .

Berry, E. W., Upper Cretaceous floras of the eastern Gulf region in Tennessee, Mississippi, Alabama, and Georgia: U. S. Geol. Survey Prof. Paper 112, 1919.

\footnotetext{
4 Glenn, L. C., Underground waters of Tennessee and Kentucky west of Tennessee River and of an
} adjacent area in Illinois: U.S. Geol. Survey Water-Supply Paper 164, pl. 1 and Fig. 7, 1906. 


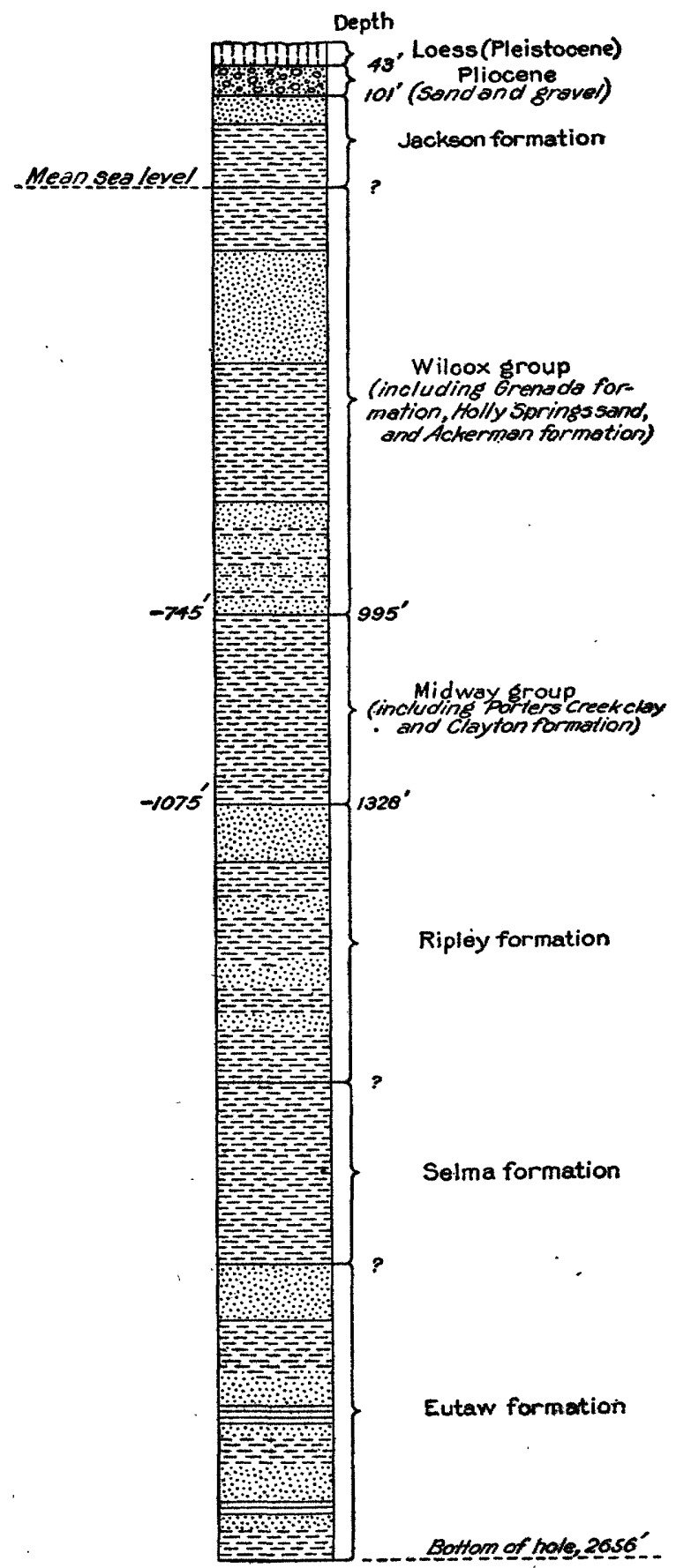


,Roberts, J. K., The Tertiary of west Tennessee: Am. Jour. Sci., 5th ser., vol. 12, pp. 235-243, 1926.

Stephenson, L. W., Logan, W. N., and Waring, G. E., The ground-water resources of Mississippi: U. S. Geol. Survey Water-Supply Paper 576, 1928.

Roberts, J. K., The Tertiary geology and stratigraphy of west Tennessee (manuscript to be published by Tennessee Geol. Survey).

\section{TUSCALOOSA FORMATION}

The Tuscaloosa formation as found in scattered remnants just east of the Tennessee River consists of sandy gravel, but in Alabrma it is variable in character, consisting of gravel, sand, and clay. Berry ${ }^{5}$ shows that the Tuscaloosa formation is a delta deposit and postulates its thinning out or change to massive sediments toward the southwest. The character of the Tuscaloosa at Memphis is not known, as no well there has penetrated the formation, with the possible exception of well C-25, put down by the Memphis Artesian Water Department to a depth of 2,656 feet, the available log of which is not sufficiently detailed to make a positive correlation. To judge from the character of this formation in Alabama, where the conditions of sedimentation were probably more nearly like those at Memphis than those where the Tennessee River outcrops occur, the formation at Memphis is not a gravel deposit but rather a sand or clay. It would probably be encountered at a depth of 2,700 to 3,000 feet.

Though there is no definite information concerning the chemical character of the water from the Tuscaloosa formation at Memphis, owing to the fact that no well penetrates the formation, it seems probable that the water would have a high mineral content. The water from the overlying Eutaw formation contains over 1,500 parts per million of solid matter. In Mississippi analyses of water from the Tuscaloosa formation show increasing mineral content with increasing depth, though it should be noted that the overlying Eutaw formation is more saline than the underlying Tuscaloosa formation. ${ }^{6}$ Without giving a discussion of all the factors in the problem, it seems probable that the fresh water in the Tuscaloosa formation, which, according to the principle of Badon Ghyben and Herzberg, ${ }^{7}$ is in balance with a shorter column of salt water of equal weight, would not reach to a depth of 2,600 feet.

\section{EUTAW FORMATION}

The outcrop area of the Eutaw formation is 85 to 90 miles east of Memphis. Where the Eutaw occurs at the surface it is dominantly

$s$ Berry, E. W., Upper Cretaceous floras of the eastern Gulf region in Tennessee, Mississippi, Alabama, and Georgia: U. S. Geol. Survey Prof. Paper 112, pp. 26-30, 1919.

'Stephenson, L. W., Logan, W. N., and Waring, G. A., The ground-water resources of Mississippi: U. S. Geol. Survey Water-Supply Paper 576, pp. 341-844, 364-365, 1928.

7 Brewn, J. S., A study of coastal ground water, with spectal reference to Connecticut: U. S. Geol. Survey Water-Supply Paper 537, pp. 16-17, fig, 2, 1925. 
sand, although clay is always found with the sand. The most usual condition is a series of rapidly alternating layers of sand and clay, the sand occuring in layers from a quarter of an inch to 6 inches in thickness, interlaminated with sheets of white, gray, or black clay one-sixteenth to half an inch thick. Some of the sand is glauconitic. In some places large lenses of fissile carbonaceous clay are intercalated in the sand. The Eutaw formation has a maximum thickness in its outcrop area of 250 feet. It is probably much thicker at Memphis, but this can not be positively stated. At Memphis the static head of water in the Eutaw formation, as determined in the 2,656-foot well of the Memphis Artesian Water Department, the log of which is shown in Figure 1, is 360 feet above mean sea level. As much of Memphis is below an altitude of 360 feet, water from this formation will overflow at the surface in many places. Water from the Eutaw formation generally contains a large quantity of dissolved mineral matter. At Memphis it contains considerable sodium chloride and is not suitable for domestic or industrial use.

\section{SEIMA FORMATION}

The Selma formation of this region is a sandy or calcareous clay of a slate-blue color. It contains many fossils, some of which are large and conspicuous, such as Inoceramus and Exogyra. This formation is 300 feet thick near its outcrop to the east, but it is probably thicker at Memphis. The depth to the Selma formation at Memphis is not known definitely but is at least 1,800 feet. The Selma is not a water-bearing formation.

\section{RIPLEY FORMATION}

The Ripley formation in southern Tennessee has been divided into three lithologic units-the Coon Creek tongue, the McNairy sand member, and the Owl Creek tongue.

The Coon Creek tongue consists of sandy marl overlain by a series of stratified micaceous clays about 100 feet thick. The Owl Creek tongue is a series of micaceous sands and marls about 50 feet thick. The McNairy sand member as seen in outcrop consists of several hundred feet of medium to fine cross-bedded sands of various colors, including red, white, brown, yellow, and purple. Intercalated with the sands are lenses of clay, which at Memphis probably have considerable horizontal extent and may even be continuous beds. The Coon Creek and Owl Creek tongues are marine phases of the Ripley formation, and at Memphis, which was in the deep part of the embayment, marine conditions may have existed longer than they existed at the locality of the present outcrop of the Ripley formation. This would cause the Coon Creek and Owl Creek deposits to thicken and the McNairy sand member to thin toward Memphis. 
Neither the Coon Creek tongue nor the Owl Creek tongue is a good aquifer. The McNairy sand member includes one bed of good waterbearing sand 100 feet thick, which is known to underlie at least a part of Memphis and furnish a part of the public water supply.

The Ripley formation is 600 feet thick near its outcrop in western Tennessee but may be somewhat thicker at Memphis. At Memphis the top of the formation, as determined in wells $\mathrm{C}-5, \mathrm{C}-25, \mathrm{C}-26$, $\mathrm{C}-27, \mathrm{C}-28, \mathrm{C}-29, \mathrm{C}-30, \mathrm{C}-31, \mathrm{C}-32$, and $\mathrm{C}-33$ of the Memphis Artesian Water Department, is at a depth of about 1,325 feet, or 1,085 feet below mean sea level. The static head of water in the Ripley is about 240 feet with reference to mean sea level.

At present the Ripley formation is being drawn upon only by the Memphis Artesian Water Department, pumping from wells $\mathrm{C}-5$, $\mathrm{C}-26, \mathrm{C}-27, \mathrm{C}-28, \mathrm{C}-29, \mathrm{C}-30, \mathrm{C}-31, \mathrm{C}-32$, and $\mathrm{C}-33$. These wells, which are spaced 500 feet apart, have an average yield of about 800 gallons a minute each and are pumped continuously during the peak period of summer demand in order to lessen the amount of water pumped from the sand between 375 and 550 feet. During the remainder of the year these wells are pumped intermittently. The average daily pumpage from this Ripley sand is shown in Figure 2. From a small initial draft during the last months of 1925 the amount pumped has increased until it attained an average of $4,600,000$ gallons a. day in 1928.

\section{MIDWAT GROUP}

The Clayton, the basal formation of the Midway group, crops out over a very small area in Tennessee. In the southern part of the State it is a poorly consolidated limestone, but toward the north it changes to a glauconitic sand. The nature of the deposit at Memphis is not known.

The Porters Creek is a homogeneous dove-gray to black plastic clay that crops out about 70 miles east of Memphis, but at Memphis it is found 975 to 1,350 feet below the surface, or 750 to 1,085 feet below mean sea level. It is impervious to water and forms an effective confining bed for water in lower formations.

\section{WILCOX GROUP}

The Wilcox group of formations includes, from older to younger, the Ackerman formation, the Holly Springs sand, and the Grenada formation. All the wells in Memphis except the 1,400-foot wells of the Memphis Artesian Water Department obtain water from either the Grenada or the Holly Springs formation, but it is impossible to determine in which of these formations any well ends, because the basis of differentiation is fossil leaves, and these leaves are never present in well drillings.

The Ackerman formation does not crop out in Tennessee, its most northerly exposure occurring in the northwestern part of Tippah 
County, Miss. The contact of the Ackerman formation with the Holly Springs sand probably swings to the northwest and is buried under younger deposits." If this is so the Ackerman formation would be found in depth at Memphis. The formation consists of stratified gray clay that is more or less lignitic. Many of the clay layers are sandy, and some sand beds are interstratified with the clay. The Ackerman formation will yield little if any water.

The Holly Springs formation is predominantly sand; it is strongly cross-bedded and includes material of all sizes from small gravel to the finest of sand, which is in many places mixed with clay. Lenses of clay covering an area of 1 to 8 acres and attaining a thickness as great as 200 feet are found intercalated in the sand in areas where the formation crops out, and similar or larger lenses are undoubtedly present at Memphis. The Holly Springs sand has a maximum thickness of at least 550 feet. The top of the formation is encountered at about 450 feet below the surface, or about 235 feet below mean sea level, and the formation continues to a depth of 1,000 feet, or 785 feet below mean sea level. It is a productive water-bearing formation.

The Grenada formation overlies the Holly Springs sand and is very much like it, but on the whole the sands are finer. The Greneda attains a maximum thickness of 400 feet, and yields large supplies of good water. It extends from about 75 to 450 feet below the surface, or from about 175 feet above to 220 feet below mean sea level. At Memphis several large lenses of blue clay occur near the top of the Grenada formation and serve to form an impermeable layer above the water-bearing sands.

\section{JACKSON FORMATION}

The Jackson formation, which overlies the Grenada, consists of fine sand, clay, and lignite. It contains little water.

\section{PIIOCHNR GRAVRI}

In the vicinity of Memphis the Pliocene deposits consist of coarse sand and gravel. The gravel ranges from pebbles just coarser than grains of sand to cobbles over 51/2 inches in diameter, but the common sizes range from a quarter of an inch to 1 inch. The distribution of the Pliocene gravel is very irregular; in some places the gravel is missing, but in others it attains a maximum thickness of 50 feet. The thick parts of the gravel occur in sinuous bands. The irregularities of distribution may result from the way in which the gravel was deposited or from erosion subsequent to deposition. Where the Pliocene gravel exceeds 20 feet in thickness it is a good water-bearing formation, but water from it is subject to pollution from the surface drainage. 


\section{LOESS}

Overlying the Pliocene gravel and forming the general surface at Memphis is a deposit of loess, a fine-grained; structureless deposit of a light-buff color. It is typically exposed in the bluffs along the river, where it has a thickness of 50 feet. The loess is not a source of water, and shallow wells in the vicinity of Memphis must go as deep as the Pliocene gravel to obtain a supply.

\section{PUMPAGE}

The total pumpage from all the wells in both the Wilcox group and the Ripley formation in 1928 was about $38,600,000$ gallons a day. There is no private pumping from the Ripley formation.

The daily pumpage of the Memphis Artesian Water Department during 1928 showed a maximum of $26,458,000$ gallons in 24 hours, a minimum of $13,429,000$ gallons, and an average of $17,600,000$ gallons. These figures include the pumpage from the 1,400-foot stratum of the Ripley formation, which in 1928 amounted to a maximum of $8,876,000$ gallons a day and an average of $4,616,000$ gallons. The average daily pumpage during 1928 showed an increase of 2,708,000 gallons over the average for 1920 . The population of Memphis in 1928, according to the estimate of the United States Census Bureau, was 190,200 ; the 1920 census gave a population of 162,351 . As calculated from these figures the average daily per capita consumption of city water in 1928 was 92.5 gallons; in $1920,91.7$ gallons. This difference is negligible, the increase in total consumption being about proportional to the growth of population.

The pumpage of the Water Department represents only a part of the pumpage from the Wilcox group of formations in Memphis. Soon after the drilling of the first deep well in Memphis many of the local industrial plants developed private water supplies from deep wells. Owing to the ease of obtaining a good well and the cheapness of operation, private plants, even those with small water consumption, found it most economical to have their own wells. Private wells were in favor also because of the fact that air-lift pumping reduced the iron and carbon dioxide content of the water considerably, and the water so pumped was therefore superior to city water from the Auction Avenue plant. For these reasons virtually all the industrial plants and large buildings had private supplies.

As there are no records of the amount of water pumped by individual concerns in Memphis prior to 1920, it is impossible to determine whether this pumpage has steadily increased, whether it has reached a high point and remained constant, or whether it has reached a maximum and declined. The normal growth of the city would lead to an increase in the private pumpage, which might be assumed to parallel 
the increase in city pumpage. The following factors, however, would tend to decrease the private pumpage:

1. The quality of the water furnished by the city waterworks since 1925 has been greatly improved by effective treatment, so that it is now better than that from wells privately pumped by air lift.

2 . The necessity of renewing wells and pumping machinery has induced many small water consumers to use city water.

3. The need of having a city connection for fire protection involves a minimum fixed charge, and if the amount of water consumed is only slightly greater than that covered by the minimum charge it is not economical to have a private supply.

4. In many small steam-power plants one engineer had charge of both the plant and the pumping machinery. The substitution of electric power in such plants has displaced the engineer, as it is not profitable to employ one simply to supervise the pumps. Centrifugal pumps could be operated by electric motors without much supervision, but owing to the iron content of the water they are not so satisfactory as air lifts.

5. Formerly Memphis manufactured large quantities of ice to be shipped to outlying points, but the development of small, simple machines for producing ice has resulted in the establishment of local ice plants at these points, and the consumption of water in ice plants in Memphis has therefore decreased.

6. The use of spray ponds for cooling condenser water has diminished the amount of water so used. The quantity of water used for condensing by the Memphis Power \& Light Co. (Memphis Electric Co. and Memphis Street Car Co.) has decreased about 10,000,000 gallons per 24 hours since 1920.

It is impossible to evaluate these factors. Factors 2, 3, and 4 represent small water supplies, and the total amount consumed was probably not large; the amount represented by factor 5 may be considerable. The decrease due to the combined influence of factors 1 to 5 probably did not compensate for the normal increase in consumption due to increase of population but only served to lessen the total increase. Factor 6 represents a considerable decrease.

Chester \& Fleming, in their report of 1920, list 58 private plants of large consumption, with an aggregate average daily pumpage of $21,740,000$ gallons. The list of plants was not complete, and $/$ the pumpage given is an estimate, which is, however, sufficiently accurate for the present purpose.

The pumpage of private plants as here used is the estimated daily average for periods during which a plant was running continuously at full capacity. No correction has been made for days or weeks of shutdown or for periods when a plant was running at reduced capacity. 
Therefore, the average given is probably considerably in excess of a daily average determined by dividing the total pumpage throughout the year by 365 . Inasmuch as the estimates of private pumpage are derived by various methods, they are not exact, but any attempt to arrive at an average daily pumpage that would be a true daily average of the pumpage throughout the year would be attempting a precision that the data do not justify. In 1928 the writer listed 86 private plants, with an aggregate average daily pumpage estimated at $21,000,000$ gallons. Although this list did not include every pumped woll in greater Memphis it is believed to include every plant with a pumpage of 50,000 gallons or more in 24 hours. For many of the wells the pumpage is estimated. Of the wells listed in 1920 by Chester \& Fleming, eight with a combined production of 290,000 gallons a day are no longer in operation. Of the wells listed in 1928, six, with a present combined production of $1,255,000$ gallons a day, were in operation in 1920, but were not listed by Chester \& Fleming. A study of 37 plants listed both by Chester \& Fleming and the author shows an increase in pumpage of 32 per cent since 1920. As these plants are distributed among the various industries the increase in pumpage from their wells can be considered representative of the general trend of private pumping, other than the pumping which has been decreased for reasons previously given. On the assumption that there has been an increase of 32 per cent since 1920, the total pumpage in 1920 of the six wells not listed by Chester \& Fleming was 853,000 gallons a day. This increases the estimated total pumpage by private plants in 1920 to $22,593,000$ gallons a day.

The average daily pumpage of the city water supply from the Wilcox group of formations in 1920 was $14,982,000$ gallons a day, which added to the private pumpage of 22,593,000 gallons made the total pumpage from the Wilcox group 37,575,000 gallons a day. In 1928 the city pumpage from the Wilcox group was $12,984,000$ gallons a day, and the pumpage from private wells is estimated at $21,000,000$ gallons a day, making a total of $33,984,000$ gallons a day or 3,591,000 gallons less than in 1920 .

The decrease in pumpage from the Wilcox group from 1920 to 1928 is due to two causes - the developing of wells in the sand of the Ripley formation by the Memphis Artesian Water Department, which began in 1925, and a cut of $10,000,000$ gallons a day by the Memphis Power \& Light Co. during the years 1920 to 1926. In 1928 the Memphis Artesian Water Department was pumping an average of 4,616,000 gallons a day from the Ripley formation. The cut made by the Memphis Power \& Light Co. was effected as follows: The introduction of a spray pond in 1921 cut off $5,000,000$ gallons a day; there was a gradual cut of $2,500,000$ gallons a day in 1924; the shut-down of the Beach Street plant in January, 1926, 
by the Memphis Artesian Water Department, and in succeeding years this pumpage has increased. In the curve indicating the total average daily pumpage from the Wilcox group in the city of Memphis from 1920 to 1928 only two points are definitely known1920 and 1928; the intermediate points were determined by deducting the known cuts in pumpage and distributing the normal increase and new pumpage over the eight years. This curve, therefore, is not accurate, but it shows the general trend of the fluctuations in the total pumpage. The total pumpage from the Wilcox group reached its maximum in 1920, and the pumpage of the Memphis Artesian Water Department from the Wilcox group was also at its maximum in 1920. This is due to two facts - private pumpage, all of which is derived from the Wilcox group, was greater in 1920 than in 1928, and, whereas the total pumpage of the Memphis Artesian Water Department was greater in 1928 than in 1920 , the amount pumped from the Wilcox group was less because an average of $4,616,000$ gallons a day was obtained from the Ripley formation. These two facts should be borne in mind in any studies of the influence of pumping in lowering the water level.

\section{SEASONAL FLUCTUATIONS OF HEAD IN WELIS}

A continuous record of the altitude of the water level in any well will show fluctuations resulting from many causes. In order to determine the nature and magnitude of the fluctuations of the pressure head at Memphis and to deduce their causes, two continuous waterlevel recorders were installed in October, 1928, one in the Auction Avenue "wet well," the other in the Central Avenue well. The level of the water in the Auction Avenue "wet well" represents the static level in about 100 wells, all of which flow into tunnels leading to the "wet well." These wells are scattered over a rectangular area 5,000 by 3,000 feet, which is within 400 feet of the Wolf River at the nearest point and near the center of all pumpage that derives water from the Wilcox group. A record of the altitude of the water level in the Auction Avenue "wet well," taken at 8.30 a. m., has been kept since April, 1927, and the continuous recorder has been operating in the well since October, 1928. The Central Avenue well is at Wills Park, on Central Avenue. It is 4 miles from the river and 2 miles from the nearest pumpingwell of the Memphis Artesian Water Department and is in a section where there is but little private pumping. The record for this well is incomplete.

The data of water level in the Auction Avenue "wet well" and the Central Avenue well are shown graphically in Plate 2. Prior to October, 1928, the level given is the daily reading; after this date the level given is the lowest reading of the 24 hours, midnight to midnight, on the continuous recorders. For comparison, curves showing the 

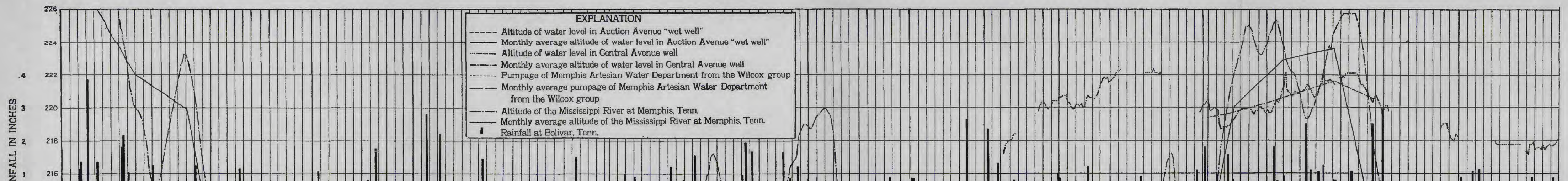

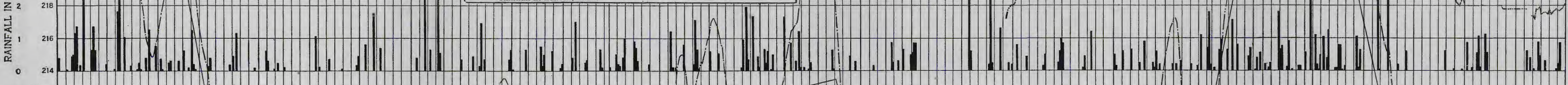

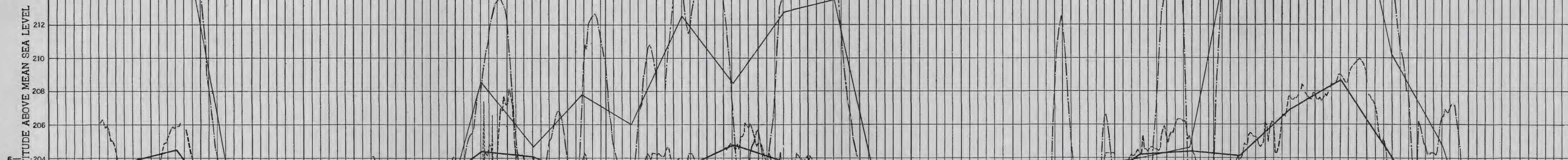
(n) Non

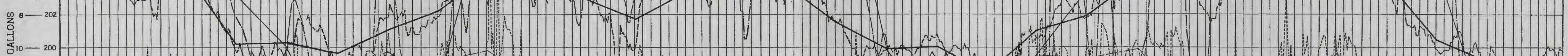

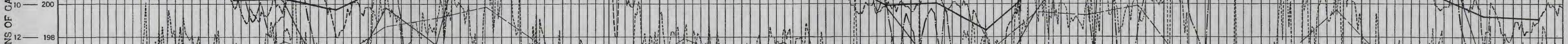

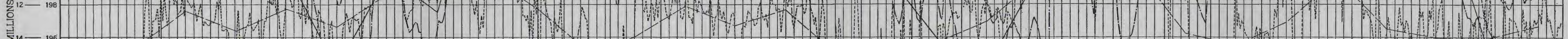

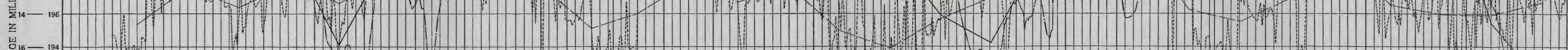

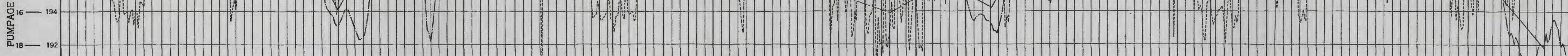

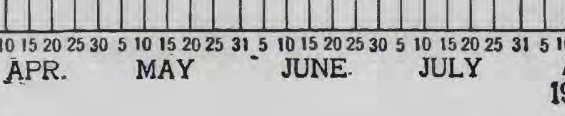


daily pumpage of the Memphis Artesian Water Department from the Wilcox group, the daily altitude of the Mississippi River, and the rainfall are also given. The monthly averages of the altitude of the water level in the two wells, the pumpage, the altitude of the Mississippi River, and the rainfall at Bolivar are given in Figure 3.

The pumpage of the Memphis Artesian Water Department from the Wilcox group is derived by subtracting from the total daily pumpage the pumpage from the Ripley formation. It is plotted in reverse sense-a larger pumpage being lower on the sheet than a small pumpage - in order to facilitate comparison with the water level.

It should be borne in mind that pumpage of the Memphis Artesian Water Department represents only 38 per cent of the total pumpage from the Wilcox group, the remainder being pumped by industrial plants. However, as the factors which necessitate an increase or decrease in the pumpage of the Memphis Artesian Water Department have somewhat similar effects on the industrial pumping, the total pumpage from the Wilcox group roughly parallels the pumpage for the city waterworks with two exceptions. Industrial pumping is cut by at least $3,440,000$ gallons on Sundays in laundries, sawmills, and such plants as completely stop, and it is possible that other plants run at lower capacity, so that the total Sunday cut of industrial pumping is probably in excess of $3,440,000$ gallons. The total pumpage of the Memphis Artesian Water Department shows no such Sunday cut but increases or decreases according to the weather. It is possible for the city to meet changes in the demand by increasing or decreasing the amount taken from the Ripley formation. This is illustrated by the increased pumpage from the Wilcox group during February and March in 1928 and in 1929, which was due to cessation of pumping from the Ripley formation and does not indicate an increase in total pumpage. Any sudden peak in pumpage, such as that for January 16, 1928 , can be accounted for in this way. On the contrary, changes in total pumpage may not show in the graph of the pumpage from the Wilcox group. As a rule, however, the ratio of the pumpage from the Ripley formation to the pumpage from the Wilcox group remains about the same, and it can be assumed that the graph of the pumpage from the Wilcox group represents in a general way the variations of the total pumpage in all Memphis.

The stages of the Mississippi River at Memphis given by the Mississippi River Commission have been used in plotting the altitude of the river.

In plotting the rainfall the records at Bolivar, Tenn., have been used. Bolivar lies almost due east of Memphis in the outcrop area of the Wilcox group. With the exception of local summer rains, precipitation usually occurs over the whole of the outcrop area of the Wilcox group during the same day, so that when it rains at Bolivar rainy weather can be assumed throughout the area. 


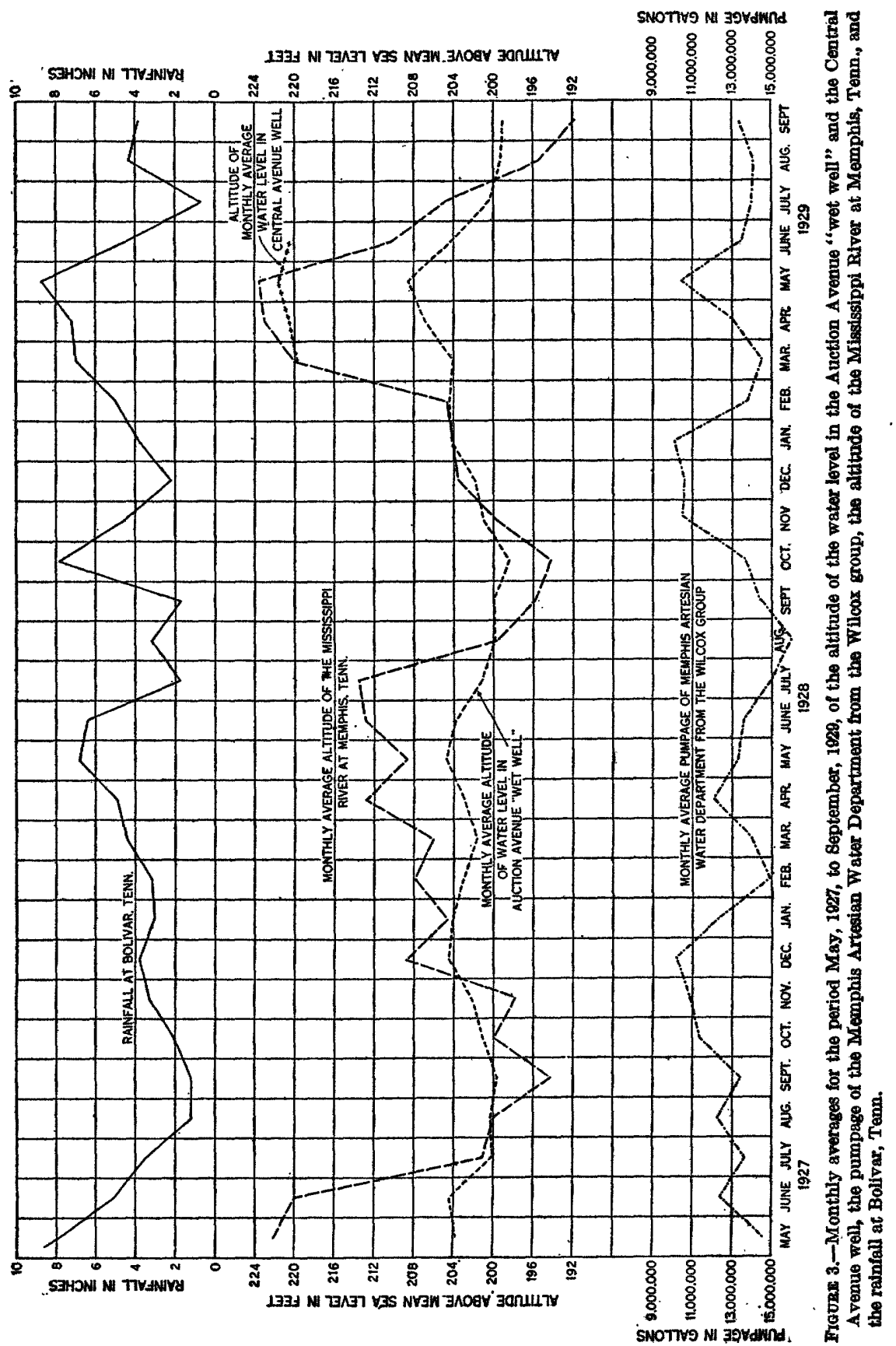


The water level in the Auction Avenue "wet well" attains its highest point early in the summer, either in May or in June. (See pl. 2 and fig. 3.) It drops off rapidly during the summer, reaching the lowest point in September, after which it rises continuously during the fall and early. winter. It may drop a little in February and March before rising to its spring high point. The maximum variation from May 1,1927 , to October 30,1929 , was 13.2 feet. The yearly variation was 8.3 feet May 1, 1927, to May 1, 1928; 7.6 feet May 1; 1928 , to May 1, 1929; and 12.6 feet for the period May 1 to October 1, 1929. The average yearly variation for the $21 / 2$-year period is 9.5 feet. Although the record of water level at the Central Avenue well is incomplete (see pl. 2), it parallels in a general way that of the Auction Avenue well, showing a high in May, after which it drops off rapidly to a low in September and October, and then rises rapidly in the fall and early winter; but unlike that of the Auction Avenue well it reaches its highest point in January.

Pumpage diminishes rapidly from September to December and remains small from January to April, the minimum occurring some time within this period. Pumpage rapidly increases again in May and June and reaches a maximum in August. Thus the time of greatest pumpage and lowest water level in the Auction Avenue "wet well" coincide, but the period of least pumpage and highest water level do not, as can be clearly seen in Figure 3 by comparing the pumpage and water level November, 1928, to February, 1929, with May, 1929. An explanation of this can be found by comparing the water level in the Auction Avenue "wet well" with the altitude of the Mississippi River. The river is at high stages from March until the end of June, the maximum usually occurring in April and May, al though it may occur any time during these four months. The river falls rapidly in July and remains low until October, when it begins to rise. The curve indicating the river stage roughly parallels the waterlevel curve, and the maxima and minima are coincident. Further proof of the influence of the river on the water level is afforded by the record for March 15 to 22, 1929, given in Figure 4. The water level in the Auction Avenue "wet well" continued to rise as the river rose, although the pumpage increased. As there was no rain, the rise of nearly 2 feet in the water level in spite of the increased pumpage can only be attributed to the influence of the rise in the river level. This is shown also by the following table, which gives records for June and August, 1927, and June, 1928. Though the pumpage is nearly the same there is a difference of 4.2 feet in static level. 


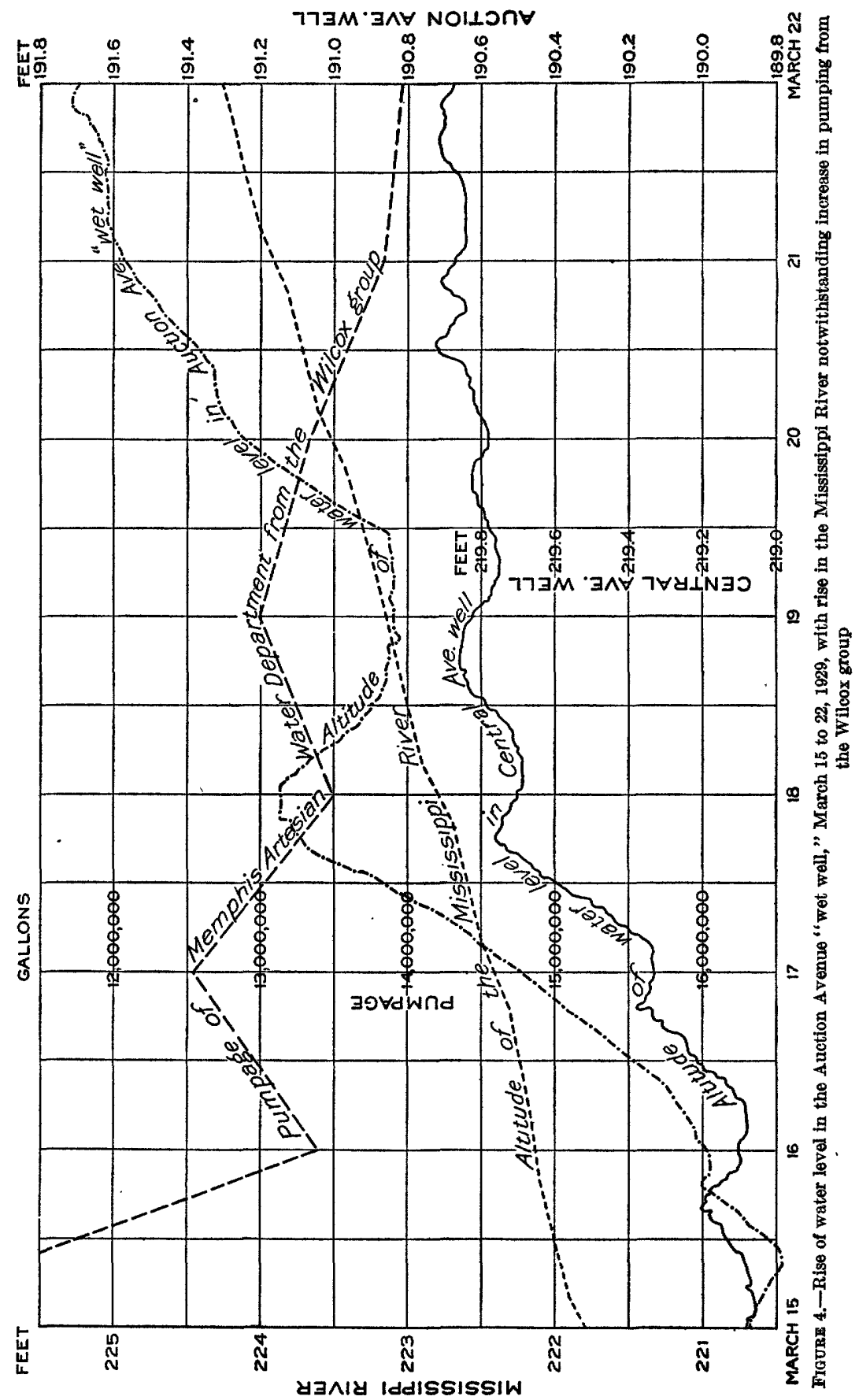


Relation of pumpage and altitude of Mississippi River to water level at Auction Avenue "wet well"

\begin{tabular}{|c|c|c|c|}
\hline Month & $\begin{array}{l}\text { Pumpage } \\
\text { (gallons a } \\
\text { day) }\end{array}$ & $\begin{array}{c}\text { Water } \\
\text { level at } \\
\text { Auction } \\
\text { Avenue } \\
\text { well (feet } \\
\text { above sea } \\
\text { level) }\end{array}$ & $\begin{array}{c}\text { Altitude of } \\
\text { Mississippi } \\
\text { River (feet } \\
\text { above sea } \\
\text { level) }\end{array}$ \\
\hline $\begin{array}{l}\text { June, } 1927 \\
\text { August, } 1927 \\
\text { June, } 1928\end{array}$ & $\begin{array}{l}12,350,000 \\
12,280,000 \\
12,270,000\end{array}$ & $\begin{array}{l}204.5 \\
200.3 \\
203.8\end{array}$ & $\begin{array}{l}220.0 \\
200.1 \\
212.8\end{array}$ \\
\hline
\end{tabular}

The lack of synchronism between the drawdown and pumpage might be attributed to the effect of lag. It has been observed in other artesian areas that the water levels in wells do not respond immedi-

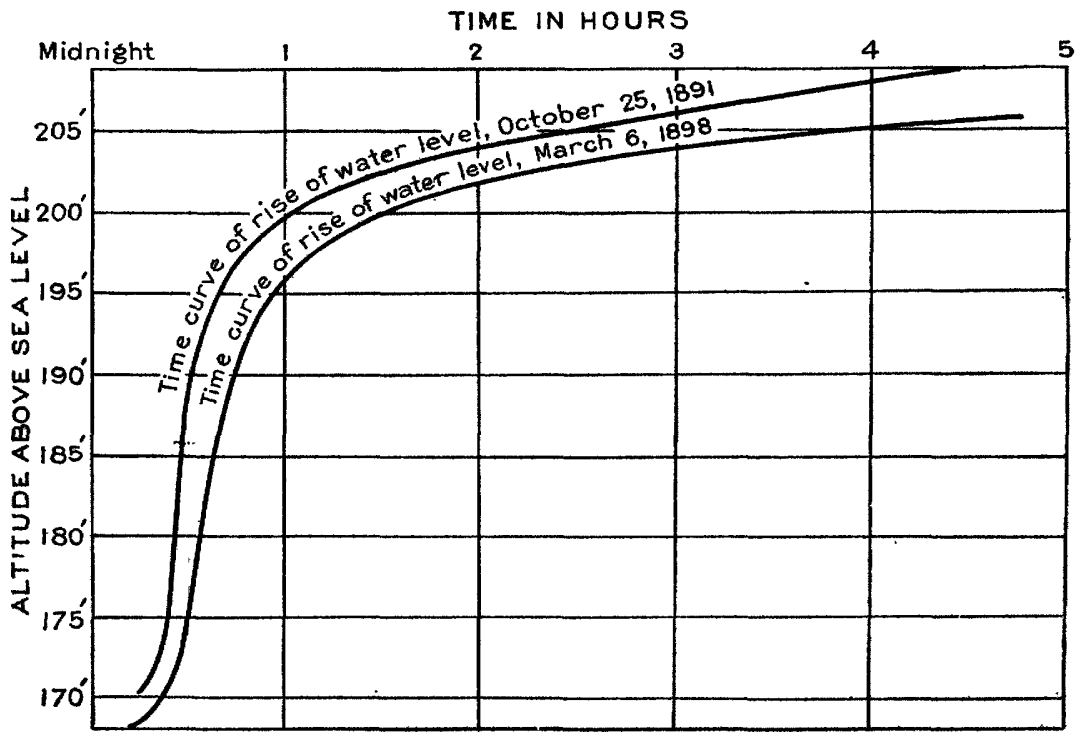

Frgure 5.-Rate of rise of water level on shutting down pumps at the Auction Avenue station on October 25, 1891, and March 6, 1898. (After Lundie)

ately to the starting or stopping of pumpage in adjacent wells but that there is a time interval, or lag, before adjustment takes place. The curves given by Lundie ${ }^{8}$ (see fig. 5) show that when pumpage was stopped at the Auction Avenue plant the recovery of the head was very rapid-for example, in the first hour of shut down on October 25,1891 , the head recovered 30 feet. Chester \& Fleming state that the water level at the Central Avenue pumping station recovered to normal 35 minutes after the cessation of pumping. These facts would indicate that the static head responds very rapidly to changes in pumpage and that the failure of the water level to respond in the cases given can not be explained on the basis of lag. 
Another factor which may influence the water level is the rainfall over the outcrop area of the Wilcox group. A large part of the yearly precipitation occurs from January to June, and the period from July to October is relatively dry. During the growing season most of the precipitation is taken up by the vegetation, and therefore very little of the rainfall reaches the zone of saturation. Hence the period of principal recharge is from November until March, and it may be assumed that in the outcrop area the water level reaches its highest level in the early spring and its lowest in the late summer and early fall. These variations in water level at the outcrop represent variations of load on the confined portion of the water-bearing bed and should cause changes in the artesian head. Data are not available to prove this assumption, and the magnitude of the variations is such that it is possibly concealed by the more prominent factors.

It has been shown that the water level varies with pumpage, river level, and possibly rainfall. The records thus far obtained are so short that it is impossible to determine from them how much each factor contributes to the fluctuations of water level, but it is evident that the major factor is the pumping and that the other factors only modify its effect. In any consideration of drawdown or of specific yield these factors must be borne in mind.

\section{ORIGINAL STATIC LEVEL}

Glenn ${ }^{9}$ gives the original static level at Memphis as 225 feet above mean sea level. Safford ${ }^{10}$ was Glenn's authority, but Safford does not state definitely when the measurement was made, and it is probable that this figure is not the original static level but the level at the time Safford made his investigation, which was after several wells had been drilled. The altitude of the collar of the first successful well is not definitely known. This well was drilled for the Bohlen-Huse Ice Co. in the bayou at Court Street and had a large flow. The bayou is now 230 to 240 feet above sea level, and there is no evidence of filling. Chester \& Fleming state that when the first well at Central Avenue was drilled, in 1908, the water level there from March to May 1908, averaged 232.7 feet above mean sea level. On October 28, 1928, the water level in the well at the West Tennessee State Normal School after a shutdown of 6 hours was 237 feet above mean sea level. This is doubtless less than the original static level in this well, but the West Tennessee State Normal School is $6 \frac{1}{2}$ miles east of the original well on Court Street, and owing to the hydraulic gradient its original static level was probably higher than the original level at Court Street. All

\footnotetext{
9 Glenn, L. C., Underground waters of Tennessee and Kentucky west of Tennessee River and of an adjacent area in Illinois: U. S. Geol. Survey Water-Supply Paper 164, p. 110, 1906.'

10 Safford, J. M., op. cit., p. 102.
} 
these facts indicate that the original static level in the vicinity of the Auction Avenue wells was considerably more than 225 feet, probably about 235 feet.

\section{RELATION OF PUMPAGE TO REGIONAL DRA WDOWN}

The average altitude of the water level at the Auction Avenue plant for the year 1928 was 202.0 feet above mean sea level. This is 33 feet lower than the assumed original 235 feet. Taking 34,000,000 gallons for the average daily pumpage from the Wilcox group in 1928 makes the yield of the formation about $1,000,000$ gallons a day for each foot of drawdown as measured at the Auction Avenue well. This figure for yield must be accepted as only approximate, however, because the original static level is not known exactly, and the water level has a considerable seasonal variation, also because the figure for total pumpage is only an estimate and may be somewhat in error.

If a well in an artesian water-bearing bed is pumped at a given rate, the pressure-indicating surface, as determined by measuring the depth to water at the pumped well and in other wells located in various directions and at various distances from the pumped well, will be found to conform in shape to the surface of a solid of revolution determined by an exponential curve, the vertex of which is at the pumped well. Such a surface is called a cone of depression. A group of closely spaced wells distributed approximately uniformly throughout a circular area and having about the same pumpage can be likened to one well with a pumpage equal to the combined pumpage of the individual wells, and the pressure-indicating surface for such a group of wells is similar in a general way to the cone of depression of a single isolated well. Under most conditions the drawdown, or lowering of the pressure-indicating surface at a pumped well, is directly proportional to the rate of pumping; for instance, if the rate of pumping is doubled the drawdown is doubled. This is also true of the lowering of the pressure-indicating surface at any well in a group of wells, such as that described above, so long as the distribution of the wells remains the same and the rates of pumpage from each remain in the same ratio. If, however, new wells situated at a distance are pumped or if the ratio of pumpage of the wells relative to each other is changed, the drawdown in any well is not proportional to the total pumpage. Without changing the total pumpage, it is possible to change the drawdown in any given well in a group by changing the location of pumpage relative to the well. Also, total pumpage can be changed without changing the drawdown in any given well by changing the location of pumpage relative to the well.

Prior to 1907 most of the pumping in Memphis was concentrated in the down-town section of the city, and the pressure-indicating 
surface was a conelike depression with its apex at the Auction Avenue "wet well." The slope of the cone was steep in the down-town section but was almost flat a short distance away. Increases in pumpage were all in the same area, and the drawdown at the Auction Avenue "wet well" was in general proportional to pumpage. This can be seen by comparing profiles of the water surface in 1898 and 1902 as given by Lundie and Hider. ${ }^{11}$ (See fig. 6.)

In 1907 pumping for the city waterworks was started at the Central Avenue plant, and in 1910 pumping from segregated wells was started. Private pumping showed a similar scattering. The influence of scattering of pumpage on the water level in the Auction Avenue "wet well" can be seen by comparing the figures of pumpage and water level in the following table: Influence of the scattering of pumpage on the water level in the Auction Avenue

\begin{tabular}{|c|c|c|c|}
\hline & \multirow{2}{*}{$\begin{array}{c}\text { A verage } \\
\text { water level } \\
\text { in Auction } \\
\text { Avenue } \\
\text { "wet well" } \\
\text { (feet above } \\
\text { sea level) }\end{array}$} & \multicolumn{2}{|c|}{$\begin{array}{l}\text { Average daiiy pumpage of } \\
\text { Memphis Artesian Water } \\
\text { Department from Wilcox } \\
\text { group (gallons) }\end{array}$} \\
\hline & & $\begin{array}{l}\text { At Auction } \\
\text { Avenue }\end{array}$ & Total \\
\hline $\begin{array}{l}1898 \\
1928 \\
1928\end{array}$ & $\begin{array}{l}175.5 \\
175.7 \\
202.0\end{array}$ & $\begin{array}{l}9,400,000 \\
5,697,000 \\
\text { None. }\end{array}$ & $\begin{array}{r}9,400,000 \\
13,510,000 \\
13,000,000\end{array}$ \\
\hline
\end{tabular}

Thus, though the pumpage has increased, the water level in the Auction Avenue "wet well" has risen, owing to a change in the location of the pumped wells. There has been a lowering of the pressure-indicating surface, however, over the rest of the city, as is clearly shown in Figures 6 and 7.

Further evidence is given in well 172 , in which the water level had an altitude of 208. 5 feet on September 13, 1916, and 204.9 feet on October 30, 1928. Chester \& Fleming state that the wells drilled at Central Avenue in 1908 had water levels at an average altitude of 232.3 feet from March to May, inclusive. The water level in well 157, in the same, location, had an altitude of 226.2 feet on April 10, 1916, and 225.4 feet on June 18, 1916; from March to May, 1929, its average was 220.6 feet.

In considering any figure for drawdown in Memphis such as that given above, or in estimating what effect increased pumpage will have on lowering the water level it should be borne in mind that the lowering of the water level is very largely dependent on the location of the pumpage. By distributing pumping over a large area the

11 Hider, Arthur, Omberg, J. A., jr., and Bell A. T., Engineers' report on the waterworks system of Memphis, Tenn., Memphis, 1904. 


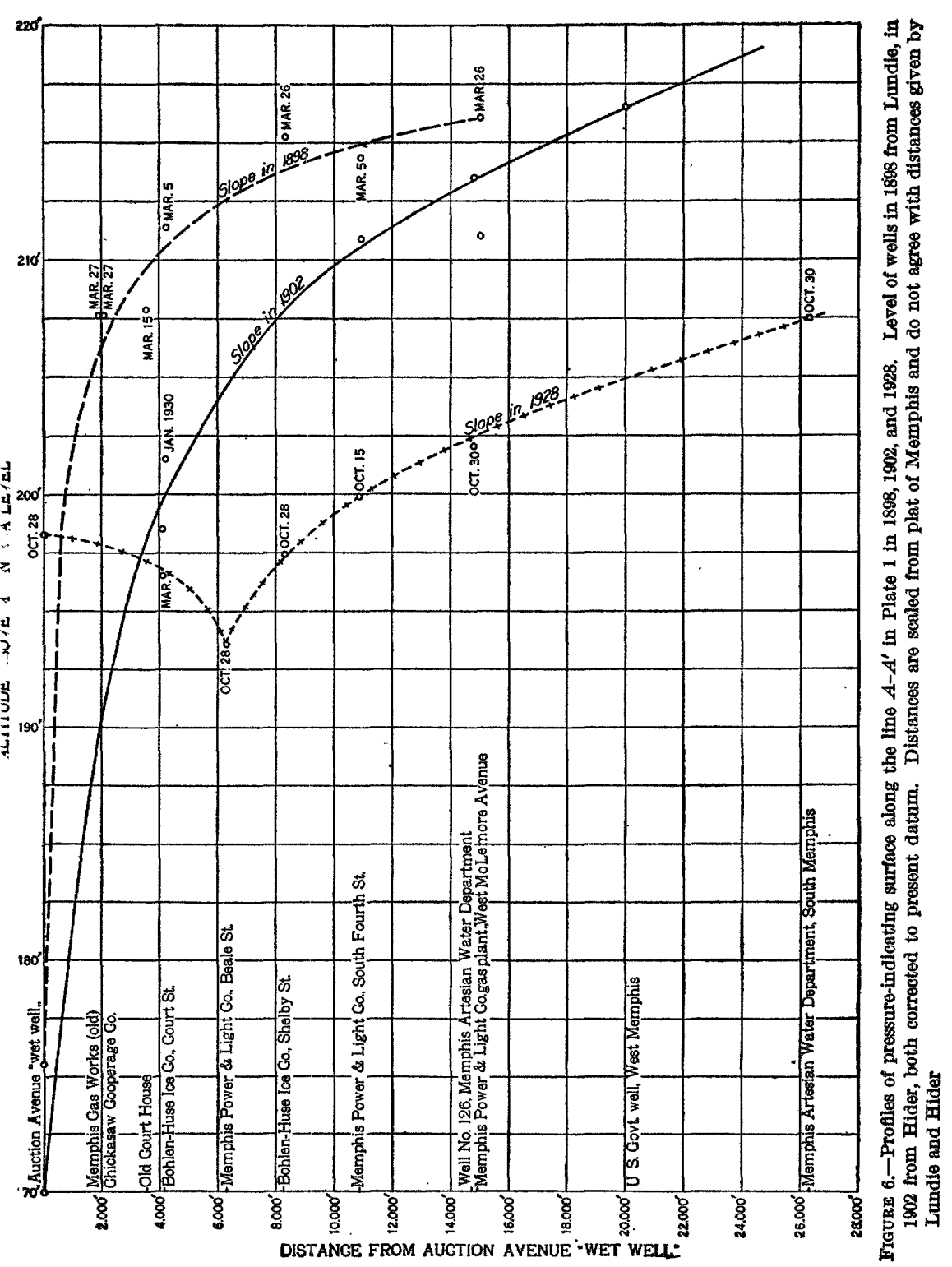


quantity pumped can be greatly increased with only slight lowering of the water level over the whole area.

The pressure-indicating surface has been considerably lowered over a large area, and its lowest point has moved slightly southeast from its former position at the Auction Avenue "wet well," but the maximum drawdown has not increased. The present pressure-indicating surface roughly resembles a trough, the sides and ends of which are determined by parabolas and the bottom of which is a level line. The long axis of the trough parallels the river. The drawdown has increased only slightly since about 1900 . The farther north, south, or east a well is from this axis the bigher is the static level in the well, and the less is the pumping lift. This

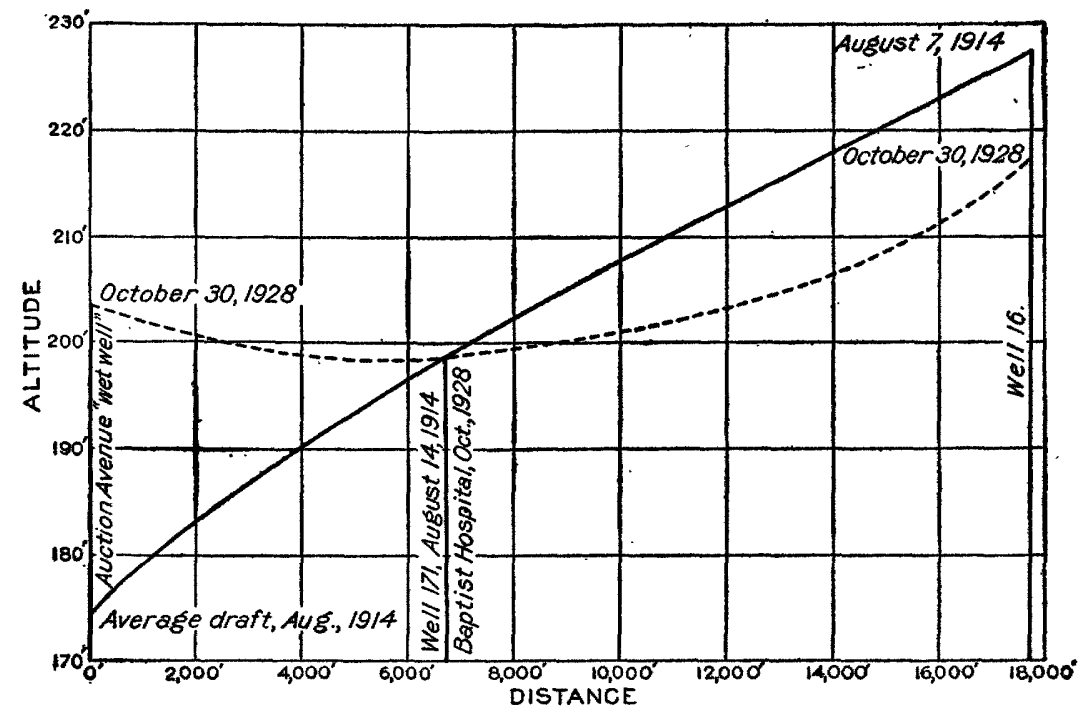

Figdre 7.-Profiles of pressure-indicating surface along the line $B-B^{\prime}$ in Plate 1 in 1914 and 1928

fact shows that a wider distribution of pumping will allow increased pumpage without increasing the pumping lift.

The above discussion of the lowering of the pressure-indicating surface demonstrates that the present pumpage in the city of Memphis can be considerably increased in the outlying areas without materially increasing the drawdown in the down-town area. Also, in view of the large amount of pumping in the city, the drawdown at the Auction Avenue "wet well" is not great, and it is believed that additional supplies can be developed in the down-town part of the area. If more water is pumped the head will doubtless decline, but for any increase anticipated in the immediate future the decline will not be excessive. 


\section{CHEMICAL CHARACTER OF THE WATER}

The analyses in the accompanying table are selected from about 100 analyses of samples collected from wells in southwestern Tennessee in connection with the present investigation. The statements in regard to the waters from the different formations are based on all the analyses, together with others reported in Water-Supply Paper 576 of the United States Geological Survey.

Water from wells in the Wilcox group is in general fairly soft and has a moderately low content of dissolved mineral matter. Analyses 1 and 2 are extremes and 3, 4, and 6 are more typical examples from 21 analyses of samples from wells in the Wilcox group in southwestern Tennessee. Samples were taken from 51 wells in this formation in Memphis and were examined for sulphate and iron to see if any relation could be found between the quantities of these two constituents and the location of the wells with reference to the Mississippi River. No such relation was found. Nearly all the samples had around 5 parts per million of sulphate and 0.4 to 2.5 parts per million of iron. This is considerably more iron than is desirable in a water supply for general use, but the excess is easily removed by aeration followed by filtration.

The water is pumped from many wells by air lift, which accomplishes the necessary aeration while raising the water. Separation of the iron may take place to some extent in the wells, with deposition on the casing. A sample from such a well will show less iron than is present in the water in the ground. Analyses 4 and 5 indicate the improvement in iron content resulting from the treatment of water for the public supply of Memphis. The reduction from 0.61 to 0.08 part per million of iron changes the character of the water completely as regards its appearance on standing and its suitability for laundry use.

Water from the Wilcox group anywhere in Memphis will be approximately the same as that represented by the analyses given.

Waters from the Ripley formation in Tennessee and in Mississippi have a rather wide range in composition. Analyses 7 and 8 are extremes found in southwestern Tennessee. Analysis 9 is about an average water from the formation; it has 124 parts per million of dissolved solids. The average for 27 analyses of waters from the Ripley formation in Georgia was 150, and for 21 analyses from the Ripley formation in Mississippi was 235. Many of the waters from the Ripley formation are soft, like Nos. 8 and 9, and some also contain sodium bicarbonate, like No. 9. Most of the waters from the Ripley formation also carry enough iron to make necessary some form of treatment for its removal.

Except for the slight trouble and expense involved in the removal of the iron, water from either the Wilcox group or the Ripley formation is likely to be thoroughly satisfactory for all ordinary uses. 
Though water from the Eutaw formation in its outcrop area is fairly soft and has a moderately low content of dissolved solids, the water from the Eutaw formation in the 2,656-foot well at Memphis, represented by analysis 10 , is a sodium bicarbonate water containing some chloride. The total dissolved solids amount to 1,466 parts per million. This water contains sufficient dissolved solids to be noticeable to the taste and is unsuitable for domestic or industrial use.

\section{Analyses of ground waters in southwestern Tennessee}

[Parts per million. Samples 1, 2, 4 to 7, and 9 analyzed by Margaret D. Foster, U. S. Geological Survey, Washington, D. C.; samples 3 and 8 by D. F. Farrar, Tennessee Geological Survey, Nashville, Tenn. sample 10, by F. A. Mantel, Memphis Artesian Water Department, Memphis, Tenn. Samples 1 to 6 are from the Wilcox group; samples 7 to 9 from the Ripley formation; sample 10 from the Eutaw formation]

\begin{tabular}{|c|c|c|c|c|c|}
\hline & 1 & 2 & 3 & 4 & 5 \\
\hline 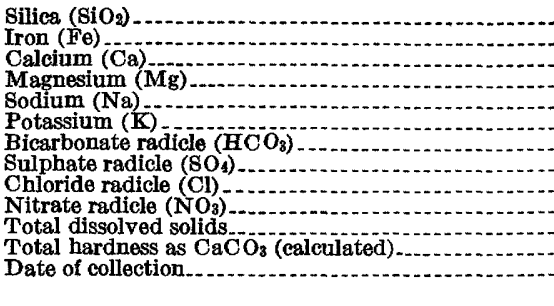 & $\begin{array}{l}19 \\
65 \\
35 \\
15 \\
1.05 \\
387.0 \\
8.6 \\
5.0 \\
333^{.74} \\
306 \\
\text { July } 25 \\
1928\end{array}$ & 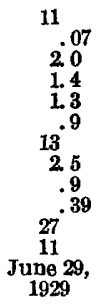 & $\left\{\begin{array}{c}3.0 \\
.1 \\
25 \\
3.0 \\
7.0 \\
86 \\
2.0 \\
12 \\
94^{\circ} \\
75 \\
\text { Feb. } 15 \\
1929\end{array}\right.$ & $\left\{\begin{array}{c}21 \\
11.61 \\
5.5 \\
6.5 \\
1.6 \\
74.6 \\
3.7 \\
1.8 \\
83 \\
50 \\
\text { July } 26 \\
1928\end{array}\right.$ & $\begin{array}{c}16 \\
.08 \\
8.6 \\
4.2 \\
15 \\
1.2 \\
80 \\
4.4 \\
1.8 \\
80^{.07} \\
39 \\
\text { July } 26, \\
1928\end{array}$ \\
\hline & 6 & 7 & 8 & 9 & 10 \\
\hline 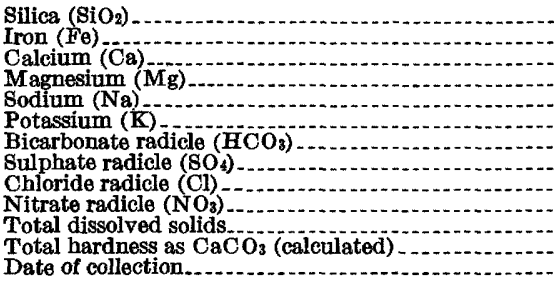 & $\begin{array}{l}13 \\
1.2 \\
15 \\
6.8 \\
6.8 \\
1.6 \\
89 \\
4.0 \\
3.6 \\
91.0 \\
65 \\
\text { July } 19 \\
1928\end{array}$ & $\begin{array}{l}27 \\
40 \\
12 \\
6.6 \\
4.9 \\
137 \\
54 \\
2.7 \\
217^{-0} \\
149 \\
\text { June } 22 \\
1928\end{array}$ & $\begin{array}{c}4.0 \\
.7 \\
7.0 \\
1.0 \\
2.0 \\
17 \\
9.0 \\
.8 \\
1.2 \\
39 \\
22 \\
\operatorname{Mar} .5 \\
1929\end{array}$ & $\left\{\begin{array}{c}20 \\
1.6 \\
3.0 \\
1.0 \\
35 \\
2.7 \\
104 \\
5.5 \\
1.0 \\
124 \\
12 \\
\text { July } 26 \\
1928\end{array}\right.$ & $\begin{array}{r}16 \\
.4 \\
3.2 \\
1.1 \\
432 \\
71 \\
925 \\
1.8 \\
17 \\
1,467.5 \\
15.4 \\
\text { Sept. } 26 \\
1927\end{array}$ \\
\hline
\end{tabular}

1. 250-foot well owned by town of Millington.

2. 335-foot well owned by Kentucky-Tennessee Power \& Light Co., McKenzie.

3. 100-foot well owned by eilty of Covington.

4. 475-foot well, C-3, at southwest corner of pumping station, owned by city of Memphis.

5. Treated water from wells comprising public supply for city of Memphis.

6. 360-foot well, No. 85, owned by Railway Ice Co., Memphis.

7. 230-foot well owned by Hugh Carter, Bolivar.

8. 145-foot well owned by Harris Bros., Luray.

9. 1,400-foot well $C-27$, at southeast corner of pumping station, owned by city of Memphis.

10. 2,656-foot well, C-25, of the Memphis Artesian Water Department, Memphis. 


\title{
WATER-POWER RESOURCES OF THE ROGUE RIVER DRAINAGE BASIN, OREGON
}

\author{
By Benjamin E. Jones, Warren Oakey, and Harold T. Stearns
}

\section{SUMMARY}

The volcano whose crater is now occupied by Crater Lake, in southwestern Oregon, during its last active period poured forth volcanic ash that covered the country within a radius of about 25 miles. Rain and melting snow percolate easily into this light material, but after entering the ground the progress of the water is slow, and several months are required before it reaches the streams. Through the long dry season, therefore, run-off from the rains of the previous winter and spring is appearing in the creeks and rivers to maintain the flow, although there is no precipitation.

The Rogue River drains the western half of this area around Crater Lake. It rises at an altitude of about 5,000 feet and flows in a southwesterly direction for 210 miles to the Pacific Ocean. The drainage area is 5,080 square miles. The upper part of the basin is rough and wooded and has little tillable land. Its annual precipitation is $\mathbf{5 0}$ to $\mathbf{7 5}$ inches. This upper section furnishes practically all of the low-water flow of the river. The middle part of the basin constitutes the agricultural portion. Because of the low rainfall, 20 to 30 inches annually, and its seasonal distribution, very few crops can be raised without irrigation; yet when water is put on the land it is as productive as that in any other part of Oregon. Below the mouth of the Applegate the river enters a more rugged region and flows in a fairly wide canyon containing little marketable timber and practically no tillable land except a few farms below Illahe.

The main tributaries of the Rogue River are the Applegate and Illinois Rivers. The Applegate River drains an agricultural area and during the summer is almost entirely used for irrigation. The Illinois River drains a mountainous area not far from the coast and is used to a slight extent for irrigation above Kerby; below that place it flows in a narrow canyon until it joins the Rogue River. The rainfall in the basin of the Illinois River amounts to about 68 inches, but there is a dry period from June to September, when the flow is very low, for the volcanic ash that acts as a reservoir on the upper Rogue River does not reach to the basin of the Illinois River.

Because of the character of its basin, the large and well-sustained flow, and the steep gradient, the Rogue River is well suited for use as a source of power. Field studies were made by the United States Geological Survey in 1923 and 1926 to determine the amount of power available and its relation to the public lands. Maps and profiles of the river have already been published, and a comprehensive scheme of development is outlined in this report. (See pls. 3 and 4 and Tables 1 and 2.) There are at present (1930) eight constructed power plants in the basin, of which four are on the main stream and four on tributaries. All these sites are capable of further development.

The principal plants are those at Prospect and Raygold, owned by the California-Oregon Power Co. A small plant at Gold Hill is used to pump water for the 
town. At Savage Rapids an irrigation company has erected a dam to raise the water level 20 feet for the double purpose of diverting water directly into a lowlevel canal for irrigation and of supplying power to pump water to a high-level canal. The city of Ashland maintains a small municipal plant on Ashland Creek. The plants on Butte Creek and Mill Creek were erected to supply power to sawmills, and one on Reuben Creek supplies a mine. The information concerning constructed plants in the Rogue River Basin is summarized in Table 1.

Two reservoir sites were found on the Rogue River, one on the Applegate River, and one on the Illinois River. The upper site on the Rogue River is at Haraaker Meadows, in T. 29 S., R. 4 E., where a dam 160 feet high would create 20,000 acre-feet of storage, but the rock of the reservoir site and surrounding country is porous, and a detailed geologic examination is necessary to determine whether or not the reservoir will hold water. The Lost Creek reservoir site on the Rogue River is in T. 33 S., Rs. 1 and 2 E., and has a potential capacity of 110,000 acre-feet with a dam 170 feet high; this reservoir would flood some bottom lands now cultivated and irrigated and would require the moving of a few houses and the relocation of a portion of the Crater Lake Highway. A third possible reservoir site on the Rogue River above Taylor Creek is not considered practicable because of the excessive cost of valuable agricultural land that would be flooded. A reservoir site on the Applegate River in T. 37 S., R. 6 W., has a potential capacity of 195,000 acre-feet with a dam 135 feet high; considerable damage to lands, buildings, and highways would result from its construction. Near Kerby, on the Illinois River, a dam 170 feet high would create a reservoir of more than 400,000 acre-feet capacity; this reservoir site is mostly on private land, but the power plants on the Illinois River below would all be on public land.

The potential power at each proposed power site is summarized in Table 2. The Prospect site, the largest on the upper river, has been considered in connection with the present plant. Most of the sites involve no particular difficulties in construction.

At the Gold Hill site, by building a dam 13 feet high in sec. 11, T. 36 S., R. 3 W., a canal 2.6 miles long, and a penstock half a mile long, a head of 65 feet could be obtained, which would permit the generation of 5,800 horsepower for 90 per cent of the time and 11,400 horsepower for 50 per cent of the time without regulation.

Below Grants Pass there are several good sites where the river flows in narrow rocky canyons. The Taylor Creek site is the first of these. A dam 82 feet high with a crest length of 270 feet at this point would flood only 560 acres of land, most of which lies in the narrow bottom of the canyon. The dam could easily be built to a greater height, but it is doubtful if the increase in head would pay for the agricultural lands overflowed.

At the Swing Bridge site, in T. 34 S., R. 8 W., a dam 107 feet high would have a crest length of 500 feet. The damage to property at this site and the two sites immediately below would be negligible.

At the Horseshoe Bend site, in T. 33 S., R. 9 W., a rock-fill dam 128 feet high is proposed. The spillway would be across the bend.

At the mouth of Stairs Creek, in T. 33 S., R. 10 W., a dam 150 feet high would have a crest length of 320 feet. This is an excellent site for a dam, but it would be difficult to reach with construction materials.

The lowest power site on the Rogue River is at Copper Canyon, where a dam 200 feet high would have a crest length of 550 feet. There would be some property damage due to backwater from this dam, but it would not be excessive The dam site is about 20 miles from Gold Beach, a harbor on the Pacific Ocean, and the construction of a railroad or highway to the site would not be very difficult. 
The value of the power sites on the Illinois River is dependent on the construction of the Kerby Reservoir, and the construction of this reservoir is largely dependent on the amount of damages that must be paid for about 8,400 acres of land that would be overflowed. The land is sandy and of little agricultiural value, and it should be obtainable at a price that would make the project feasible. There are many excellent dam sites below Kerby. In the scheme proposed, besides the dam to create the Kerby Reservoir, a dam 175 feet high would be built at Fall Creek, a dam 190 feet high with half a mile of tunnel at the site above Clear Creek, and a dam 175 feet high with 2.8 miles of tunnel at Bald Mountain. It is estimated that these three projects, together with the Kerby Reservoir and the power that would be generated at the reservoir, would furnish 145,000 continuous horsepower in a year of normal precipitation. Stream-flow records for the Illinois River, however, cover only short periods, and the estimates may be either too high or too low.

The rated capacity of turbines and water wheels installed at the eight constructed plants in the Rogue River Basin is 59,800 horsepower. The total potential power on the Rogue River and the Illinois River amounts to 558,000 horsepower for 50 per cent of the time and 188,000 horsepower for 90 per cent of the time with the natural flow of the stream, and to 575,000 horsepower for 50 per cent of the time and 455,000 horsepower for 90 per cent of the time with the flow regulated by the four proposed reservoirs.

The power available for 50 and 90 per cent of the time under conditions of natural flow as reduced by prospective irrigation demands and the power available after partial regulation by the use of the Hamaker, Lost Creek, Applegate, and Kerby Reservoirs are shown in Table 2. As the lower sections of these reservoirs contain only' a small amount of storage, this portion will be maintained to create a power head. No attempt has been made, however, to estimate the potential power due to the fluctuating head in the reservoirs except at Kerby. The increase from storage in the flow for 90 per cent of the time at Copper.Canyon is due largely to the release of stored water from the Kerby Reservoir, which is used to regulate the flow of the Illinois River. 


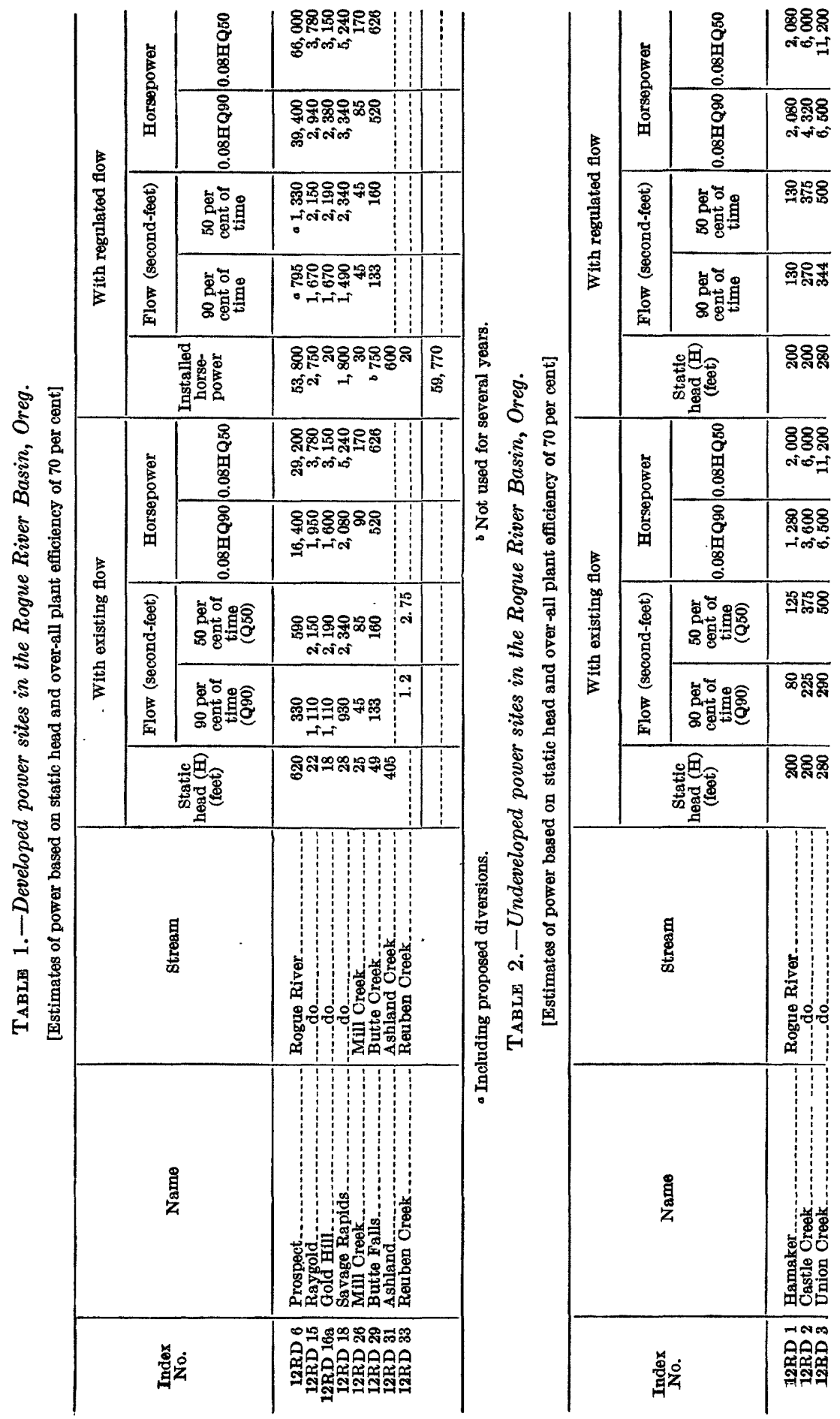


WATER-POWER RHSOURCES OF ROGUE RI VER BASIN, OREGON

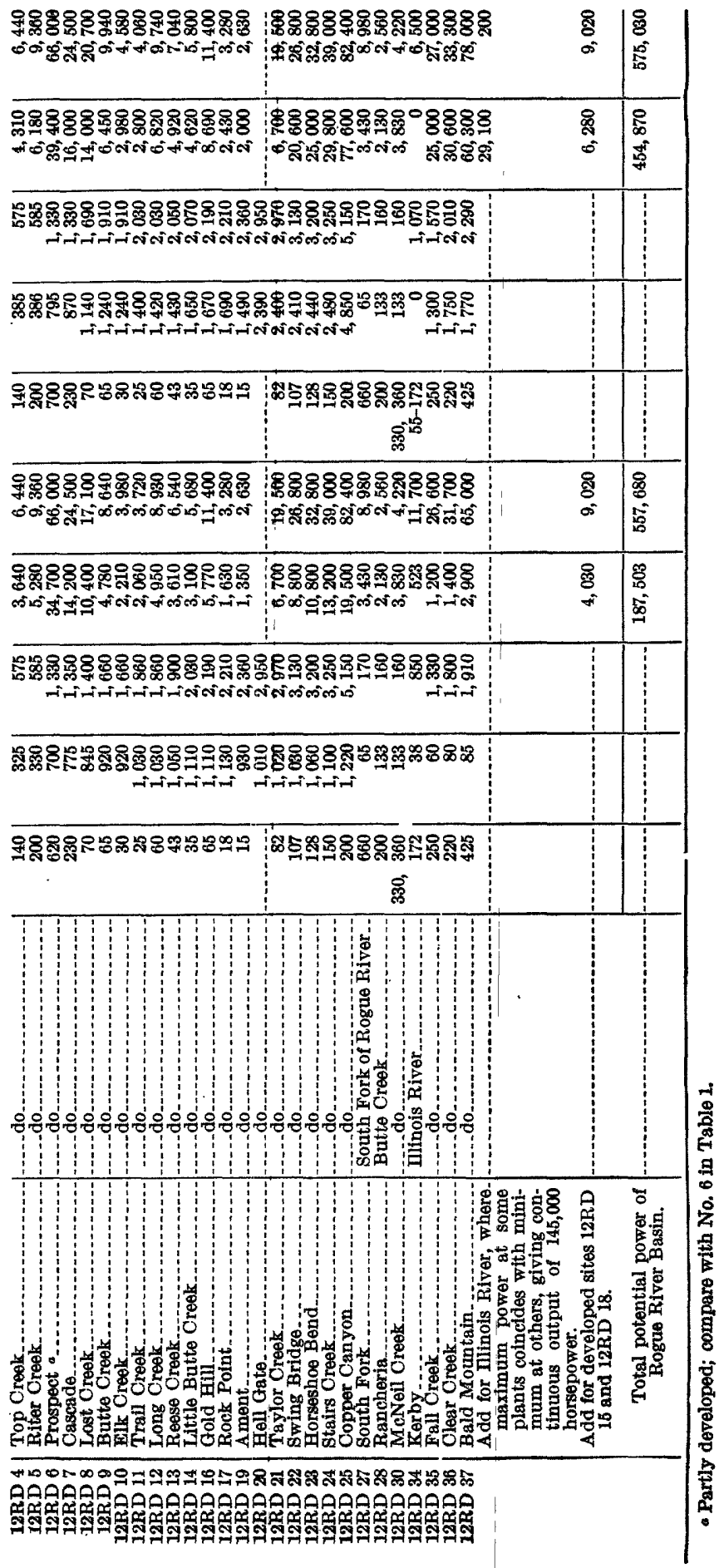




\section{INTRODUCTION}

\section{PURPOSE AND SCOPE OF THE INVESTIGATION}

The Rogue River is well suited to use as a source of power because of the character of its basin, its large and well-sustained flow, and its steep gradient. For this reason the United States Geological Survey made an investigation during the summer of 1923 to determine the amount of power available and to examine the public lands that will be affected by the projects when built.

Benjamin E. Jones and Warren Oakey, hydraulic engineers, of the conservation branch, spent a total of eight months in the field studying conditions along the Rogue River and its tributaries. They selected dam and reservoir sites to be surveyed and were constantly in touch with the three parties sent out by the topographic branch. Maps were prepared covering all those portions of the basin which seemed to possess valuable power possibilities. The Rogue River proper was mapped from a point slightly below its source to tidewater at Gold Beach, and the Illinois River, its main tributary, was mapped from a point 7 miles above Kerby to its junction with the Rogue River. These maps and profiles of the streams have been published in 14 sheets. ${ }^{1}$ Several dam and reservoir sites were surveyed in greater detail and considerable work showing possible diversion projects was done. In 1926 Harold T. Stearns spent about one month in the field studying the geology at the dam and reservoir sites.

From a study of the maps and of conditions on the ground estimates of potential power available in the different sections of the river have been made and a comprehensive scheme of development has been outlined. (See pls. 3 and 4.) The scheme of development followed in actual construction will be determined by the state of the science at the time the development is made and in the light of further detailed surveys and estimates of cost.

\section{ACKNOWLEDGMENTS}

Acknowledgment is due to the California-Oregon Power Co. for furnishing transportation, for the assignment of an engineer to one of the parties, and for general assistance rendered throughout the work. Acknowledgment is also due to the irrigation companies for specific information relative to their projects.

\section{GEOGRAPHY}

The Rogue River Basin (see pl. 3) is shut in by the Umpqua Mountains on the north, the Cascade Mountrins on the east, the Siskiyou Mountains on the south, and the Coast Range on the west. The

1 Plan and profile of Rogue River, Oreg., from mouth to National Creek, South Fork to mile 9, Middle Fork to mile 4, Butte Creek to mile 18, mlinois River to a point 7 miles above Kerby, and minor tributaries. Price, $\$ 1.40$, 
drainage area is 5,080 square miles, practically all of which lies in the southwestern part of Oregon. The river rises on the slope west of Crater Lake at an altitude of about 5,000 feet and flows in a southwesterly direction for 210 miles to the Pacific Ocean. The upper part of the basin is rugged and contains little tillable land. The soil here is porous volcanic ash and pumice, the precipitation is heavy, and there is, in general, a thick forest cover; this part of the basin therefore forms an excellent catehment area. The central part of the basin, from Bear Creek to the Applegate River, constitutes the agricultural portion. Below the mouth of the Applegate River the surface is more rugged and the river flows in a fairly wide canyon almost to Illahe, 7 miles above the mouth of the Illinois River (pls. 5, 6, 7); in this section there is very little timber and practically no tillable land. From Illahe to the mouth of the river the canyon is much wider and there are a few farms.

The main tributaries of the Rogue River are the Applegate and mlinois Rivers. The Applegate River rises in the Siskiyou Range and flows in a northwesterly direction until it reaches the main stream. During the summer it is almost entirely used for irrigation. The Illinois River rises in the same range and flows in the same general direction. Above Kerby it is used to a slight extent for irrigation, but below that place it enters a narrow canyon, in which it flows until it joins the Rogue River at Agness. There is no agricultural land in this canyon, and the timber values are very low.

Mining, both lode and placer, has from time to time been carried on at many points : within the basin of the Illinois River, but at the time of this investigation no active operations were noticed.

The chief agricultural areas are along the Rogue River near Grants Pass, the valley of Bear Creek near Medford, and the valley of the Applegate River. Because of the low rainfall in this part of the basin and its seasonal distribution very few crops can be raised without irrigation, yet when water is put on the land it is as productive as that in any other part of Oregon. The principal crops are orchard products, particularly pears.

The timber resources of the country around Butte Falls, on Butte Creek, are now being developed on a large scale, and this will doubtless contribute considerably to the progress of the district by encouraging the settlement of the agricultural land which is being cleared.

\section{GEOLOGY}

A description of the geology of the numerous reservoir and dam sites involves mention of so many structural features, formations, and types of rocks that a brief summary of the important events in the geologic history of western Oregon and of the areal distribution of the chief formations is given here. 
The known facts in the geologic history of western Oregon before Cretaceous time are few, for the sediments older than Cretaceous have been completely metamorphosed and now occur as schist, slate, and serpentine. These rocks are exposed along the lower part of the Rogue River in Jackson, Josephine, and Curry Counties. Dam sites in these rocks involve no problems of leakage, and all of them are satisfactory for foundations.

Late Jurassic or early Cretaceous time was marked by intrusions of large masses of granodiorite and other igneous rocks and by great movements of the crust. During Cretaceous time the northern and central parts of western Oregon lay below sea level, and in this area were deposited sediments which upon consolidation became conglomerate, shale, and sandstone. These sediments were then subjected to considerable folding, which has altered their original character and tilted the beds at steep angles. Outcrops of these sedimentary rocks are seen along the Illinois and Rogue Rivers in Josephine and Curry Counties. Many of the rugged canyons and consequently the sites of important dams and reservoirs are in the late Jurassic or early Cretaceous intrusive rocks. The granodiorite, diabase, and other intrusive rocks of this period cooled under the weight of overlying sediments, and consequently they do not have the porous structure and leaky contacts and joints that characterize so many of the later extrusive rocks; moreover, in crushing strength most of them are equal to granite, and all are sufficiently strong to support large structures. Generally speaking, these intrusive rocks form excellent sites from the point of view of both the geologist and the engineer, and they are as a whole better than the sites in any of the later formations.

During the Tertiary period numerous changes occurred, chief among which was the building of the Cascade Mountains by uplift and volcanic action. The Eocene, or early part of the Tertiary, was a time of deposition and marine invasion, during which extensive beds of sandstone and conglomerate were deposited. Igneous activity also was intense, for thick dikes and sills of basaltic lava were intruded into the sediments. The sites in the sedimentary rocks of this epoch are generally good, although there may be slight leakage along bedding planes.

During the later half of the Tertiary period marine deposition continued over the northwestern part of the State, interrupted by occasional periods of uplift. None of the dam and reservoir sites are located in the sedimentary rocks of this time. The later Tertiary together with the Pleistocene was a time of greatest volcanic activity. Numerous volcanoes along the Cascade Range poured forth thick flows of lava and emitted showers of pumice; among these was Mount Mazama, whose collapse formed the caldera now occupied by Crater Lake. (See pl. 8, B). Many of the lava flows coursed down river 
valleys and partly filled them. Since that time the rivers have excavated portions of the lava fills and formed narrow canyons with vertical walls of lava, in which are many rapids and waterfalls. (See pls. $9, B$, and 10 ).

The Rogue River Valley, as shown by the terraces at the Hamaker and Lost Creek sites, has had a long and complicated geologic history. The ancestral valley at the Lost Creek site had about the same width as the present valley: but was not so deep. During the Pliocene epoch numerous eruptions of basalt occurred from vents on the upper slopes of Mount Mazama. This lava was very fluid; it flowed down the Rogue River Valley for many miles and accumulated to a depth of about 200 feet. In reestablishing its course the river naturally sought the lowest places in the lava fill. Many of these places were at the contact of the lava with the old valley wall; consequently the river renewed its work of cutting at one side of its ancient canyon and carved a new canyon with the rocks of the old valley wall on one side and the rocks of the new lava fill on the other. In some places its new course did not coincide with the old one, and long stretches of the old river channel, either to the right or left of the present channel, remain buried under hundreds of feet of lava. The remnants of the lava fill or intracanyon flows now form high flat-topped benches along the river. A very conspicuous one is crossed by the new Crater Lake Highway at the site of the canal of the Prospect power plant. Near this place the Rogue River leaves the top of the intracanyon lava and enters a deep valley at the edge of the lava fill. The bench that lies 220 feet above the south side of the river in the N. 1/2 sec. 25, T. 33 S., R. 1 E., is a remnant of this intracanyon lava fill. The road from McLeod Bridge up the east side of the Rogue River follows along the top of this bench for several miles. This remnant of the intracanyon lava occupies a critical position in the success of the Lost Creek site and is discussed further on page 76.

Most of the intracanyon lava is fractured and fissured, and at many places it covers ancient gravel beds through which impounded water might escape rapidly.

Pumice deposits cover wide areas, especially in the vicinity of Crater Lake and in the upper part of the Rogue River Valley. (See pl. $8, A$.) After the Rogue River had carved out a wide valley in the intracanyon lava and had reached approximately its present stage, a gigantic mud flow came down the valley during one of the great explosive eruptions of Mount Mazama, probably not long before the collapse of the volcano. This mud flow consists almost entirely of ash and pumice boulders.

Accompanying explosive volcanic eruptions there are generally torrential downpours resulting from the condensation of volcanic steam and from meteoric storms, but because of the great thickness of light 
volcanic ash and pumice deposited, the streams become choked and soon either stop flowing or flow as a pasty mud. Thus each valley becomes filled, sometimes to overflowing, with the pasty ash and pumice. During the eruption of Mount Mazama the streams poured their pumiceous mud into the master stream-the Rogue River-where its accumulation formed a mud flow about 200 feet thick, which moved many miles down the valley. As the deposit was only slightly consolidated the river soon carved a new valley in it, leaving terraces along the valley wall at the Hamaker site and elsewhere.

Dam sites in the intracanyon lava and pumice may be excellent so far as purely physical form is considered, but the porous nature of the rock, the misplaced drainage, and concealed river channels (see pl. 9, A) make them treacherous for storing water because of possible leakage.

During Pleistocene time the high peaks of the Cascade Range were covered with glaciers, which moved down the valleys of most of the larger streams. While these glaciers existed the master streams were overloaded with débris and aggraded their valleys. Later erosion excavated valleys in the glacial fill, leaving the remnants as gravel terraces. Some of the dam sites are located in this material and are consequently poor because of the amount of excavation necessary to reach bedrock.

\section{CIMATE}

The Rogue River Basin is surrounded by mountains that range in height from about 3,000 feet to over 8,000 feet, increasing gradually as the eastern limit of the basin is approached. The following table giving the mean monthly and mean annual temperature at several points in the basin, listed in order from east to west, shows how the temperature varies with the altitude and with the distance from the sea.

TABLE 3.-Mean monthly and yearly temperature $\left({ }^{\circ} F.\right)$ in the Rogue River Basin, Oreg.

\begin{tabular}{|c|c|c|c|c|c|}
\hline Month & $\begin{array}{l}\text { Crater } \\
\text { Lake }\end{array}$ & Prospect & Medford & $\begin{array}{l}\text { Grants } \\
\text { Pass }\end{array}$ & $\begin{array}{c}\text { Gold } \\
\text { Beach }\end{array}$ \\
\hline $\begin{array}{l}\text { January } \\
\text { February } \\
\text { March } \\
\text { April } \\
\text { May- } \\
\text { June- } \\
\text { Augyust } \\
\text { Auptember } \\
\text { October } \\
\text { November- } \\
\text { December }\end{array}$ & $\begin{array}{l}24.5 \\
27.7 \\
32.1 \\
36.6 \\
41.6 \\
47.7 \\
55.6 \\
54.7 \\
47.4 \\
33.3 \\
31.0 \\
25.0\end{array}$ & $\begin{array}{l}34.8 \\
38.0 \\
42.4 \\
46.9 \\
55.9 \\
58.0 \\
65.9 \\
65.0 \\
57.7 \\
44.6 \\
41.3 \\
35.3\end{array}$ & $\begin{array}{l}37.8 \\
41.8 \\
46.1 \\
50.9 \\
56.6 \\
64.8 \\
71.6 \\
70.9 \\
63.3 \\
52.9 \\
43.4 \\
37.1\end{array}$ & $\begin{array}{l}39.1 \\
42.5 \\
46.6 \\
51.3 \\
56.8 \\
62.6 \\
69.6 \\
68.9 \\
61.9 \\
55.6 \\
44.5 \\
39.1\end{array}$ & $\begin{array}{l}44.6 \\
45.0 \\
46.7 \\
40.6 \\
51.5 \\
55.2 \\
57.6 \\
59.2 \\
57.8 \\
6.2 \\
40.6 \\
46.9\end{array}$ \\
\hline $\begin{array}{r}\text { Yearly mean } \\
\text { Altitude }\end{array}$ & $\begin{aligned} 38.6 \\
6,016\end{aligned}$ & 2.800 & $\begin{aligned} 53.1 \\
1,425\end{aligned}$ & $\begin{array}{r}53.0 \\
940\end{array}$ & $\begin{array}{r}51.6 \\
40\end{array}$ \\
\hline
\end{tabular}




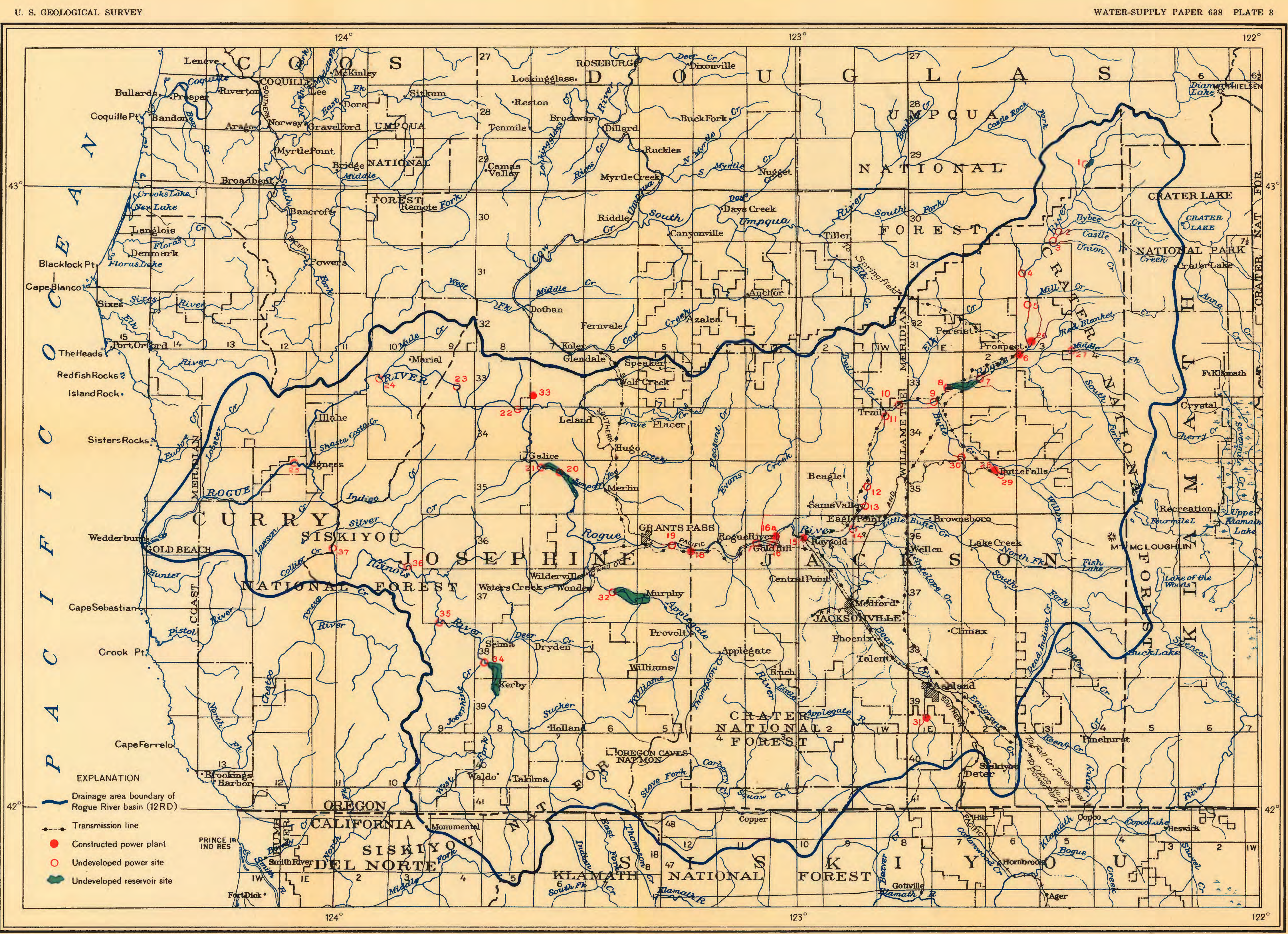

MAP OF SOUTHWESTERN OREGON AND NORTHWESTERN CALIFORNIA SHOWING DEVELOPED AND PROPOSED POWER SITES IN ROGUE RIVER BASIN

Scale 500000

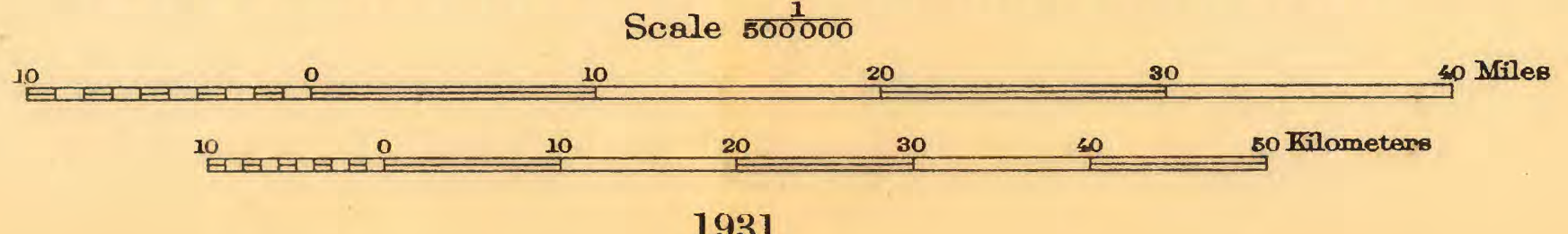




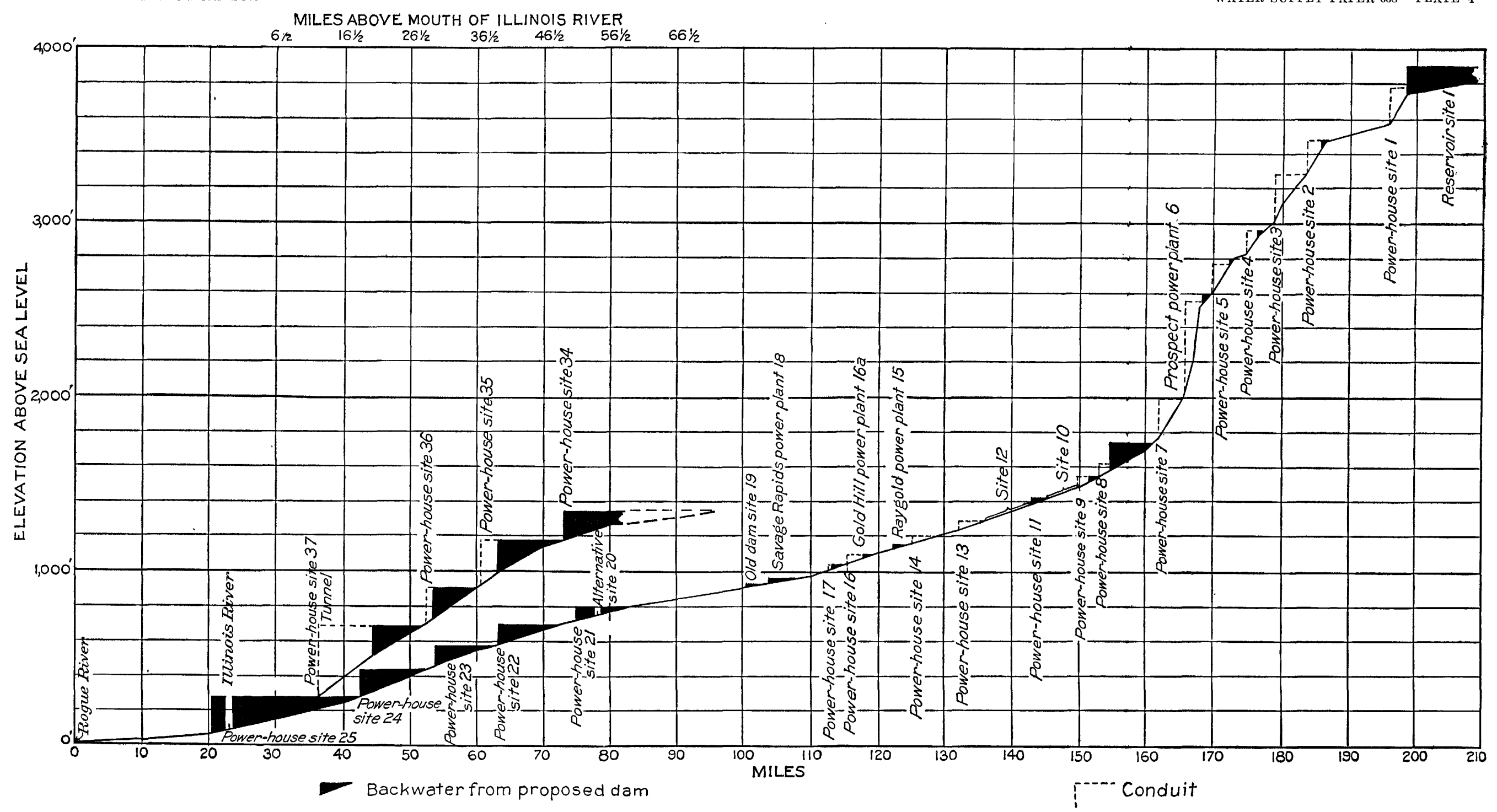

PROFILE OF THE ROGUE AND ILLINOIS RIVERS SHOWING LOCATION OF DAM SITES 


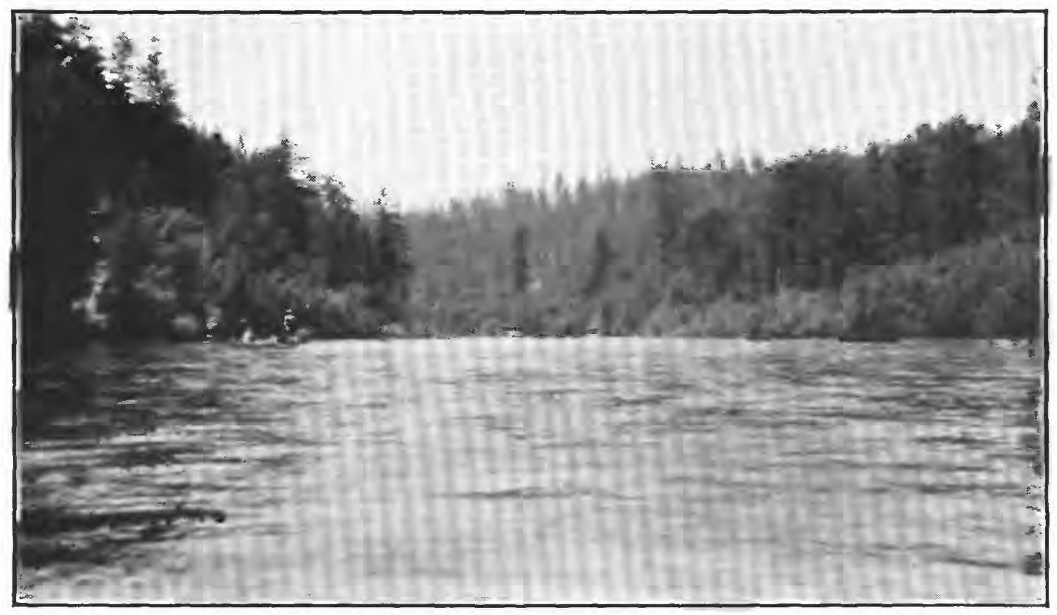

A. ROGUE RIVER ENTERING THE CANYON SECTION 12 MILES BELOW GRANTS PASS

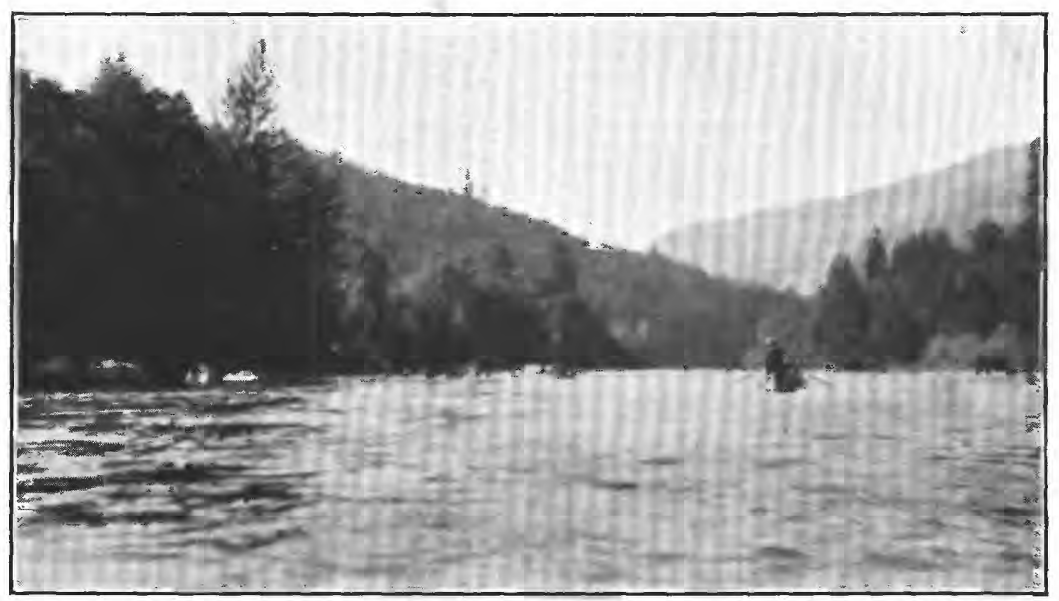

B. ROGUE RIVER 24 MILES BELOW GRANTS PASS 


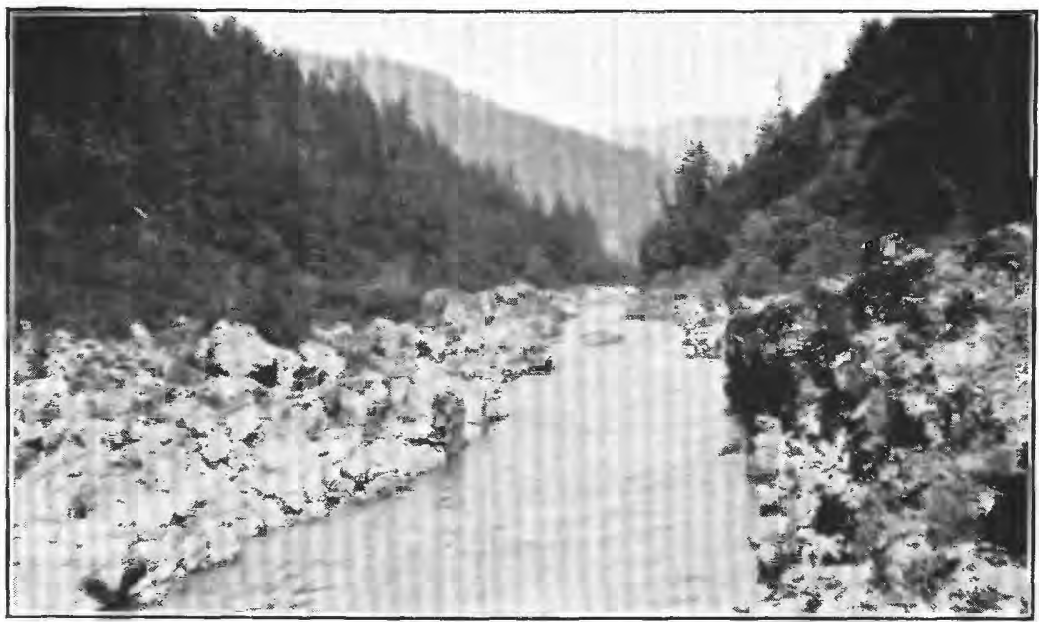

A. ROGUE RIVER LOOKING UPSTREAM FROM HOWARD CREEK

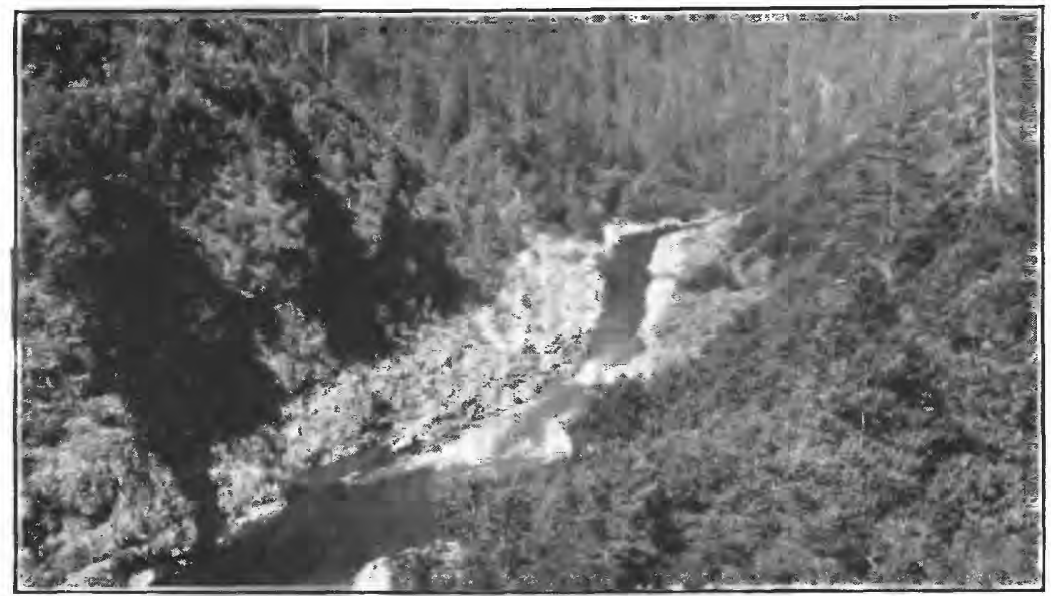

B. ROGUE River halF A MILE ABOVE BUNKER CREEK 


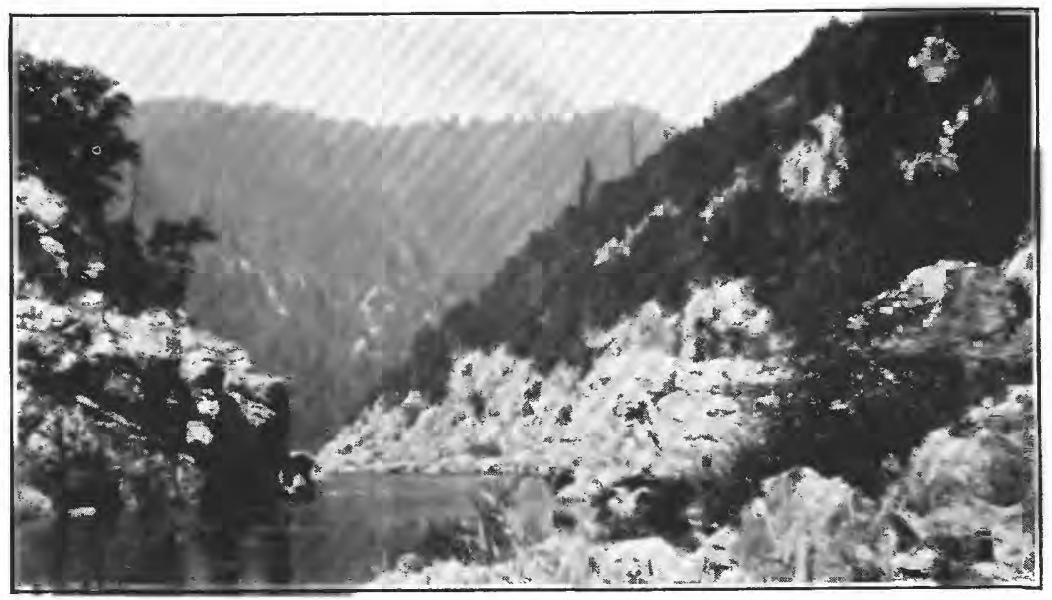

A. ROGUE RIVER IN SEC. 13 , T. 34 S., R. 8 W., HALF A MILE BELOW ALMEDA

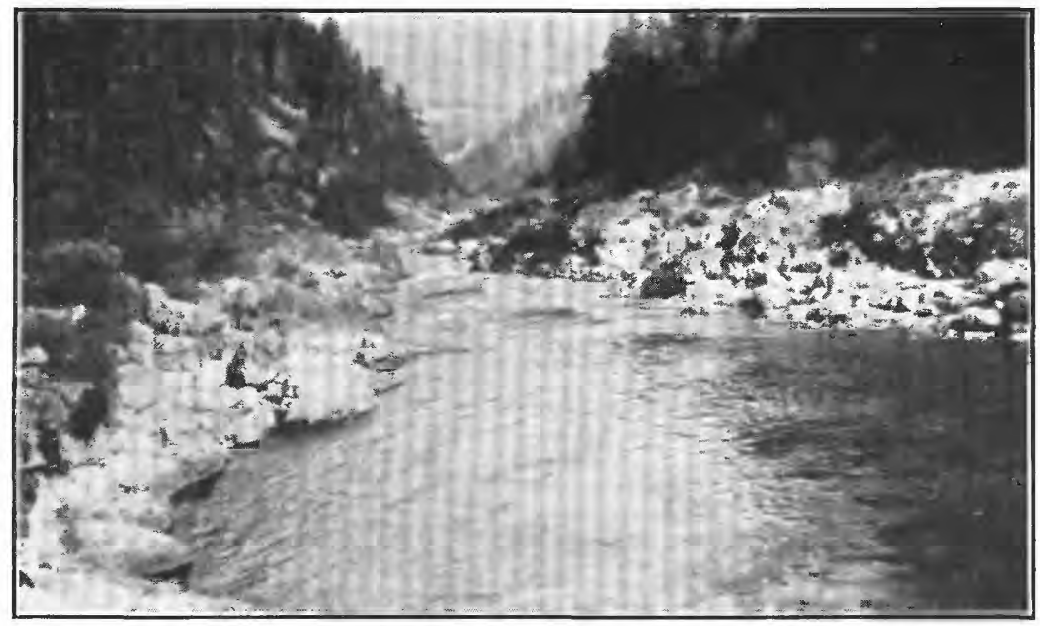

B. ROGUE RIVER HALF A MILE ABOVE CURRY-JOSEPHINE COUNTY LINE 


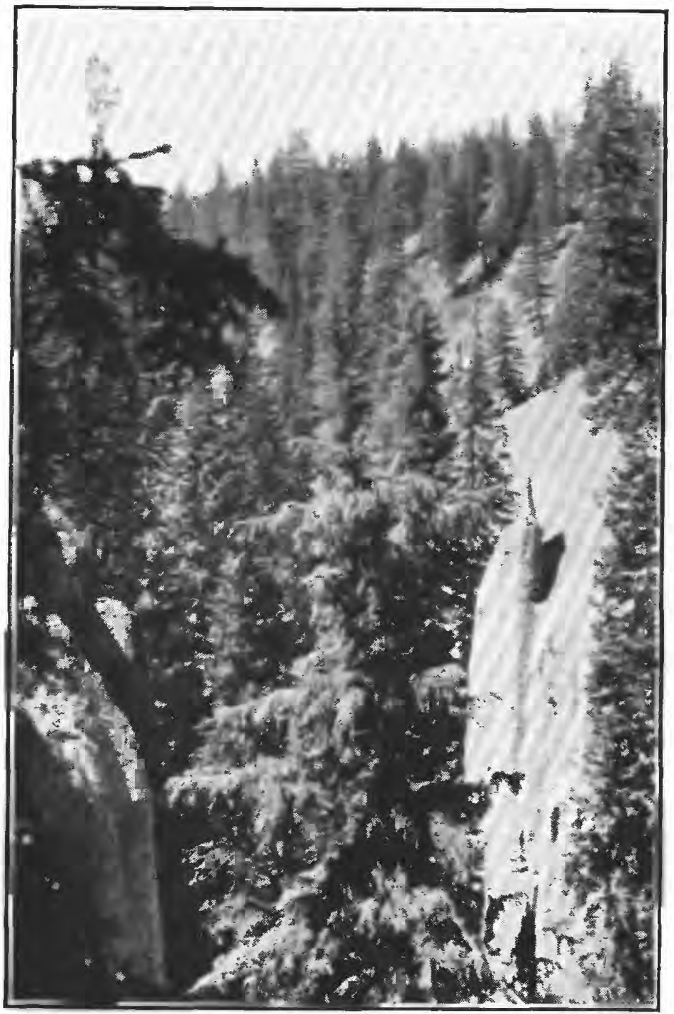

A. CANYON IN VOLCANIC ASH NEAR HEADWATERS OF ROGUE RIVER

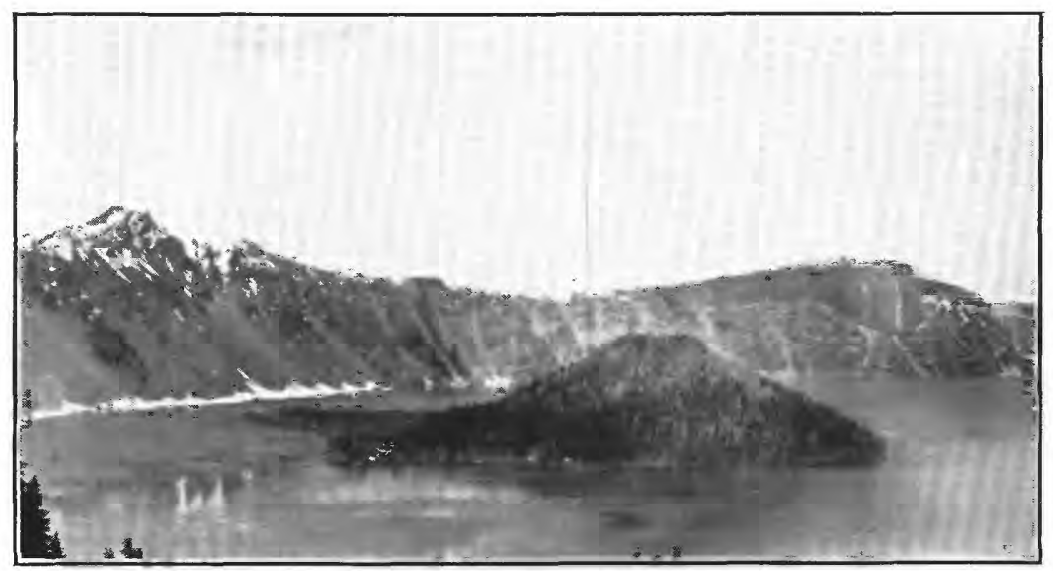

B. CRATER LAKE 

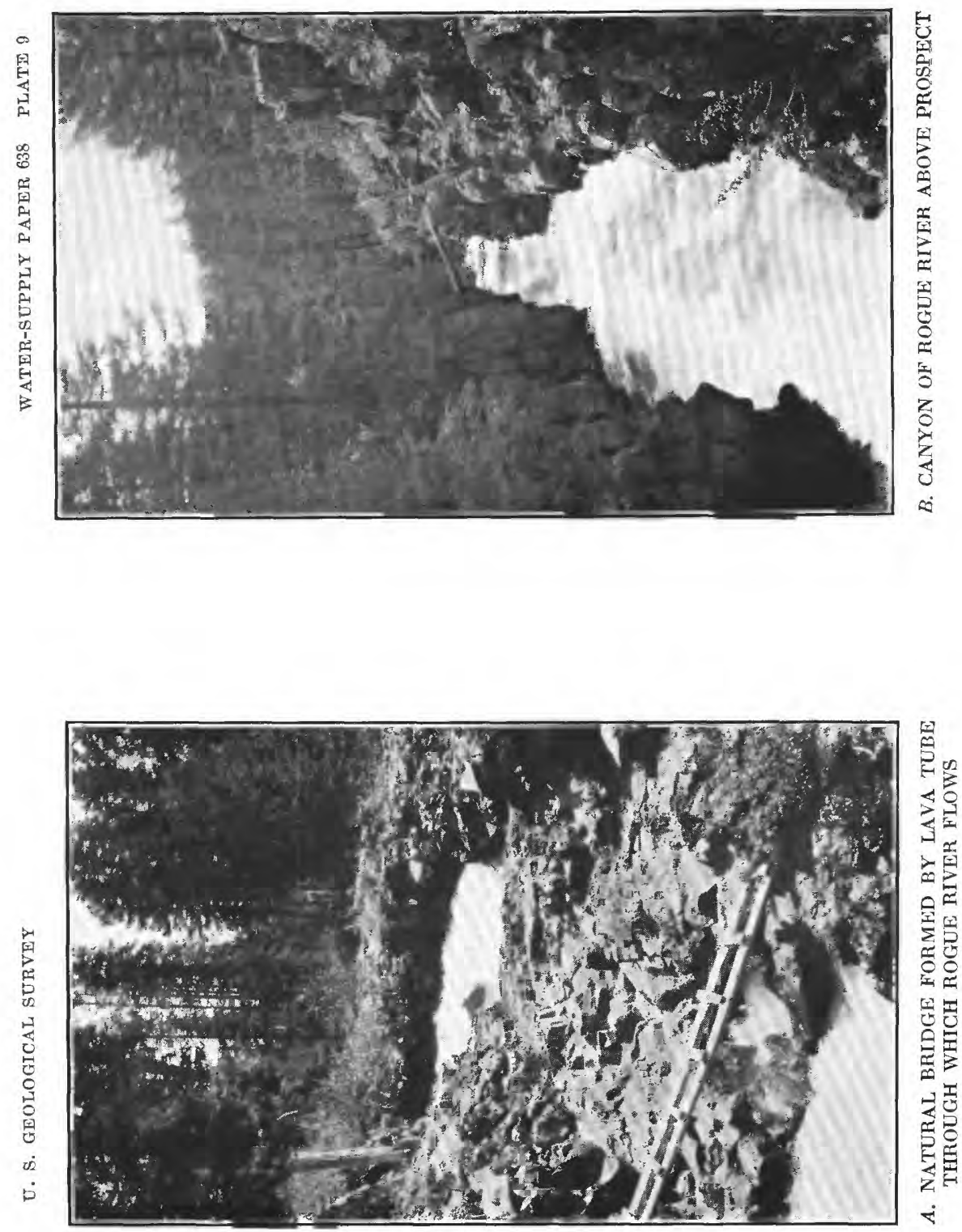


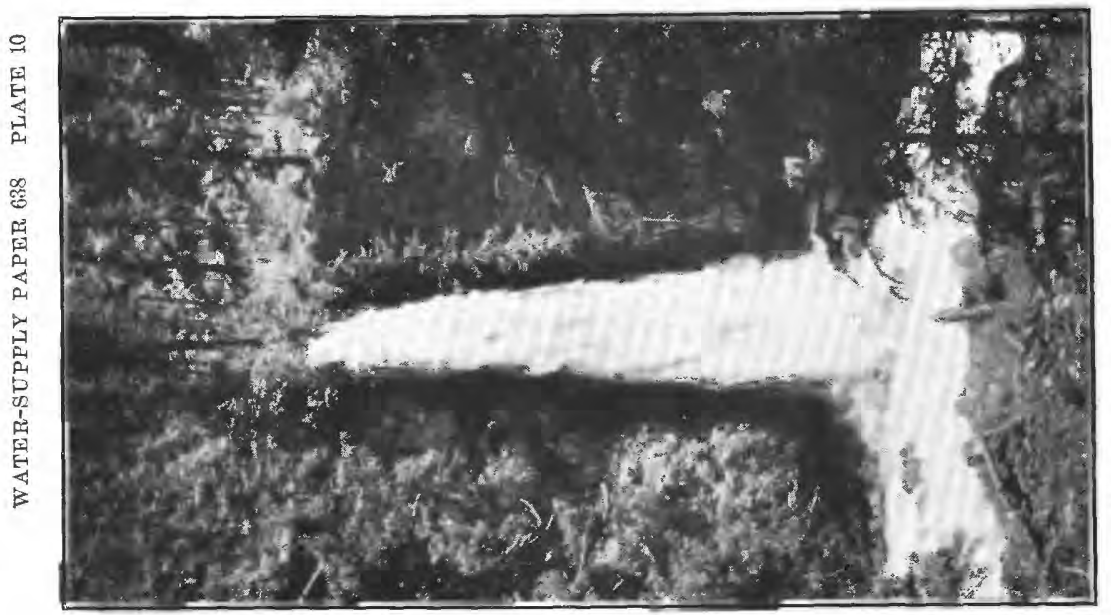

缹

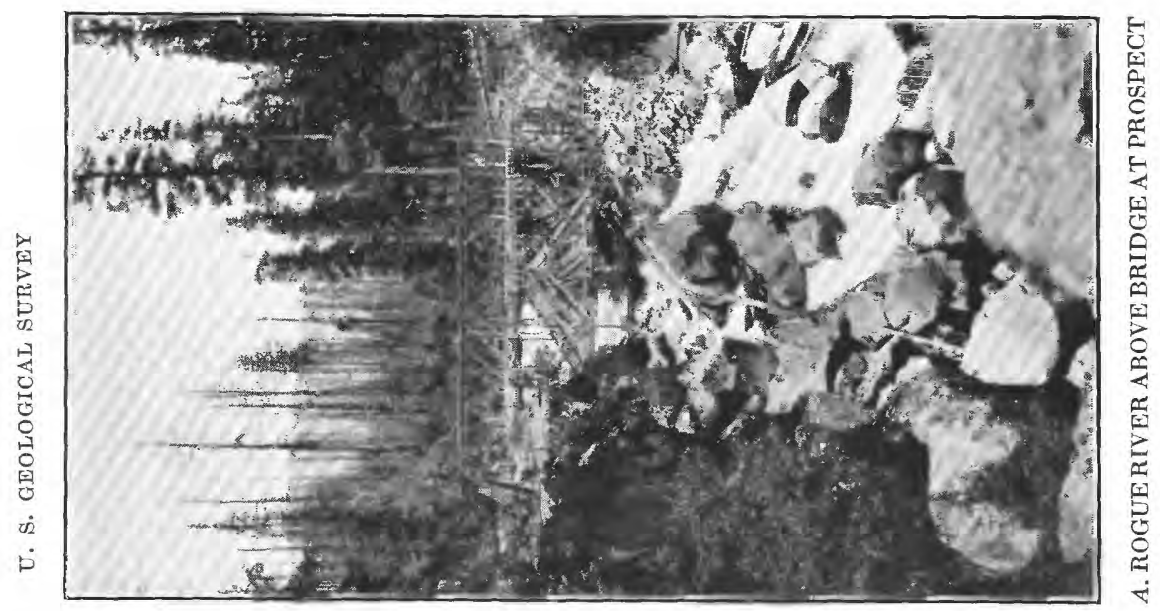


The table also shows that at only the highest points in the basin does the mean monthly temperature fall below the freezing point. In spite of the low winter temperatures at Crater Lake the lake itself never freezes over, but this is probably due to its great depth, as Diamond Lake and Klamath Lake freeze over during the winter, although both are at a much lower altitude.

The following precipitation table, based on Weather Bureau records, shows the monthly and annual rainfall at various points from west to east and also the way in which the rainfall is distributed. It may be noted that although the amount of precipitation at the various stations for the same month varies greatly, yet the trend at all the stations is the same, as there is a constant decrease from January to August and a constant increase from August to November, and December is usually somewhat lower than November.

TABLE 4.-Mean monthly precipitation, in inches, in the Rogue River Basin, Oreg.

\begin{tabular}{|c|c|c|c|c|c|c|c|c|c|}
\hline & $\begin{array}{l}\text { Gold } \\
\text { Beach }\end{array}$ & Agness & Galice & $\begin{array}{c}\text { Grants } \\
\text { Pass }\end{array}$ & $\begin{array}{l}\text { Med- } \\
\text { ford }\end{array}$ & $\begin{array}{c}\text { Jack- } \\
\text { sonville }\end{array}$ & $\begin{array}{l}\text { Ash- } \\
\text { land }\end{array}$ & $\begin{array}{l}\text { Butte } \\
\text { Falls }\end{array}$ & $\begin{array}{l}\text { Pros- } \\
\text { pect }\end{array}$ \\
\hline $\begin{array}{l}\text { January } \\
\text { February } \\
\text { March } \\
\text { April } \\
\text { May } \\
\text { June } \\
\text { July } \\
\text { Auguist } \\
\text { September } \\
\text { October } \\
\text { November } \\
\text { December }\end{array}$ & $\begin{array}{r}15.43 \\
14.50 \\
9.85 \\
5.00 \\
3.88 \\
1.87 \\
1.06 \\
.33 \\
1.38 \\
4.77 \\
14.24 \\
9.59\end{array}$ & $\begin{array}{r}10.27 \\
8.71 \\
7.79 \\
4.77 \\
1.84 \\
1.09 \\
.36 \\
.31 \\
2.61 \\
2.93 \\
9.40 \\
8.21\end{array}$ & $\begin{array}{r}12.10 \\
4.38 \\
3.35 \\
3.22 \\
1.85 \\
.67 \\
.49 \\
.08 \\
2.10 \\
3.17 \\
8.33 \\
7.01\end{array}$ & $\begin{array}{r}5.72 \\
4.59 \\
3.18 \\
1.71 \\
1.53 \\
.85 \\
.17 \\
.24 \\
.94 \\
1.91 \\
4.51 \\
4.98\end{array}$ & $\begin{array}{r}2.41 \\
1.99 \\
1.27 \\
1.48 \\
1.20 \\
.75 \\
.46 \\
.20 \\
.66 \\
1.02 \\
2.72 \\
2.21\end{array}$ & $\begin{array}{l}4.64 \\
3.64 \\
2.41 \\
1.48 \\
1.74 \\
1.00 \\
.38 \\
.36 \\
.88 \\
1.60 \\
3.87 \\
4.19\end{array}$ & $\begin{array}{r}2.97 \\
2.34 \\
1.96 \\
1.54 \\
1.66 \\
1.05 \\
.50 \\
.32 \\
.88 \\
1.37 \\
2.60 \\
3.08\end{array}$ & $\begin{array}{l}4.85 \\
3.54 \\
2.41 \\
2.87 \\
2.59 \\
1.60 \\
.84 \\
.34 \\
1.75 \\
2.13 \\
6.01 \\
3.69\end{array}$ & $\begin{array}{r}6.74 \\
4.96 \\
3.38 \\
2.97 \\
2.50 \\
1.31 \\
.74 \\
.34 \\
1.94 \\
3.15 \\
7.15 \\
4.42\end{array}$ \\
\hline Yearly mean & 81.90 & 58.29 & 46. 75 & 30.33 & 16.37 & 26.19 & 20.27 & 32. 62 & 39.60 \\
\hline
\end{tabular}

The snowfall ranges from only a trace at Gold Beach to a recorded depth of 354.8 inches at Crater Lake. It seems, however, that the amount recorded for Crater Lake must be largely drift snow, for on Wizard Island, which is somewhat sheltered from the wind, the snow line is clearly marked at about 12 feet, or 144 inches. $^{2}$

The annual precipitation along the course of the Rogue River itself averages 55 inches; ranging from somewhat over 75 inches near the coast to a minimum of 16 inches near Medford and then increasing again to about 75 inches near the headwaters. The two major tributaries of the Rogue River-the Mlinois and Applegate Rivershave an average precipitation of 68 and 38 inches, respectively. The range along the Illinois River is from 100 inches on the west side of the basin to about 50 inches on the east side; that along the Applegate River is from 55 inches on the west to 27 inches on the east.

2 Diller, J. S. and Patton, H. B., The geology and petrography of Crater Lake National Park; U. 8, Geol. Survey Prot. Paper 3, p. 60, 1902. 


\section{FACTORS AFFECTING HYDRAUHC STRUCTURES}

Ice will not materially interfere with the development of power on the Rogue River except possibly in the part of the basin above Prospect, and even there its effect is questionable. Though the temperature in the upper part of the basin in November, December, January, and February (see Table 3) is favorable for ice formation the discharge record at Prospect shows that the run-off increases steadily during these months. The records of the gaging station at Prospect indicate that there is no trouble due to ice. A possible explanation of the small amount of ice is that during the winter practically all of the discharge from the upper part of the basin comes from ground storage and springs and the temperature of the water from these sources is ordinarily considerably above freezing.

At all proposed developments provision must be made to carry the maximum flood flow without damage to the hydraulic structures. The floods in the upper part of the basin are not severe; and as the suggested plan of power development in this section includes only small diversion dams and canals, the excess flow can readily be carried by the main river channel. In the middle part of the basin low dams must be used in order that the damage due to flooding farm lands may be minimized. The banks here are low and are not very resistant to erosion. In order, therefore, that floods may be passed without allowing too much rise in the pond level, dams composed largely of gates must be used.

In the lower or canyon section of the river and on the Illinois River the floods may be severe, and either spillway tunnels or an overflow dam section must be used to pass the flood waters. Fortunately, most of the dams in these sections form large ponds in which the flow not capable of being passed by the wasteway will be stored, thereby ironing out the maximum flood peak.

The Rogue River is noted for its clear cold water, and no difficulty will be experienced with silt; all other débris is so small in amount that it can readily be disposed of without damage to plant or equipment.

A few of the proposed developments will necessitate the relocation of certain parts of highways, but an effort has been made throughout to provide for the maximum power available with minimum damage to present or proposed improvements. This can readily be accomplished, as the population of the district is very sparse and is, in general, concentrated in the agricultural portion of the basin, where the land is highly developed and where the slope of the river is so low as to preclude development for a long time. In the upper part of the basin the river grade is steep, and small dams with canals and pipe lines are suggested for the generation of power; such development will do little if any damage, considering the character of the 
country. In the lower part of the basin the river flows in a canyon that is occupied by few people and contains a very small proportion of agricultural land; in this section relatively high dams with adjacent power houses are suggested as a desirable method of development.

Between the town of Galice and the source of the Rogue River the stream is paralleled by a highway that could readily be improved sufficiently to enable construction machinery and materials to be transported. In the lower canyon sections of the Rogue and Illinois Rivers, however, no means of transportation other than pack animals exists, and trails could not be improved sufficiently to withstand heavy trucking except at considerable expense.

By constructing first the dam at Copper Canyon (site 12RD 25), the backwater would enable water transportation to be used on both the Rogue and Illinois Rivers practically to the next higher site; and by continuing this method through the canyon sections transportation difficulties would be largely overcome.

A small motor boat runs from the mouth of the Rogue River (see pl. 11, A) to the junction of the Illinois River at Agness, but if a highway were built the boat would be discontinued, so it is considered improbable that there will be any navigation above Copper Canyon except the driving of logs. Provision for passing logs should be made at all dams constructed on the river, and any permits or licenses should contain a provision permitting the United States to construct locks or other works for navigation at any of the dams if this is ever found desirable.

A suitable method of allowing fish to pass up the river must be worked out before any power dams can be built on the lower section of the Rogue River. At present power development on the lower river is prevented entirely by an act of the legislature in the interests of migratory fish. Projects begun prior to the passage of the act, which was approved March 4, 1929, are probably not affected by it.

\section{WATER SUPPLY}

\section{SEAsONAL VARIATION IN STREAM FLOW}

The annual precipitation ranges from 16 to 75 inches at different points in the basin but has the same general seasonal distribution at the different stations. The precipitation in the higher parts of the basin during the winter is largely in the form of snow, which contributes markedly to the stream flow during March, April, May, and June. The upper part of the basin is heavily timbered, and the soil is composed of a very porous volcanic material that absorbs during the rainy season an immense quantity of water, which is gradually released during the remainder of the year. The sustained flow in the headwater streams during the dry season has been attributed by 'many persons to the presence of Crater Lake, (See pl. 8, B.) The 
following very rough analysis, based largely on data given by Diller and Patton, ${ }^{3}$ shows that this belief is hardly warranted, as less than 10 per cent of the flow can be so accounted for. The yearly fluctuation in the stage of Crater Lake is about 4 feet. During the rainy season the water level rises, and during the dry season it falls. Records of the lake level taken during the month of September at varying intervals from 1892 to 1901 disclose the fact that the low stage did not change appreciably during that time. As the level of the lake is practically constant from year to year, the only water that can be contributed to the headwater streams is that due to the excess of precipitation over all other losses. The precipitation is possibly as high as 80 inches a year, and evaporation, which is the source of by far the greatest loss, is about 46 inches a year. The difference, or 34 inches, is available to feed the small streams. The total water and tributary drainage area is about 27.5 square miles, of which all but 7.9 miles is in the lake; the error introduced by treating the whole area as a unit will be small. The total area multiplied by the net amount of water received, with the necessary factors applied to reduce the result to acre-feet, gives about 50,000 acre-feet. This volume of water uniformly distributed throughout the year is the equivalent of a constant addition to the streams heading around Crater Lake of about 70 second-feet, whereas the combined flow of these streams is over 1,000 second-feet. The base data are possibly somewhat in error, but it is hardly conceivable that the error is sufficiently great to account for this difference.

Records of the discharge of the Rogue River at Raygold * beginning August 30, 1905, are given in Tables 5 and 6; records for sta tions above and below Prospect covering shorter periods are given in Tables 7 and 8. A list of all gaging stations that have been maintained in the Rogue River Basin, with the period of record, is given as Table 13. Unless otherwise indicated all stream-flow records cover the 12-month period ending September 30.

July, August, September, and October constitute the period of low run-off; the discharge for January, February, March, April, and May is uniformly high; and that for November, December, and June approximates the average annual flow. During March, April, May, June, July, and August the rainfall constantly decreases, but in spite of this the melting snow keeps the run-off high for the first four months of the period. This effect is particularly evident in the records both above and below Prospect, but at Raygold the deficiency in rainfall and the depletion of the ground-water storage are more than can be

- Diller, J. S., and Patton, H. B., op. cit., pp. 53-61.

- This station is in sec. 18, T. 36 S., R. 2 W., at Raygold rallroad station, half a mille below the mouth of Bear Creek. Records at this station for the years 1906-1921 read "Rogue River near Tolo, Oreg." The post office at Tolo having been discontinued, the designation of the gaging station was changed beginning 1922 to "Rogue River at Raygold, near Çentral Point, Oreg." 
offset by the run-off from melting snow, and the discharge falls rapidly. The great increase of the discharge below Prospect over that above Prospect during this period is worthy of note. It is due in small part to the slightly greater drainage area at the lower station but chiefly to the fact that between the two stations the Rogue River cuts down through about 500 feet of water-bearing strata (see pl. $9, B$ ), in which are many springs and seepages. The low-water period extends from July to October at all stations.

\section{ANNUAL YIRLD AND MINIMUM FLOW}

The records in the Rogue River Basin are not sufficiently long to show the existence of cycles of heavy and light run-off nor any general trend. However, a comparison of the shorter records with those at Raygold gives some idea whether the flow recorded at each station was higher or lower than normal. The index of wetness is found by dividing the total annual precipitation for any one year by the mean annual precipitation for a long period of years. According to the records of discharge above Prospect the index of wetness for 1908 to 1912 at that station is only slightly above normal, and that for 1924

- to 1927 is below normal. Below Prospect the index of wetness for the period 1916 to 1926 is about 14 per cent below normal. The record of discharge at Raygold has been compared with the longer records on the Columbia River at The Dalles and the Willamette River at Albany and with the rainfall records. The longest discharge record is that of the Columbia River at The Dalles, which began in 1879. This record shows that the low years were 1889, 1891, 1905, 1915, 1924, and 1926. The lowest year was probably 1926 . The precipitation record for western Oregon also shows a continued low period from 1915 to 1926 and an extremely dry period from 1922 to 1926 . For 1889 there are few data except the record of the flow of the Columbia River at The Dalles on which to base an estimate of the dryness in the Rogue River Basin; but a note in a Weather Bureau report for 1889 states that the year was very dry in eastern Oregon and in the lower Willamette Valley, so it is inferred that in southwestern Oregon there was more precipitation, and the records of rainfall bear out this inference. In 1891 the precipitation in western Oregon was 71 per cent of the mean, and in 1926 it was 70 per cent of the mean. These rather meager facts seem to indicate that the flow of the Rogue River was lower in 1926 than in either 1889 or 1891 . In 1905 the precipitation was 91 per cent of the mean. The run-off of the Willamette River at Albany was nearly 2 inches greater than in 1926. The minimum flow of the Rogue River at Raygold in September, 1905, was 1,240 second-feet, compared with 860 second-feet in 1926. So undoubtedly the discharge of Rogue River was greater in 1905 than in 1926. Beginning 
with 1906 stream-flow records are available on the Rogue River at Raygold.

From the records on the Columbia River beginning 1879 and the precipitation records for western Oregon beginning 1891 it can be assumed that a year of low flow will occur once for each 8 or 10 years of record and a year of very low flow will occur once in a much longer period. The low years may not occur 10 years apart, however, for records of stream flow seem to indicate cycles of flow, several dry years occurring close together. No method is known for predicting the length, time of occurrence, or cause of such cycles. Plotting the index of wetness for western Oregon for the 36 years ending 1926 against the number of times each figure was equaled or exceeded indicates that a year as dry as 1926 will probably occur only once in scores of years.

The records on the Rogue River include the low period from 1915 to 1926 , and the estimates of power available are based on this record. The power estimates are therefore conservative and probably are somewhat low. The Q90 flow (see Table 6) is shown to be remarkably consistent, ranging from 1,030 to 1,543 second-feet, except in 1924 , when it fell to 867 second-feet, and in 1926, when it was only 819 second-feet. The Q50 flow ranged from 1,579 to 3,722 second-feet, except in 1924, when it fell to 1,400 second-feet, and in 1926 , when it was 1,300 second-feet. The maximum recorded discharge of the Rogue River at Raygold was 60,000 second-feet, but the mean flow for the day on which that stage occurred was 48,300 second-feet. The minimum recorded daily discharge at Raygold was 770 second-feet in 1926. Prior to 1924, when it was 813 second-feet, the minimum recorded mean daily discharge was 937 second-feet.

The run-off at Raygold during a normal year is about $2,200,000$ acre-feet. For the years 1906 to 1927 the flow 50 per cent of the time was 2,150 second-feet and the flow 90 per cent of the time was 1,180 second-feet. The maximum annual flow of record on the Rogue River at Raygold occurred during the year 1906-7, when 3,030,000 acre-feet passed the gaging station, and during four other years the flow has been in excess of 2,500,000 acre-feet. The flow in 1925-26, when only $1,100,000$ acre-feet passed the station, is the minimum of record, although it was only slightly less than the flow of $1,220,000$ acre-feet during the year 1923-24. The results of miscellaneous measurements made in the Rogue River Basin in July and September, 1923, are given in Table 9. Because of an exceptionally dry summer the September measurement given is probably somewhat below the normal low flow. 
TABLE 5.-Summary of monthly mean discharge, in second-feet, of Rogue River at Raygold, Oreg., 1906-1927

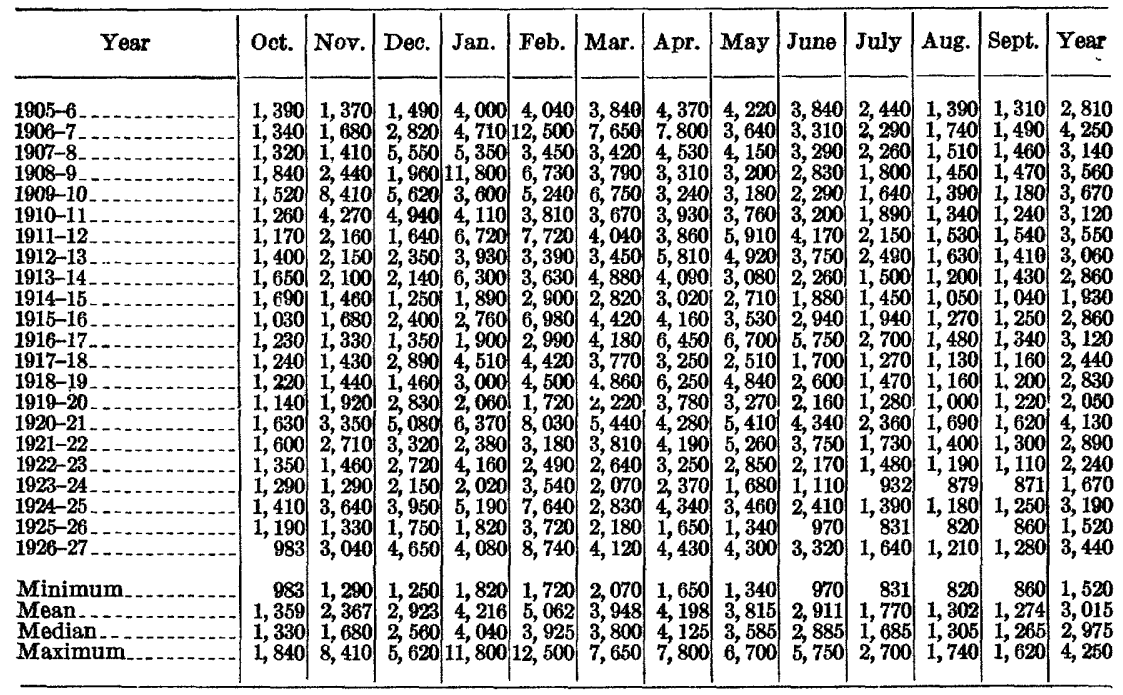

TABLE 6.-General summary of stream-flow data of Rogue River at Raygold, Oreg., 1906-1927

\begin{tabular}{|c|c|c|c|c|c|c|c|}
\hline \multirow{2}{*}{ Year } & \multicolumn{5}{|c|}{ Diseharge in second-feet } & \multirow{2}{*}{$\begin{array}{l}\text { Index of } \\
\text { run-off } a\end{array}$} & \multirow{2}{*}{$\begin{array}{l}\text { Index of } \\
\text { wetness b }\end{array}$} \\
\hline & Q90 & Q50 & $\begin{array}{l}\text { Mini- } \\
\text { mum }\end{array}$ & $\begin{array}{l}\text { Maxi- } \\
\text { mumi }\end{array}$ & Mean & & \\
\hline $\begin{array}{l}1905-6 \\
1906-7 \\
1907-8 \\
1908-9 \\
1909-10 \\
1910-11 \\
1911-12 \\
1913-13 \\
1914-15 \\
1915-16 \\
1916-17 \\
1917-18 \\
1918-19 \\
1919-20 \\
1920-21 \\
1921-22 \\
1922-23 \\
1923-24 \\
1924-25 \\
1925-26 \\
1926-27\end{array}$ & $\begin{array}{l}1,312 \\
1,349 \\
1,345 \\
1,469 \\
1,346 \\
1,264 \\
1,249 \\
1,417 \\
1,275 \\
1,060 \\
1,157 \\
1,265 \\
1,147 \\
1,147 \\
1,041 \\
1,543 \\
1,376 \\
1,186 \\
1,1567 \\
1,819 \\
1,030\end{array}$ & $\begin{array}{l}2,408 \\
2,789 \\
2,896 \\
2,412 \\
2,652 \\
2,655 \\
2,625 \\
-2,845 \\
2,167 \\
1,579 \\
2,245 \\
1,950 \\
1,912 \\
1,663 \\
1,716 \\
3,722 \\
2,329 \\
1,933 \\
1,400 \\
2,540 \\
1,300 \\
3,030\end{array}$ & $\begin{array}{r}1,230 \\
1,270 \\
1,190 \\
1,320 \\
1,180 \\
1,120 \\
1,120 \\
1,180 \\
1,180 \\
960 \\
962 \\
1,010 \\
1,060 \\
948 \\
937 \\
1,220 \\
1,200 \\
1,050 \\
813 \\
875 \\
770 \\
840\end{array}$ & $\begin{array}{r}27,800 \\
48,300 \\
29,400 \\
29,800 \\
48,300 \\
31,000 \\
35,000 \\
11,300 \\
21,200 \\
9,700 \\
15,800 \\
9,100 \\
16,700 \\
12,700 \\
7,480 \\
19,300 \\
15,400 \\
15,600 \\
9,300 \\
33,900 \\
6,020 \\
48,900\end{array}$ & $\begin{array}{l}2,810 \\
4,250 \\
3,140 \\
3,550 \\
3,670 \\
3,110 \\
3,530 \\
3,050 \\
2,850 \\
1,920 \\
2,840 \\
3,110 \\
2,430 \\
2,820 \\
2,050 \\
4,110 \\
2,880 \\
2,240 \\
1,670 \\
3,190 \\
1,550 \\
3,440\end{array}$ & $\begin{array}{r}0.97 \\
1.46 \\
1.08 \\
1.22 \\
1.26 \\
1.07 \\
1.21 \\
1.05 \\
.98 \\
.66 \\
.98 \\
1.07 \\
.84 \\
.97 \\
.71 \\
1.40 \\
.99 \\
.77 \\
.57 \\
1.10 \\
.52 \\
1.18\end{array}$ & $\begin{array}{r}1.00 \\
1.21 \\
1.02 \\
1.05 \\
1.06 \\
1.00 \\
1.05 \\
1.00 \\
1.05 \\
.76 \\
1.16 \\
.78 \\
.82 \\
.93 \\
.79 \\
1.05 \\
.86 \\
.87 \\
.61 \\
.94 \\
.70 \\
1.19\end{array}$ \\
\hline $\begin{array}{l}\text { Minimum } \\
\text { Mean } \\
\text { Median } \\
\text { Maximum.... }\end{array}$ & $\begin{array}{r}819 \\
1,219 \\
1,257 \\
1,543\end{array}$ & $\begin{array}{l}1,300 \\
2,308 \\
2,368 \\
3,722\end{array}$ & $\begin{array}{r}770 \\
1,065 \\
1,090 \\
1,320\end{array}$ & $\begin{array}{r}6,020 \\
22,820 \\
18,000 \\
48,900\end{array}$ & $\begin{array}{l}1,520 \\
2,910 \\
2,950 \\
4,250\end{array}$ & 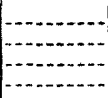 & 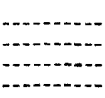 \\
\hline
\end{tabular}

a Yearly mean divided by the mean for the period.

- Yearly precipitation for western Oregon divided by the Iong-time' average. 
TABLE 7.-Summary of combined monthly mean discharge in second-feet, of Rogue River and the California-Oregon Power Co.'s flume below Prospect, Oreg., 1916-1926

\begin{tabular}{|c|c|c|c|c|c|c|c|c|c|c|c|c|c|}
\hline Year & Oct. & Nov. & Dec. & Jan. & Feb. & Mar. & Apr. & May & June & July & Aug. & Sept. & Year \\
\hline $\begin{array}{l}1915-16 \\
1910-17- \\
1917-18- \\
1918-19- \\
1919-20=- \\
1920-21- \\
1921-22- \\
1922-23=- \\
1923-24=- \\
1924-25= \\
1925-26=\end{array}$ & $\begin{array}{l}571 \\
670 \\
677 \\
599 \\
605 \\
774 \\
834 \\
757 \\
614 \\
390 \\
\mathbf{4 6 8}\end{array}$ & $\begin{array}{r}763 \\
704 \\
740 \\
615 \\
893 \\
1,210 \\
1,220 \\
763 \\
654 \\
873 \\
494\end{array}$ & $\begin{array}{r}1,000 \\
686 \\
1,220 \\
579 \\
936 \\
1,160 \\
1,320 \\
832 \\
878 \\
921 \\
628\end{array}$ & $\begin{array}{r}705 \\
669 \\
1,670 \\
902 \\
956 \\
1,510 \\
1,914 \\
1,140 \\
1,350 \\
1,300 \\
574\end{array}$ & $\begin{array}{r}1,710 \\
786 \\
1,340 \\
941 \\
842 \\
1,560 \\
882 \\
1,797 \\
1,240 \\
1,170 \\
1,170\end{array}$ & $\mid \begin{array}{r}1,750 \\
796 \\
1,340 \\
921 \\
806 \\
1,660 \\
1,073 \\
1,020 \\
1,071 \\
1,870 \\
879\end{array}$ & $\begin{array}{l}2,020 \\
1,700 \\
1,760 \\
1,900 \\
1,190 \\
1,720 \\
1,400 \\
1,420 \\
1,020 \\
1,470 \\
761\end{array}$ & \begin{tabular}{|l}
2,000 \\
2,600 \\
1,560 \\
1,940 \\
1,480 \\
1,950 \\
2,250 \\
1,590 \\
1,544 \\
1,550 \\
571
\end{tabular} & $\begin{array}{l}1,870 \\
2,880 \\
1,040 \\
1,280 \\
1,020 \\
1,810 \\
1,910 \\
1,190 \\
1,88 \\
1,030 \\
403\end{array}$ & $\begin{array}{r}1,280 \\
1,640 \\
702 \\
746 \\
686 \\
1,100 \\
973 \\
804 \\
519 \\
591 \\
338\end{array}$ & $\begin{array}{l}783 \\
841 \\
608 \\
637 \\
567 \\
868 \\
825 \\
644 \\
485 \\
504 \\
320\end{array}$ & $\begin{array}{l}719 \\
715 \\
599 \\
622 \\
606 \\
884 \\
773 \\
615 \\
479 \\
498 \\
305\end{array}$ & $\begin{array}{r}1,260 \\
1,230 \\
1,100 \\
972 \\
883 \\
1,340 \\
1,190 \\
964 \\
738 \\
1,000 \\
572\end{array}$ \\
\hline
\end{tabular}

TABLE 8.-Summary of monthly mean discharge, in second-feet, of Rogue River above Prospect, Oreg., 1908-1912 and 1924-1927

\begin{tabular}{|c|c|c|c|c|c|c|c|c|c|c|c|c|c|}
\hline Year & Oct. & Nov. & Dec. & Jan. & Feb. & Mar. & Apr. & May & June & July & Alag. & Sept. & Year \\
\hline $\begin{array}{l}1907-8 \\
1908-9- \\
1900-10 \\
1910-11\end{array}$ & $\begin{array}{l}576 \\
496 \\
529\end{array}$ & $\begin{array}{r}532 \\
-650 \\
966\end{array}$ & $\begin{array}{r}468 \\
1,320 \\
1,070\end{array}$ & $\begin{array}{r}901 \\
515\end{array}$ & $\begin{array}{l}590 \\
791 \\
982 \\
601\end{array}$ & $\begin{array}{r}801 \\
715 \\
1,390 \\
887\end{array}$ & $\begin{array}{l}1,180 \\
1,232 \\
1,090 \\
1,090\end{array}$ & $\begin{array}{l}1,130 \\
1,020 \\
1,160 \\
1,210\end{array}$ & $\begin{array}{r}1,060 \\
915 \\
768 \\
1,140\end{array}$ & $\begin{array}{l}572 \\
445 \\
510 \\
511\end{array}$ & $\begin{array}{l}417 \\
440 \\
464 \\
443\end{array}$ & $\begin{array}{l}443 \\
458 \\
502 \\
487\end{array}$ & 787 \\
\hline $\begin{array}{l}1923-24 \\
1924-25 \\
1925-26 \\
1926-27\end{array}$ & 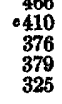 & $\begin{array}{r}641 \\
\quad 439 \\
843 \\
422 \\
784\end{array}$ & $\begin{array}{l}516 \\
666 \\
856 \\
558 \\
956\end{array}$ & $\begin{array}{r}, 480 \\
1,033 \\
1,030 \\
503 \\
806\end{array}$ & $\begin{array}{r}936 \\
1,490 \\
1,050 \\
1,280\end{array}$ & $\begin{array}{l}572 \\
782 \\
767 \\
846\end{array}$ & $\begin{array}{r}710 \\
1,200 \\
1,049 \\
1,070\end{array}$ & $\begin{array}{r}591 \\
1,280 \\
1,597 \\
1,540\end{array}$ & $\begin{array}{r}389 \\
801 \\
356 \\
1,330\end{array}$ & $\begin{array}{l}321 \\
477 \\
302 \\
620\end{array}$ & $\begin{array}{l}297 \\
409 \\
294 \\
460\end{array}$ & $\begin{array}{l}2905 \\
408 \\
283 \\
462\end{array}$ & $\begin{array}{l}5811 \\
823 \\
501 \\
869\end{array}$ \\
\hline
\end{tabular}

- November 1-19.

b December 10-31.

- Estimatod.

TABLE 9.-Miscellaneous discharge measurements in the Rogue River drainage basin, Oreg., during the year ending September 30,1923

\begin{tabular}{|c|c|c|c|c|}
\hline Date & Stream & Tributary to- & Location & $\begin{array}{l}\text { Discharge } \\
\text { (second- } \\
\text { feet) }\end{array}$ \\
\hline & Boundary Springs. & Rogue Ri & NE.1/4 sec. 4, T. 28 S., R. & \multirow{15}{*}{$\begin{array}{c}42.3 \\
27.5 \\
14.1 \\
5.22 \\
1.56 \\
4.23 \\
1.72 \\
45.7 \\
35.0 \\
49.4 \\
43.4 \\
65.1 \\
45.6 \\
39.2 \\
25.2 \\
30.5 \\
14.1 \\
62.3 \\
49.3 \\
29.9 \\
23.3 \\
4.93 \\
163\end{array}$} \\
\hline $\begin{array}{l}\text { Sept. } 5 \\
\text { July } 18 .\end{array}$ & Minnehaha Creek. & ...do. do. & SW. 1/4os. 11, T. 29 S., R. 4 E. & \\
\hline Sept. 5 & Homaker cree & do & $\mathrm{N}_{\mathrm{N}} \mathrm{dec} 15 \mathrm{~T} 2 \mathrm{~S} \mathrm{R}$ & \\
\hline 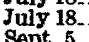 & Hurryon Creel & & SE. $1 / 4$ sec. 15, T. 29 S., R. 41 & \\
\hline July 18 & National Creek & -do. & NE. $1 / 4$ sec. 32, T. $29 \mathrm{~B} .$, R. $4 \mathrm{E}$ & \\
\hline July 16 & Copeland Creek. & 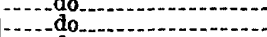 & NE. $1 / 4$ sec. 8, T. 30 S., R. 4 E. & \\
\hline $\begin{array}{l}\text { Sept. } 10 \\
\text { July } 16\end{array}$ & Crater Creek. & $\begin{array}{ll}- \text { do } \\
\therefore \text { do. }\end{array}$ & NE. $1 / 4$ sec. 5, T. 30 S., R. $4 \mathrm{E}$ & \\
\hline $\mathrm{Juj}$ & Bybee Creek. & $\begin{array}{l}\text { do } \\
\text { do }\end{array}$ & $\mathrm{NE} .1 / 4 \mathrm{sec} .26$, T. $30 \mathrm{~s} .$. R.3 E. & \\
\hline & & What & $-a 0_{0}$ & \\
\hline $\begin{array}{l}\text { Juig } 16 \\
\text { Sent } 10\end{array}$ & Castle Creek........ & ....-do- & SE. $1 / 4$ sec. 26 , T. 30 S., R. 3 E. & \\
\hline July 11 & Union Creek & -.-do & 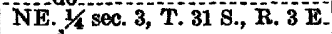 & \\
\hline & Miin Co & $\begin{array}{l}\text {-.do } \\
- \text { do }\end{array}$ & Sec. 33, T. 31 s., R. $3 \mathrm{E}$ & \\
\hline & & do & & \\
\hline 3 & \multirow{2}{*}{$\begin{array}{l}\text { Bar Cree } \\
\text { Middle Fork of Rogue } \\
\text { River. }\end{array}$} & - do & Sec $32, T, 32 \mathrm{~S}, \mathrm{R} .3 \mathrm{E}$ & \\
\hline & & & T. 33 \&., R. 3 E. & \\
\hline 19. & South Fork of Rogue & Midale Fork of Rogue & sE. $1 / 4 \mathrm{sec} 12, \mathrm{~T}, 33 \mathrm{~S}, 0$ & $\begin{array}{l}128.5 \\
184.8\end{array}$ \\
\hline $\begin{array}{l}\text { Sept. } 6 \text { - } \\
\text { Juiy } 17 .\end{array}$ & Red Blanket Creek & 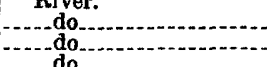 & Sec. 33, T. 32 S., R. 3 E. & $\begin{array}{l}75.3 \\
91.0\end{array}$ \\
\hline July 21 & Willow Creek. & Big Butte Creek. & NE. $1 / 4$ sec. 20 , T. 35 S., R.3 E. & 71.0 \\
\hline Ju & $\begin{array}{l}\text { Rancheria } \\
\text { Elk Creek. }\end{array}$ & Rogue Rjver. & $\mathrm{Sec}, 30, \mathrm{~T} .33 \mathrm{~S}, \mathrm{R}, \mathrm{IE}$ & $\begin{array}{l}17.8 \\
17.2\end{array}$ \\
\hline & Ilinois River. & ....do. & Kerby, or & \\
\hline & ....do_ & do. & (ndo & $\begin{array}{ll}65.2 \\
29.0\end{array}$ \\
\hline
\end{tabular}




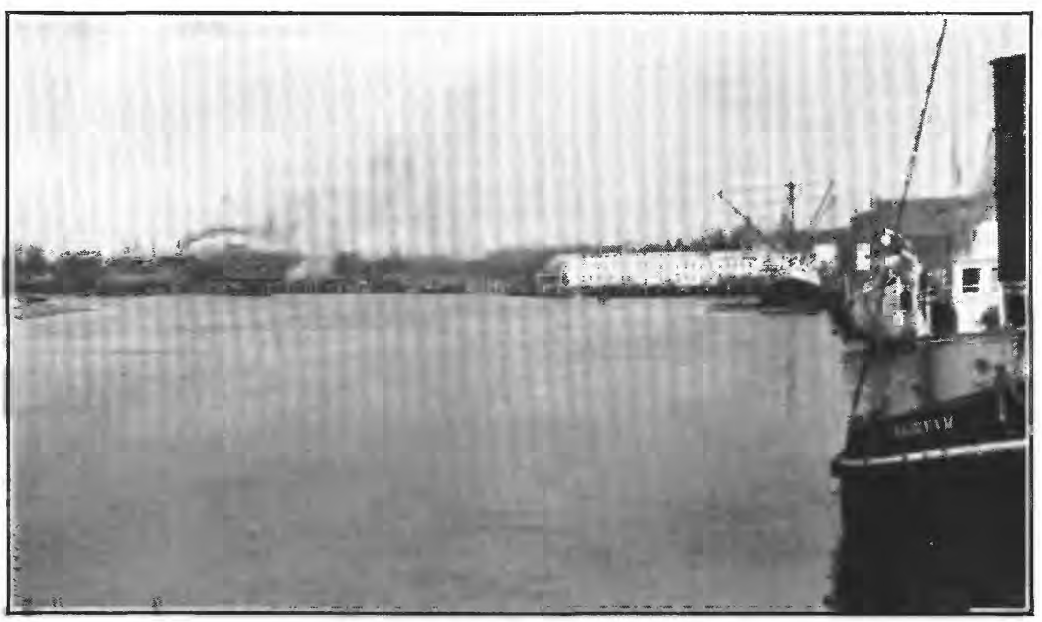

A. MOUTH OF ROGUE RIVER

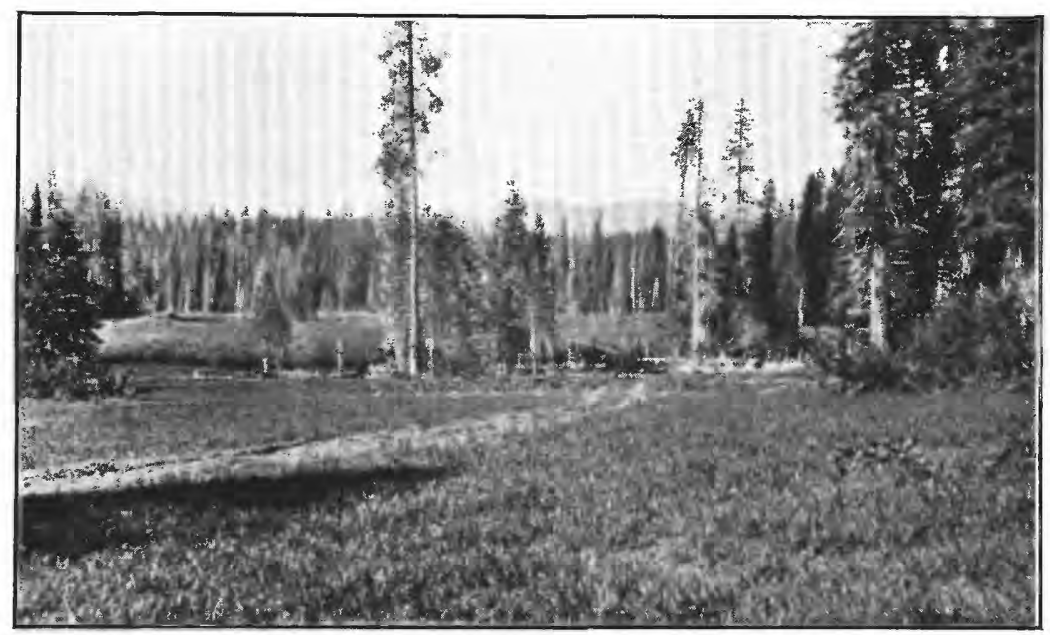

B. HAMAKER RESERVOIR SITE, ROGUE RIVER 

Along the Illinois River the soil of the mountain sides is shallow, and the volcanic ash that acts as a reservoir on the upper Rogue River is lacking; therefore the run-off follows closely on the rainfall, and the period of low precipitation in the summer is a period of very low flow. Precipitation records indicate a mean annual precipitation of 68 inches for the entire basin, and the mean for a 12-year period at Buckhorn Ranch, in the upper Illinois Basin, was 70 inches. The following discharge records were obtained during the investigation of the power possibilities of the Illinois River.

Mean monthly discharge of the Illinois River near Kerby, Oreg., 1983

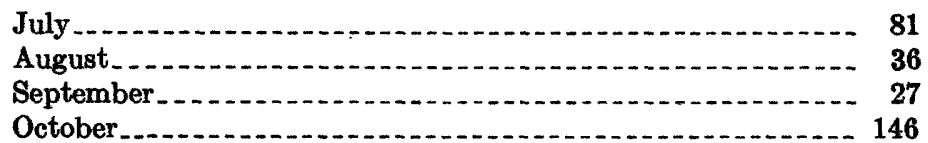

Discharge records for the Illinois River at Kerby for the years ending September 30, 1927 and 1928, have been obtained by the State engineer of Oregon and are published in Water-Supply Papers 654 and 674.

Two measurements of the Illinois River made in 1910 by W. $\mathbf{E}$. Herrings, former district engineer, United States Forest Service, were as follows: September 15, below Rancheria Creek, 43 second-feet; October 1, at mouth, 82 second-feet.

The estimates of stream flow and potential power on the Mlinois River are based on an assumed normal year. For the 19-year period ending September 30,1914, the mean annual precipitation in western Oregon was below normal only once, and in the 10 years following 1914 it was above normal only twice. The potential power of the river is determined by the normal flow, whereas the capacity of steam auxiliary required depends on the flow of a dry year. The stream flow as given in Table 10 for the Kerby reservoir site, above Josephine Creek, was estimated from the records of discharge at Kerby for 1927 and 1928 and the records of precipitation. For the other sites on the Illinois River the stream flow was estimated from the flow at Kerby on the basis of comparative drainage areas. The drainage areas used for the computation are given in Table 11. General measurements of the drainage areas of the Rogue River and its principal tributaries are given in Table 12.

TABLE 10.-Eistimated natural-flow, in second-feet, of the Illinois River, Oreg.

\begin{tabular}{|c|c|c|c|c|c|c|c|c|c|}
\hline Month & Kerby & $\begin{array}{c}\text { Fall } \\
\text { Creek }\end{array}$ & $\begin{array}{l}\text { Clear } \\
\text { Creek }\end{array}$ & $\begin{array}{c}\text { Bald } \\
\text { Moun- } \\
\text { tain }\end{array}$ & Month & Kerby & $\begin{array}{c}\text { Fall } \\
\text { Creek }\end{array}$ & $\begin{array}{l}\text { Clear } \\
\text { Creek }\end{array}$ & $\begin{array}{c}\text { Baid } \\
\text { Moun- } \\
\text { tain }\end{array}$ \\
\hline $\begin{array}{l}\text { November } \\
\text { December } \\
\text { January } \\
\text { February } \\
\text { March } \\
\text { April }\end{array}$ & $\begin{array}{l}1,180 \\
1,810 \\
3,000 \\
1,400 \\
1,600 \\
1,500\end{array}$ & $\begin{array}{l}1,850 \\
2,850 \\
4,700 \\
2,200 \\
2,500 \\
2,400\end{array}$ & $\begin{array}{l}2,500 \\
3,800 \\
6,250 \\
2,900 \\
3,300 \\
3,100\end{array}$ & $\begin{array}{l}2,650 \\
4,100 \\
6,800 \\
3,200 \\
8,600 \\
3,400\end{array}$ & $\begin{array}{l}\text { May } \\
\text { June } \\
\text { July } \\
\text { August } \\
\text { September } \\
\text { October }\end{array}$ & $\begin{array}{r}700 \\
200 \\
100 \\
60 \\
50 \\
150\end{array}$ & $\begin{array}{r}1,100 \\
315 \\
160 \\
95 \\
79 \\
237\end{array}$ & $\begin{array}{r}1,450 \\
420 \\
210 \\
125 \\
104 \\
312\end{array}$ & $\begin{array}{r}1,600 \\
450 \\
200 \\
135 \\
112 \\
336\end{array}$ \\
\hline
\end{tabular}


TABLE 11.-Drainage areas and estimated discharge at power sites in the Rogue River Basin, Oreg.

Rogue River

\begin{tabular}{|c|c|c|c|c|}
\hline \multirow{2}{*}{ No. } & \multirow{2}{*}{ Name of site } & \multirow{2}{*}{$\begin{array}{c}\text { Drainage } \\
\text { area } \\
\text { (square } \\
\text { miles ) }\end{array}$} & \multicolumn{2}{|c|}{$\begin{array}{l}\text { Discharge * } \\
\text { (second-feet) }\end{array}$} \\
\hline & & & Q50 & Q90 \\
\hline $\begin{array}{r}1 \\
2 \\
3 \\
4 \\
5 \\
6 \\
7 \\
8 \\
9 \\
10 \\
11 \\
12 \\
13 \\
14 \\
15 \\
16 \\
17 \\
18 \\
19 \\
20 \\
21 \\
22 \\
23 \\
24 \\
25\end{array}$ & $\begin{array}{l}\text { Hamaker } \\
\text { Castle Creek } \\
\text { Union Creek } \\
\text { Top Creek } \\
\text { Riter Creek } \\
\text { Prospect } \\
\text { Lost Creek } \\
\text { Butte Creek } \\
\text { Trail Creek } \\
\text { Long Creek } \\
\text { Reese Creek } \\
\text { Little Butte Creek } \\
\text { Gold Hill } \\
\text { Rock Point } \\
\text { Savage Rapids } \\
\text { Ament } \\
\text { Hell Gate } \\
\text { Taylor Creek. } \\
\text { Swing Bridge } \\
\text { Horseshoe Bend. } \\
\text { Stairs Creek } \\
\text { Copper Canyon. }\end{array}$ & $\begin{array}{r}59 \\
187 \\
262 \\
312 \\
319 \\
\mathbf{5 7 7} \\
583 \\
685 \\
926 \\
926 \\
1,137 \\
1,137 \\
\mathbf{1}, 200 \\
1,580 \\
2,020 \\
2,050 \\
2,110 \\
2,390 \\
\mathbf{2}, 410 \\
\mathbf{3}, \mathbf{3 7 0} \\
\mathbf{3}, 390 \\
\mathbf{3}, 600 \\
\mathbf{3}, 680 \\
\mathbf{3}, 780 \\
4,870\end{array}$ & $\begin{array}{r}125 \\
375 \\
500 \\
575 \\
585 \\
1,330 \\
1,350 \\
1,400 \\
1,660 \\
1,660 \\
1,830 \\
1,830 \\
1,860 \\
2,000 \\
2,150 \\
2,190 \\
2,210 \\
2,340 \\
2,360 \\
2,950 \\
2,970 \\
3,130 \\
3,200 \\
3,250 \\
5,150\end{array}$ & $\begin{array}{r}80 \\
225 \\
290 \\
325 \\
330 \\
700 \\
775 \\
845 \\
990 \\
990 \\
1,100 \\
1,100 \\
1,120 \\
1,180 \\
1,180 \\
1,180 \\
1,200 \\
1,210 \\
1,210 \\
1,280 \\
1,290 \\
1,300 \\
1,330 \\
1,370 \\
1,490\end{array}$ \\
\hline
\end{tabular}

mlinois River

\begin{tabular}{|c|c|c|c|c|}
\hline $\begin{array}{l}34 \\
35 \\
36 \\
37\end{array}$ & $\begin{array}{l}\text { Kerby } \\
\text { Fall Creek } \\
\text { Clear Creek } \\
\text { Bald Mountain. }\end{array}$ & $\begin{array}{l}380 \\
600 \\
792 \\
856\end{array}$ & $\begin{array}{r}850 \\
1,330 \\
1,800 \\
1,910\end{array}$ & $\begin{array}{l}38 \\
60 \\
80 \\
85\end{array}$ \\
\hline
\end{tabular}

- With no allowance for diversions by Eagie Point and Grants Pass Irrigation Districts.

- Area given is based on the assumption that Mill Creek, Red Blanket Creek, and the Middle and south Forks of the Rogue River will be diverted to the Rogue River above Prospect Dam.

TABLE 12.-Drainage areas of 'the Rogue River and its tributaries, Oreg.

\begin{tabular}{|c|c|c|}
\hline Stream & Point of measurement & $\begin{array}{c}\text { Area } \\
\text { (square } \\
\text { miles) }\end{array}$ \\
\hline 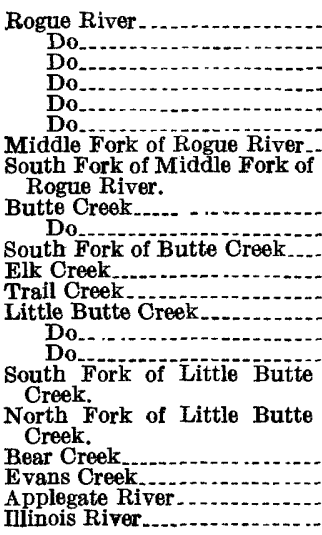 & 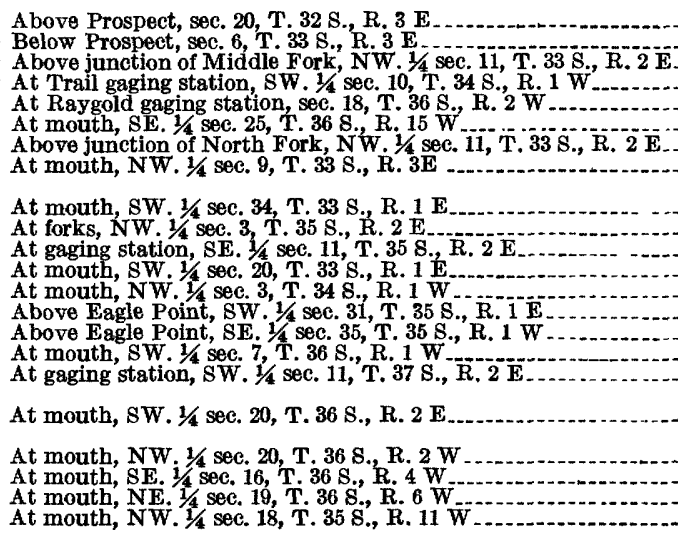 & $\begin{array}{r}315 \\
378 \\
386 \\
1,110 \\
2,029 \\
5,080 \\
240 \\
93 \\
\\
245 \\
166 \\
113 \\
128 \\
61 \\
276 \\
284 \\
361 \\
110 \\
49 \\
49 \\
380 \\
222 \\
768 \\
995\end{array}$ \\
\hline
\end{tabular}


TABLE 13.-Gaging stations in the Rogue River Basin, Oreg.

\begin{tabular}{|c|c|c|}
\hline $\mathrm{n}$ & Location & Period of record \\
\hline 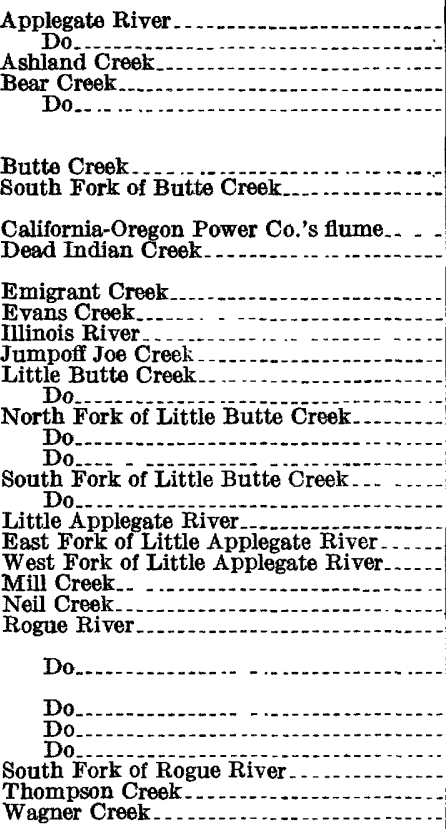 & 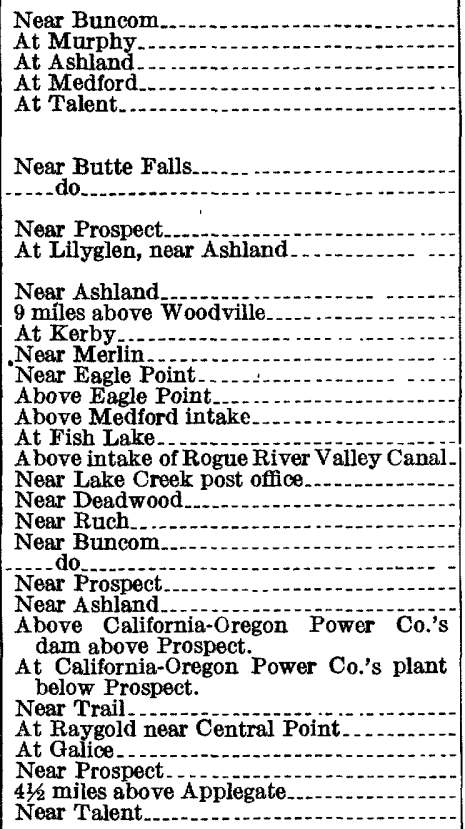 & $\begin{array}{l}1911-1914 \\
1907-1910 . \\
1913 \text { (5 months). } \\
1915- \\
1907-1911,1912, \\
1913,1914,1921, \\
\text { (parts of years) } \\
1918-1920 . \\
1910-11,1915 \\
1917- \\
1913- \\
1916-1919 \text { (parts } \\
\text { of years). } \\
1920- \\
1913 \text { (4 months). } \\
1927- \\
1922 \text { (8 months). } \\
1907-1916 . \\
1916- \\
1911-1913,1922- \\
1914- \\
1916-1919,1921- \\
1910-1913,1921- \\
1917-18 . \\
1913 \text { (6 months). } \\
\text { Do. } \\
\text { Do. } \\
1910 \text { (2 months). } \\
1913 \text { (5 months). } \\
1907-1912,1923- \\
1913- \\
1910-1913 \text {. } \\
1905- \\
1906 . \\
1924- \\
1913 \text { (5 months). } \\
1913 \text { (3 months). }\end{array}$ \\
\hline
\end{tabular}

\section{FLOODS}

The following table shows the greatest recorded discharge at gaging stations on the Rogue River:

Maximum recorded discharges in the Rogue River Basin

\begin{tabular}{|c|c|c|c|}
\hline Locality & Date & $\begin{array}{c}\text { Drainage } \\
\text { area } \\
\text { (square } \\
\text { miles) }\end{array}$ & $\begin{array}{l}\text { Greatest } \\
\text { recorded } \\
\text { discharge } \\
\text { (second- } \\
\text { feet) }\end{array}$ \\
\hline $\begin{array}{l}\text { Above Prospect. } \\
\text { Below Prospect... } \\
\text { At Raygold }\end{array}$ & $\begin{array}{l}\text { Nov. 22, } 1909 \\
\text { Dec. 30, } 1925 \\
\text { Nov. 23, } 1909\end{array}$ & $\begin{array}{r}315 \\
378 \\
2,020\end{array}$ & $\begin{array}{r}9,300 \\
8,180 \\
60,000\end{array}$ \\
\hline
\end{tabular}

The maximum discharge above Prospect and at Raygold during the flood of November, 1909, varied almost exactly in the ratio of the drainage areas. If this held true at the mouth of the Rogue River the maximum flow at that point amounted to 150,000 second-feet. In general the flood flow in second-feet per square mile decreases with the increase in drainage area. But there is a possibility that the flood flow from the lower tributaries is at least as great and possibly greater than the flood flow from the upper river, for the lower basin is rocky, with steep slopes, and probably receives a heavy rainfall during flood 
periods. Drift on the banks of the river at Copper Canyon indicates that flood flows reach a stage 30 to $\mathbf{4 0}$ feet above low water. Undoubtedly large flood flows can be expected at the Copper Canyon dam site and comparatively large flows at sites above the mouth of the Illinois River. The flood flow at Raygold gives an idea of the flows to be expected above the mouth of the Applegate River.

After the construction of the Kerby Reservoir on the Illinois River peak flows on that stream will be largely ironed out, and this will aid materially at the Copper Canyon site. The Kerby Reservoir will probably be built before any plants on the Illinois River are constructed.

\section{PRIOR WATER RIGHTS}

A considerable area in the Rogue River Basin is irrigated, but except for the large tract in the vicinity of Grants Pass, the water is almost entirely supplied by the side streams. The greater use of water for irrigation toward the later part of the period from 1906 to 1924 had no marked effect on the discharge at Raygold and at points above, and it is probable that in the future the effect will not differ much from that in the past, except possibly that the diversion of 75 secondfeet from Butte Creek at Butte Falls, Oreg., into the Little Butte Creek drainage basin may decrease the low flow below the mouth of Butte Creek by approximately that amount.

The Grants Pass Irrigation District has a dam and pumping plant in the Rogue River at Savage Rapids (see pl. 19, $A$ ), about 6 miles above Grants Pass, at which two pumping lifts and a gravity canal are in use. One of the pumps delivers 40 second-feet to a canal 150 feet above the pond level; the other delivers 67 second-feet to a canal 90 feet above the pond; and the gravity ditch will carry about 150 second-feet. The total drain on the river is about 260 second-feet during the height of the irrigation season. It seems reasonable to assume that some of this water will return to the river. If 60 secondfeet is so returned the decrease in the Q90 flow during the season of low flow will be about 200 second-feet.

As the tributary streams in the agricultural part of the basin are largely used for irrigation at present, their Q90 flow is very low. This fact has been taken into account in estimating their contribution to the flow of the main river.

Considerable water is diverted for irrigation from the East and West Forks of the Illinois River above Kerby and from Deer Creek. These diversions seriously affect the low-water flow during the summer, but with the flow regulated by the Kerby Reservoir the effect on the yearly run-off would be slight and is probably included in the estimated discharge. 


\section{RIVER CONTROL}

As there is sufficient water in the Rogue River, even during periods of low flow, to satisfy all irrigation needs, regulation of the discharge would be of no material benefit to agriculture. In the interest of power development, however, the increase of the low flow is greatly to be desired, for the amount of firm power that can be produced at all the plants in the basin is dependent on the flow available during the low period, and any increase in this flow will add greatly to the sale value of the produced power. On the Illinois River the period of low precipitation in the summer is a period of very low flow. This long period of low flow would render power development unprofitable without storage.

Four reservoir sites were surveyed-the Hamaker, Lost Creek, and Taylor Creek sites, on the Rogue River, and the Kerby site, on the Illinois River. Another possible reservoir site on the Applegate River was inspected. They are described on pages 58-66. At some of the high dams in the canyon section of the Rogue River ponds of large area will be created, and by their proper manipulation the low flow may be still further increased.

A study of the run-off records of the Rogue River at Raygold shows that a reservoir having a capacity of about 400,000 acre-feet would be necessary to equalize the flow for the normal year. As no site for a reservoir or combination of reservoirs with a capacity so great exists above Raygold, complete regulation can never be attained. Computations made from the hydrograph of the flow at the gaging station above Prospect indicate that a reservoir having a capacity of about 80,000 acre-feet would provide complete regulation during a normal year, whereas to obtain the desired result at the gaging station below Prospect a capacity of 114,000 acre-feet would be required.

To maintain the present Q50 flow through the low season at Raygold would require a reservoir with a capacity of 200,000 acre-feet; above Prospect, 22,000 acre-feet; and below Prospect, 43,000 acre-feet.

The Taylor Creek reservoir site on the Rogue River below Grants Pass, if developed, would provide complete regulation of the flow below the dam, but the land that would be flooded is mostly cultivated and irrigated, and its use for storage can not be economically justified. Below this point there are no sites valuable primarily for storage, but the upper portion of the ponds created by the power dams may be used to regulate the flow in part.

Regulation of the flow of the Illinois River for power in a normal year would require about 475,000 acre-feet of storage in the Kerby reservoir. This could be provided by a dam raising the water to the 1,360 -foot contour. In addition to the storage in the Kerby Reservoir, the ponds above proposed power dams on the Illinois River would afford some storage by drawing down the head. At Fall Creek, 
with a dam 180 feet high, a drawdown of 40 feet would yield 20,000 acre-feet of storage. At Clear Creek a drawdown of 40 feet would yield 16,500 acre-feet of storage, and at Bald Mountain a drawdown of 40 feet would yield 15,000 acre-feet of storage. In computing the potential power at the several sites it has been assumed that in a normal year all of this storage capacity would be used. It has been assumed also that the power plants on the Illinois River would be operated in a single system and the flow regulated to give the maximum continuous output.

\section{STORAGE STTES}

There are no developed storage sites in the Rogue River Basin. The undeveloped sites are described below:

\section{HAMAKER RESERVOIR SITE (12RD 1)}

At Hamaker Meadows, in secs. 20 and 21, T. 29 S., R. 4 E., about 2 miles above National Creek, there is a possible storage site. (See fig. 8 and pl. 11, B.) The bottom lands are relatively flat and marshy and act as a reservoir in their present state. The flow at the site is estimated at 125 second-feet for 50 per cent of the time and 80 second-feet for 90 per cent of the time. The total annual discharge in a normal year is estimated at 102,000 acre-feet, which is equivalent to a continuous flow of 140 second-feet.

The altitude of the water surface at the dam site is about 3,739 feet, and a dam 160 feet high, or to the 3,900-foot contour, would be necessary to give maximum results for storage at this site. The exact height to which it would be possible to build a dam depends on the conditions disclosed by drilling.

The capacity curve shows that by flooding to the 3,900-foot contour a capacity of 21,000 acre-feet would be made available. While this volume is not quite sufficient to make the Q50 and Q90 flows above Prospect equal, it will increase the Q90 flow by 95 second-feet and will contribute even more to the extreme low flow. This amount of stored water if used through a head of 2,750 feet at proposed power sites lower down at 70 per cent efficiency would generate $42,000,000$ kilowatt-hours. This is, therefore, a valuable reservoir site, and the expenditure of considerable money in the construction of a dam would be justified.

In estimating the potential power of the river, it has been assumed that a dam can be built to the full height of 160 feet, but because of geologic conditions this may not be possible. Most of the reservoir site is clad with timber and dense underbrush. So thickly is the ground covered with the brush and fallen trees that it took 3 hours to walk 3 miles. This condition greatly hampered geologic examination of the site, and time was not available for a detailed study; but sufficient evidence was found in the afternoon spent there to indicate that the site should not be developed without an intensive study of the geology and without thorough drilling and numerous porosity tests.

The reservoir site consists of marshy bottom land bordered on both sides by the pumice-covered banks of the Rogue River. No bedrock was positively identified in the reservoir floor. Numerous subangular boulders indicate that a deposit of glacial débris covers the valley floor; its relation to the pumice was not determined.

Along one side of the bottom land and in places on both sides there is a bench of ash and pumice which slopes steeply to the river. In a few places these slopes become vertical cliffs nearly 200 feet high which expose unstratified ash and pumice devoid of vegetation. A number of the exposures were examined, and 

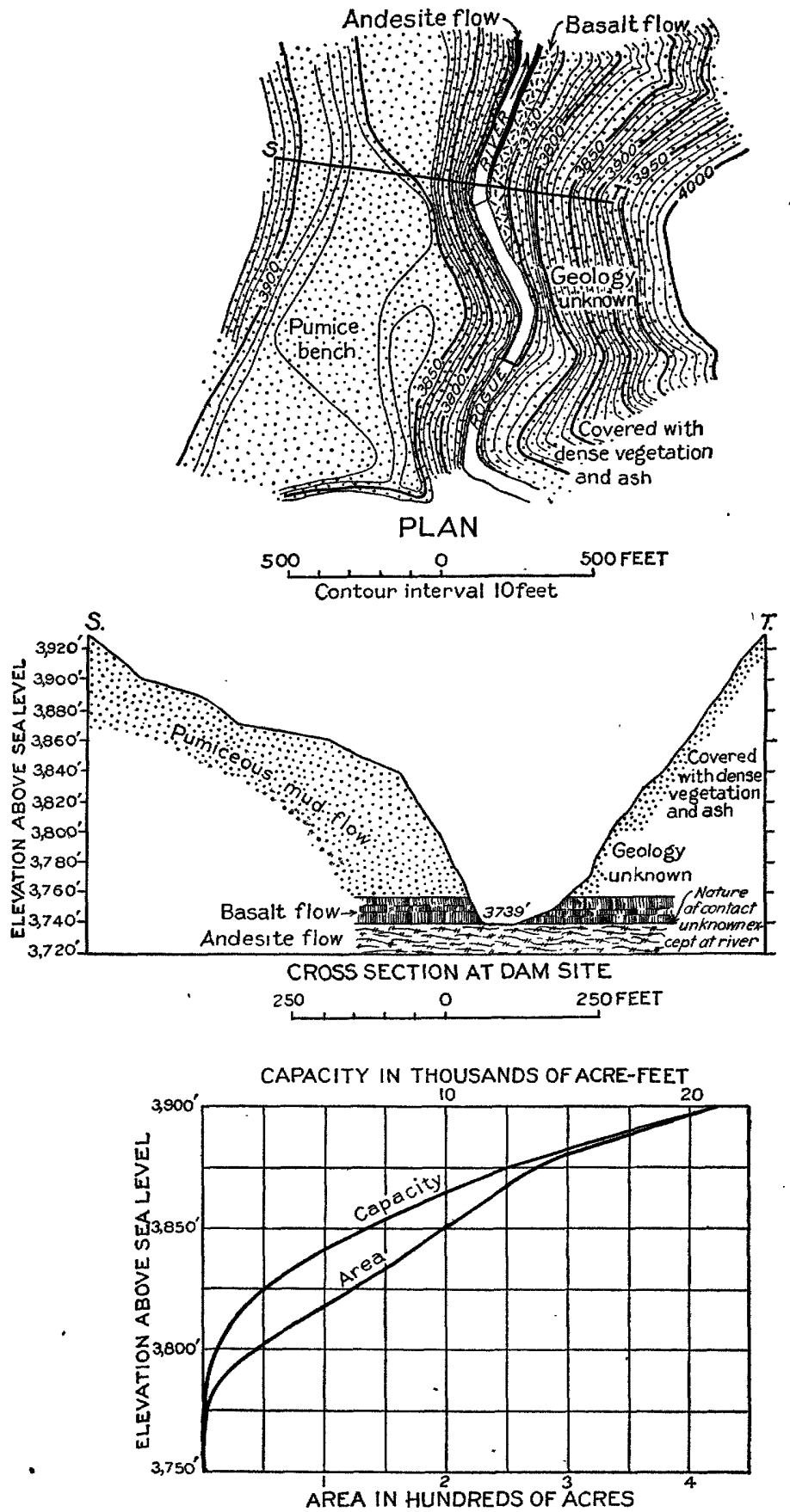

FigURE 8.-Plan, cross section, and area and capacity curves, Hamaker reservoir site, Rogue River Basin 
in only one place were there any boulders other than pumice. At this place a long lens of cobbles and subangular lava rock having a maximum thickness of 3 feet was visible. It doubtless represents the coarse deposit of some ancient stream. With this exception the outcrops consist entirely of white and gray pumice not even crudely stratified, for boulders of pumice 6 and 8 inches in diameter are commonly scattered throughout the finer ash. This deposit is compact at the base but appears looser at the top. It is quite evident that the pumice of the bench owes its thickness not to quiet subaerial deposition as a result of an explosive volcanic eruption, but to a mud flow. (See p. 43.) The ancient valley at the Hamaker reservoir site was wide and was left nearly filled with the mud. Subsequent erosion carved out another wide valley but left remnants of the mud flow as terraces along the valley wall.

Numerous small springs issue at the base of some of the pumice cliffs on the east side of the reservoir site. Although their total visible flow does not exceed 1 second-foot, they indicate that the pumice is permeable. The large springs that issue from the pumice deposits near Crater Lake also afford ample evidence that the pumice is extremely permeable. The occurrence of this immense permeable pumice deposit is an advantage in the reservoir as a place for underground storage, but at the dam site it may mean failure for a dam of the proposed height. The geology of this site is described further on page 72 .

\section{LOST CREER RESERVOIR STTE (12RD 8)}

The Lost Creek reservoir site is in secs. 24 and 26, T. 33 S., R. 1 E., and secs. 19 and 20, T. 33 S., R. 2 E., nearly 3 miles northeast of McLeod Bridge, on the Rogue River. (See fig. 9 and pl. 13, A.) The Crater Lake Highway crosses a part of the proposed reservoir floor. A 170-foot dam to flood to the 1,745-foot contour would create a reservoir with a surface of about 1,400 acres and a capacity of 110,000 acre-feet, with a drawdown of 125 feet.

At this site the Rogue River occupies an open valley. The flood plain has a maximum width of nearly three-quarters of a mile at the mouth of Lost Creek, which enters the north side of the valley half a mile above the dam site. The flood plain is 1,600 feet in altitude and is bordered at the mouth of Lost Creek and on the south side of the river by a flat-topped terrace of pumice that is 100 feet above the flood plain and in places over a quarter of a mile wide. In the $\mathbf{S} .1 / 2$, sec. 24, T. 33 S., R. 1 E., this terrace ends abruptly against another that has an altitude of about 1,820 feet, or 220 feet above the flood plain. East of the dam site the higher terrace is about half a mile wide and consists of soil-covered intracanyon basalt. The geologic relations and the character of the basalt are described further on pages 43 and 76.

During the glacial epoch the valley of the Rogue River was filled with débris to a depth of about 20 feet. Later erosion has left, a stony channel bordered on both sides by low terraces of sand and gravel a few feet above the river.

The surface area of the reservoir when full would be about 1,400 acres, and if a 3-foot evaporation and seepage loss over this entire area is assumed, the total loss from these causes would be 4,200 acre-feet. The reservoir capacity at the 1,620 -foot contour is only 4,000 acre-feet, and this lower portion will be maintained to give a power head. By allowing the reservoir to fluctuate between the 1,745-foot and 1,620-foot levels 110,000 acre-feet will be made available for regulation.

The gross head at proposed sites below Lost Creek amounts to 1,141 feet, and 110,000 acre-feet of water used through such a head would produce $75,000,000$ kilowatt-hours of energy. By using this capacity to partially equalize the flow at Raygold and by taking advantage of the release of stored water from the 

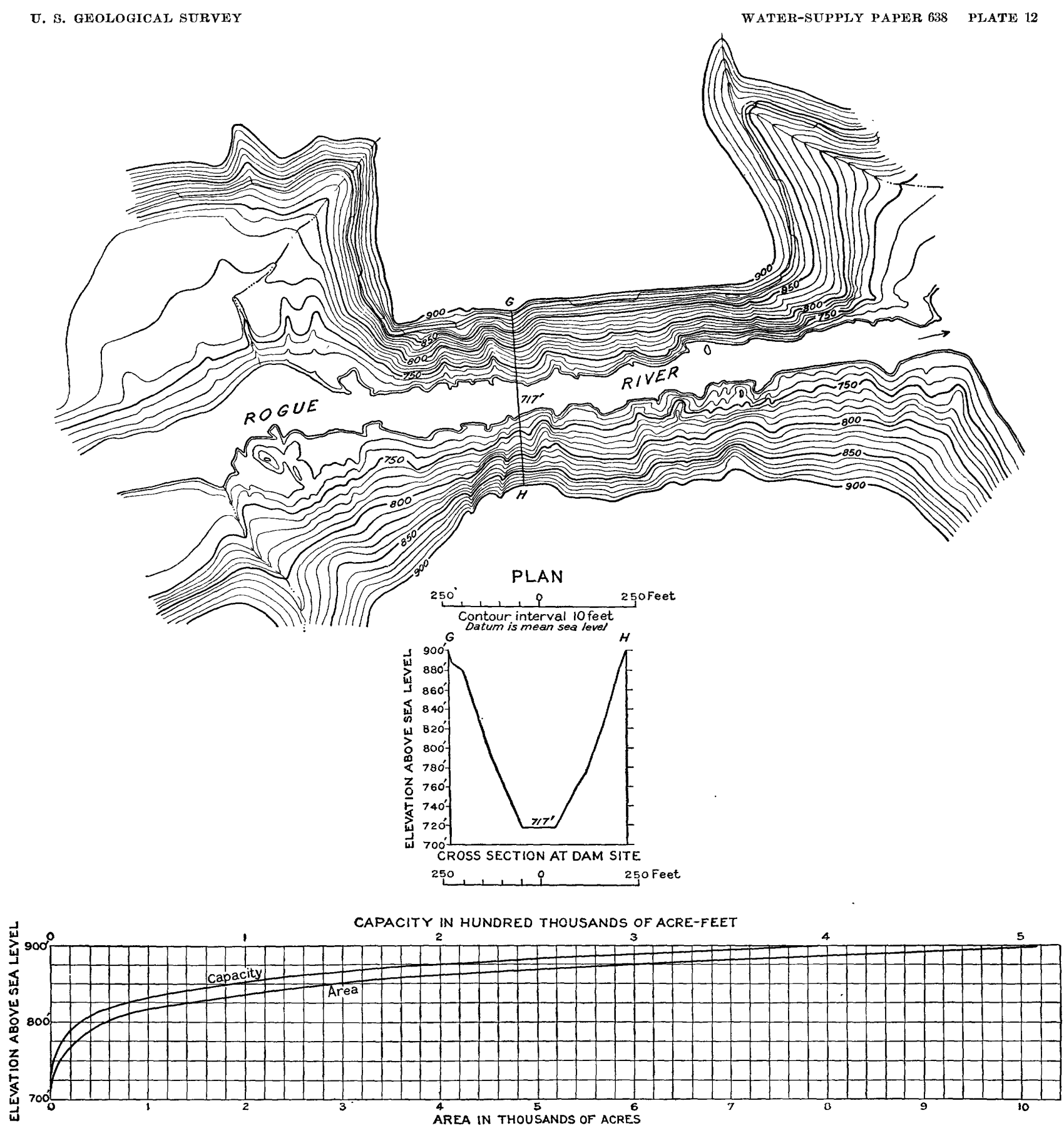

PLAN, CROSS SECTION, AND AREA AND CAPACITY CURVES, TAYLOR CREEK RESERVOIR SITE, ROGUE RIVER BASIN 



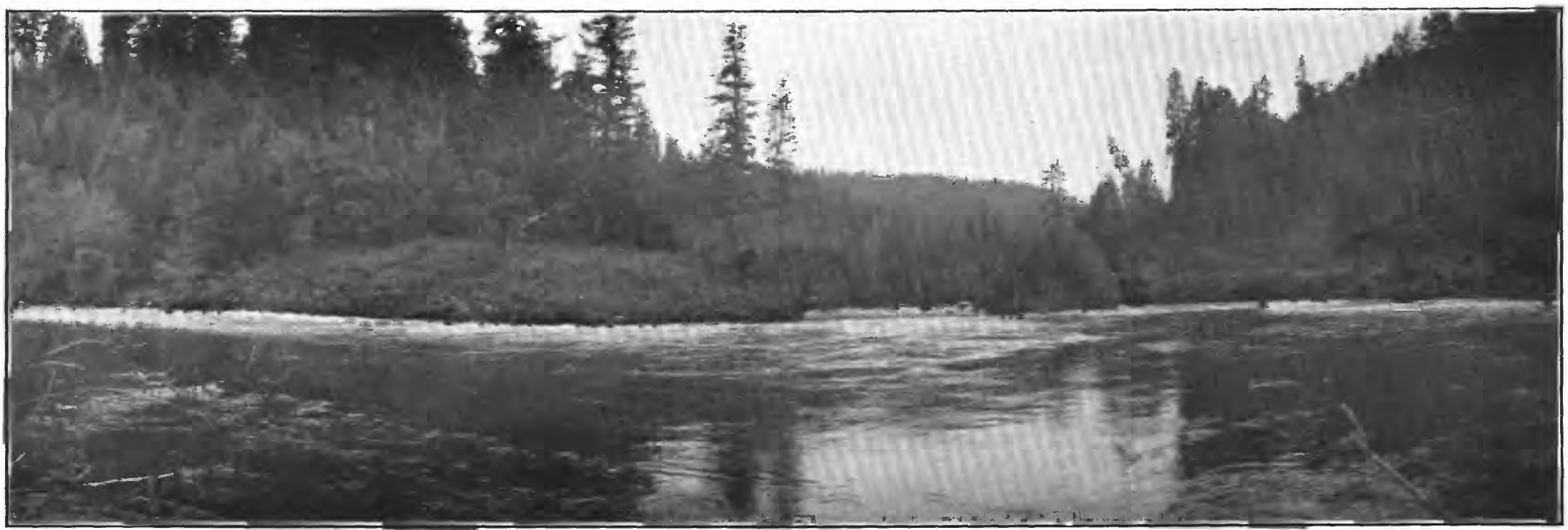

A. LOST CREEK DAM SITE, ROGUE RIVER BASIN

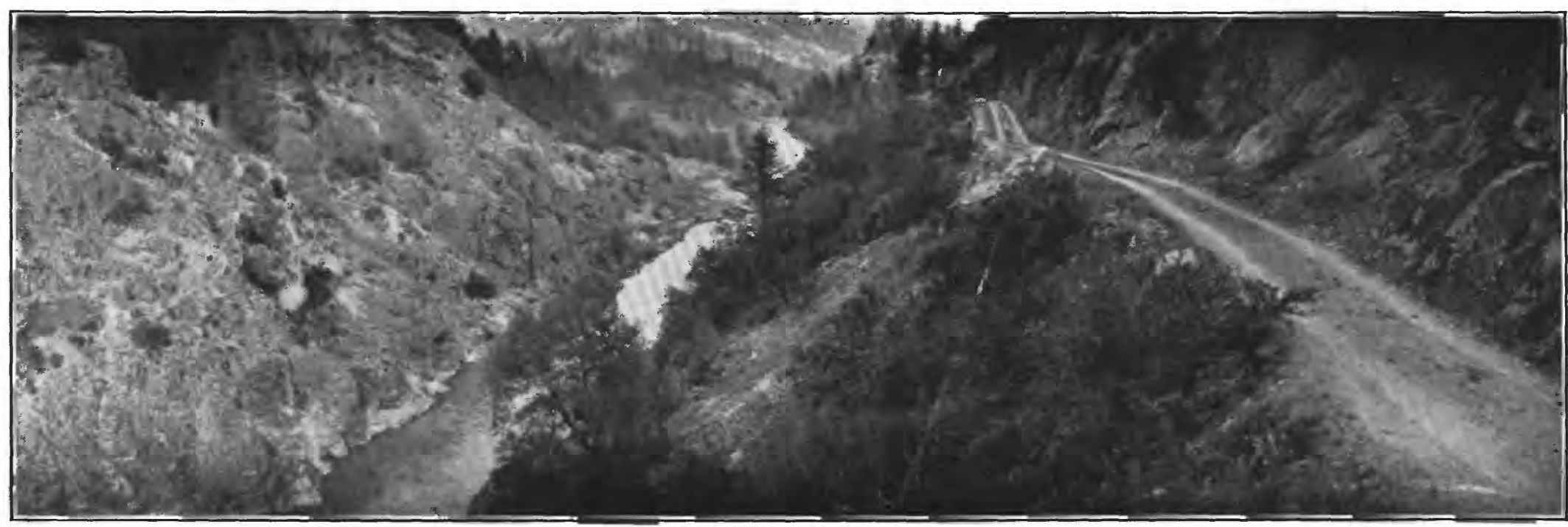

B. TAYLOR CREEK DAM SITE, ROGUE RIVER BASIN 
Hamaker Reservoir, the total increase in the Q90 flow at Raygold and all points below would be 560 second-feet.
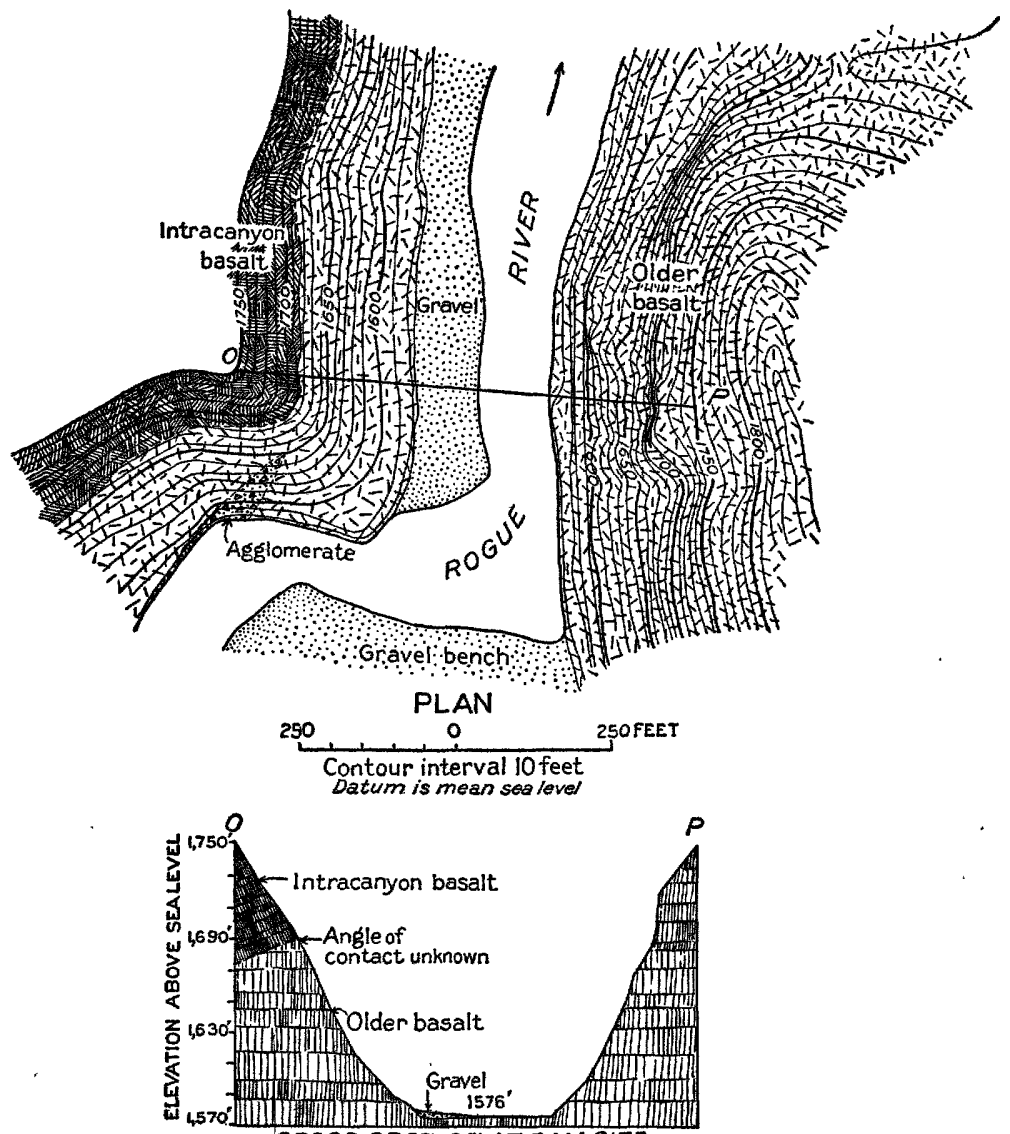

CROSS SECTION AT DAM SITE

250

250 FEET

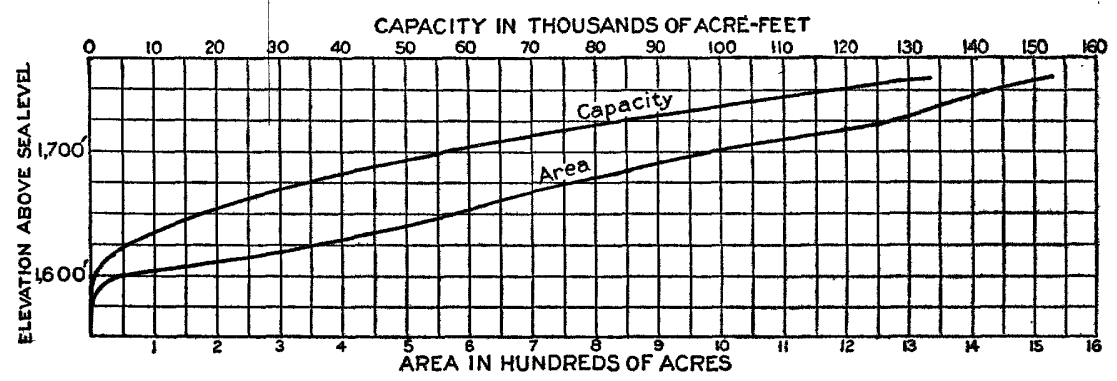

Figure 9.-Plan, cross section, and area and capacity curves, Lost Creek reservotr site, Rogue River Basin

The proposed reservoir would flood some bottom lands that are now cultivated and irrigated, and it would also necessitate the moving of a few houses and the relocation of a part of the Crater Lake Highway. The soil is mostly a volcanic 
ash, and owing to its distance from any large market its agricultural value is low. The hillsides are covered with timber and brush.

\section{TAYLOR CREEK RESERVOIR SITE (12RD 20 ATD 21)}

Below the town of Grants Pass there is an exceptionally good reservoir site on the Rogue River, with two good dam sites-the Hell Gate dam site, in sec. 10, T. 35 S., R. 7 W. (pl. 14, B), and the Taylor Creek dam site, in sec. 5, T. 35 S., R. 7 W. (pls. 12 and 13, B). A dam at either Hell Gate or Taylor Creek would flood this reservoir site. The open upper end of the site is Pleistocene gravel and sand underlain by ancient metamorphic and intrusive rocks consisting of schist, argillite, conglomerate, and serpentine. All the rocks observed in the site are relatively impermeable, so that no seepage from the reservoir is likely. Whereever the structure was observed the beds dip upstream, hence any leakage due to structure will be slight. So far as physical characteristics go no better reservoir could be desired, as the capacity increases rapidly with the height, and the hard, dense rock affords a foundation for a dam of any practicable height.

This site, however, is located in the heart of the agricultural part of the basin. A large part of the lands below the 900 -foot contour are cultivated and irrigated, and some of them are devoted to such specialized crops as orchards and hops. The market price for land that would be flooded is out of proportion to the power benefits that would be derived from stream regulation, and it is extremely improbable that the site will ever be developed for storage. The power possibilities are considered on page 84 .

\section{APPLEGATE RESERVOIR STTE (12RD 32)}

A possible reservoir site on the Applegate River with the dam site in sec. 15, T. 37 S., R. 6 W. (see fig. 10 and pl. 15, B), is shown on the Grants Pass topographic map. By raising the water 135 feet at the dam a reservoir with a capacity of 195,000 acre-feet would be formed. The total annual discharge of the Applegate River at Murphy in 1908, a year when the precipitation was only slightly above normal, was 428,000 acre-feet, equivalent to a continuous flow of 591 second-feet.

The reservoir floor consists of alluvial deposits in which rock outcrops are rare. A study of the rocks of the adjacent area indicates that the site is probably underlain by impermeable intrusive rocks. The dam site is wide, and the river bed and both abutments are composed of stratified. sand and gravel of unknown thickness. Bedrock is nowhere exposed in the site. In places large angular rocks that appear to have fallen from Eagle Mountain occur in the alluvium. There is a pronounced bench on the south side, and a dry gulch 20 feet deep that has been cut in this bench does not expose bedrock. The depth to bedrock can be determined only by drilling. A reconnaissance indicates that bedrock may lie more than 25 feet below the surface along the entire line of the dam and may be considerably more in places. The dam will have to be anchored on bedrock in order to prevent seepage through the alluvium and will be expensive because of the wide section and great depth to bedrock, but the site is believed to be physically feasible and may be utilized if the cost of construction does not exceed the value of the storage and power derived from its development.

A considerable portion of the bottom lands which would be flooded by this reservoir are sandy and practically worthless for agriculture. Other parts are cultivated and irrigated, and these tracts, together with the settlements of Newhope and Murphy, would be inundated. It would also be necessary to relocate a considerable mileage of highway and to move or destroy many isolated buildings. 
The gross head at proposed sites below this reservoir, including the head that could be developed at the Applegate Dam, amounts to 765 feet. On the assump-

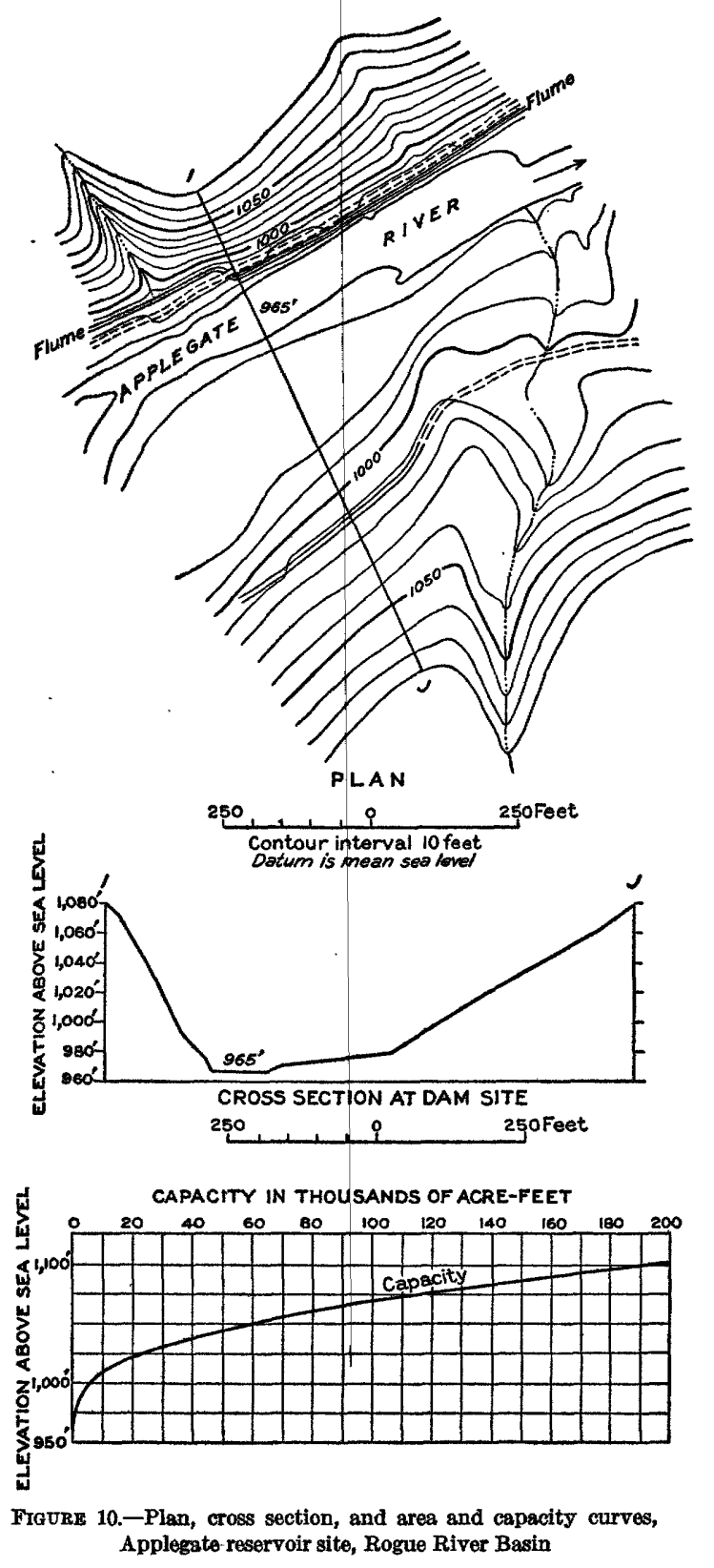

tion that 10,000 acre-feet would be left in the reservoir to create head for power, the remaining 185,000 acre-feet would produce $102,000,000$ kilowatt-hours of power. In addition to the power obtained from the stored water considerable 
power could be developed at the dam from the natural flow. So, although the cost of this reservoir would be high, yet after the Rogue River is developed this storage would be very valuable.

\section{KERBY RESERVOIR SITR (18RD 84)}

The proposed Kerby Reservoir, on the Illinois River, would be used principally for storage, but some power could also be obtained. (See fig. 11 and pls. 14, $A$, $15, A$, and 16, A.) The dam would be built at one of two sites above Josephine Creek, in sec. 29, T. 38 S., R. 8 W., the choice depending on conditions shown by borings and test pits. Surface conditions indicate that the yardage would be the same at the two sites, for a dam at the lower site, though higher, would be shorter. A dam raising the water level to the 1,320-foot contour would flood 4,910 acres and afford a capacity of 219,000 acre-feet. If the water level were raised 40 feet higher, to the 1,360-foot contour, it would flood about 8,400 acres and afford a capacity of 475,000 acre-feet. A dam at the upper site to flood to the 1,360 -foot contour would need to be 160 feet above the water surface; a dam at the lower site would need to be $\mathbf{1 2}$ feet higher. The total annual discharge in a normal year at these sites is estimated at 708,000 acre-feet, equivalent to a continuous flow of $\mathbf{9 7 0}$ second-feet. This estimate is probably conservative, as the actual discharge in 1927 amounted to $1,250,000$ acre-feet and in 1928 to 741,000 acre-feet. Conditions at both dam sites appear good for any type of dam. The river flows over bedrock, and probably the amount of surface stripping along the sides of the canyon would not be excessive. The spillway would be an open cut in the rock on one side of the dam. A railroad extends within 15 miles of the dam site and a good road within 3 miles. The damages would consist in flooding 8,400 acres of land and the small town of Kerby. As-the land is sandy and of little agricultural value it should be purchasable at a price that would make the project feasible.

The reservoir site is covered over most of its area with alluvium and elsewhere with a thick mantle of soil, except in the vicinity of the dam sites, where numerous outcrops of serpentine occur. On the north a low divide 4 miles wide separates the Illinois River from Deer Creek. If the water level should be raised to the 1,360 -foot contour it would lie not far from the crest of this divide. Consequently the divide was examined for possible leakage. Artificial cuts expose thin-bedded shales that are contorted and steeply dipping but sufficiently impermeable to prevent seepage toward Deer Creek. The remainder of the reservoir site was not examined in detail, because the struoture at the dam site indicates that there will be no seepage from the underlying rocks.

The upper Kerby dam site is in the SE. $1 / 4$ sec. 29 , T. 38 S., R. 8 W., on the Illinois River, on the south side of Eight Dollar Mountain. (See pl. 16, A.) The mountain is part of an immense body of serpentine and peridotite-altered intrusive basic rock-that strikes northeast. This rock forms both abutments of the site. Such rock is impermeable, and as it extends to great depth, it acts as a cut-off wall, preventing any seepage through the sedimentary beds that underlie the reservoir site. Along the line of the dam massive peridotite crops out, but in most places it is covered with considerable rotten rock and soil, so that more stripping will be necessary at this site than at the lower Kerby dam site. Otherwise the site is satisfactory.

The lower Kerby or Josephine Creek dam site is in the NW. 1/4 sec. 29, T. 38 S., R. $8 \mathrm{~W}$., on the Illinois River, almost a mile downstream from the upper site. (See pl. 14,A.) Massive peridotite with seams of serpentine crops out on both banks and in the river bed at this site. Rock in place is exposed on the west side for a long distance up the mountain; on the east side the outcrop can 
be traced for a distance of about 25 feet above the river surface, and above this point the surface is strewn with loose blocks of the same rock. About 50 feet upstream from the dam site there is an 8-foot dike of a rock containing black crystals in a gray groundmass; it is apparently allied to a diorite. The lower site has all the advantages of the upper site and would require much less exca-
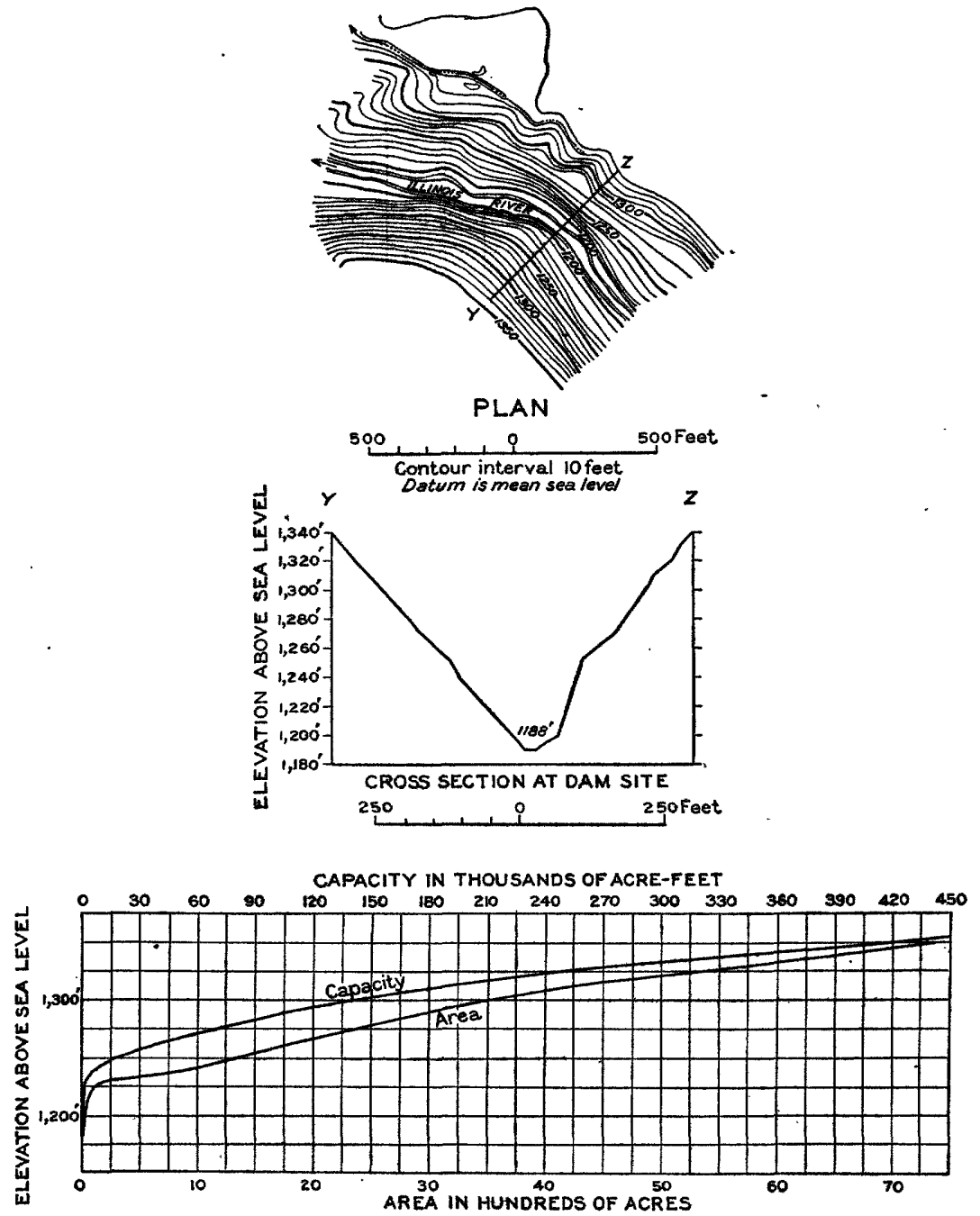

Frgure 11.-Plan, cross section, and area and capacity curves, Josephine Croek dam site and Kerby reservoir site, Rogue River Basin

vation for the dam. It would be profitable to explore both sites and also the area between them with a drill to determine the best place for a dam of the type to be constructed.

The value of the power sites below on the Illinois River depends upon the construction of the Kerby Reservoir. 
SUMMARY OF RBSULTS FROM STORAGR ON THE ROGUE RIVER

Table 14 shows for the normal year the Q50 and Q90 flows under various assumptions at the proposed power plants.

TABLE 14.-Summary of results from storage on the Rogue and Applegate Rivers, Oreg., in second-feet

\begin{tabular}{|c|c|c|c|c|c|c|c|}
\hline \multirow[t]{2}{*}{ No. } & \multirow[t]{2}{*}{ Name of site } & \multicolumn{2}{|c|}{ Existing flow } & \multicolumn{2}{|c|}{$\begin{array}{l}\text { Prospective flow } \\
\text { with partial reg- } \\
\text { ulation }\end{array}$} & \multicolumn{2}{|c|}{$\begin{array}{l}\text { Prospective flow } \\
\text { with regulation } \\
\text { including Apple } \\
\text { gate storage res } \\
\text { ervoir }\end{array}$} \\
\hline & & Q50 & Q90 & Q50 & Q90 & Q50 & Q90 \\
\hline \begin{tabular}{r|}
1 \\
2 \\
3 \\
4 \\
5 \\
6 \\
7 \\
8 \\
9 \\
10 \\
11 \\
12 \\
13 \\
14 \\
15 \\
16 \\
17 \\
18 \\
19 \\
20 \\
21 \\
22 \\
23 \\
25
\end{tabular} & 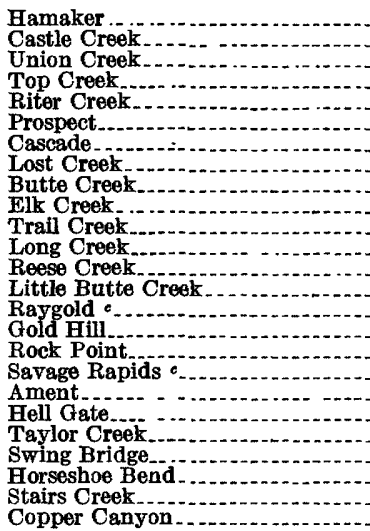 & $\begin{array}{r}125 \\
375 \\
500 \\
575 \\
585 \\
1,330 \\
1,350 \\
1,400 \\
1,660 \\
1,660 \\
1,860 \\
1,860 \\
1,900 \\
2,030 \\
2,150 \\
2,190 \\
2,210 \\
2,340 \\
2,360 \\
2,950 \\
2,970 \\
3,130 \\
3,200 \\
3,250 \\
5,150\end{array}$ & $\begin{array}{r}80 \\
225 \\
290 \\
325 \\
330 \\
700 \\
775 \\
845 \\
920 \\
920 \\
1,030 \\
1,030 \\
1,050 \\
1,110 \\
1,110 \\
1,110 \\
1,130 \\
930 \\
930 \\
1,010 \\
1,020 \\
1,030 \\
1,060 \\
1,100 \\
1,220\end{array}$ & 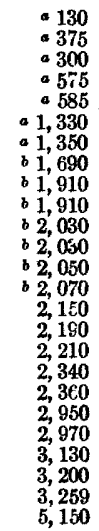 & $\begin{array}{l}\text { a } 130 \\
\text { a } 270 \\
\text { a } 344 \\
\text { a } 385 \\
\text { a } 386 \\
\text { a } 795 \\
\text { b } 870 \\
\text { b } 1,140 \\
\text { b } 1,240 \\
\text { b } 1,240 \\
\text { b } 1,400 \\
\text { b } 1,420 \\
\text { b } 1,430 \\
\text { b } 1,650 \\
\text { b } 1,670 \\
\text { b } 1,670 \\
\text { b } 1,690 \\
\text { b } 1,490 \\
\text { b } 1,490 \\
\text { b } 1,570 \\
\text { b } 1,580 \\
\text { b } 1,590 \\
\text { b } 2,620 \\
\text { b } 1,660 \\
\text { e } 4,000\end{array}$ & 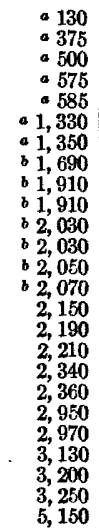 & $\begin{array}{r}\text { a } 130 \\
\text { a } 270 \\
\text { a } 344 \\
\text { a } 385 \\
\text { a } 386 \\
\text { a } 795 \\
\text { a } 870 \\
\text { b 1, 140 } \\
\text { b 1, 240 } \\
\text { b } 1,240 \\
\text { b } 1,400 \\
\text { b } 1,220 \\
\text { b } 1,430 \\
\text { b } 1,650 \\
\text { b } 1,670 \\
\text { b } 1,670 \\
\text { b } 1,690 \\
\text { b } 1,490 \\
\text { b } 1,490 \\
\text { d } 2,390 \\
\text { d } 2,400 \\
\text { d } 2,410 \\
\text { d } 2,440 \\
\text { d } 2,480 \\
\text { e } 4,850\end{array}$ \\
\hline
\end{tabular}

- Flow as modified by use of Hamaker Reservoir to regulate discharge above Prospect.

b Flow as modified by use of Hamaker Reservoir to regulate discharge above Prospect and by use of Lost Creek Reservoir to regulate discharge at Raygold.

- Developed site.

¿ Hamaker and Lost Creek Reservoirs used as above. Applegate Reservoir used for regulating flow at Hell Gate and below.

- Flow as modified by use of Kerby Reservoir to regulate flow of the mlinois River.

The storage that could be obtained at power sites on the lower Rogue River by manipulating the pond level is discussed under those sites.

\section{WATER POWER}

The Rogue River has a well-sustained low flow, which can be somewhat supplemented by the use of the four reservoirs above described. At many points the fall is concentrated, and there are numerous good dam sites. (See pls. 3 and 4.) A large proportion of the available power can be produced without materially damaging existing or proposed improvements. Construction-plant equipment and material can be carried by existing transportation routes except in the canyon section of the river, where special methods will have to be used.

In spite of the well-sustained flow of some of the creeks tributary to the Rogue River it is not considered probable that any of those above Prospect are worthy of development by themselves except for 
some special local use, because of the low slope in their lower stretches and because of the more advantageous possibilities on the main river.

Mill Creek, Red Blanket Creek, and the Middle and South Forks of the Rogue River, which flow into it just below Prospect, are all valuable power streams and can be developed separately. It appears preferable, however, that they should be combined into some unified system, and such a system is considered in detail in connection with the Prospect power site. (See pp. 68-69.) Briefly, it consists in collecting the flow of these four tributaries and turning it into the main river above the section of greatest fall. Such a method will utilize the valuable part of Mill and Red Blanket Creeks and the lower part of the Middle and South Forks. On the Middle and South Forks the parts above the diversion dams suggested have further attractive power possibilities.

As Butte Creek drains a heavily timbered region in which there are numerous springs, the low flow is well sustained. At Butte Falls the discharge available for 90 per cent of the time is about 100 second-feet, and the average grade of the creek between this point and the Rogue River is 60 feet to the mile. The construction of a diversion dam and canal would involve no particular difficulty. The power value of this section of the stream is, however, destroyed by the diversion of practically all the low flow for irrigation. The Eagle Point Irrigation District has constructed a small dam and gravity canal taking water from Butte Creek just below the town of Butte Falls and delivering it to lands in the vicinity of Eagle Point. The district has an approved filing of 75 second-feet, and the canal is designed to carry 90 secondfeet, the probable ultimate development. This irrigation project has some power possibilities. The McNeil Creek siphon operates under a head of 330 feet, and there are two drops in the canal, one of 60 feet and one of 300 feet, both occurring before any large portion of the canal water is diverted for irrigation. By using the two drops in the canal for power during the irrigation season and the McNeil Creek siphon for power during the rest of the year, a practically constant 2,000 horsepower could be generated with the authorized flow or 2,400 horsepower if the canal is used to its full designed carrying capacity.

The power value of the minor tributaries of the Rogue River below the mouth of Butte Creek is very low. In the agricultural portion of the basin the summer flow is absorbed by irrigation requirements, and in the lower canyon section the creeks are short and steep and carry little water during the season of low rainfall.

Although the Applegate River could furnish some power its chief contribution would be the regulation of flow at sites lower down afforded by the storage of water in the Applegate Reservoir. 
The Illinois River flows through an agricultural area and is used to some extent for irrigation. The natural flow is extremely variable, and without some regulation to equalize the flow the power value would be low. Fortunately, however, a practically uniform flow can be insured by developing the Kerby reservoir site. The river for most of its length below Kerby flows in a narrow canyon, good dam sites are abundant, and damage due to flowage would be negligible. The river slope in this section is about 24 feet to the mile, and practically all of the 1,250-foot fall can be utilized. There are no transportation facilities available, and special provisions must be made to handle the material involved in the construction of the power projects. Besides the Kerby site, three other sites were selected for development-the Fall Creek, Clear Creek, and Bald Mountain power sites. If these were operated as one system they would generate in an assumed normal year 145,000 continuous horsepower.

Although it will no doubt be possible to generate some power on many of the minor tributaries of the Rogue River, the plants will necessarily be small, supplying a local market. The municipal plant at Ashland is an example of a development making a maximum use of a small stream. The plants on Mill Creek and Reuben Creek are other examples. However, it seems impracticable to consider these small sites in a preliminary investigation of this sort unless they are already utilized or there is some condition that makes them particularly valuable.

The total potential power on the Rogue River and its tributaries amounts to 558,000 horsepower for 50 per cent of the time and 189,000 horsepower for 90 per cent of the time with the natural flow of the stream, or to 576,000 horsepower for 50 per cent of the time and 456,000 horsepower for 90 per cent of the time with the flow regulated by the four proposed reservoirs.

\section{DEVELOPED SITES}

There are eight developed water-power sites in the Rogue River Basin. The rated capacity of the turbines and water wheels installed is 59,800 horsepower. The power generated is used to pump water for irrigation, to drive sawmills, and to produce electricity for genera] uses.

\section{PROSPECT POWRR PLATT (12RD 6)}

The plant that has its power house below the small town of Prospect is the largest power plant in Oregon. (See pls. 16, B, and 17,B.) In this vicinity the river falls rapidly (see pl. 10, $A$ ), and a 50 -foot diversion dam has been built ir the SE. $1 / 4$ sec. 30, T. 32 S., R. 3 E., with a concrete-lined canal 6,840 feet long: leading to a small forebay. Two pipe lines 3,100 feet long lead from the forebay to a surge tank 150 feet high at the edge of the canyon. Two steel penstock. 850 feet long conduct the water from the tank to two Pelton water wheel which have a capacity of 23,400 horsepower each and are direct-connected to two 


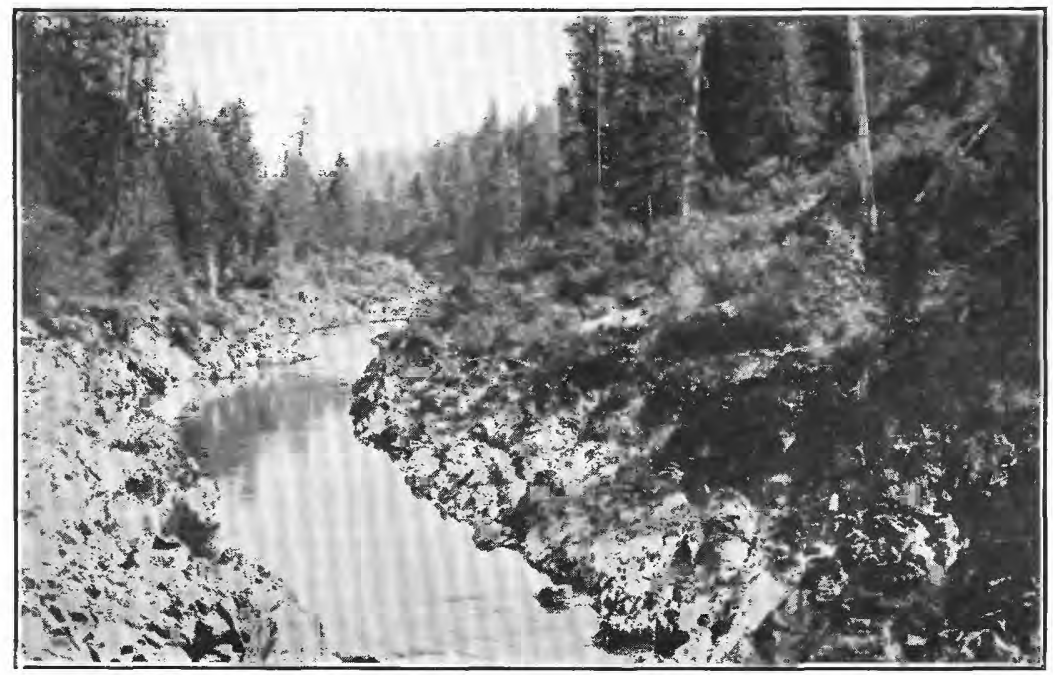

A. JOSEPHINE CREEK DAM SITE FOR KERBY RESERVOIR, ON ILLINOIS RIVER, ROGUE RIVER BASIN

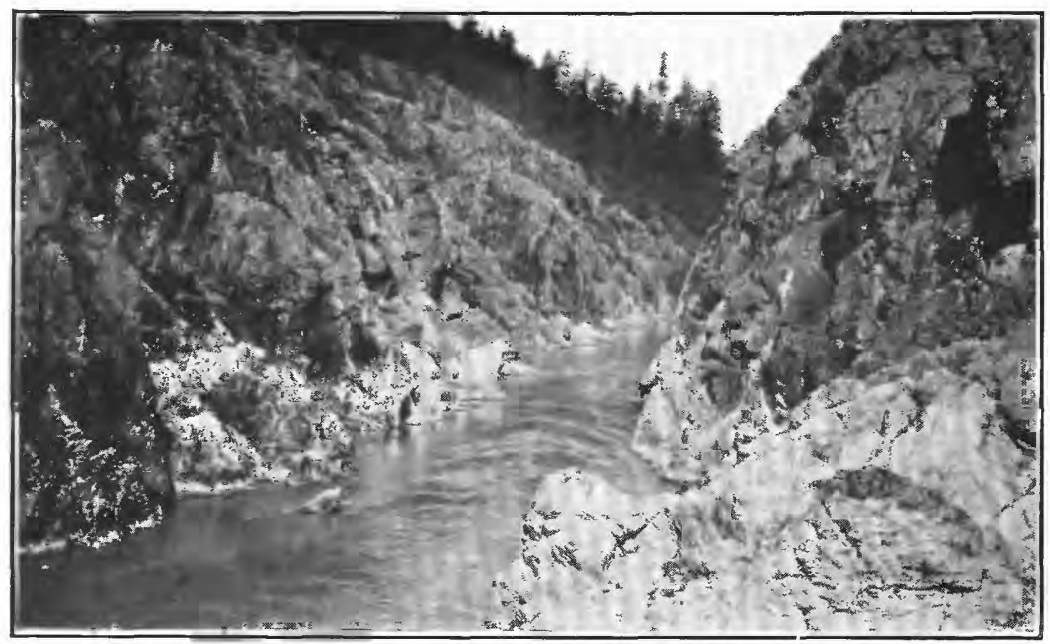

B. HELL GATE DAM SITE, ROGUE RIVER BASIN 



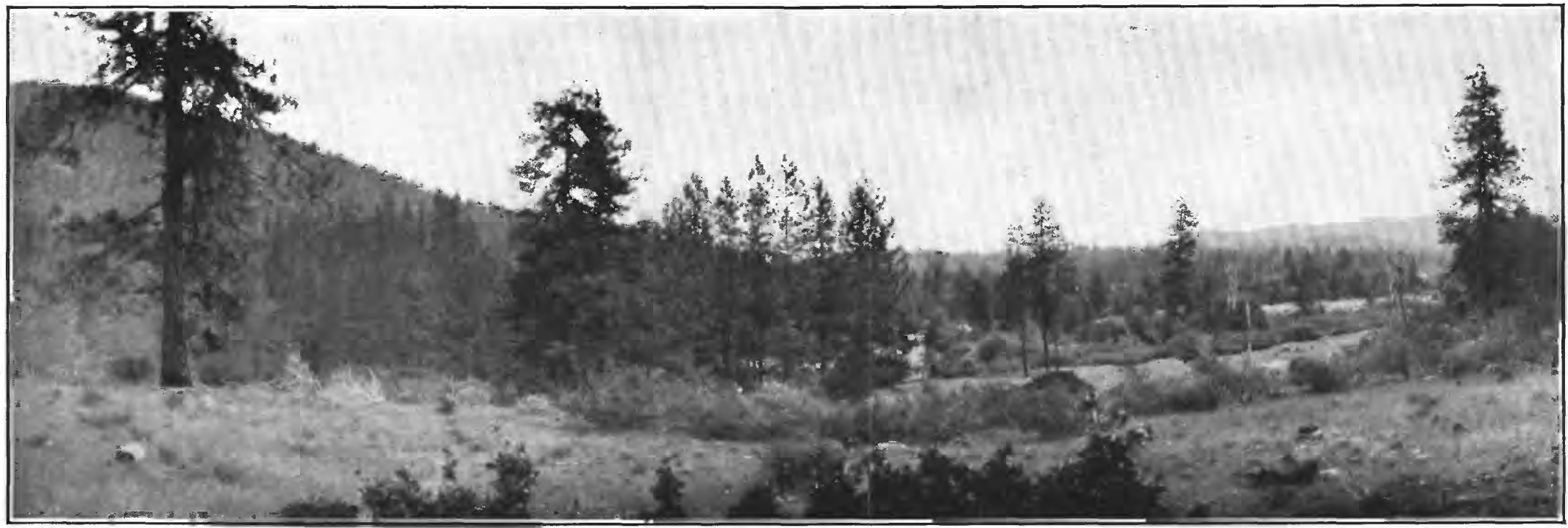

A. LOWER END OF KERBY RESERVOIR SITE ON ILLINOIS RIVER, ROGUE RIVER BASIN

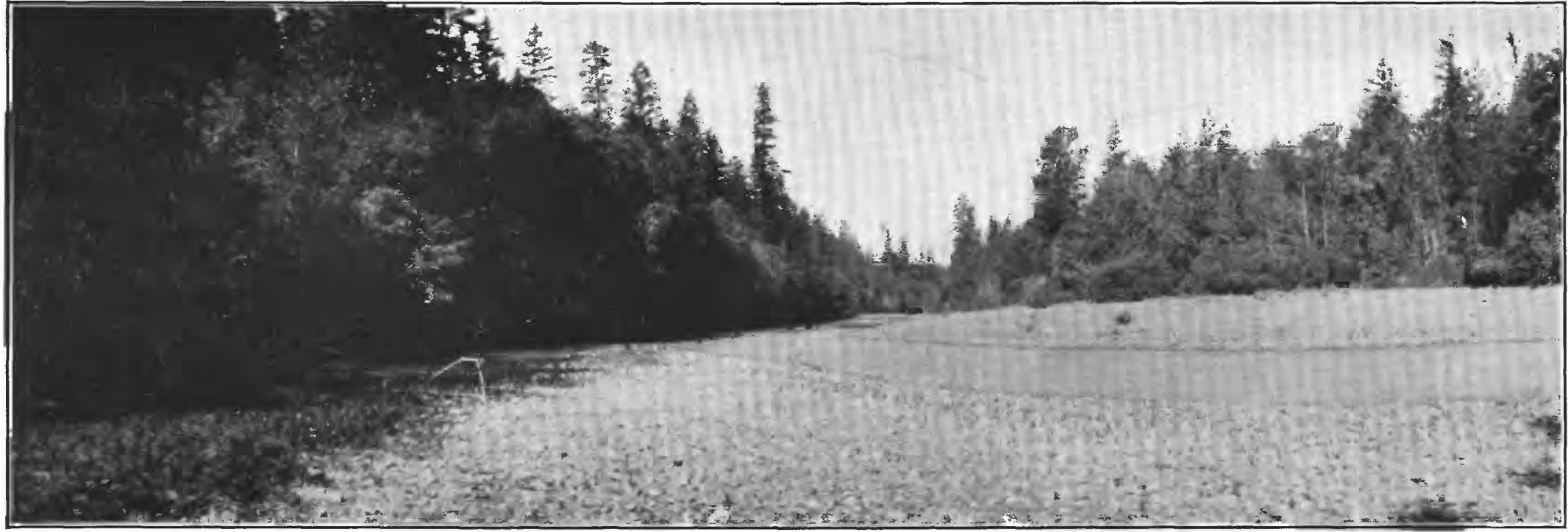

B. DAM SITE FOR RESERVOIR ON APPLEGATE RIVER, ROGUE RIVER BASIN 


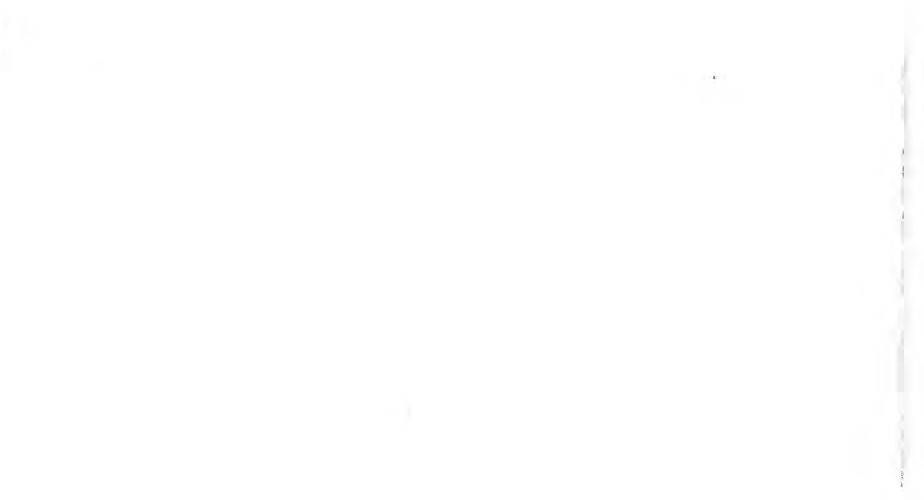




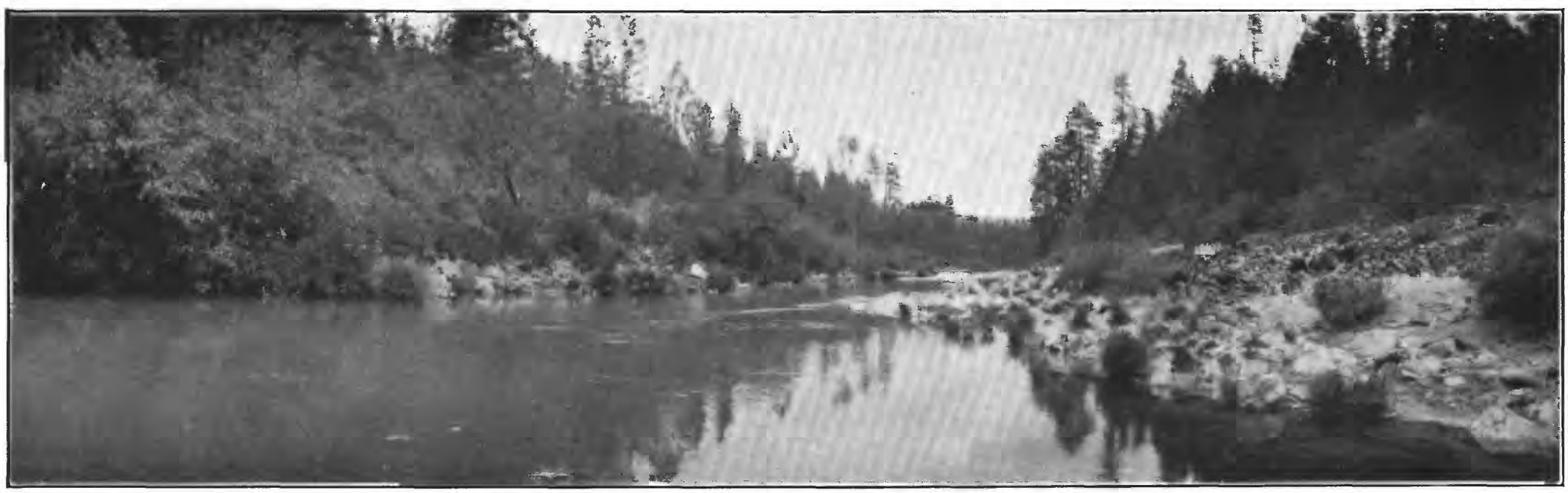

A. KERBY DAM SITE, ILLINOIS RIVER, ROGUE RIVER BASIN

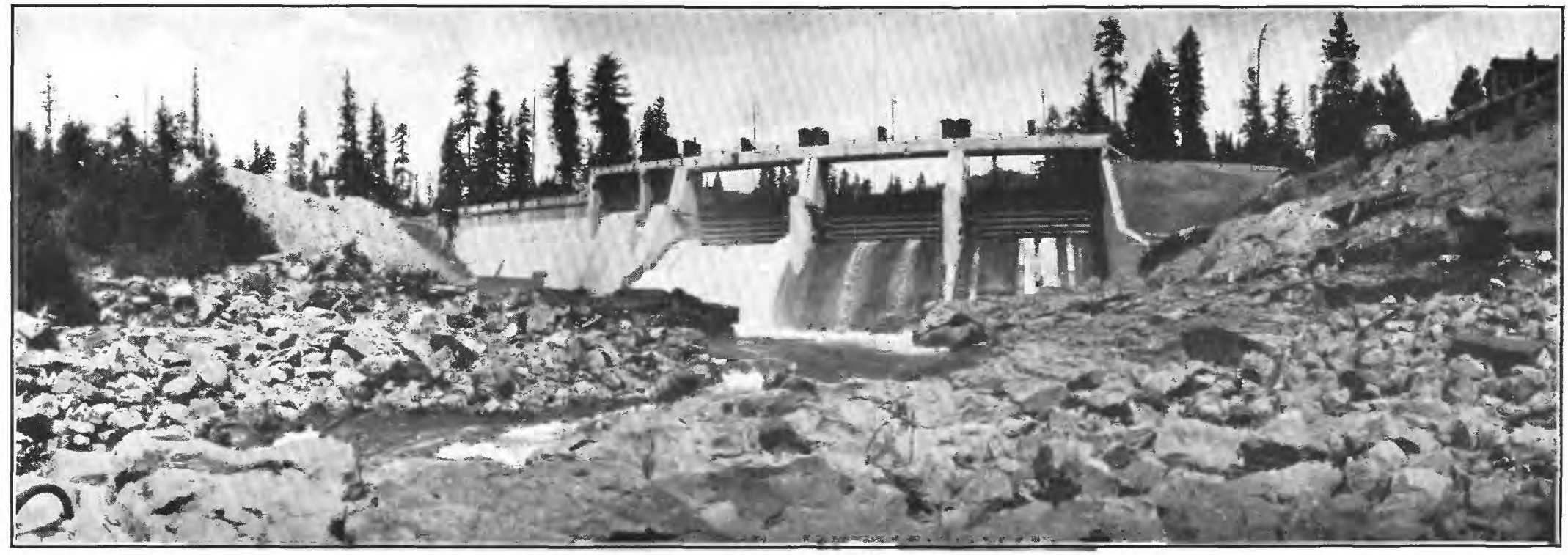

B. DIVERSION DAM OF PROSPECT POWER PLANT, ROGUE RIVER BASIN 



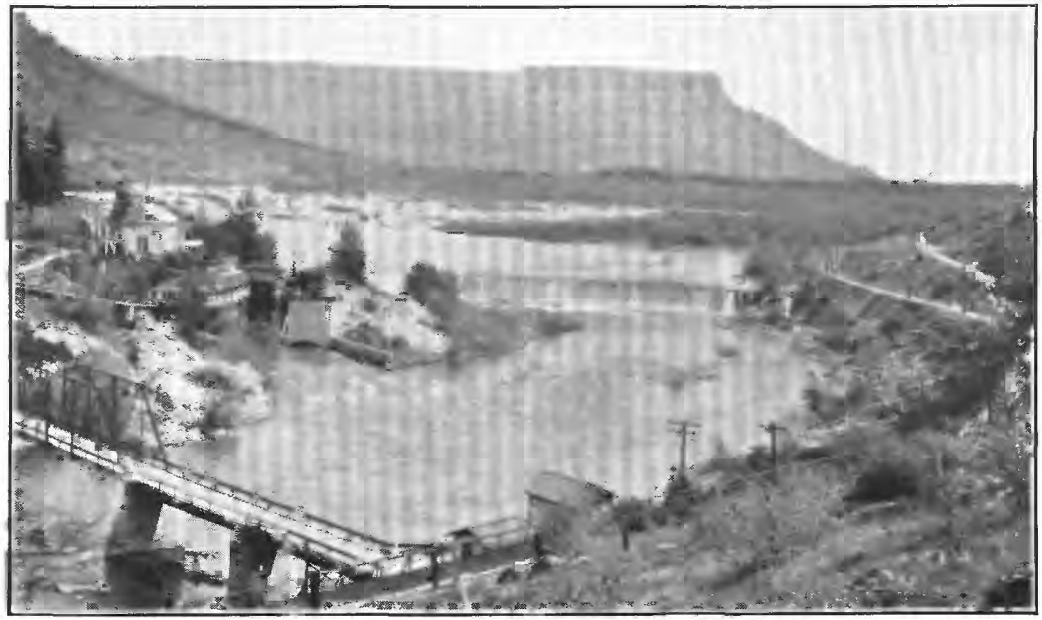

A. RAYGOLD POWER PLANT, ROGUE RIVER BASIN

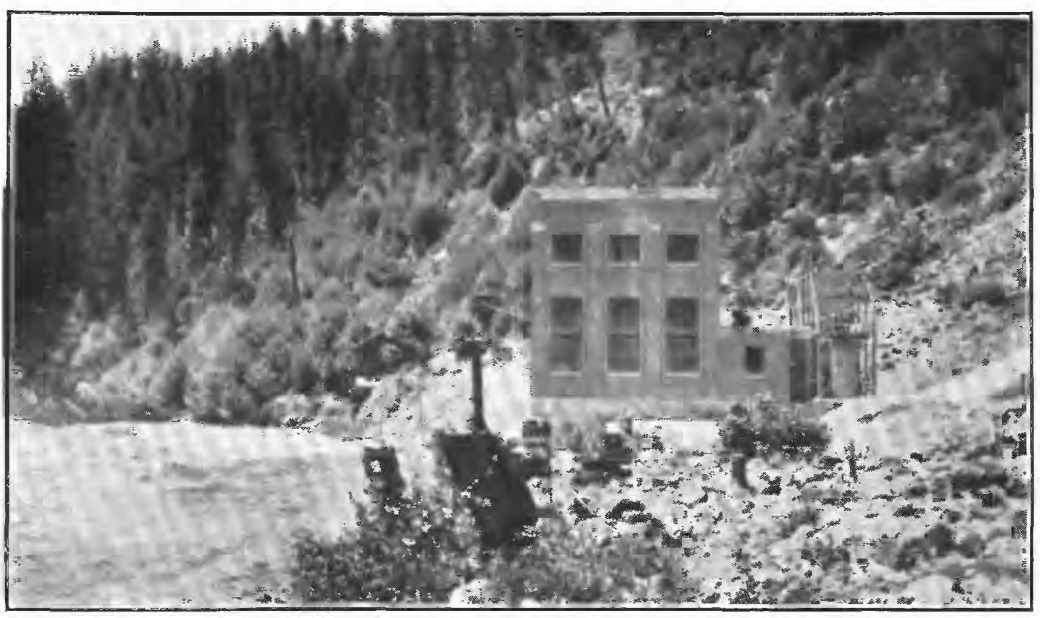

B. PROSPECT POWER hoUSE NO. 2, ROGUE RIVER BASIN 
. 
20,000 kilovolt-ampere General Electric generators. The operating head at the plant is 600 feet, and the total head is roughly estimated at 620 feet. The original power house is a short distance upstream and contains an impulse-type Francis turbine rated at 7,000 horsepower direct-connected to a generator rated at 4,590 kilovolt-amperes.

It is planned to divert the Middle and South Forks of the Rogue River, as well as Mill, Bar, and Red Blanket Creeks into the Rogue River above the diversion dam for this project, thus furnishing a large additional supply of water that could be used through the present plant.

Potential power at developed site 12RD 6

\begin{tabular}{|c|c|c|c|c|}
\hline \multirow{2}{*}{ 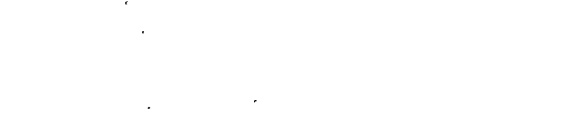 } & \multicolumn{2}{|c|}{ Flow (second-feet) } & \multicolumn{2}{|c|}{ Horsepower } \\
\hline & $\begin{array}{c}90 \text { per cent } \\
\text { of time }\end{array}$ & $\begin{array}{l}50 \text { per cent } \\
\text { of time }\end{array}$ & $\begin{array}{l}90 \text { per cent } \\
\text { of time }\end{array}$ & $\begin{array}{l}50 \text { per cent } \\
\text { of time }\end{array}$ \\
\hline 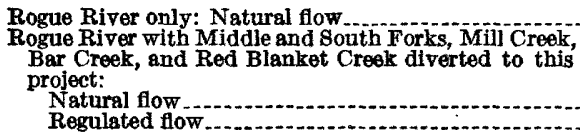 & $\begin{array}{l}700 \\
795\end{array}$ & $\begin{array}{l}1,330 \\
1,330\end{array}$ & $\begin{array}{l}34,700 \\
39,400\end{array}$ & $\begin{array}{l}66,000 \\
66,000\end{array}$ \\
\hline
\end{tabular}

By adopting the unified plan the total power output will be practically doubled. The added expense, which should not be high, will be incurred for the construction of about 7 miles of open flume or canal and 1.5 miles of tunnel.

Practically no water is diverted from the river above the dam. The country that would be crossed by the canals is heavily timbered but is unsettled, and the damage caused by construction would be low. The scenic beauty of Mill Creek Falls would be ruined ecxept during periods of high water, and the sawmill at Prospect would be deprived of its water; but no other material damage would be done to existing or proposed improvements. The flood flow could readily be passed over the small diversion dams.

\section{RAYGOLD POWER PLANT (12RD 15)}

The Raygold plant of the California-Oregon Power Co. is on the Rogue River at Raygold, in the SE. 1/4 sec. 18, T. $36 \mathrm{~S}$, R. $2 \mathrm{~W}$. The dam is a rock-filled timber-crib structure with a concrete-core wall. (See pl. 17, A.) It is about 20 feet high and 420 feet long, is slightly arched upstream, and is built on bedrock, to which it is anchored by iron drift bolts. A granite-masonry retaining wall 4 feet thick at the top and 300 feet long forms one side of the headrace, which is about 60 feet wide and 12 feet deep. Flood waters are taken care of by natural overflow on the entire length of the dam and by gates near the lower end of the forebay. The head available at the power house is slightly over 20 feet. The hydraulic machinery consists of two S. Morgan Smith 42-inch twin turbines, rated at 1,000 horsepower each, and two smaller wheels rated at 375 horsepower each, or a total of 2,750 horsepower. This power drives two 750-kilovolt-ampere generators and one 450-kilovolt-ampere generator, or a total of 1,950 kilovoltamperes. The electricity produced is fed directly into the transmission system of the California-Oregon Power Co. 
Potential power at developed site 12RD 15

\begin{tabular}{|c|c|c|c|c|}
\hline \multirow[t]{2}{*}{ - } & \multicolumn{2}{|c|}{ Flow (second-feet) } & \multicolumn{2}{|c|}{ Horsepower } \\
\hline & $\begin{array}{l}90 \text { per cent } \\
\text { of time }\end{array}$ & $\begin{array}{l}50 \text { per cent } \\
\text { of time }\end{array}$ & $\begin{array}{l}90 \text { per cent } \\
\text { of time }\end{array}$ & $\begin{array}{l}50 \text { per cent } \\
\text { of time }\end{array}$ \\
\hline $\begin{array}{l}\text { Natural flow } \\
\text { Regulated flow }\end{array}$ & $\begin{array}{l}1,110 \\
1,670\end{array}$ & $\begin{array}{l}2,150 \\
2,150\end{array}$ & $\begin{array}{l}1,950 \\
2,940\end{array}$ & $\begin{array}{l}3,780 \\
3,780\end{array}$ \\
\hline
\end{tabular}

The maximum flood that may be expected in a long period of years is about 87,000 second-feet; of this amount about 4,000 second-feet can be used by the wheels and possibly another 4,000 second-feet can be passed through the gates in the headrace. The remainder, or 79,000 second-feet, must be passed over the spillway, which is 420 feet long. Raising the pond level between 14 and 15 feet will permit the passage of this water.

\section{GOLD HIIL POWER PLANT (12RD 16s)}

The power plant on the Rogue River a short distance above the town of Gold Hill, at the time it was examined in 1923, was being used to pump water for that town. The natural fall of the river is taken advantage of by a small wing dam which diverts the water in the NW. 1/4 sec. 15, T. $36 \mathrm{~S}$., R. 3 W., and by a canal about half a mile long which carries the water to a power house in the $S W .1 / 4$ sec. 15. The plant was greatly underdeveloped and in a poor state of repair. The head available is about 18 feet, but probably not over 20 horsepower was being produced by the water wheel, which is belt-connected to a small triplex pump. By an enlargement of the present headrace and suitable alterations of the power house and the hydraulic equipment, this development could be made valuable. (See description of the undeveloped power site at Gold Hill (12RD 16), p. 82.)

Potential power at developed site 12RD 16a

\begin{tabular}{|c|c|c|c|c|}
\hline & \multicolumn{2}{|c|}{ Flow (second-feet) } & \multicolumn{2}{|c|}{ Horsepower } \\
\hline & $\begin{array}{c}90 \text { per cent } \\
\text { of time }\end{array}$ & $\begin{array}{c}50 \text { per cent } \\
\text { of time }\end{array}$ & $\begin{array}{c}90 \text { per cent } \\
\text { of time }\end{array}$ & $\begin{array}{l}50 \text { per cent } \\
\text { of time }\end{array}$ \\
\hline $\begin{array}{l}\text { Natural flow } \\
\text { Regulated flow }\end{array}$ & $\begin{array}{l}1,110 \\
1,670\end{array}$ & 2,190 & $\mathbf{2}, \mathbf{6 0 0}$ & $\begin{array}{l}3,150 \\
3,150\end{array}$ \\
\hline
\end{tabular}

SAVAGE RAPIDS POWER PLANT (12RD 18)

The plant of the Grants Pass Irrigation District is at Savage Rapids, on the Rogue River, in the SE. $1 / 4$ sec. 24, T. 36 S., R. 5 W., and the SE. $1 / 4$ sec. 19 , T. 36 S., R. 4 W. A combination multiple-arch and solid-concrete dam is constructed partly on native rock and partly on cemented gravel. (See pl. 19, A.) Sixteen hydraulically operated radial-type gates, each capable of passing 3,000 second-feet, are provided to carry the floods. The head developed is 28 feet. Two 48-inch horizontal Allis-Chalmers turbines, each rated at 900 horsepower, are direct-connected to centrifugal pumps that deliver water to ditches 150 feet above the river on the north side and 90 feet above it on the south side. In addition to these lifts the irrigation system includes a gravity canal with a carrying capacity of about 150 second-feet. All the power produced is used for irrigation. 
Potential power at developed site 12RD 18

\begin{tabular}{|c|c|c|c|c|}
\hline & \multicolumn{2}{|c|}{ Flow (second-feet) } & \multicolumn{2}{|c|}{ Horsepower } \\
\hline & $\begin{array}{l}90 \text { per cent } \\
\text { of time }\end{array}$ & $\begin{array}{l}50 \text { per cent } \\
\text { of time }\end{array}$ & $\begin{array}{c}90 \text { per cent } \\
\text { of time }\end{array}$ & $\begin{array}{l}50 \text { per cent } \\
\text { of time }\end{array}$ \\
\hline $\begin{array}{l}\text { Natural flow } \\
\text { Regulated flow... }\end{array}$ & $\begin{array}{r}930 \\
1,490\end{array}$ & $\begin{array}{l}2,340 \\
2,340\end{array}$ & $\begin{array}{l}2,080 \\
3,340\end{array}$ & $\begin{array}{l}5,240 \\
5,240\end{array}$ \\
\hline
\end{tabular}

The maximum flood that may be expected in a long period of years is about 100,000 second-feet. The dam is designed to pass 48,000 second-feet without raising the pond level. With a maximum flood, however, the pond would rise about 5 feet even with all the gates open.

\section{MIIL CREFK POWER PLANT (12RD 26)}

The Mill Creek power plant, at Prospect, has been used for sawing lumber. A short flume diverts water from Mill Creek and delivers it to the water wheel at the mill under a head of about 25 feet. Less than 30 horsepower was being used. The flume is in poor shape, and the whole outfit is of a temporary nature.

The natural Q90 flow at this site is 45 second-feet and the Q50 flow 85 secondfeet; 90 horsepower could be developed for 90 per cent of the time and 170 horsepower for 50 per cent of the time.

\section{BUTTE FAIIS POWER PLANT (12RD 29)}

The Butte Falls Lumber Co. has a plant on Butte Creek at Butte Falls. By using a small timber-crib dam and a wood flume about 500 feet long a head of 49 feet is made available. The hydraulic equipment consists of a Leffel wheel rated at 500 horsepower and a McCormick wheel rated at 250 horsepower. The power has not been used for several years, and the plant is partly dismantled, but formerly it was used for running a sawmill.

The natural Q90 flow at this site is 133 second-feet and the Q50 flow 160 second-feet; 520 horsepower could be developed for 90 per cent of the time and 626 horsepower for 50 per cent of the time.

\section{ASHLAND POWER PLANT (12RD 31)}

The Ashland municipal plant diverts water from the East and West Forks of Ashland Creek and carries it to the power house in the NW. $1 / 4$ sec. 21, T. $39 \mathrm{~S}$., R. 1 E. (See pl. 18, A.) The effective head is 420 feet. A new dam was constructed in 1928. The equipment consists of a 56-inch impulse turbine making 300 revolutions a minute, rated at 600 horsepower, direct-connected to a 300 kilowatt 4,000-volt 43-ampere 3-phase 60-cycle generator, which in turn is excited by a 12/1/2-kilowatt generator belt connected to the water-wheel shaft. Appropriate governing and switching apparatus is also included.

\section{REUBEN CREEK POWER PLANT (12RD 33)}

A mining company has been granted a license by the Federal Power Commission for a project on Reuben Creek, a tributary of Graves Creek. A diversion dam of logs and rock has been built in the SE. $1 / 4$ NE. 1/4 sec. 24, T. 33 S., T. 8 W. From the dam a conduit $1 \frac{112}{2}$ miles long leads to a power house in the NW. $1 / 4 \mathrm{SW} .1 / 4 \mathrm{sec}$. 30, T. 33 S., R. 7 W. The site has a potential capacity of 62 horsepower for about 50 per cent of the time and 27 horsepower for 90 per cent of the time. Power is used for mining and lighting. In 1913 a 4-inch Pelton wheel was in use at the site. It was operated under a 90 -foot head and supplied about 16 horsepower to a sawmill. This was a temporary plant. 


\section{UNDEVELOPED SITES}

The following study of the undeveloped water power of the Rogue River is based on maps prepared by the topographic branch of the Geological Survey, on a field investigation of each of the proposed sites, and on office studies of such material as is in the files. The sites are described in order, starting with the highest part of the basin and working downstream on the Rogue River, then on its tributaries, in the same order. (See pl. 3.)

\section{HAMAKER POWER STTE (12RD 1)}

The Hamaker Reservoir and power site is in secs. 20 and 21, T. 29 S., R. 4 E. (See fig. 8 and pl. 11, B.) A dam 160 feet high would flood to the 3,900-foot contour and provide a storage capacity of 21,000 acre-feet, which could be used for partial regulation of the flow above Prospect. The storage possibilities have been considered on pages 58-60. The volume in the lower 40 feet of the reservoir is small. This portion, therefore, may be used to maintain a power head. By tapping the reservoir at the 40 -foot level, or at an altitude of 3,780 feet, and carrying the water in a conduit $1 \frac{1}{2}$ miles long on the left bank of the river, then turning it into a penstock a quarter of a mile long, the water will be returned to the river at an altitude of 3,580 feet, making available a total head of 200 feet.

The dam site is at a narrows where the river leaves its flood plain and tumbles over rock that crops out in the bed of the stream and to a height of nearly 20 feet on both banks. The geologic structure along the line of the proposed dam is shown in the cross section on Figure 8.

The rock exposed in the banks at the site is a basaltic lava, about 20 feet thick, containing distinct crystals of olivine. This flow has a vesicular crust and a dense middle portion and base. On the east wall it is overlain by a pumice mud flow to the top of the canyon, and hence well above the proposed height of the dam. Lack of time prevented a thorough examination of the brush-covered west wall, but it is believed that this is the ancient rock wall with only a thin cover of ash. Below the olivine basalt lies another lava flow of reddish hue, containing prominent feldspar crystals. This lava was not examined under the microscope, but it resembles an andesite in its habit, for it shows platy structure. It crops out downstream from the site for several hundred feet. The contact of the olivine basalt with this andesite is not exposed. Probably the river has cut through the basalt (see line T-S, fig. 8) and is flowing on the andesite, but it was not feasible to obtain a specimen from the river bed to determine this fact. No trouble should be met in anchoring the proposed dam, as this rock will provide a suitable foundation.

The unfavorable feature of this site is the presence of the mud flow on the east side, which would form an unsatisfactory abutment. Further, there are possibilities of leakage that might be difficult to overcome. Because the mud flow is the eritical feature of the dam site a traverse was made of it to the point where National Creek crosses the Diamond Lake road. The pumice-covered bench, or mud flow, was found to extend all the way to National Creek, a distance of nearly 2 miles in a southerly direction. National Creek, at its confluence with the Rogue River, has an altitude of 3,575 feet, or $\mathbf{1 6 4}$ feet lower than the water surface of the Rogue at the Hamaker dam site. Thus water escaping through the east abutment would have a steep hydraulic gradient, and a line of springs would probably result along the east bank of the Rogue between the dam site and National Creek. . The amount of water that would escape in this manner is unknown, but it might be sufficient to cause the failure of the reservoir.

The mud flow is estimated to exceed half a mile in width on the east bank of the Rogue at the dam site, hence it appears impracticable to lay a cut-off wall 
to prevent leakage. The details of the west bank are unknown but should be investigated for a possibility of leakage into Foster Creek, which lies southwest of the dam site. It is recommended that a line of holes be drilled along the line of the dam site to determine the contour of the buried rock floor and the character of the contact of the lava flows underlying the pumice. If the width and thickness of the mud flow at this place are not so great as has been estimated, a cutoff wall to prevent leakage might be feasible. The drill holes should be pressure tested to determine the permeability of the pumiceous flow. Also it would be worth while to determine whether the ancient rock walls of the buried valley are closer together at any place downstream.

This site is believed to be a practicable one in the major program of power development on the river. There is a possibility that a lower dam would regulate the flow of the Rogue as well as one 160 feet high because of the underground storage in the thick pumice beds in the reservoir site; under such conditions the leakage would probably not exceed the amount of water that would have to be released for use downstream. Thus this site would be satisfactory as a power reservoir, though it might be a failure for the storage of irrigation water.

Potential power at undeveloped site 12RD 1

\begin{tabular}{|c|c|c|c|c|}
\hline \multirow[b]{2}{*}{. } & \multicolumn{2}{|c|}{ Flow (second-feet) } & \multicolumn{2}{|c|}{ Horsepower } \\
\hline & $\begin{array}{l}90 \text { per cent } \\
\text { of time }\end{array}$ & $\begin{array}{c}50 \text { per cent } \\
\text { of time }\end{array}$ & $\begin{array}{l}90 \text { por cent } \\
\text { of time. }\end{array}$ & $\begin{array}{l}50 \text { per cent } \\
\text { of time }\end{array}$ \\
\hline $\begin{array}{l}\text { Natural flow } \\
\text { Reguilated flow }\end{array}$ & $\begin{array}{r}80 \\
130\end{array}$ & $\begin{array}{l}125 \\
130\end{array}$ & $\begin{array}{l}1,280 \\
2,080\end{array}$ & $\begin{array}{l}2,000 \\
2 ; 080\end{array}$ \\
\hline
\end{tabular}

Between National Creek and Castle Creek the average fall is $\mathbf{1 4}$ feet to the mile, and with storage the potential power is $\mathbf{1 4 5}$ horsepower to the mile.

\section{CASTLE CREKK POWER SITE (12RD 2)}

By constructing a 40-foot dam just below the mouth of Castle Creek in sec. 26, T. 30 S., R. 3 E., and carrying the water in an open flume on the right bank along the 3,480-foot contour for a distance of 1.6 miles, then turning it into a 700-foot penstock, a head of 200 feet could be used. At the 40 -foot height the dam would be 350 feet long, and no difficulty should be experienced in constructing or sealing such a dam. There are no diversions above this project, and practically no damage would be done by flooding above the dam or by the construction of the flume and hydraulic structures.

Potential power at undeveloped site 12RD 2

\begin{tabular}{|c|c|c|c|c|}
\hline \multirow[b]{2}{*}{$i$} & \multicolumn{2}{|c|}{ Flow (second-feet) } & \multicolumn{2}{|c|}{ Horsepower } \\
\hline & $\begin{array}{c}90 \text { per cent } \\
\text { of time }\end{array}$ & $\begin{array}{c}50 \text { per cent } \\
\text { of time }\end{array}$ & $\begin{array}{l}90 \text { per cent } \\
\text { of time }\end{array}$ & $\begin{array}{l}50 \text { per cent } \\
\text { of time }\end{array}$ \\
\hline $\begin{array}{l}\text { Nìtural flow } \\
\text { Regulated flow.................. }\end{array}$ & $\begin{array}{l}225 \\
\mathbf{3 7 0}\end{array}$ & $\begin{array}{l}375 \\
375\end{array}$ & $\begin{array}{l}3,600 \\
4,320\end{array}$ & $\begin{array}{l}6,000 \\
6,000\end{array}$ \\
\hline
\end{tabular}

The extreme flood that may be expected will amount to about 6,000 secondfeet, which can be passed through and around the dam without difficulty: 


\section{UNION CREEK POWRR SITE (12RD s)}

The site for the diversion dam of the Union Creek project is about a.quarter of a mile below the power-house site of the Castle Creek project, near the southwest corner of sec. 35, T. 30 S., R. $3 \mathrm{E}$. This dam should probably be a very low concrete structure, which under normal conditions will divert most of the flow into the canal but will readily pass the floods over its crest. Union Creek, which enters the Rogue River a short distance below this dam site, has a remarkably wellsustained flow, and it is desirable that this stream be incorporated in the project. This may be accomplished by intercepting the creek by a canal. Waste gates should be placed in the creek channel so that all water in excess of the carrying capacity of the canal may be returned to the river.

Below Union Creek two alternate plans of development are suggested. One contemplates carrying the water across the river from a point in the $\mathrm{NW} .1 / 4$ sec. 3 to the NE. $1 / 4$ sec. 4 , T. 31 S., R. 3 E., then in an open canal along the 3,280 -foot contour to a point near the south line of section 8 , from which a pressure pipe could carry the water to the power house in the NE. $1 / 4$ sec. 17.

The second plan involves carrying the water in a canal along the left bank of the river to the SW. 1/4 sec. 3 and thence through a pressure pipe to a power house on the same side of the river.

The first plan would require the construction of 4.7 miles of open canal and 0.5 mile of penstock; the second would require 1.8 miles of canal and 2.3 miles of penstock. Owing to the difficulty of constructing and maintaining a canal on the steep hillside, as required in the first plan, it is probable that in spite of its greater length of pressure pipe the second plan would be a more economical development. The bench on which the pipe would be constructed slopes rather gently toward the southwest to a point direetly above the power house, where it drops sharply.

Potential power at undeveloped site 12RD 8 .

\begin{tabular}{|c|c|c|c|c|}
\hline & \multicolumn{2}{|c|}{ Flow (second-feet) } & \multicolumn{2}{|c|}{ Horsepower } \\
\hline & $\begin{array}{c}90 \text { per cent } \\
\text { of time }\end{array}$ & $\begin{array}{l}50 \text { per cent } \\
\text { of time }\end{array}$ & $\begin{array}{l}90 \text { per cent } \\
\text { of time }\end{array}$ & $\begin{array}{l}50 \text { per cent } \\
\text { of time }\end{array}$ \\
\hline $\begin{array}{l}\text { Natural flow } \\
\text { Regulated flow..... }\end{array}$ & $\begin{array}{l}290 \\
344\end{array}$ & $\begin{array}{l}500 \\
500\end{array}$ & $\begin{array}{l}6,500 \\
7,700\end{array}$ & $\begin{array}{l}11,200 \\
11,200\end{array}$ \\
\hline
\end{tabular}

A flood flow of about 8,000 second-feet can be passed over the dam and through the waste gates. No damage to existing improvements would be involved in this development.

\section{TOP CREEK POWER SITE (12RD 4)}

By constructing a 20 -foot dam in the SE. $1 / 4$ sec. 19 , T. 31 S., R. 3 E., to flood to the 2,960-foot contour, carrying the water in a canal 1.2 miles long, and turning it into a penstock 0.7 mile long leading to a power house in the NW. $1 / 4$ sec. 32 , a head of 140 feet would be created at the Top Creek power site.

Potential power at undeveloped site $12 R D_{4}$

\begin{tabular}{|c|c|c|c|c|}
\hline \multirow{2}{*}{. } & \multicolumn{2}{|c|}{ Flow (second-feet) } & \multicolumn{2}{|c|}{ Horsepower } \\
\hline & $\begin{array}{l}90 \text { per cent } \\
\text { of time }\end{array}$ & $\begin{array}{l}50 \text { per cent } \\
\text { of time }\end{array}$ & $\begin{array}{l}90 \text { per cent } \\
\text { of time }\end{array}$ & $\begin{array}{l}50 \text { per cent } \\
\text { of time }\end{array}$ \\
\hline $\begin{array}{l}\text { Natural flow } \\
\text { Regulated flow }\end{array}$ & $\begin{array}{l}325 \\
385\end{array}$ & $\begin{array}{l}\mathbf{5 7 5} \\
\mathbf{5 7 5}\end{array}$ & $\begin{array}{l}3,640 \\
4,310\end{array}$ & $\begin{array}{l}6,440 \\
6,440\end{array}$ \\
\hline
\end{tabular}


The eonditions are favorable for the construction of a 20-foot dam of an overflow section. It would have a crest length of about 250 feet and could readily pass the flood flow, which might reach 10,000 second-feet. There are no diversions above this site, and no damage to existing improvements would be caused by the construction of the dam.

\section{RITER CREER POWER SITE (12RD 5)}

The dam site for the Riter Creek project is near the north line of sec. 8, T. $32 \mathrm{~S}$., R. 3 E. The right bank is steep, and it appears that a canal could be carried along it on grade only with difficulty. The left bank is rather flat and slopes toward the south and is therefore much better suited to easy canal construction. A more detailed study might show that a penstock constructed across the sloping bench on the left bank of the river and connecting the lower power house with the gravity ditch would be more economical than a conduit on grade on the right bank. By constructing a 15-foot overflow-section dam the water will be raised to the 2,800-foot level, and by carrying it by combined canal and pipe line a distance of about 3.5 miles to a power house in the SW. $1 / 4$ sec. 20, T. 32 S., R. 3 E., a head of 200 feet will be created.

Potential power at undeveloped site 12RD 5

\begin{tabular}{l|r|r|r|r}
\hline & Flow (second-feet) & \multicolumn{2}{|c|}{ Horsepower } \\
\cline { 2 - 4 } & $\begin{array}{r}90 \text { per cent } \\
\text { of time }\end{array}$ & $\begin{array}{r}50 \text { per cent } \\
\text { of time }\end{array}$ & $\begin{array}{r}90 \text { per cent } \\
\text { of time }\end{array}$ & $\begin{array}{r}50 \text { per cent } \\
\text { of time }\end{array}$ \\
\hline Natural flow. & 330 & 585 & 5,280 & 9,360 \\
6,180 & 5,360 \\
\hline
\end{tabular}

As the crest length of the dam is over 200 feet the maximum flood which may be expected can easily be passed. No appreciable damage would be caused by this development.

\section{PROSPECT POWRR SITE (12RD 6)}

The development of additional power at the Prospect site has been considered in connection with the description of the plant now in operation. (See pp. 68-69.)

\section{CASCADE POWER SITK (12RD 7)}

Water for the Cascade power project would be diverted in the NW. 1/4 sec. 6 , T. 33 S., R. 3 E., just below the Prospect power house, and carried by conduit along the right bank to a point in the $\mathrm{NW} 1 / 4$ sec. 15 , T. $33 \mathrm{~S}$., R. 2 E., where a head of 230 feet would be obtained. The river in this section flows in a canyon with steep wooded banks, and the conduit would probably be a pipe line. The discharge for this plant would be slightly greater than for the Prospect plant, because of seepage water entering the gorge below the Prospect Dam. This increase is roughly estimated at 70 second-feet for 90 per cent of the time and 100 second-feet for 50 per cent of the time. No damage would be caused by "the construction of this plant, as the land affected is valueless for any other purpose. The Crater Lake Highway runs along the edge of the canyon and would facilitate construction.

In estimating the potential power of this site it has been assumed that the flow of Mill and Red Blanket Creeks and the Middle and South Forks of the Rogue River will be diverted to the Rogue River above the intake of the Prospect plant. 
Potential power at undeveloped site 12RD 7

[Head, 230 feet]

\begin{tabular}{|c|c|c|c|c|}
\hline & \multicolumn{2}{|c|}{ Flow (second-feet) } & \multicolumn{2}{|c|}{ Horsepower } \\
\hline & $\begin{array}{l}90 \text { per cent } \\
\text { of time }\end{array}$ & $\begin{array}{c}50 \text { per cent } \\
\text { of time }\end{array}$ & $\begin{array}{l}90 \text { per cent } \\
\text { of time }\end{array}$ & $\begin{array}{l}50 \text { per cent } \\
\text { of time }\end{array}$ \\
\hline 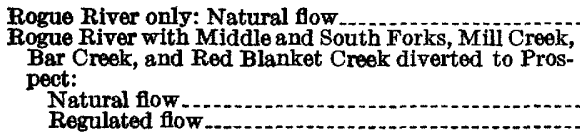 & $\begin{array}{l}775 \\
870\end{array}$ & $\begin{array}{l}1,430 \\
1,430\end{array}$ & $\begin{array}{l}11,500 \\
14,200 \\
16,000\end{array}$ & $\begin{array}{l}16,600 \\
26,300 \\
26,300\end{array}$ \\
\hline
\end{tabular}

IOST CREEK POWER SITE (12RD 8)

The dam site for the Lost Creek reservoir and power project is in sec. 26, T. 33 S., R. 1 E. The principal features of the reservoir site have been described on pages 60-62. (See fig. 9 and pl. 13, A.)

The west abutment of the dam site is massive basalt similar in appearance to Columbia River basalt. It is irregularly jointed and nearly impermeable. The same massive dark fine-grained basalt is exposed also in the river bed and for about 100 feet up the west wall of the canyon. Above this point there crops out an olivine basalt which is fresher and more recent than the basalt below it. The contact of the two rocks is not visible because of vegetation. No difficulty will be experienced in obtaining an excellent foundation for the proposed dam. About 200 feet upstream from the left abutment there are outcrops of a soft thin-bedded volcanic agglomerate dipping upstream. This rock was not found in the west abutment, but the absence of outcrops might possibly be due to the cover of vegetation. If it does occur there it is probably thin and of little consequence in the construction of a dam at this site, but it should be looked for in the test holes.

The olivine basalt in the east abutment would not affect the construction of a dam at this site, but it would affect the success of the reservoir. This olivine basalt represents the outcrop of the intracanyon lava. It was traced eastward for about half a mile where it forms the broad bench described on page 43 . The width of the bench and its thickening eastward indicate that the river has cut down on the west side of the intracanyon flow, leaving its ancient buried channel from an eighth to a quarter of a mile to the east of its present channel. This condition is shown in the cross section of the valley on Figure 9. As the ancient channel apparently was not cut as deep as the present one, the ancient channel does not now cause any seepage losses from the river. Considerable time would be necessary to map the exact location of this buried channel, because the area is thickly wooded. The facts now available indicate that the upstream end of it is in the SE. $1 / 4$ sec. 24 , T. 33 S., R. 1 E., and the downstream end is on the east bank about $1 \frac{1}{2}$ miles downstream from the dam site. The upstream or intake end is buried by the pumiceous mud flow, which is known to be permeable and which would not prevent seepage into and through the buried channel.

The amount of seepage is difficult to estimate under the known conditions. Experience elsewhere has shown that both the basalt and the gravel occupying such buried channels will carry large amounts of water. Lava tubes and slaggy, open contacts between the intracanyon flows and between these flows and the ancient canyon walls are common under such conditions and are not easily located on the surface or by means of the drill. In Plate $9, A$, is shown a lava tube in this intracanyon basalt of Rogue Valley at the natural bridge, about 20 miles 


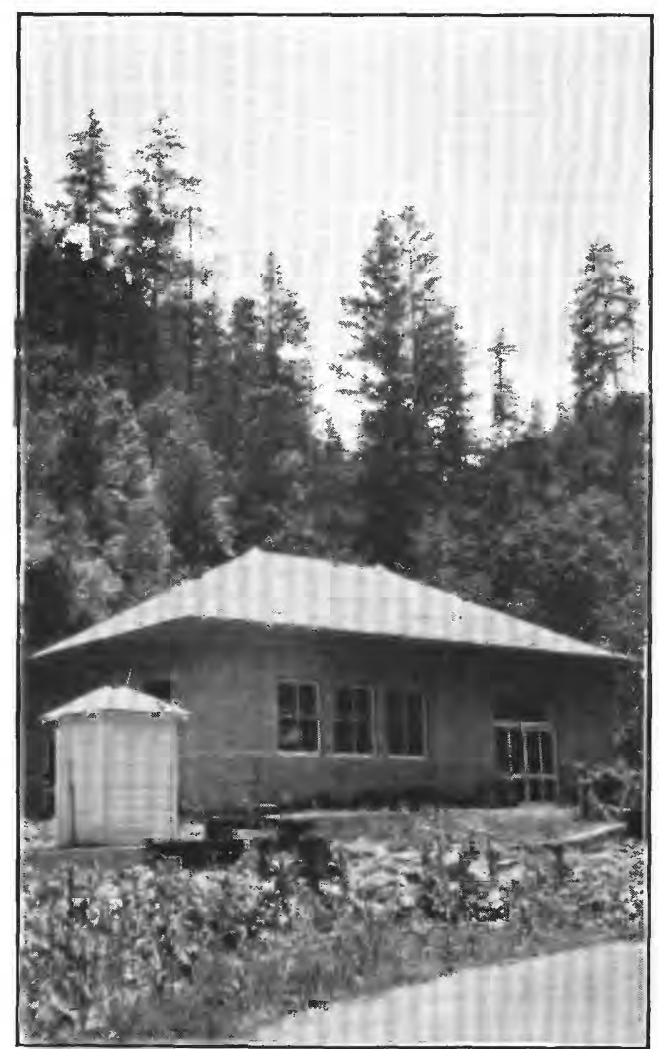

A. ASHLAND POWER HOUSE, ROGUE RIVER BASIN

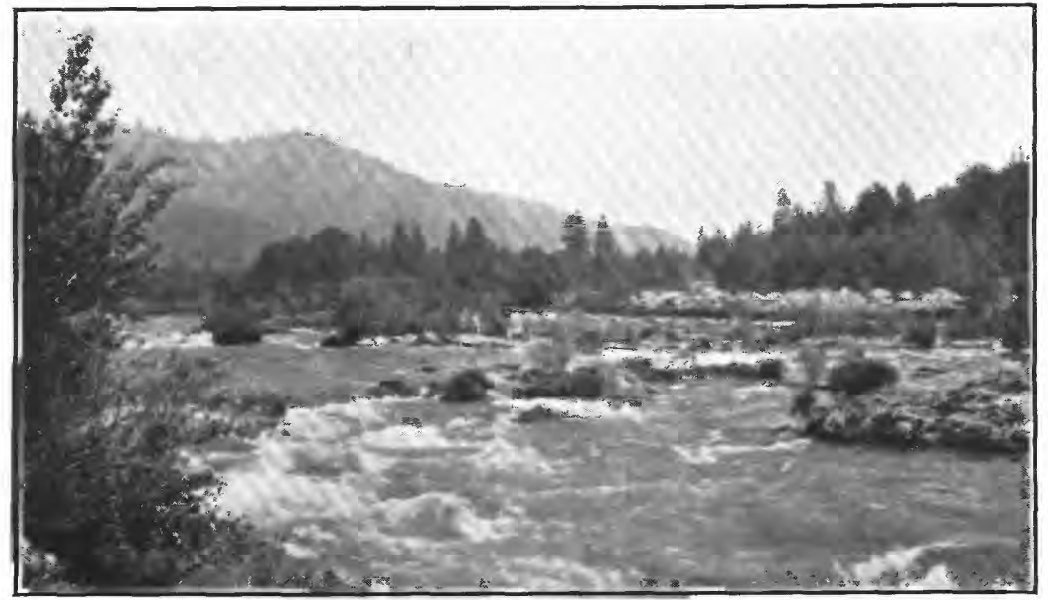

B. RAPIDS ON ROGUE RIVER ABOVE GOLD HILL 



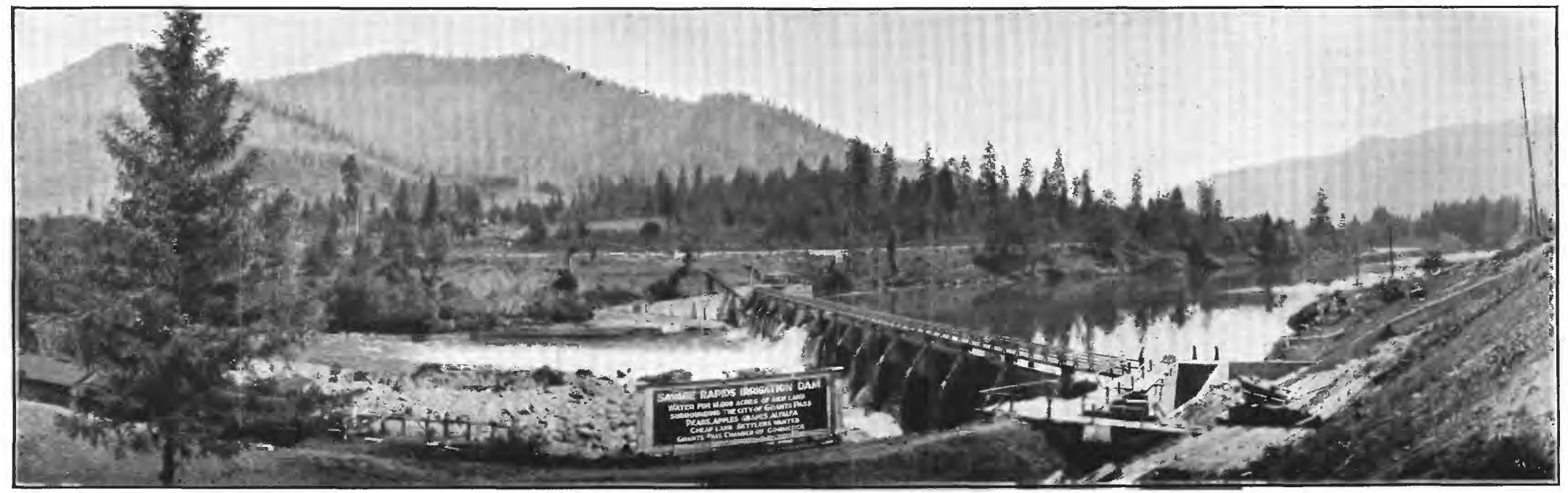

A. DAM AND PUMPING PLANT OF GRANTS PASS IRRIGATION DISTRICT AT SAVAGE RAPIDS, ROGUE RIVER

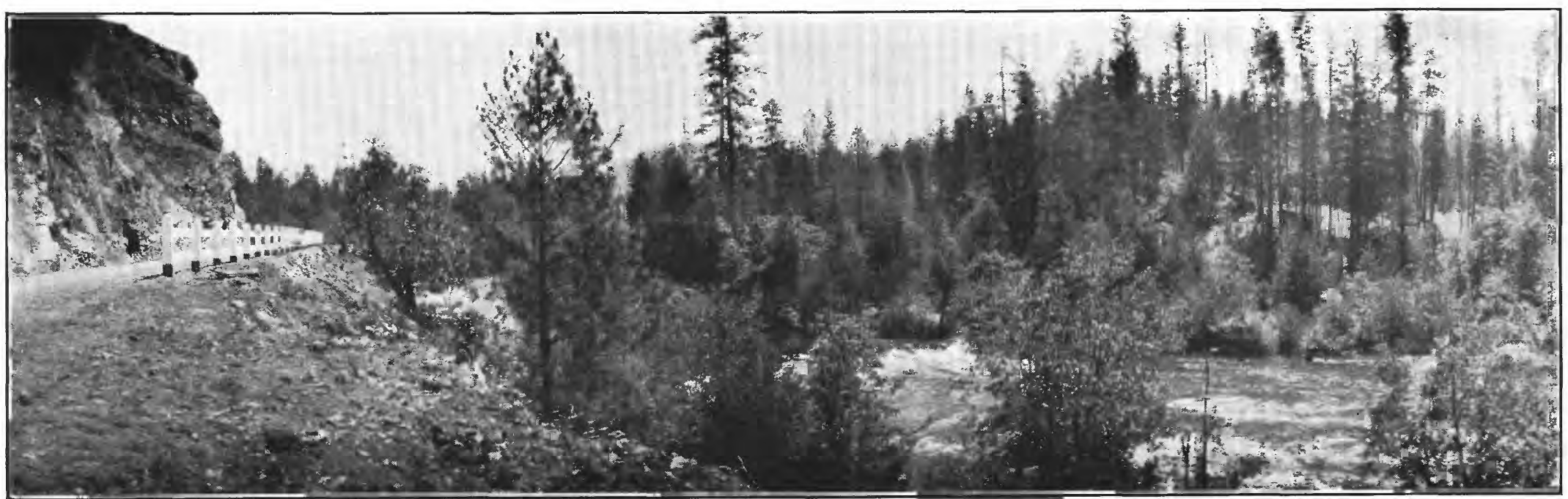

B. BUTTE CREEK DAM SITE, ROGUE RIVER BASIN 


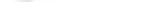


upstream. The lava tube, or cavern, at this place carries the entire summer flow of the Rogue River underground, about 500 cubic feet a second. If such a tube occurred in the intracanyon basalt at a low level east of the Lost Creek dam site it would probably mean total failure of the Lost Creek reservoir, because its great depth below the surface and the probability of other smaller tubes associated with it would prevent its being filled with concrete at a cost commensurate with the value of the dam site. The width and thickness of the intracanyon basalt east of the site are too great to allow interception of the leakage by means of a cut-off wall or by grouting; consequently, any dam designed for this site must allow for possible leakage.

Although this site is unfavorable geologically, it is worth a detailed investigation, which should include drilling. It certainly should be included as a feasible site in the major program of power development along the Rogue, because as a power reservoir it can stand considerable leakage before being considered a failure. The time required for the passage of the water underground would help to regulate the flow of the river, and the amount of leakage would probably form only a small portion of the total flow of the river and might not exceed the amount of water that would of necessity have to be released. The basalt through which the water would pass is not soluble, hence there is little danger of the erevices enlarging by solution. Most of the seepage would doubtless return to the river above McLeod Bridge. It appears that the flow of the Rogue River is sufficient to fill the reservoir, although very little water might pass over the dam except in flood time. For this reason any large leakage would probably mean that little or no power could be developed either at the dam or by carrying the overflow by conduit to the power-house site a mile below the dam.

The capacity at an altitude of 1,620 feet is only 4,000 acre-feet. (See fig. 9.) By maintaining this small storage in the reservoir a mean head of 128 feet will. be available at the dam. This head combined with that obtained by a pressure pipe a little over a mile long will enable a mean head of 153 feet to be used at a power house in the SE. $1 / 4$ sec. $27, T .33$ S., R. 1 E.

\section{Potential power at undeveloped site 12RD 8}

[Total head, 195 feet; assumed drawdown, 125 feet]

\begin{tabular}{l|r|r|r|r}
\hline & Flow (second-feet) & \multicolumn{2}{|c|}{ Horsepower } \\
\cline { 2 - 4 } & $\begin{array}{r}90 \text { per cent } \\
\text { of time }\end{array}$ & $\begin{array}{r}50 \text { per cent } \\
\text { of time }\end{array}$ & $\begin{array}{r}90 \text { per cent } \\
\text { of time }\end{array}$ & $\begin{array}{r}50 \text { per cent } \\
\text { of time }\end{array}$ \\
\hline $\begin{array}{l}\text { Natural flow .... } \\
\text { Regulated flow. }\end{array}$ & $\begin{array}{r}845 \\
1,140\end{array}$ & $\begin{array}{r}10,400 \\
1,690\end{array}$ & $\begin{array}{r}17,100 \\
20,700\end{array}$ \\
\hline
\end{tabular}

The damages incident to the reservoir construction have been considered in connection with the Lost Creek reservoir site. No additional damage will be caused by the power development as here outlined.

The maximum flood that may be expected at this point will not be very great and can be passed over the spillway or around or through the dam, as seems best when a detailed design is made.

\section{BUTTE CRERK POWER SITE (12RD 9)}

The Butte Creek power site is about half a mile below the mouth of Butte Creek. in the NE. $1 / 4$ sec. 33, T. 33 S., R. 1 E. (See fig. 12 and pl. 19, B.) Conditions here are favorable for the construction of a 30-foot dam to raise the water to the 
1,545-foot contour. The dam will be about 380 feet long on the crest and may be of an overflow section.

The site is excellent geologically, for the dam will be founded on dense black diabase that appears to be a thick water-tight intrusive dikelike mass. This diabase crops out continuously along the line of the dam, even in the river bed. On the upstream side of the dike there is about 10 feet of soft, weathered rock, and on the downstream side about 2 feet of similar material. These soft rocks
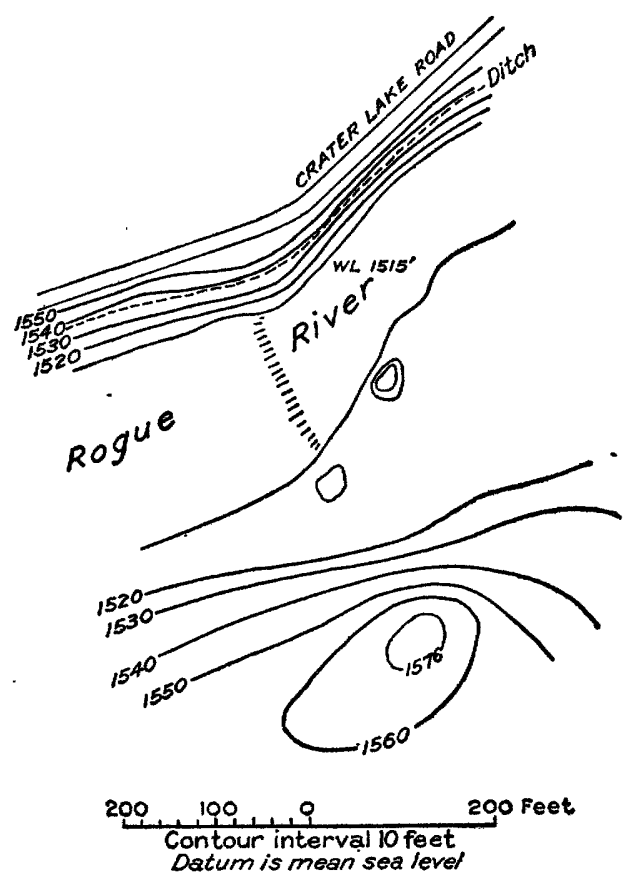

Figure 12.-Plan, Butte Creek dam site, Rogue River Basin may be the result of local metamorphism due to the intrusion of the diabase. In any event it is advisable to drill at the site to determine whether any of the soft material occurs in the line of the dam. No difficulty will be experienced in preventing seepage under or around the dam. The site is readily accessible, as the Crater Lake Highway runs past one end of the dam.

The pond will flood a small area of agricultural and meadow. land. It will also necessitate the relocation of about 1 mile of highway and half a mile of secondary road and the raising of the McLeod Bridge about 15 feet. It may be more desirable to abandon the old bridge and carry the traffic which is headed up Butte Creek across the top of the dam.

A canal 1.2 miles long constructed on the right bank along the 1,545-foot contour and a penstock 0.2 mile long will connect the dam with the power house in the center of sec. 32, T. 33 S., R. 1 E., and make a total head of 65 feet available.

Potential power at undeveloped site 12RD 9

\begin{tabular}{l|r|r|r|r}
\hline & Flow (second-feet) & \multicolumn{2}{|c|}{ Horsepower } \\
\hline & $\begin{array}{r}90 \text { per cent } \\
\text { of time }\end{array}$ & $\begin{array}{r}50 \text { per cent } \\
\text { of time }\end{array}$ & $\begin{array}{r}90 \text { per cent } \\
\text { of time }\end{array}$ & $\begin{array}{r}50 \text { per cent } \\
\text { of time }\end{array}$ \\
\hline Natural flow.... & $\begin{array}{r}\mathbf{9 2 0} \\
\text { Regulated flow. }\end{array}$ & $\begin{array}{r}1,660 \\
\mathbf{1 , 9 1 0}\end{array}$ & $\begin{array}{r}\mathbf{4}, \mathbf{7 8 0} \\
\mathbf{6 , 4 5 0}\end{array}$ & $\begin{array}{r}\mathbf{8 , 6 4 0} \\
\mathbf{9}, 940\end{array}$ \\
\hline
\end{tabular}

If the entire crest length of the dam is used as a spillway, the probable maximum flow may be passed with a rise in pond level between 5 and 6 feet.

The Eagle Point Irrigation District diverts about 70 second-feet from Butte Creek at Butte Falls. The discharge for 90 per cent of the time at the dam sites below has been reduced by this amount. A flume carrying about 2 second-feet is used to irrigate a small tract of land a short distance downstream from this site. No other diversions from the main stream exist above this point. 


\section{BLK CRERK POWER SITE (12RD 10)}

Between the Butte Creek and Trail Creek sites the fall of the Rogue River amounts to 60 feet in $3 \frac{1}{2}$ miles. The flow available at the Elk Creek site is the same as at the Butte Creek site. Construction of low dams or canals to develop the power would be expensive, and this site would be one of the last to be used. But the potential power exists, and probably some of it could be developed if a market were available. It is assumed that half of the head, or 30 feet, can some day be economically used, and the potential power of the site has been calculated on that basis.

Potential power at undeveloped site 12RD 10

\begin{tabular}{|c|c|c|c|c|}
\hline & \multicolumn{2}{|c|}{ Flow (second-feet) } & \multicolumn{2}{|c|}{ Horsepower } \\
\hline & $\begin{array}{l}90 \text { per cent } \\
\text { of time }\end{array}$ & $\begin{array}{l}50 \text { per cent } \\
\text { of time }\end{array}$ & $\begin{array}{l}90 \text { per cent } \\
\text { of time }\end{array}$ & $\begin{array}{l}50 \text { per cont } \\
\text { of time }\end{array}$ \\
\hline $\begin{array}{l}\text { Natural flow } \\
\text { Regulated flow }\end{array}$ & $\begin{array}{r}920 \\
1,240\end{array}$ & $\begin{array}{l}1,660 \\
1,910\end{array}$ & $\begin{array}{l}2,210 \\
2,980\end{array}$ & $\begin{array}{l}3,980 \\
4,580\end{array}$ \\
\hline
\end{tabular}

TRAII CREER POWER SITE (12RD 11)

The Trail Creek dam site is about 1.2 miles below the mouth of Trail Creek and a short distance above the middle of sec. 10, T. 34 S., R. 1 W. (See fig. 13 and pl. 20. C.) The proposed 25-foot dam will have an excellent foundation, for massive, dense basalt crops out on both banks and in the river bed. Although the basalt is considerably jointed, the joints appear to be tight, and no appreciable leakage for a dam of this height should occur. The site is readily accessible, as the Crater Lake Highway is adjacent to the west end of the dam.

By flooding to an altitude of 1,420 feet a head of 25 feet would be created without appreciable damage either to agricultural land in section 3 or to the highway. As the bottom lands are relatively flat; and as the highway is not very much above the pond level in places, it will be necessary to pass the maximum flood without any great increase in the water level above the dam. The crest length of the dam is 370 feet, and if this entire length were used as a spillway, the rise in pond level for the probable maximum flood would be about 8 feet. As it is desirable to limit the pond rise to about 5 feet, gates with an aggregate width of 80 feet and a depth below the spillway crest of 10 feet must be used to supplement the discharge of the overflow section of the spillway. The power house may be constructed at either end of the dam.

Potential power at undeveloped site 12RD 11

\begin{tabular}{|c|c|c|c|c|}
\hline & \multicolumn{2}{|c|}{ Flow (second-feet) } & \multicolumn{2}{|c|}{ Horsepowrer } \\
\hline & $\begin{array}{l}90 \text { per cent } \\
\text { of time }\end{array}$ & $\begin{array}{l}50 \text { per cent } \\
\text { of time }\end{array}$ & $\begin{array}{l}90 \text { per cont } \\
\text { of time }\end{array}$ & $\begin{array}{l}50 \text { per oent } \\
\text { of time }\end{array}$ \\
\hline $\begin{array}{l}\text { Natural flow } \\
\text { Regulated flow }\end{array}$ & $\begin{array}{l}1,030 \\
1,400\end{array}$ & $\begin{array}{l}1,860 \\
2,030\end{array}$ & $\begin{array}{l}2,060 \\
2,800\end{array}$ & $\begin{array}{l}3,720 \\
4,060\end{array}$ \\
\hline
\end{tabular}

LONG CREFK POWER SITIS (12RD 12)

Between the Trail Creek power site and the Reese Creek site there is a fall of 115 feet in $8 \frac{1}{2}$ miles, or $13 \frac{1}{2}$ feet to the mile. The valley through this section is wide and flat, and compared with other sites on the river appears to offer very unfavorable conditions for the use of this potential power. But if this site were 

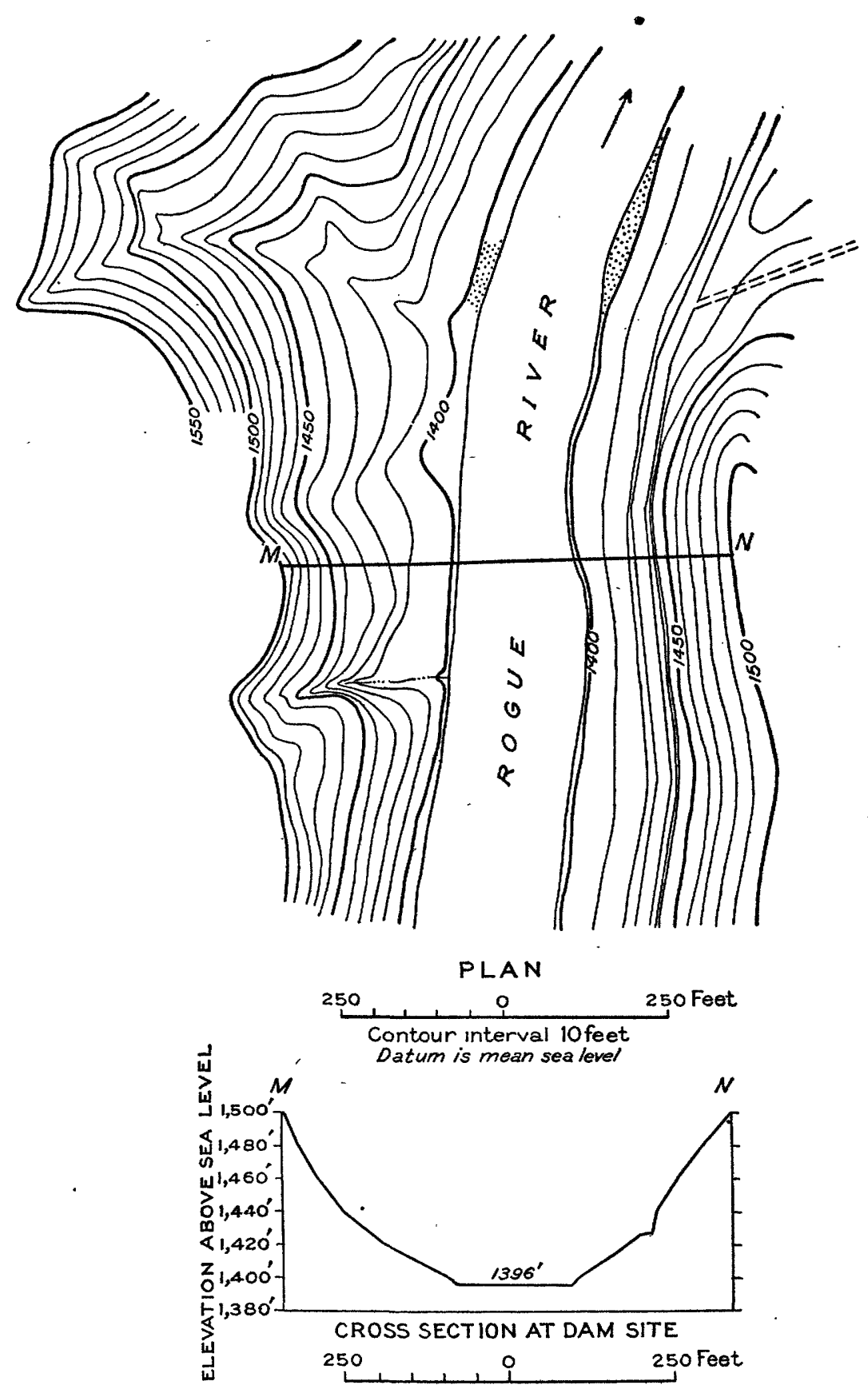

FrguRe 13.-Plan and cross section, Trail Creek dam site, Rogue River Basin 
located in an industrial section of the East or Middle West, it would soon be used, so it is possible that in 50 years sites in. Oregon similar to this will be put to use. The power will be developed by means of low dams, or low dams and cenduits. On account of unfavorable conditions it is assumed that only half of the head in this section can be developed, or 60 feet.

Potential power at undeveloped site 12RD 12

\begin{tabular}{|c|c|c|c|c|}
\hline \multirow[b]{2}{*}{ - } & \multicolumn{2}{|c|}{ Flow (second-feet) } & \multicolumn{2}{|c|}{ Horsepowex } \\
\hline & $\begin{array}{c}90 \text { per cent } \\
\text { of time }\end{array}$ & $\begin{array}{c}50 \text { per cent } \\
\text { of time }\end{array}$ & $\begin{array}{c}90 \text { per cent } \\
\text { of time }\end{array}$ & $\begin{array}{l}50 \text { per eent } \\
\text { of time }\end{array}$ \\
\hline $\begin{array}{l}\text { Natural flow } \\
\text { Regulated flow. }\end{array}$ & $\begin{array}{l}1,030 \\
1,420\end{array}$ & $\begin{array}{l}1,860 \\
\mathbf{2}, 030\end{array}$ & $\begin{array}{l}4,960 \\
6,820\end{array}$ & $\begin{array}{l}8,930 \\
9,740\end{array}$ \\
\hline
\end{tabular}

\section{REEST CREEK POWER SITE (12RD 13)}

A very low diversion dam or a wing dam could be built below the mouth of Reese Creek near the east line of sec. 17, T. 35 S., R. 1 W., to turn the water into an open canal 2.5 miles long, constructed along the left bank on the 1,280-foot contour. A penstock 0.10 mile long would connect the end of this canal with a power house in the SW. 1/4 sec. 29 of the same township. The total head created would be 43 feet. The stream flow at this site has been corrected by deducting 70 second-feet because of the irrigation diversion from Butte Creek.

Potential power at undeveloped site 12RD 13

\begin{tabular}{|c|c|c|c|c|}
\hline \multirow[b]{2}{*}{$\cdot$} & \multicolumn{2}{|c|}{ Flow (second-feet) } & \multicolumn{2}{|c|}{ Horsepower } \\
\hline & $\begin{array}{l}90 \text { per cent } \\
\text { of time }\end{array}$ & $\begin{array}{l}50 \text { per cent } \\
\text { of time }\end{array}$ & $\begin{array}{l}90 \text { per cent } \\
\text { of time }\end{array}$ & $\begin{array}{c}50 \text { per cent } \\
\text { of time }\end{array}$ \\
\hline $\begin{array}{l}\text { Natural flow } \\
\text { Regulated flow. }\end{array}$ & $\begin{array}{l}1,050 \\
1,430\end{array}$ & $\begin{array}{l}1,900 \\
2,050\end{array}$ & $\begin{array}{l}3,610 \\
4,920\end{array}$ & $\begin{array}{l}6,540 \\
7,040\end{array}$ \\
\hline
\end{tabular}

Practically no damage will be caused by this development. The site is readily accessible, and no difficulty should be experienced in constructing a canal and power house at the location indicated.

\section{ITTTLE BUTTE CREEK POWER SITE (12ED 14)}

At the Little Butte Creek power site a low diversion dam could be built in the SW. $1 / 4$ sec. 7, T. 36 S., R. 1 W., to divert water into a ditch at an altitude of 1,200 feet. Four miles of canal along the left bank would carry the water to the SW. $1 / 4$ sec. 15, T. 36 S., R. 2 W., where a head of 35 feet would be obtained. The canal would probably require lining in places because it approaches so near to the river; otherwise this project should be comparatively inexpensive. The discharge would be about the same as at Raygold, which is the site next below.

Potential power at undeveloped site 12RD 14

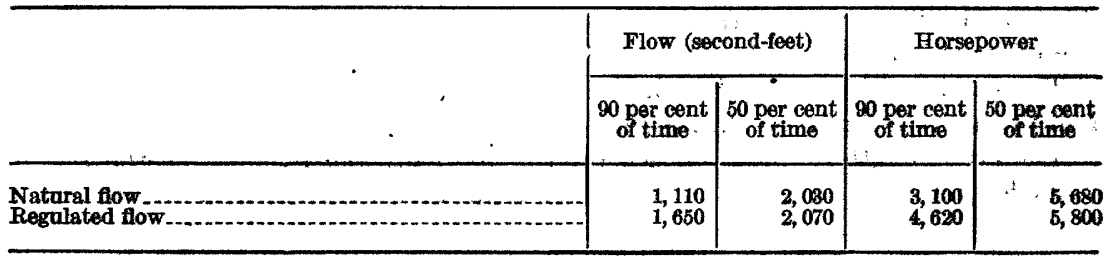


GOID FIIL POWRR SITE (12RD 16)

The Gold Hill power site can be developed by building a dam 13 feet high in the NW. $1 / 4$ sec. 11, T. 36 S., R. 3 W., to flood to the $1 ; 100$-foot contour and by constructing an open canal along the 1,100-foot contour on the left bank of the river a distance of $\mathbf{2 . 6}$ miles, with a penstock half a mile long connecting the end of the canal with a power house in the NW: $1 / 4$ sec. 22 . A total head of 65 feet would be created.

At the dam site bedrock extends across the river (see pl. 18, B) and a very shallow excavation would permit the structure to be securely anchored to the rock. No difficulty will be experienced in preventing seepage under or around the dam. As the main line of the Southern Pacific Railroad passes one end of the dam the delivery of material will be very simple.

Potential power at undeveloped site 12RD 16

\begin{tabular}{|c|c|c|c|c|}
\hline & \multicolumn{2}{|c|}{ Flow (second feet) } & \multicolumn{2}{|c|}{ Horsepower } \\
\hline & $\begin{array}{c}90 \text { per cent } \\
\text { of time }\end{array}$ & $\begin{array}{l}50 \text { per cent } \\
\text { of time }\end{array}$ & $\begin{array}{l}90 \text { per cent } \\
\text { of time }\end{array}$ & $\begin{array}{l}50 \text { per cent } \\
\text { of time }\end{array}$ \\
\hline $\begin{array}{l}\text { Natural flow } \\
\text { Regulated flow }\end{array}$ & $\begin{array}{l}1,110 \\
1,670\end{array}$ & $\begin{array}{l}2,190 \\
2,190\end{array}$ & $\begin{array}{l}5,770 \\
8,690\end{array}$ & $\begin{array}{l}11,400 \\
11,400\end{array}$ \\
\hline
\end{tabular}

Practically no damage will be done to existing or proposed improvements by flooding to the 1,100-foot contour. In order, however, that possible damage to the railroad right of way, the wagon road, and the agricultural land in sec. 12 may be avoided, it seems desirable that the fluctuation in pond level due to high water shall be limited to about 10 feet. The crest length of the dam will be 500 feet, and the maximum flood to be passed will be much the same as that at Raygold. By using gates cut 10 feet below the crest of the dam and having an aggregate length of 150 feet and by constructing the remainder of the dam as an overflow section, the maximum flood can be passed without raising the pond level more than 10 feet.

\section{ROCK POINT POWER SITE (12RD 17)}

The Rock Point power site is 2 miles west of the town of Gold Hill and about 300 feet upstream from Rock Point Bridge. (See pl. 20, B.)

Bedrock is well exposed on both banks and lies at a shallow depth below the river bed. A microscopic examination of a specimen from this site made by C. S. Ross, of the United States Geological Survey, showed the rock to be profoundly metamorphosed, possibly of the diorite type. This rock will form an excellent foundation for the proposed dam, as the joints are fairly tight, and any seepage through them will be slight.

By constructing a 16-foot dam in the NW. $1 / 4$ sec. 20 , T. $36 \mathrm{~S} .$, R. $3 \mathrm{~W}$., to flood to an altitude of 1,030 feet, and a canal about 800 feet long on the left bank, a total head of 18 feet would be made available. The 2 -foot additional head obtained by the canal might not ordinarily justify its construction, but directly under the bridge the river channel is only about 60 feet wide, and in time of high water the constricted opening would probably cause considerable backwater. The canal will carry the water past this place and return it to the river where the channel is much wider.

The site is readily accessible, as the main line of the Southern Pacific Railroad and the highway between Grants Pass and Medford both pass one end of the dam.

The crest length of the proposed dam is 300 feet, and by limiting the rise in pond level to 10 feet no damage will be done to existing improvements. The 
banks are of solid rock, and water may be passed over them without danger. The river side of the canal between the dam and the bridge should be designed as an overflow section in order that it may assist the rest of the dam in passing floods. If the main dam is also designed as an overflow section the total spillway length will be about 850 feet, and the probable flood flow can be passed with an increase in pond level of 9 or 10 feet.

Potential power at undeveloped site 12RD 17

\begin{tabular}{|c|c|c|c|c|}
\hline & \multicolumn{2}{|c|}{ Flow (second-feet) } & \multicolumn{2}{|c|}{ Horsepower } \\
\hline & $\begin{array}{l}90 \text { per cent } \\
\text { of time }\end{array}$ & $\begin{array}{l}50 \text { per cent } \\
\text { of time }\end{array}$ & $\begin{array}{l}90 \text { per cent } \\
\text { of time }\end{array}$ & $\begin{array}{c}50 \text { per cept } \\
\text { of time }\end{array}$ \\
\hline $\begin{array}{l}\text { Natural flow } \\
\text { Regulated flow }\end{array}$ & $\begin{array}{l}1,130 \\
1,690\end{array}$ & $\begin{array}{l}2,210 \\
2,210\end{array}$ & $\begin{array}{l}1,630 \\
2,430\end{array}$ & $\begin{array}{l}\mathbf{3}, \mathbf{2 8 0} \\
\mathbf{3}, \mathbf{2 8 0}\end{array}$ \\
\hline
\end{tabular}

\section{AMENT POWER SITE (12RD 19)}

The Ament power site is in the NW. $1 / 4$ sec. 23, T. 36 S., R. 5 W. (See pl. $20, A$.) At this point there are the ruins of an old rock-fill timber-crib dam and also a concrete power house and wing wall. At some time in the past a section of the dam adjacent to the power house was washed out. The concrete is still in good shape, and it appears that the timber portion of the dam could be made serviceable with minor repairs. The washed out portion appears to have been founded on bedrock, and there is no good reason why it should not have remained in place had it been properly anchored. The south end of the dam is founded on cemented gravel. This material is fairly stable, but in case of reconstruction it should be protected from backwash, as the south bank directly below the dam is composed of the same material and is cutting rather badly. By repairing the dam a head of 15 feet would be made available.

Potential power at undeveloped site 12RD 19

\begin{tabular}{|c|c|c|c|c|}
\hline & \multicolumn{2}{|c|}{ Flow (second-feet) } & \multicolumn{2}{|c|}{ Horsepower } \\
\hline & $\begin{array}{l}90 \text { per cent } \\
\text { of time }\end{array}$ & $\begin{array}{c}50 \text { per cent } \\
\text { of time }\end{array}$ & $\begin{array}{c}90 \text { per cent } \\
\text { of time }\end{array}$ & $\begin{array}{l}50 \text { per cent } \\
\text { of time }\end{array}$ \\
\hline $\begin{array}{l}\text { Natural flow } \\
\text { Regulated flow. }\end{array}$ & $\begin{array}{l}1,130 \\
1,670\end{array}$ & $\begin{array}{r}\mathbf{2}, \mathbf{1 9 0} \\
\mathbf{2 , 1 9 0}\end{array}$ & $\begin{array}{l}1,350 \\
2,000\end{array}$ & $\begin{array}{l}2,630 \\
2,630\end{array}$ \\
\hline
\end{tabular}

In order that backwater from this site may not cause damage, the pond here should not be raised more than 5 feet. If a 200 -foot section of the dam adjacent to the power house were replaced by a gate section with the gate sills about on a level with the rock bottom floods could probably be passed without exceeding the 5-foot limit. The opening of the gates would practically wipe out the head on the wheels, but the excessive flow would then be confined to the part of the stream bed best suited to withstand it, and as the floods are usually of short duration the power loss would be small.

Between the tail water of the Ament Dam and backwater from the proposed dam at Taylor Creek there is a fall of 100 feet in 18 miles, or about $5 \frac{1 / 2}{2}$ feet to the mile. This head could be developed by increasing the height of the Taylor Creek Dam, but the damages to agricultural land would be too great. Conduits also would be too expensive with so slight a fall to the mile. It is possible that low dams could be constructed to use part of this head, but such development will not take place for many years; therefore the potential power value of this section 
has been disregarded in this report and in the tabulation showing the power value of the Rogue River.

HELI GATE POWER SITE (12RD 20) AND TAYLOR CREEK POWRR SITE (12RD 21)

As the Hell Gate and Taylor Creek projects overlap to a considerable extent and as only one of the sites can be economically developed they will be considered together.

The Hell Gate dam site is in sec. 10, T. 35 S., R. 7 W., at the entrance to a narrow, rugged canyon in which the Rogue River flows on its way through the Coast Range. (See pl. 14, B.) Massive jointed green rock crops out on both abutments and probably lies not more than 30 feet below the surface of the river. A specimen from this site was examined under the microscope by C. S. Ross and was found to be a profoundly metamorphosed rock containing secondary epidote, clinozoisite, and actinolite. The site is excellent because seepage will cause no difficulty, and the rock is sufficiently strong to support a 200-foot dam.

The Taylor Creek site is farther downstream, in sec. 10, T. 35 S., R. 7 W. (See pls. 12 and 13, B.) Both upstream and downstream from this site the valley is wider, owing to the occurrence of soft black schist. The narrows at the spot selected for the dam is due to the outeropping of massive rock, which forms rugged cliffs on both sides of the stream. This rock is green and megascopically appears to be a metamorphosed conglomerate. The alteration has been so complete that all signs of the original sedimentary bedding planes have disappeared. This rock has a high crushing strength and would form excellent abutments for a dam 200 feet high. The joints are tight, and only ordinary precautions will be required to prevent leakage.

The physical conditions at the two sites are much the same. The sections are narrow, the abutments are massive, and the depth to bedrock in the river channel is probably not more than 25 to 30 feet. A 200 -foot dam could be built at either place, and no trouble would be experienced in preventing seepage either around or under the dam. The Hell Gate site is slightly more accessible, as it is only 6 miles from Merlin, the nearest railroad station; the Taylor Creek site is about 9 miles from the railroad, but as a fairly good highway runs past both sites the difference is not great. As a dam at the lower site could be built 29 feet higher than one at the upper site with practically no greater damage it seems probable that the lower (Taylor Creek) site is preferable.

To flood to the 900-foot contour would require a 153-foot dam at Hell Gate or a 182-foot dam at Taylor Creek. The area flooded would be about 10,000 acres for either site. The features of the reservoir site have been described on page 62 . This area lies directly below the town of Grants Pass; practically all the land below the 900-foot contour is cultivable and irrigable, and a large part of it is now in use for the raising of hops and orchard products. The agricultural value of the land is high, and its use for flowage can not be justified.

A dam could be built to raise the water 82 feet, to the 800 -foot contour. This would flood only 560 acres of land, most of which lies in the narrow bottom of the canyon, where its value is low. It is doubtful whether the added power that could be produced by a greater head would pay for the additional damages incurred. Aside from the slight area of agricultural land flooded by an 82-foot dam the only additional damage would be the destruction of about 2 miles of highway and possibly two or three houses. The relocation of the highway would involve no particular difficulty. 
U. S. GEOLOGICAL SURVEY

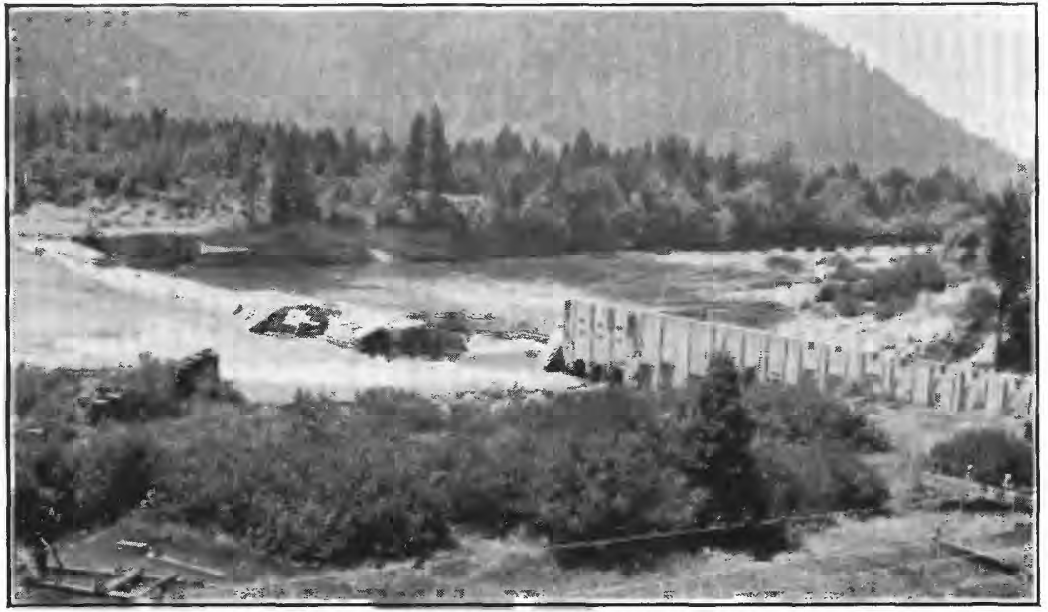

A. AMENT DAM, ROGUE RIVER ABOVE GRANTS PASS

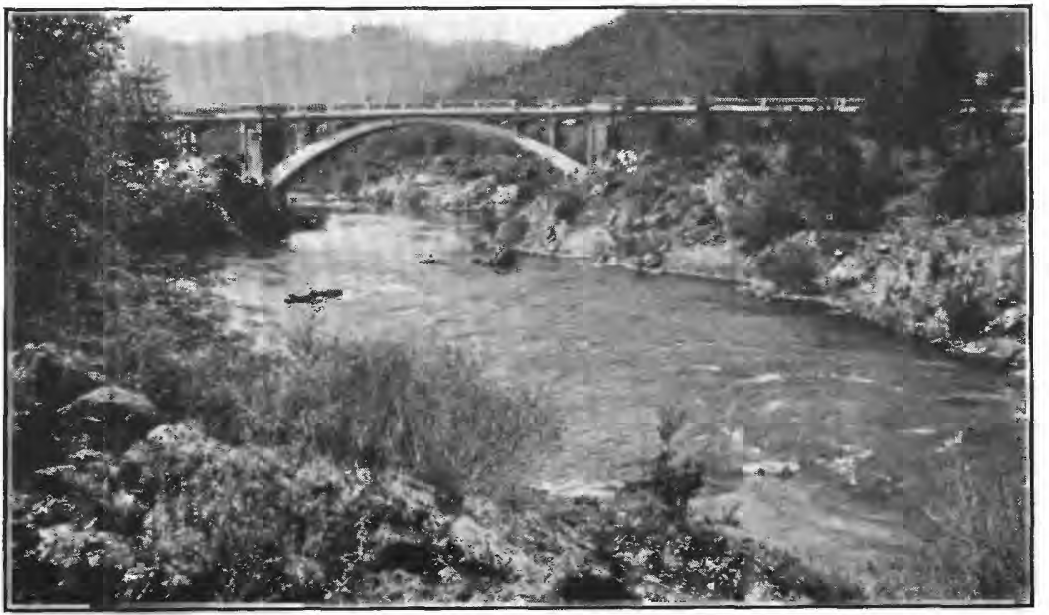

B. ROCK POINT DAM SITE, ROGUE RIVER BASIN

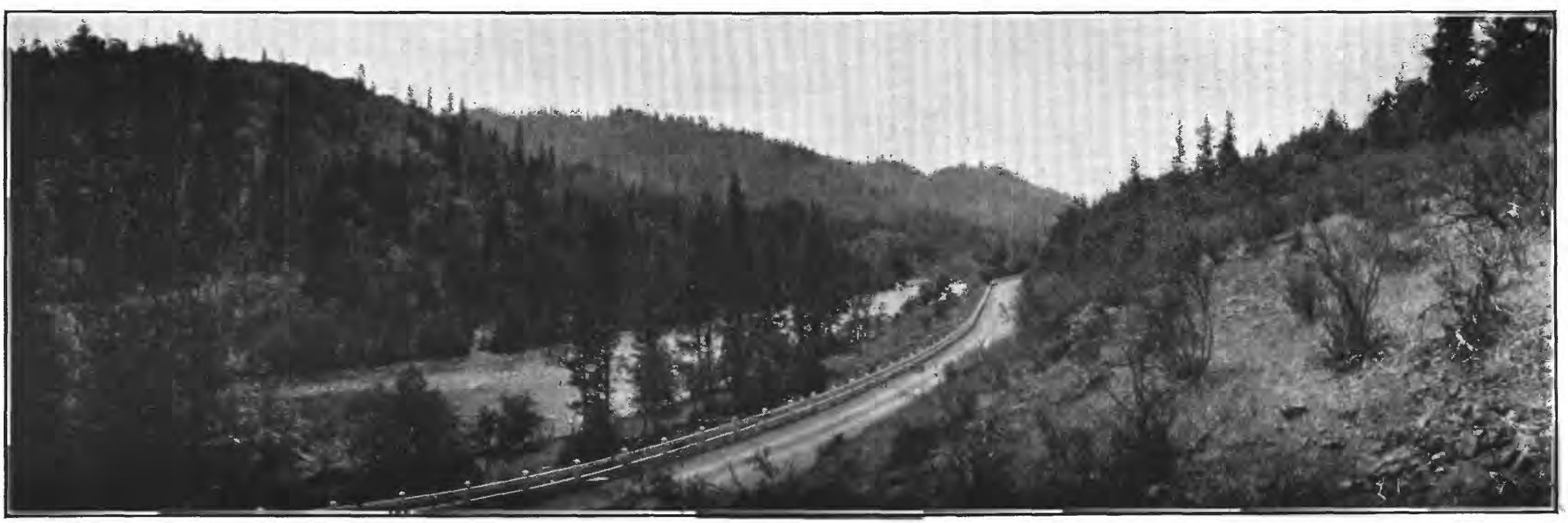

C. TRAIL CREEK DAM SITE, ROGUE RIVER BASIN 



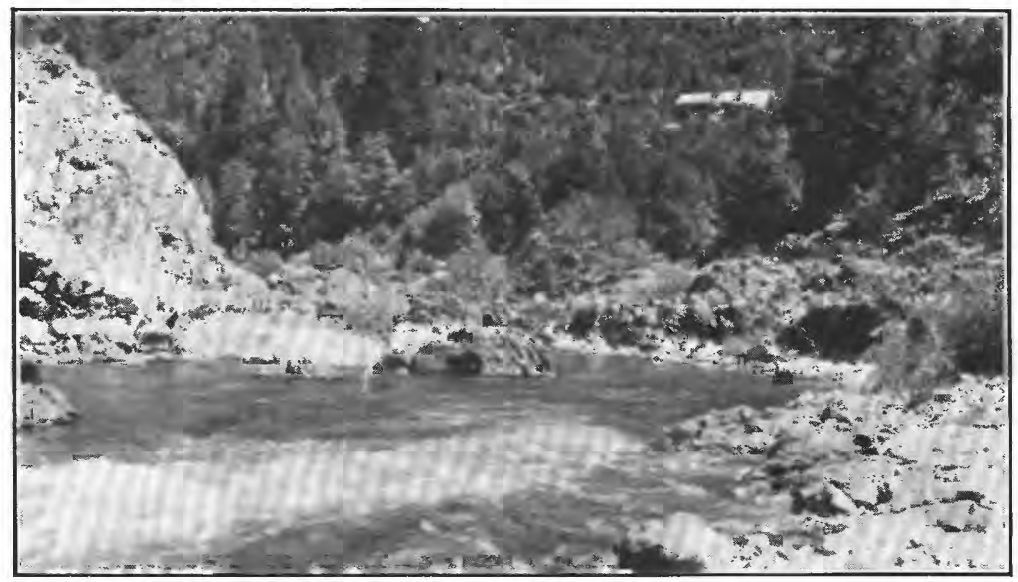

A. HORSESHOE BEND DAM SITE, ROGUE RIVER BASIN

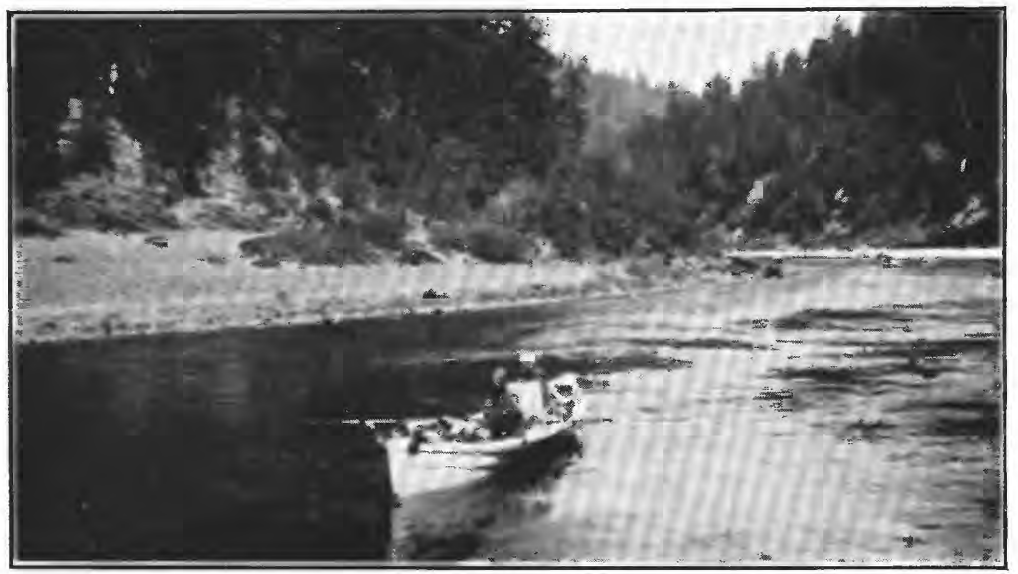

B. ROGUE RIVER 2 MILES ABOVE MULE CREEK

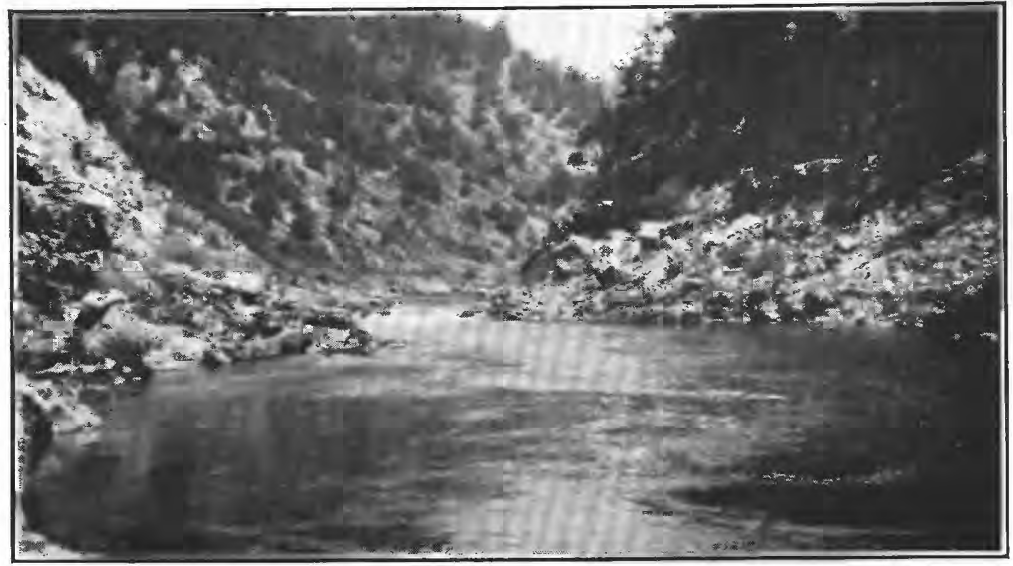

C. SWING BRIDGE DAM SITE, JUST BELOW GRAVE CREEK, ROGUE RIVER BASIN 


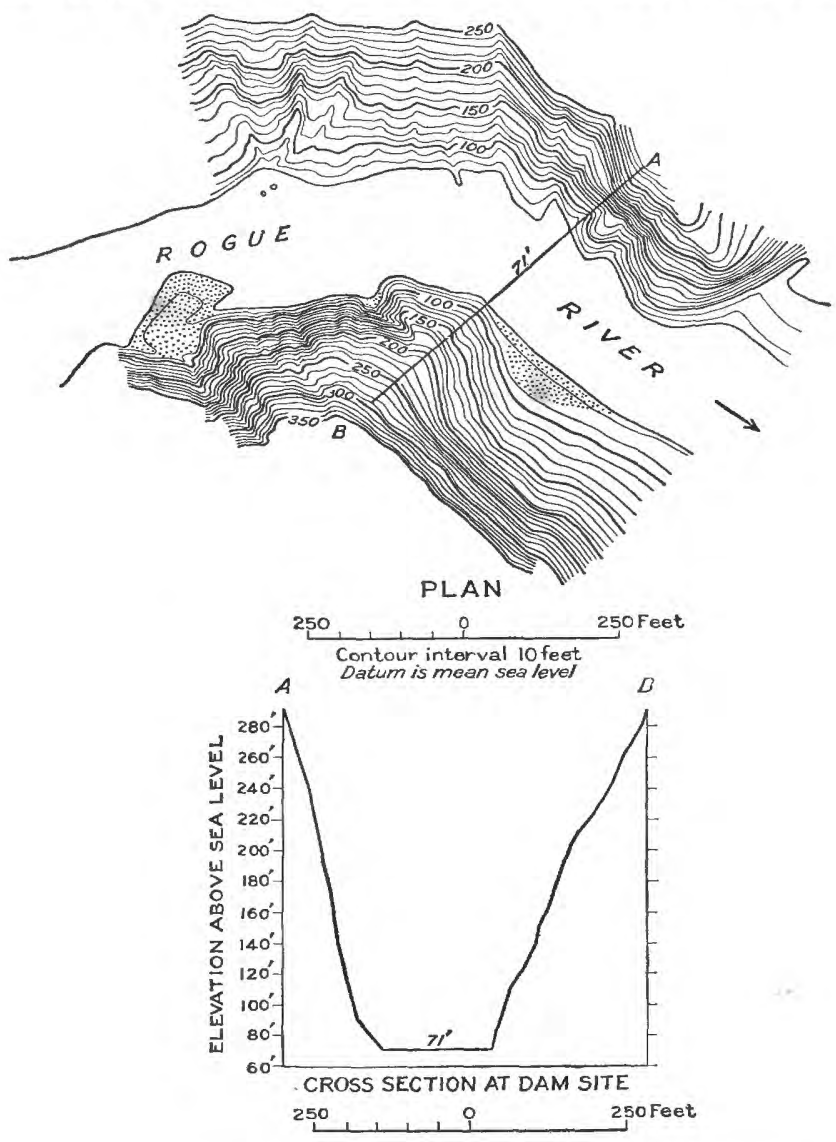

CAPACITY IN HUNDRED THOUSANDS OF ACRE-FEET

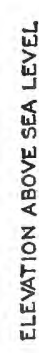

4

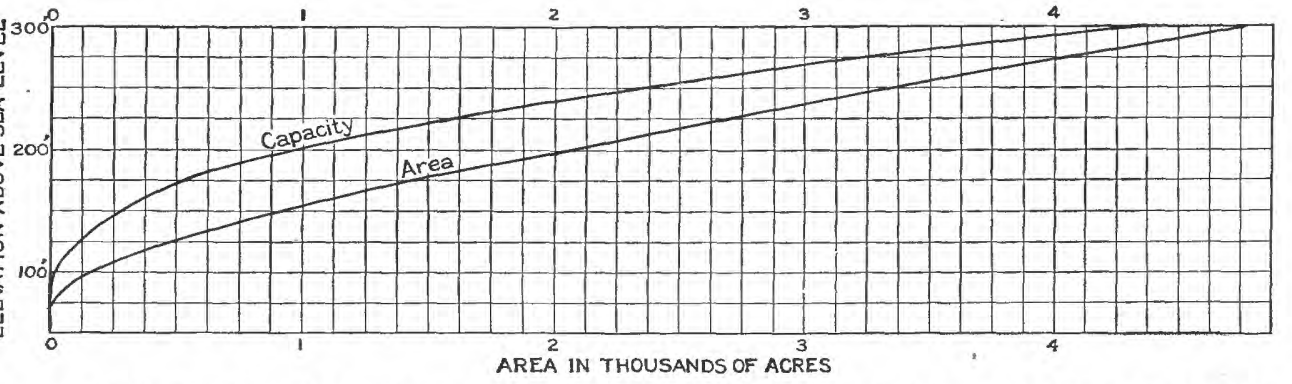

PLAN, CROSS SECTION, AND AREA AND CAPACITY CURVES, COPPER CANYON POWER SITE, ROGUE RIVER BASIN 

Potential power at undeveloped site 12RD 21

\begin{tabular}{l|r|r|r|r}
\hline & \multicolumn{2}{|c|}{ Flow (second-feet) } & \multicolumn{2}{|c}{ Horsepower } \\
\hline & $\begin{array}{r}90 \text { per cent } \\
\text { of time }\end{array}$ & $\begin{array}{r}50 \text { per cent } \\
\text { of time }\end{array}$ & $\begin{array}{r}90 \text { per cent } \\
\text { of time }\end{array}$ & $\begin{array}{c}50 \text { per cent } \\
\text { of time }\end{array}$ \\
\hline Natural flow ..... & $\begin{array}{l}1,020 \\
2,400\end{array}$ & 2,970 & $\begin{array}{r}6,700 \\
15,700\end{array}$ & $\begin{array}{r}19,500 \\
19,500\end{array}$ \\
\hline
\end{tabular}

An overflow-type dam is suggested for this site, and the power house should probably be located on the left bank of the river in the cove about 0.1 mile below the dam, where it will be somewhat protected from the floods. The crest length of the dam will be 270 feet, and this length will not increase appreciably as the pond rises. An increase of about 30 feet in the level of the water above the dam will permit the passage of the probable maximum flood. The added area flooded by this rise of pond level will be between 1,100 and 1,200 acres, but as the flood will be of short duration and as it is to be expected at infrequent intervals the damage will be low.

A drawdown of 10 feet at this site would provide 5,000 acre-feet of stored water, which could be used through an average head of 78 feet at this site and a total head of 663 feet including sites lower down. On the assumption that there would be no drawdown at the lower sites and that the period of drawdown at this site would average three months, the net gain at all sites would amount to $1,500,000$ kilowatt-hours if there were no regulation of the flow above this site and to less than 1,000,000 kilowatt-hours if all proposed reservoirs above were constructed. If the sites lower down on the river were not developed it would not pay to draw down the head for any considerable period, as the loss of power due to loss of head would soon equal the power obtained from the stored water.

\section{SWING BRIDGE POWER SITE (12RD 22)}

A dam at the Swing Bridge site, in the NE. 1/4 sec. 2, T. 34 S., R. 8 W., just below Grave Creek, would flood to an altitude of 700 feet and create a head of 107 feet. (See pl. 21, C.)

A fine-grained green rock of igneous origin containing nodules 3 to 6 inches in diameter crops out as rocky ledges and eliffs on both abutments. A specimen of one of these nodules was determined under the microscope by $C$. $\mathbf{S}$. Ross to be $\mathrm{a}$ greatly altered volcanic rock containing much epidote, with the feldspar phenocrysts almost completely broken down into a secondary aggregate but remaining fairly firm and coherent. Such a rock, although considerably altered, makes an excellent foundation for any dam of practicable height. Slight leakage may occur through the joints in the rock unless a small amount of cement grouting is done, but grouting is not absolutely necessary, for the seepage will not increase with time. The abutments are exposed, and the depth to bedrock in the channel is probably not over 20 feet.

The pond formed will be long and narrow and will flood no valuable lands. The only damage incident to development will be the inundation of about 0.7 mile of highway, 3 miles of trail, and a few houses.

To make the site readily accessible it would be necessary to build about 5 miles of highway connecting the dam with the highway already constructed as far as Almeda; or a road might be built down Grave Creek from the railroad station at Leland to the dam site, a distance of possibly 9 miles. 
Potential power at undeveloped site 12RD 22

\begin{tabular}{|c|c|c|c|c|}
\hline & \multicolumn{2}{|c|}{ Flow (second-feet) } & \multicolumn{2}{|c|}{ Horsepower } \\
\hline & $\begin{array}{l}90 \text { per cent } \\
\text { of time }\end{array}$ & $\begin{array}{l}50 \text { per cent } \\
\text { of time }\end{array}$ & $\begin{array}{l}90 \text { per cent } \\
\text { of time }\end{array}$ & $\begin{array}{l}50 \text { per cent } \\
\text { of time }\end{array}$ \\
\hline $\begin{array}{l}\text { Natural flow } \\
\text { Regulated flow. }\end{array}$ & $\begin{array}{l}\mathbf{1}, \mathbf{0 3 0} \\
\mathbf{2 , 4 1 0}\end{array}$ & $\begin{array}{l}3,130 \\
3,130\end{array}$ & $\begin{array}{r}8,800 \\
20,600\end{array}$ & $\begin{aligned} 26,800 \\
26,800\end{aligned}$ \\
\hline
\end{tabular}

The crest length of the dam, which should probably be of an overflow section, is about 500 feet. A rise in pond level of about 20 feet would enable the probable maximum flood to be passed if the entire crest were used as a spillway. In order, however, that the power house, which will be set into the bank directly below the dam, may not be injured by the extreme flow, some gates should be provided to throw the greater portion of the water to the opposite side of the river.

A drawdown of 40 feet at this site would make available 15,500 acre-feet of stored water, which could be used through an average head of about 90 feet at this site and a total head of $\mathbf{5 6 8}$ feet including sites lower down. Assuming that there would be no drawdown except at this site and that the period of drawdown would be three months, the net gain from drawing down the pond level would amount to 3,500,000 kilowatt-hours at all sites, without storage above; but if all the proposed storage sites were developed the loss of power due to loss of head would equal the total gain from the use of stored water and it would not pay to draw down the head. If the site were developed as a single unit with no storage above, it would not pay to draw down the head except for short periods.

\section{HORSESHOE BEND POWER SITE (12RD 28)}

By constructing a rock-filled dam at Horseshoe Bend, in the SW. $3 / 4$ sec. 23 and the NW.1/4 sec. 26 , T. 33 S., R. 9 W., to flood to the 580-foot contour, a head of 128 feet would be created.

The site selected for the dam is at a horseshoe bend where the river flows around a narrow low ridge of blue quartzite. (See fig. 14 and pl. 21, A.) The two abutments are cliffs of the quartzite, which crops out continuously across the low-stage channel, except near the end of the ridge, where it may be $\mathbf{3 0}$ feet below the water surface. The quartzite is shot through with quartz veins, and on the east abutment there is a quartz vein about 6 feet wide that forms a low short hogback. Metamorphism has nearly obliterated the bedding planes that formerly existed in the sediments. The rock is strong; no difficulty should be experienced with seepage under or around the dam.

A slight excavation would expose the abutments, and the depth to bedrock in the river channel is probably not more than 25 feet. A concrete dam might be as economical as the rock-fill type suggested, but owing to the presence of rock suitable for a dam and the comparative inaccessibility of the site, a rock-fill dam appears preferable, especially as the low point in the promontory around which the river flows can be used as a natural spillway.

Aside from the flooding of a short length of trail no damage will be done by this development. 

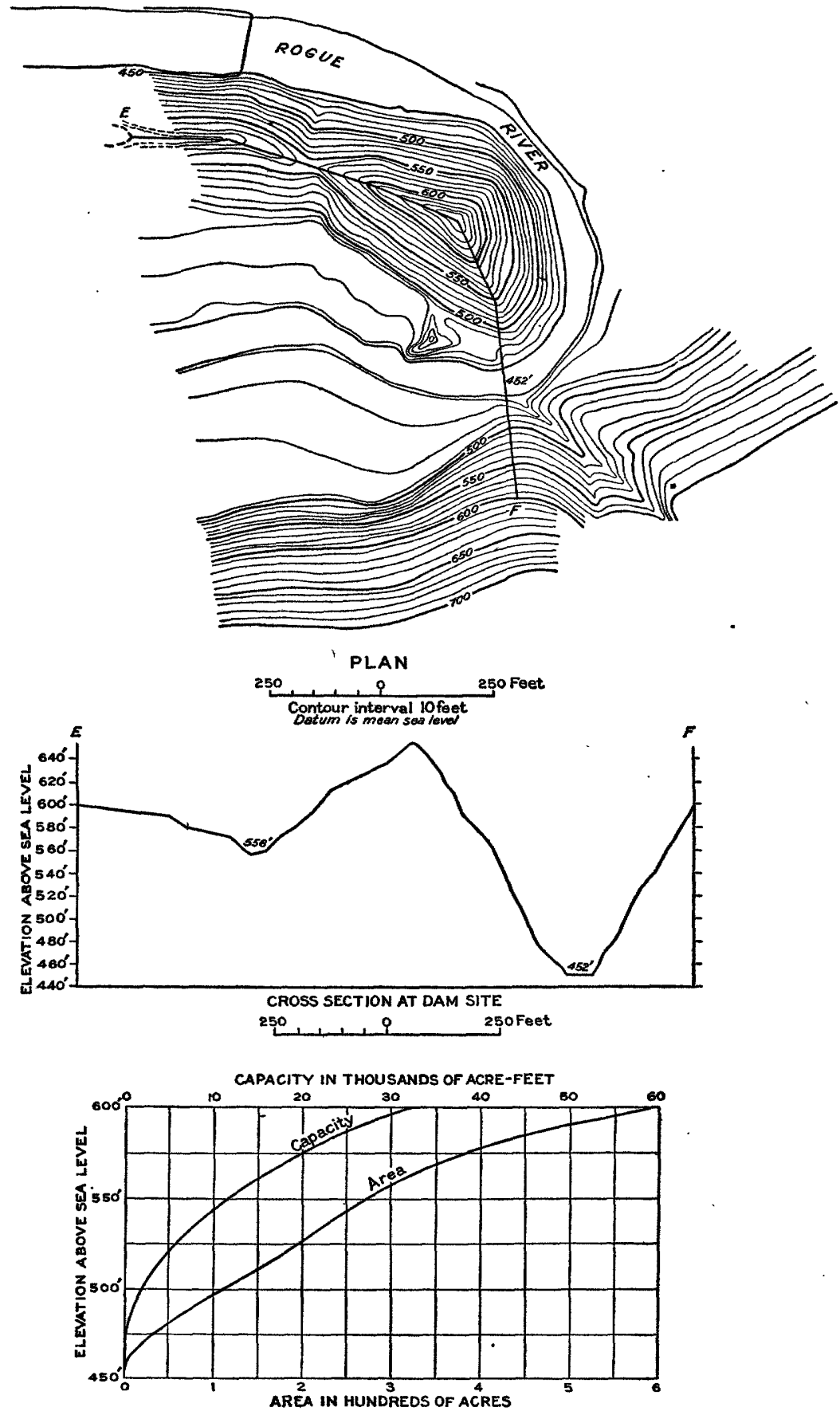

FraukR 14,-Plan, cross section, and area and capacity curves, Horseshoe Bend power site, Rogue River Basin 
Potential power at undeveloped site 12RD 23

\begin{tabular}{|c|c|c|c|c|}
\hline & \multicolumn{2}{|c|}{ Flow (second-feet) } & \multicolumn{2}{|c|}{ Horsepower } \\
\hline & $\begin{array}{l}90 \text { per cent } \\
\text { of time }\end{array}$ & $\begin{array}{l}50 \text { per cent } \\
\text { of time }\end{array}$ & $\begin{array}{c}90 \text { per cent } \\
\text { of time }\end{array}$ & $\begin{array}{l}50 \text { per cent } \\
\text { of time }\end{array}$ \\
\hline $\begin{array}{l}\text { Natural flow } \\
\text { Regulated flow }\end{array}$ & $\begin{array}{l}1,060 \\
2,440\end{array}$ & $\begin{array}{l}3,200 \\
3,200\end{array}$ & $\begin{array}{l}10,800 \\
25,000\end{array}$ & $\begin{array}{l}32,800 \\
32,800\end{array}$ \\
\hline
\end{tabular}

It is possible to construct a spillway 450 feet long in the saddle of the promontory. By cutting down the high part of the ridge to an altitude of $\mathbf{5 7 0}$ feet and building up the low part to the same height and installing gates in this section the maximum probable flood can be passed without exceeding a 15-foot rise in pond level. The bank down which the water will be run is composed of massive rock with few faults and probably will require no protection. If plucking takes place, however, the bad spots can readily be repaired with cement. By drawing down the head 30 feet 10,000 acre-feet of stored water would be obtained. This could be used through a head of 115 feet at this site and a total head of 465 feet if all proposed sites below were developed. On the assumption that there would be no drawdown at sites lower down and that the period of drawdown would be three months, the net gain from drawing down the pond level would be less than 1,000,000 kilowatt-hours. If all proposed reservoirs above were developed, or if the sites below were not developed, it would not pay to draw down the head at this site except for short periods.

To prevent any danger of overflow the crest of the dam should be raised to an altitude of 600 feet. The power house may be built on the flat rock bench immediately below the dam, but it should be at a height sufficient to prevent damage due to backwater, which may rise as much as 45 feet above normal low water.

\section{STAIRS CRERK POWER SITR (12RD 24)}

The Stairs Creek dam site is in the SE. $1 / 4$ sec. 17, T. 33 S., R. 10 W., in a rugged canyon carved out of massive diorite, an ancient igneous intrusion. (See fig. 15 and pls. $21, B, 23$, and $25, B$.) In places the diorite contains quartz veins and a few joints. The diorite is exposed without soil cover on both abutments, but bedrock in the river at this site may lie as much as $\mathbf{4 0}$ feet below the surface of the river. It is an admirable site for a dam, both because of the strength of the rock, its freshness at the surface, and the absence of many joints. By constructing a dam at this point to flood to an altitude of 440 feet a head of 150 feet will be created. The land to be flooded all lies in the bottom of a narrow canyon and is practically worthless. Aside from the flooding of about 3 miles of trail and several shacks no actual damage would be done.

Potential power at undeveloped site 12RD 24

\begin{tabular}{l|r|r|r|r}
\hline & Flow (second-feet) & \multicolumn{2}{|c|}{ Horsepower } \\
\hline & $\begin{array}{r}90 \text { per cent } \\
\text { of time }\end{array}$ & $\begin{array}{c}50 \text { per cent } \\
\text { of time }\end{array}$ & $\begin{array}{c}90 \text { per cent } \\
\text { of time }\end{array}$ & $\begin{array}{c}50 \text { per cent } \\
\text { of time }\end{array}$ \\
\hline Natural flow & 1,100 & 3,250 & 13,200 & 29,000 \\
\hline
\end{tabular}


As the crest length of the dam will be only about 320 feet, considerable diffculty will be experienced in passing, the expected floods. By construoting the headrace canal along the left bank and designing the outer wall as an overfow section the effective spillway length may be increased to about 450 feet. If the central 200 feet of the dam is constructed as a gate section with the gate sills 20
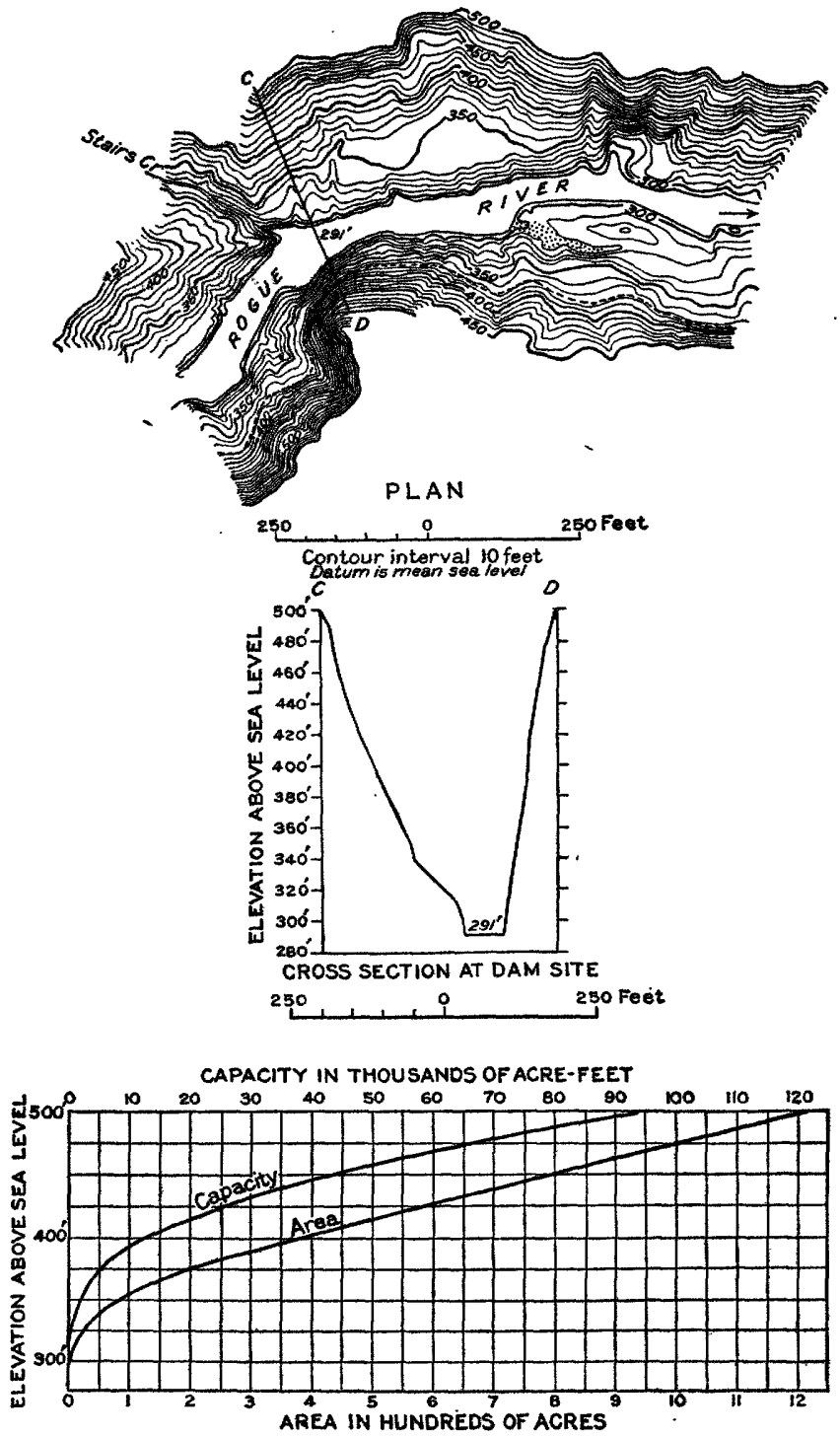

Fiauki 15.-Plan, cross section, and area capacity curves, Stairs Creek power site, Rogue River Basin

feet below the crest of the remainder of the dam the flood can be passed with an increase in pond level of about 13 feet. The power house can be built on the left side of the river on the bench that lies 250 feet below the dam. To prevent possible damage by scour the structure should be placed near the rear of the bench, and a substantial wall should be constructed between it and the spillway. 
Backwater conditions during heavy floods will be severe, and a rise of $\mathbf{4 0}$ to $\mathbf{5 0}$ feet in the normal tail-water level may be expected. This rise may be somewhat decreased by improving the channel farther downstream, but as the duration of the flood is normally short it is doubtful whether added expense would be justified.

The site is extremely inaccessible, and though it would be possible to construct a railroad from Leland down Grave Creek and the Rogue River, the cost would be almost prohibitive. A much more economical method, provided the site at Copper Canyon is first developed, would be to ship material by the construction railroad which must be built to develop that site and then load it into - barges which would carry it on slack water a distance of about 21 miles, practically to the Stairs Creek dam site.

By drawing down the head-of this site 40 feet 22,000 acre-feet of stored water could be obtained. This could be used through a head of 130 feet at this site and through a total head of $\mathbf{3 3 0}$ feet at this site and Copper Canyon. With no drawdown at Copper Canyon and drawdown at this site during a period of three months, the net gain from drawing down the pond level would be about $1,250,000$ kilowatt-hours. If Copper Canyon were not developed or if- the storage reservoirs above were built it would not pay to draw down the head at this site except for short periods.

\section{COPPER CATYON POWER STTE (12RD 25)}

The Copper Canyon dam site is in the SW. 1/4 sec. 11, T. 35 S., R. 12 W. (See pls. 22 and 25, A.) By constructing a dam at this place to flood to the 270-foot contour a head of 200 feet will be created. The depth to bedrock in the river channel is probably less than 30 feet below mean low water.

The dam site is formed by a dike of dense diabase half a mile wide that strikes north, at right angles to the river. The diabase is minutely jointed, owing to the severe stresses it has undergone in the past periods of folding in this area, but it is neither vesicular nor cavernous, and seepage will be insignificant. As the dike rises from great depths and cuts across the grain of the sedimentary beds that lie upstream from the site, no leakage will occur from the reservoir. The dike is somewhat weathered, but a 5-foot excavation should yield fresh rock. The geology and type of rock make this site almost ideal for any dam of practicable height. The crest of the dam will be 550 feet long, and the maximum probable flood can be passed over an overflow dam with a rise in pond level of about 27 feet. In order that the backwater shall not affect too much the Stairs Creek site above it is desirable that the flood be passed with a rise of about 10 feet. This can be accomplished by constructing a gate section 400 feet long in the dam and setting the gate sills 20 feet below the crest of the spillway.

A good site for the power house is in the little cove on the left bank of the river about 300 feet below the dam. Here it will be somewhat sheltered from the flood flow, and as the canyon widens rapidly below the cove the backwater should not be troublesome.

Copper Canyon is slightly more than 20 miles from the Pacific Ocean and the construction of a railroad for this distance involves no particular difficulty. This railroad will render the site readily accessible, and a portion of its cost may be assessed against the Stairs Creek dam, farther upstream, as it can also be used to transport materials for that site. By drawing down the head 70 feet 207,000 acre-feet of stored water would be obtained, which could be used through a head of 168 feet. If the period of drawdown were four months and if none of the storage sites above were developed, the net gain from the use of the stored water would be $16,000,000$ kilowatt-hours. 
The damage due to the development of this site would be the flooding of 400 acres of good agricultural land, of about 20 miles of trail, of the settlements of Agness and Illahe (see pl. 24, $A$ ), and of a few isolated shacks and farms. The amount to be paid for damages will be but a small proportion of the total cost of construction. The surface area of the pond created will be about 3,900 acres, most of which lies in the bottom of a narrow canyon or on the steep hillsides. The slack water of the pond will extend about 21 miles up the Rogue River and 13 miles up the Illinois River.

Potential power at undeveloped site 12RD 25

\begin{tabular}{|c|c|c|c|c|}
\hline & \multicolumn{2}{|c|}{ Flow (second-feet) } & \multicolumn{2}{|c|}{ Horsepower } \\
\hline & $\begin{array}{l}90 \text { per cent } \\
\text { of time }\end{array}$ & $\begin{array}{c}50 \text { per cent } \\
\text { of time }\end{array}$ & $\begin{array}{l}90 \text { per cent } \\
\text { of time }\end{array}$ & $\begin{array}{l}50 \text { per cent } \\
\text { of time }\end{array}$ \\
\hline $\begin{array}{l}\text { Natural flow } \\
\text { Regulated flow }\end{array}$ & $\begin{array}{l}1,220 \\
4,850\end{array}$ & $\begin{array}{l}5,150 \\
5,150\end{array}$ & $\begin{array}{l}19,500 \\
77,600\end{array}$ & $\begin{array}{l}82,400 \\
82,400\end{array}$ \\
\hline
\end{tabular}

SOUTH FORK POWRR SITE (12RD 27)

Water for the South Fork power project will be diverted from the South Fork of the Rogue River.just above the boundary of the Cascade National Forest, at an altitude of about 3,300 feet. Half a mile of conduit and a mile of tunnel will lead to a power-house site on the Middle Fork, where a head of 660 feet can be obtained. This head might be increased by diverting higher up on the South Fork, provided the discharge does not decrease rapidly upstream. Records of run-off on the South Fork near the proposed point of diversion are available for 1925 to 1928 . The water from this plant together with the flow of the Middle Fork would be carried by conduit to a point above the dam of the Prospect plant, the flow of Mill, Bar, and Red Blanket Creeks being diverted into the same conduit.

The natural Q90 flow at this site is about 65 second-feet and the Q50 flow 170 second-feet; 3,430 horsepower could be developed for 90 per cent of the time and 8,980 horsepower for 50 per cent of the time.

\section{RATCHERIA POWER SITE (12RD 28)}

By diverting the waters of Willow Creek and Rancheria Creek at the forks and carrying the water along the left bank of Butte Creek on the 2,540-foot contour to Butte Falls a head of 200 feet can be obtained. The flow available is practically the same as at the gaging station at Butte Falls. By constructing a canal along the same contour from the North Fork of Butte Creek to Butte Falls the flow would be increased by about 37 second-feet for 90 per cent of the time. This diversion from the North Fork would allow the water from that creek to be used for irrigation by the Eagle Irrigation District and for power in the plants proposed on its canals. About 5 miles of conduit of 120 second-feet capacity would be required from Rancheria Creek and about 2 miles of canal of about 50 second-feet capacity would be required from the North Fork of Butte Creek. A logging road follows Butte Creek above Butte Falls.

The natural Q90 flow at this site is 133 second-feet and the Q50 flow 160 second-feet; 2,130 horsepower could be developed for 90 per cent of the time and 2,560 horsepower for 50 per cent of the time.

$$
31558^{\circ}-32-7
$$




\section{MONEIL CREEK POWER SITE (12RD 30)}

The McNeil Creek power site is on the canal of the Eagle Point Irrigation District. A plant could be built at the MeNeil Creek siphon in the E. 1/2 sec. 36, T. 34 S., R. 1 E., to operate under a head of 330 feet; or by putting in a pressure pipe from the canal to Butte Creek in sec. 30, T. 34 S., R. 2 E., a head of 440 feet could be obtained. Both these sites could be operated only during the nonirrigation season. During the irrigation season the water could be used for power at two drops, one of 60 feet and one of 300 feet. The low flow on Butte Creek comes in August, September, and October, and this is also true of the Rogue River. The irrigation demand in these months is not very heavy, and it might pay to build the plant in sec. 30 on Butte Creek because of the extra 100 feet of head during the low-water season. This extra head would increase the minimum potential power by about 1,000 horsepower, provided the North Fork of Butte Creek is diverted into Butte Creek above the point of diversion of the Eagle Point Irrigation District. The canal for this purpose would be about 2 miles long and would increase the low flow by about 37 second-feet. With a head of 440 feet this would add 1,300 horsepower to the capacity of the site. The capacity of the site as given below is based on the assumption of three plants, one of 60 -foot head and one of 300 -foot head to be used during the irrigation season and one of 330 -foot head to be used during the nonirrigation season and to take the excess flow during the irrigation season.

The natural Q90 flow at this site is 133 second-feet and the.Q50 flow 160 secondfeet; 3,830 horsepower could be developed for 90 per cent of the time (head 360 feet) and 4,220 horsepower for 50 per cent of the time (head 330 feet).

\section{KERBY POWER SITE (12RD 34)}

A power plant is proposed to be located on the Illinois River just below the Kerby Dam, in sec. 29, T. 38 S., R. 8 W. The Kerby Reservoir and its alternative dam sites have been described on pages 64-65. (See fig. 11 and pls. 14, $A$, $15, A$, and $16, A$.) As it would be necessary for the turbines to operate under a variable head, this plant would not be as efficient as the others, but the assumed efficiency of 70 per cent would probably cover the loss of power due to the variation. It has been assumed that the dam would be located at the lower or Josephine Creek site. If the dam were built at the upper Kerby site the dam at Fall Creek would be raised 20 feet to use the additional head. The maximum power available at Kerby would be 22,000 horsepower, which would come in July, during the beginning of very low water. The head available would vary from 180 to 55 feet, with 5 feet fall between the tail water at Kerby and the head water from Fall Creek. The maximum altitude of the head water would be 1,360 feet, altitude of the tail water, 1,180 feet.

The potential power available at this site when operated primarily for storage for sites below, is as follows:

Potential power at undeveloped site 12RD 34

[Normal year]

\begin{tabular}{|c|c|c|c|c|}
\hline & \multicolumn{2}{|c|}{ Flow (second-feet) } & \multicolumn{2}{|c|}{ Horsepower } \\
\hline & $\begin{array}{l}90 \text { per cent } \\
\text { of time }\end{array}$ & $\begin{array}{c}50 \text { per cent } \\
\text { of time }\end{array}$ & $\begin{array}{l}90 \text { per cent } \\
\text { of time }\end{array}$ & $\begin{array}{l}50 \text { per cent } \\
\text { of time }\end{array}$ \\
\hline $\begin{array}{l}\text { Natural flow } \\
\text { Regulated flow }\end{array}$ & $\begin{array}{r}38 \\
0\end{array}$ & $\begin{array}{r}850 \\
1,070\end{array}$ & $\begin{array}{r}523 \\
0\end{array}$ & $\begin{array}{r}11,700 \\
6,500\end{array}$ \\
\hline
\end{tabular}




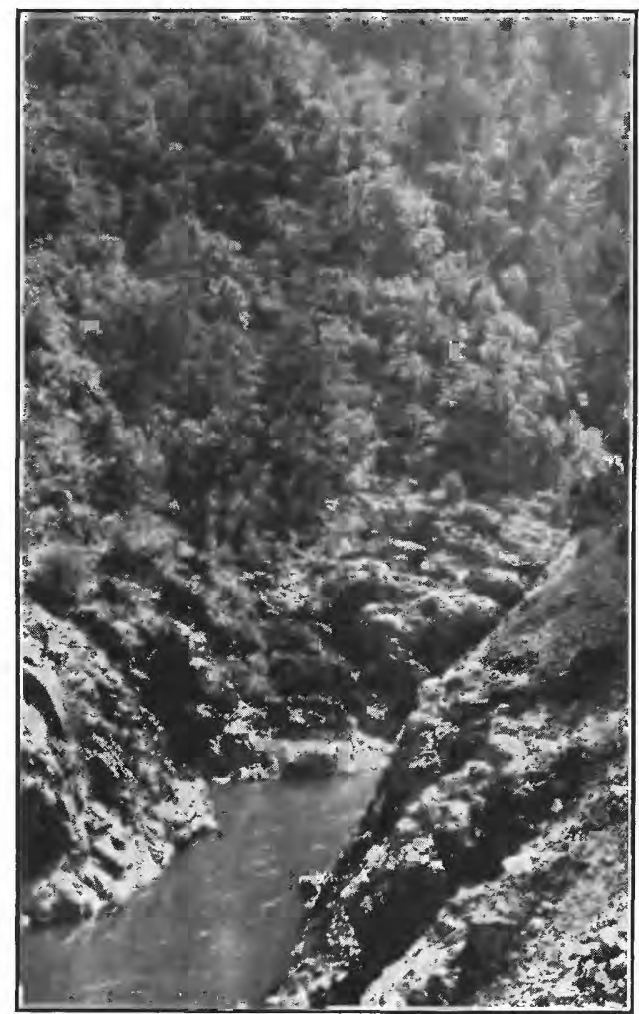

A. ROGUE RIVER BELOW THE MOUTH OF STAIRS CREEK

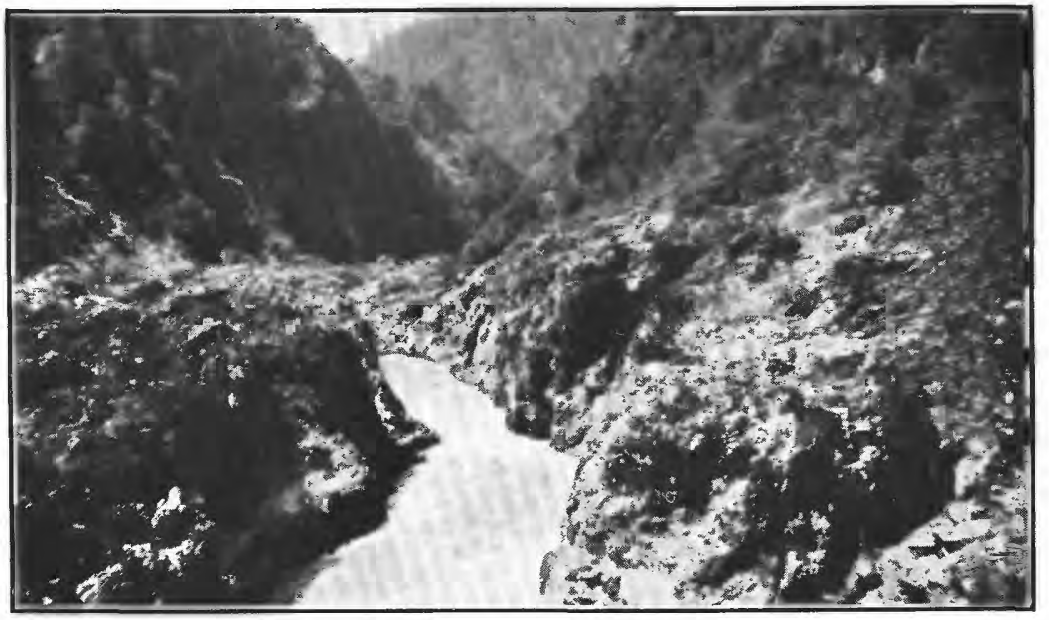

B. MULE CREEK CANYON, ROGUE RIVER, THREE-QUARTERS OF A MILE ABOVE STAIRS CREEK 


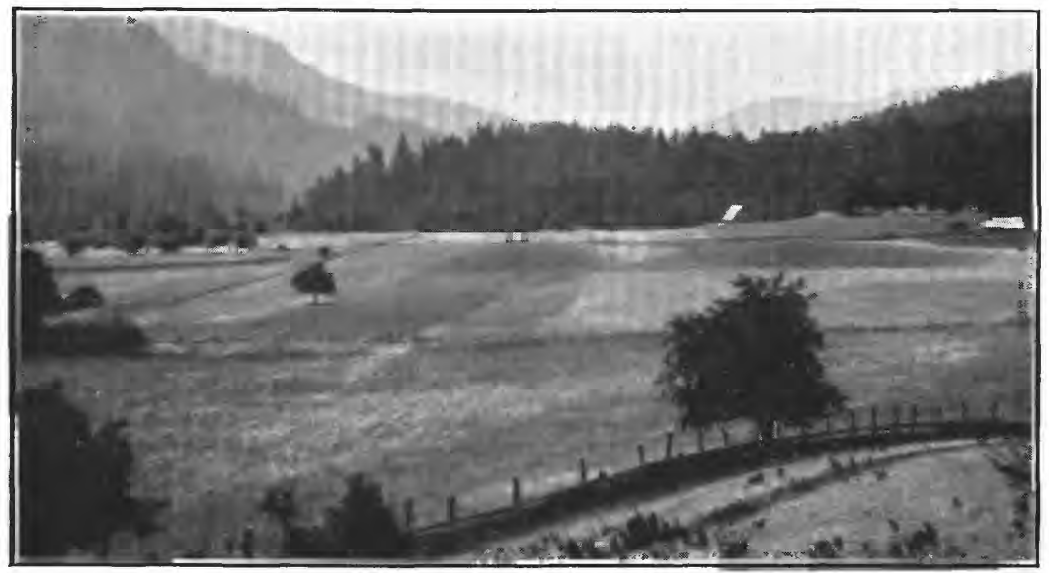

A. AGRICULTURAL LAND IN ROGUE RIVER VALLEY NEAR ILLAHE

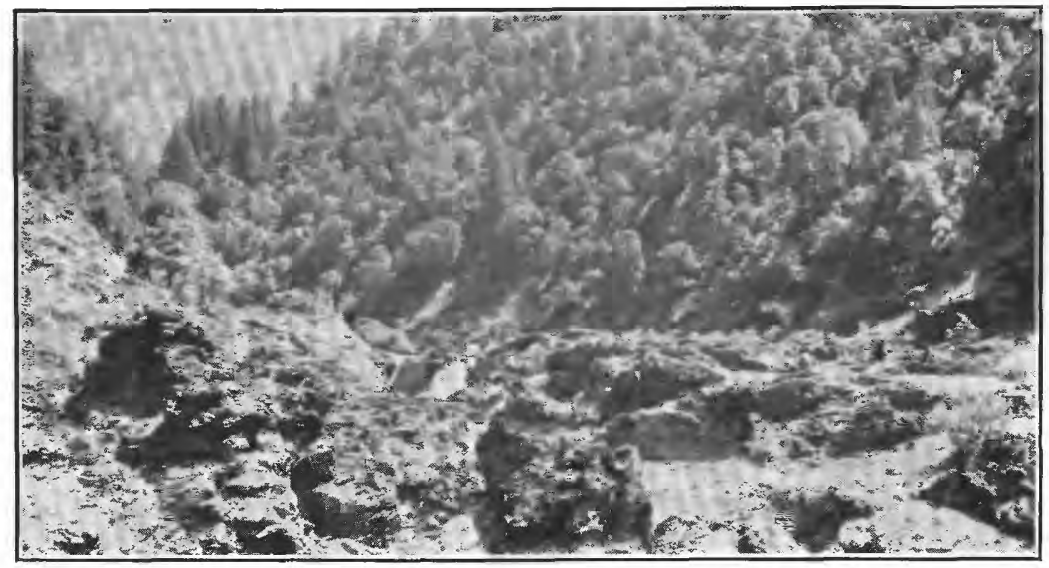

B. ILLINOIS RIVER AT FALL CREEK DAM SITE 


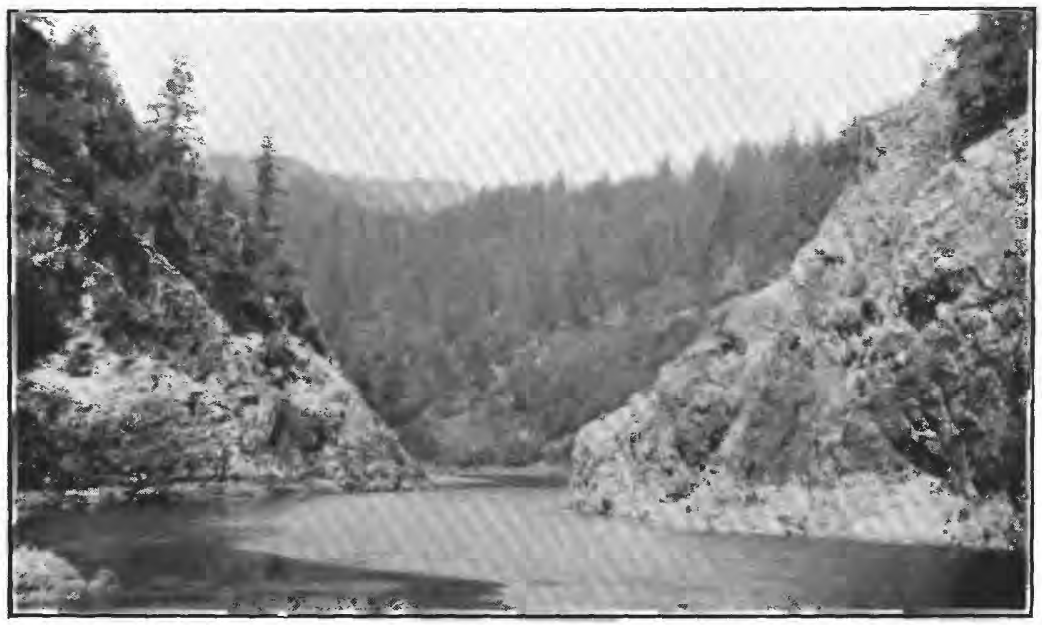

A. COPPER CANYON DAM SITE, ROGUE RIVER BASIN

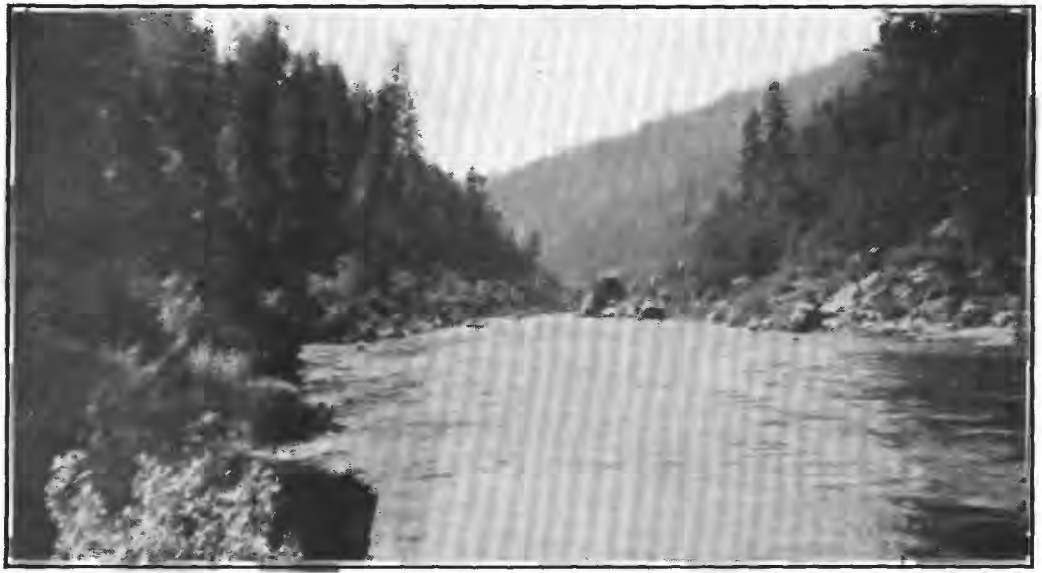

B. ROGUE RIVER FROM TROUT CREEK 


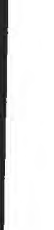

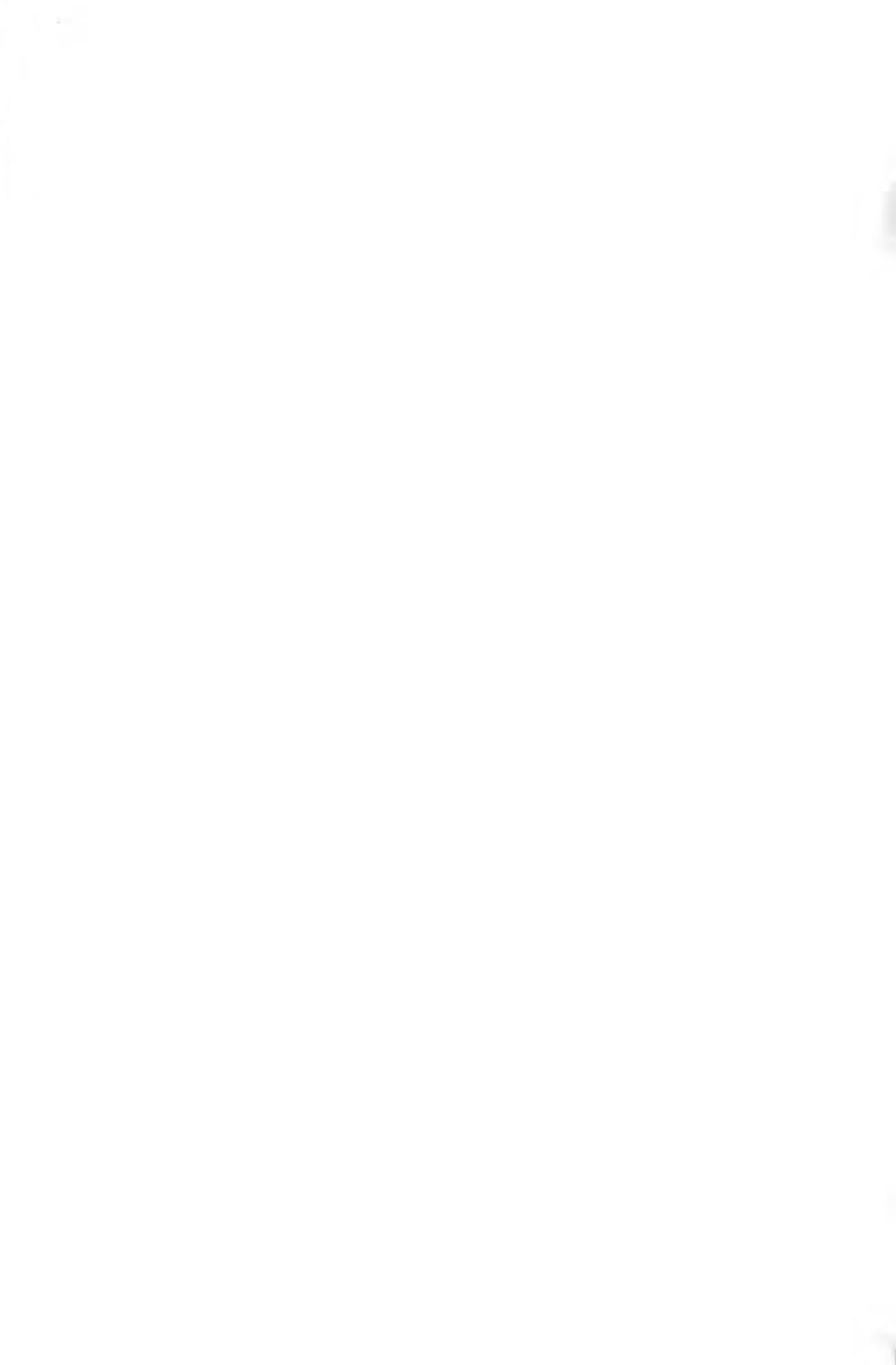

.

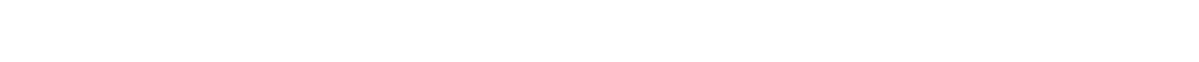

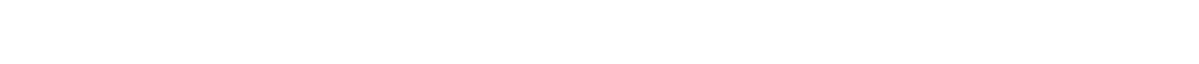

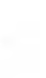
西

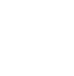
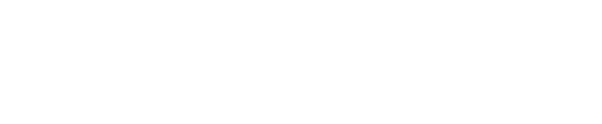

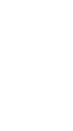

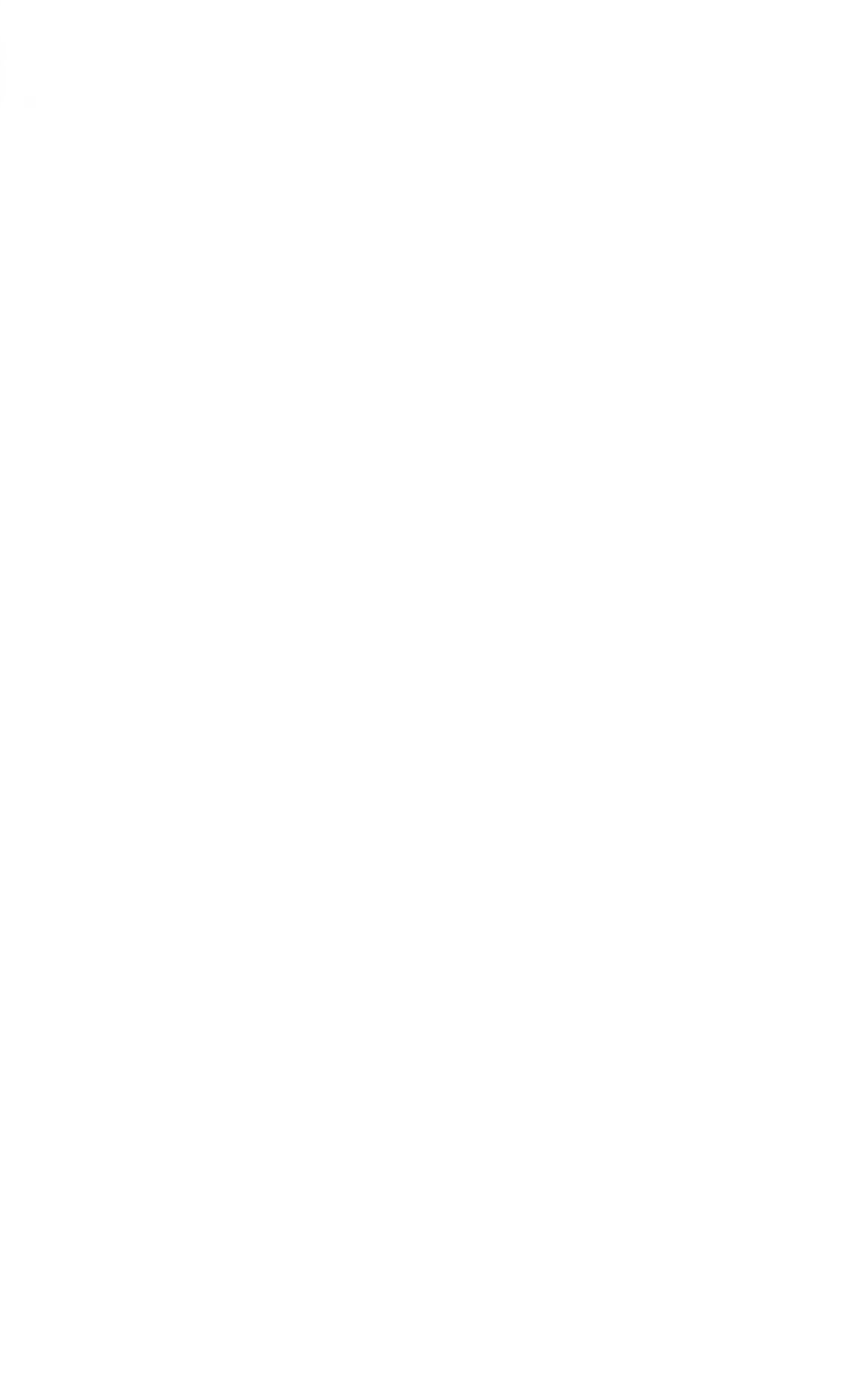


The above table would seem to indicate more power without than with regulation, but with regulation the period during which no power would be available would come during January, when the flow at Kerby would be entirely cut off and the entire load carried by plants below; on the other hand, with regulation the maximum amount of power would come during the low-water period, July to September, when the stored water would be released.
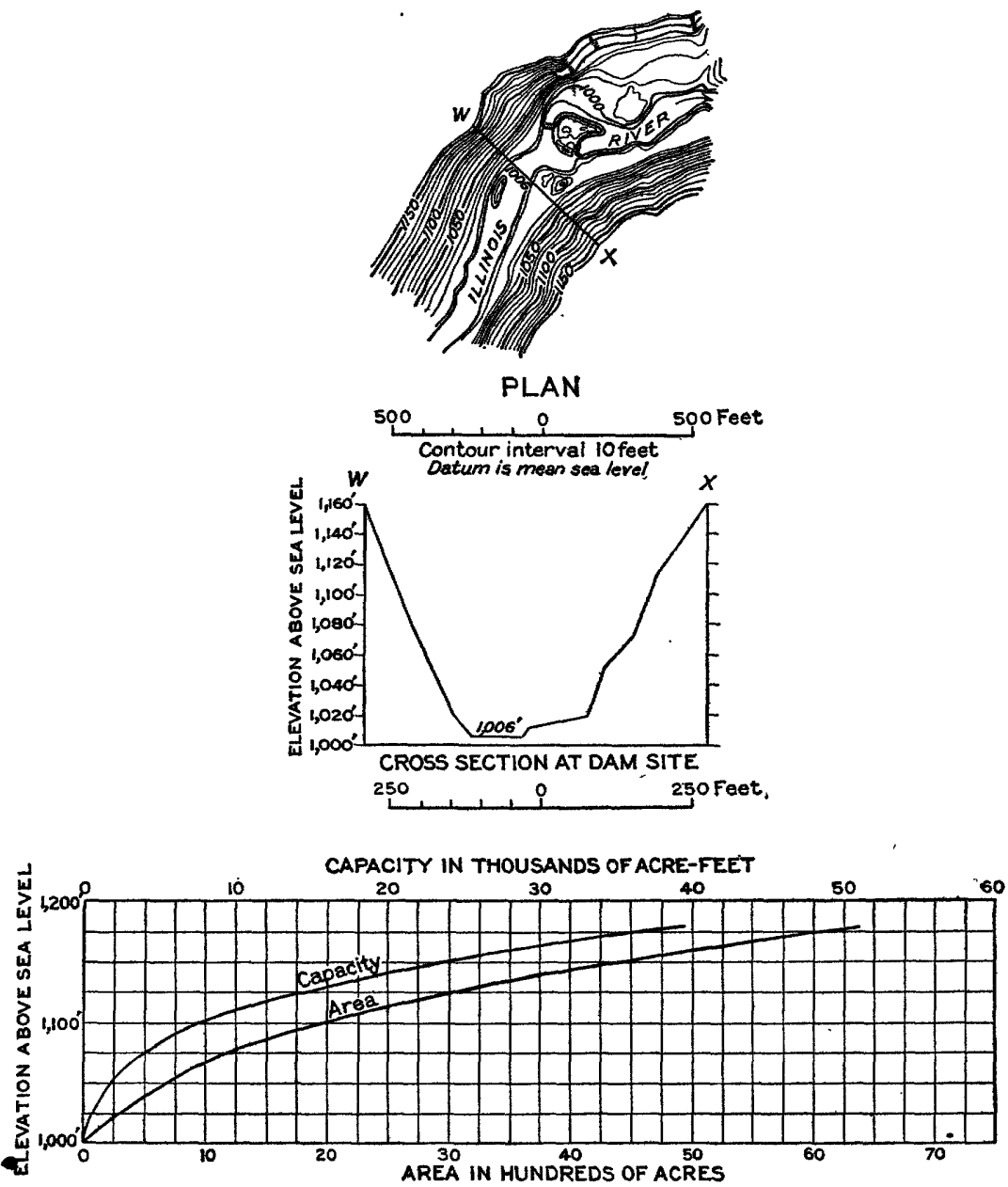

Figure 16.-Plan, cross section, and area and capacity curves, Fall Creek power site, Rogue River Basin

FALL CREEK POWER SITE (12RD 35)

The dam for the Fall Creek project would be located just above the falls at mile 39.7, in sec. 33, T. 37 S., R. 9 W. (See fig. 16 and pl. 24, B.)

In the vicinity of this site there is a complex of igneous and metamorphic rocks. The falls themselves seem to have resulted from differential erosion of diabase and serpentine. Upstream from the diabase there is a series of fine and coarse conglomerates greatly metamorphosed. The dark igneous rock that crops out at the dam site was determined by $C . S$. Ross to be a porphyritic andesite. In 
the conglomerate overlying this andesite there are cobbles of vesicular lava which suggest that the rock at the dam site is a surface flow and not an intrusive body. If so, it has been tilted and metamorphosed at the same time as the near-by conglomerates, and the whole mass has been changed into a compact, impermeable metamorphic series with only traces of the original character left. Joints are few. Bedrock occurs in the river bed and on both sides, so that no difficulties should be encountered in preventing seepage or in building the dam to the desired height.

The height proposed for the dam is $\mathbf{1 7 5}$ or 195 feet, depending on which dam site is used for the Kerby Reservoir. It has been assumed in calculating the storage and power capacity that a dam to raise the water surface 175 feet will be erected at Fall Creek. A tunnel 1.1 miles long with about 1,200 feet of pipe line would add 75 feet to the head, giving a total head of 250 feet. The dam would be a nonoverflow concrete structure with a spillway tunnel about 900 feet long across the bend. The altitude of head water would vary between 1,175 and 1,135 feet; altitude of tail water, 925 feet. With the assumed drawdown of 40 feet a storage capacity of 20,000 acre-feet would be made available. The power plant would be operated in connection with the other power plants on the river; the potential power is shown in the following table:

\section{Potential power at undeveloped site 12RD 35}

[Normal year]

\begin{tabular}{|c|c|c|c|c|}
\hline & \multicolumn{2}{|c|}{ Flow (second-feet) } & \multicolumn{2}{|c|}{ Horsepower } \\
\hline . & $\begin{array}{l}90 \text { per cent } \\
\text { of time }\end{array}$ & $\begin{array}{l}50 \text { per cent } \\
\text { of time }\end{array}$ & $\begin{array}{l}90 \text { per cent } \\
\text { of time }\end{array}$ & $\begin{array}{l}50 \text { per cent } \\
\text { of time }\end{array}$ \\
\hline $\begin{array}{l}\text { Natural flow } \\
\text { Regulated flow }\end{array}$ & $\begin{array}{r}60 \\
1,300\end{array}$ & $\begin{array}{l}1,330 \\
1,570\end{array}$ & $\begin{array}{r}1,200 \\
25,000\end{array}$ & $\begin{array}{l}26,600 \\
27,000\end{array}$ \\
\hline
\end{tabular}

Rock for concrete for the dam would be available near the site, and sand could be obtained by crushing. Cement would be hauled part way by railroad and the last 30 miles by truck. Damage from the construction of this plant would be negligible, as most of the land is public land.

\section{CLEAR CREEK POWER SITE (12RD 36)}

The dam for the Clear Creek project would be built above the mouth of the creek at mile 30 , which when the area is surveyed will probably be found to be in sec. 2, T. 37 S., R. $10 \mathrm{~W}$. The site is in the rugged canyon of the Illinois River, which is carved out of ancient intrusive rocks. There are excellent exposures of rock on both sides of the river, and a specimen examined by C. S. Ross was determined to be very fresh diorite. It is a dark-blue rock resembling granite in fts crystalline character and will afford an ideal foundation because of its great strength and impermeability. No difficulty should be experienced in building a dam of the desired height.

The height proposed is 190 feet, which would back the water to a point within 5 feet of the level of tail-water at the Fall Creek site. Half a mile of tunnel would add 30 feet to the head, the power house being located at mile 28.8. An additional 20 feet of head would be added by half a mile of pipe line, or this head could be developed by adding 20 feet to the height of the dam at Bald Mountain. This additional height of 20 feet at Bald Mountain would afford 8,900 acre-feet of pondage, which probably would be of considerable advantage, and it has therefore been assumed that this head will be developed at Bald Mountain. The total 
head at the Clear Creek site would be 220 feet. The altitude of head water at this site would vary between 920 and 880 feet and the altitude of tail water would be 700 feet. The storage capacity for 40 -foot drawdown would be 16,500 acre-feet. The estimated flow at this site for a normal year is given in Table 10. The potential power when this site is operated in connection with other plants on the river would be as shown in the following table:

Potential power at undeveloped site 12RD 36

[Normal year]

\begin{tabular}{l|r|r|r|r}
\hline & Flow (second-feet) & \multicolumn{2}{|c|}{ Horsepower } \\
\hline & $\begin{array}{r}90 \text { per cent } \\
\text { of time }\end{array}$ & $\begin{array}{r}50 \text { per cent } \\
\text { of time }\end{array}$ & $\begin{array}{c}90 \text { per cent } \\
\text { of time }\end{array}$ & $\begin{array}{c}50 \text { per cent } \\
\text { of time }\end{array}$ \\
\hline Natural flow & $\begin{array}{r}80 \\
\text { Regulated flow }\end{array}$ & $\mathbf{1 , 8 0 0}$ & $\mathbf{1 , 4 0 0}$ & 31,700 \\
\hline
\end{tabular}

It would be necessary to build about 10 miles of highway or 40 miles of railroad to reach this site, which is 10 miles below Fall Creek. The only construction material available at the site is rock which could be crushed to furnish sand. The lands that would be flooded by this project are on steep hillsides, practically all publicly owned.

\section{BAID MOUNTAIN POWER SITE (12RD 37)}

The dam for the Bald Mountain project would be located at mile 21.2, at an altitude of $\mathbf{5 2 5}$ feet, where the river starts its bend around Bald Mountain. When the land is surveyed this site will probably be in sec. 26, T. 36 S., R. $11 \mathrm{~W}$.

The geology of this site was not studied because of the difficulty of reaching it, but a traverse made along the trail to Agness indicates that the site is probably satisfactory. About 5 miles upstream from the site the trail turns away from the river and makes a steep ascent to the top of Bald Mountain. The first outcrops of sandstone observed in the entire traverse made from the Falls Creek site were along the trail, about 2,500 feet above the river. The sandstone is altered, almost to a quartzite. Near the top of Bald Mountain there are a couple of small seeps, the water being brought to the surface by some shale beds that underlie the sandstone. From the top of the mountain the trail goes down a steep canyon wall by means of switchbacks. Along this trail were found chips of sandstone, and at Silver Creek a diabase dike is intruded into conglomerate, probably of Cretaceous age. Thus in the entire traverse nothing was found to suggest that the structure of the Bald Mountain dam site was anything but good.

The canyon of the river is narrow, and a small amount of surface stripping would probably expose good rock foundations. An overflow dam 170 feet high is proposed. This would back water within 5 feet of tail water of the Clear Creek plant. A tunnel 2.8 miles long under Bald Mountain would add an additicnal head of 255 feet, if the fall below an altitude of 270 feet were utilized in a plant at Copper Canyon, on the Rogue River. An additional head of 65 feet can be obtained with about the same length of tunnel provided the Copper Canyon dam is built to a lower height.

The head between the proposed Bald Mountain site and the backwater from the Copper Canyon site on the Rogue River could be developed by dams instead of by a tunnel, and a dam site was surveyed at mile 12.3, a short distance below Collier Creek. (See fig. 17.) This site may be taken as typical of this part of the Illinois River, as there are many good sites between it and the Bald Mountain site. An example of the use of a tunnel rather than a dam is afforded by a con- 
structed plant in Georgia, where a tunnel 5,600 feet long was built to obtain a head of 100 feet. On the basis of the head per mile obtained by this tunnel, the tunnel under Bald Mountain could be 2.8 miles long if the Copper Canyon dam is built to the full height. The average continuous output at this constructed plant is less than 5,000 horsepower, compared with an average estimated output at the Bald Mountain site of 14,000 horsepower for each 100 feet of head.

No agricultural land would be flooded by this project, and practically the whole area is publicly owned. Head water at this site would fluctuate between an altitude of 695 and 655 feet, and the tail water would be at 270 feet. The storage capacity afforded by a drawdown of 40 feet would be 15,000 acre-feet.

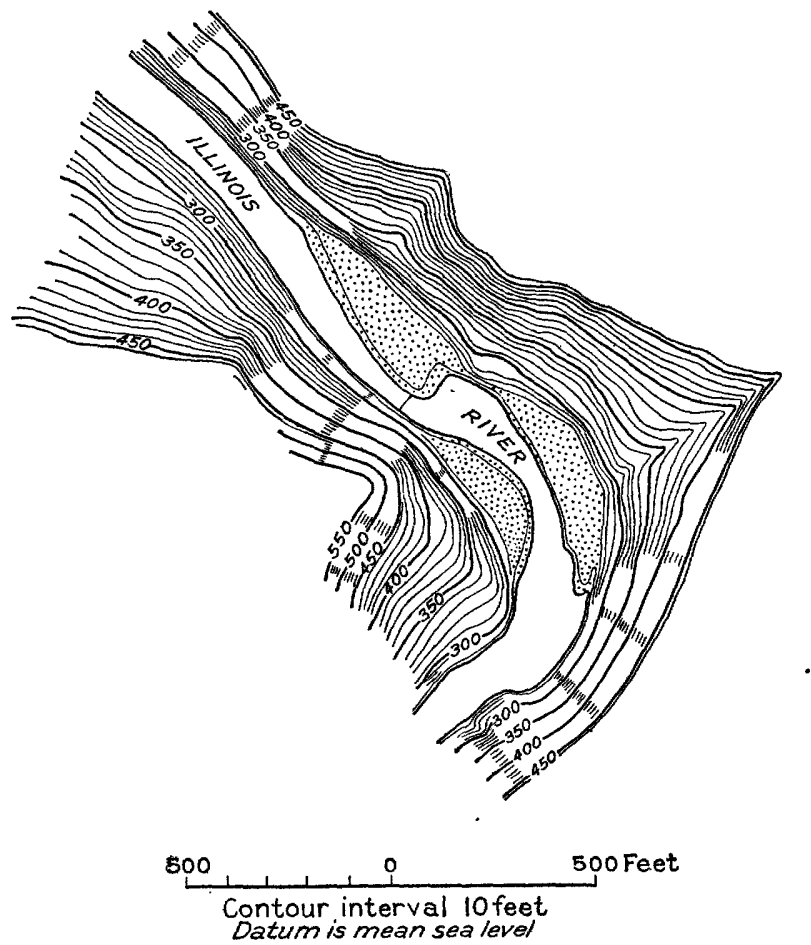

Figure 17. -Plan, Collier Bar dam site, Rogue River Basin

In calculating the power at Bald Mountain it is assumed that the Copper Canyon dam would be built to the full height, or to an altitude of 270 feet.

Potential power at undeveloped site 12RD 97

[Normal year]

\begin{tabular}{|c|c|c|c|c|}
\hline & \multicolumn{2}{|c|}{ Flow (second-feet) } & \multicolumn{2}{|c|}{ Horsepower } \\
\hline & $\begin{array}{l}90 \text { per cent } \\
\text { of time }\end{array}$ & $\begin{array}{l}50 \text { per cent } \\
\text { of time }\end{array}$ & $\begin{array}{l}90 \text { per cent } \\
\text { of time }\end{array}$ & $\begin{array}{l}50 \text { per cent } \\
\text { of time }\end{array}$ \\
\hline $\begin{array}{l}\text { Natural flow } \\
\text { Regulated flow }\end{array}$ & $\begin{array}{r}85 \\
1,770\end{array}$ & $\begin{array}{l}1,910 \\
2,290\end{array}$ & $\begin{array}{r}2,900 \\
60,300\end{array}$ & $\begin{array}{l}65,000 \\
78,00 ?\end{array}$ \\
\hline
\end{tabular}




\section{MARKET}

The location of each of the developed and undeveloped power sites in the Rogue River Basin is shown on the general map of the area (pl. 3) and the small-scale profile (pl. 4).

By constructing a trunk transmission line along the river all the sites can readily be linked into one unified system. The power output of this system will be so large that only a very small percentage of it can be absorbed in the immediate vicinity unless industries requiring large blocks of power locate near by. The electrification of the railroads in the basin would provide an outlet for a considerable block of power, but this would be only a small part of the power that can be obtained. Sites on the Illinois River and the lower Rogue River are close to the coast, where raw material could be brought by water. As an example, bauxite for the production of aluminum could readily be brought from South America to some port near the mouth of the Rogue River for treatment. This industry and other electrometallurgical processes requiring cheap power may soon be forced to the Pacific Northwest for a location. Such industries offer probably a more immediate market for the power available on the Rogue River than the public utilities of Portland or San Francisco, but if the power is not developed for industrial use in the vicinity there seems little question that it will be developed for public utilities in the not very distant future.

The power consumption of the United States doubles every eight or ten years. In the period from 1921 to 1928 the developed water power in California increased from $1,149,000$ to $2,227,000$ horsepower and in Oregon from 185,000 to 289,000 horsepower. Already most of the cheaper water-power sites in California are developed. It is conceivable, therefore, that power from sites on the Rogue River can be sold in California before many years elapse. San Francisco is 350 miles distant. Power from the Rogue River could be used in northern California, releasing power from plants in that region for use in San Francisco. Portland and cities in the Willamette Valley also will require more power, but there are large sites on the Columbia River that can be developed to supply this market, and these will compete with sites on the Rogue River as economical sources of power for metallurgical and similar industries. At present the most probable use for power from the Rogue River is in some manufacturing process requiring large amounts of cheap power or for public utilities in northern California. 



\title{
OUTLINE OF METHODS FOR ESTIMATING GROUND-WATER SUPPLIES $^{1}$
}

\author{
By Oscar Edward Meinzer
}

\section{INTRODUCTION}

The most urgent problems in ground-water hydrology at present are those relating to the rate at which the rock formations will supply water to wells in specified areas-not during a day, a month, or a year but perennially. The permeable rock formations may be regarded as underground reservoirs or as underground conduits. Some waterbearing formations function chiefly as reservoirs, others chiefly as conduits, but all of them have some of the properties. of both. In attempting to solve the quantitative problems above mentioned these two functions of rock formations must be recognized and differentiated. Quantitative methods based on the reservoir conception are applicable chiefly, though not exclusively, to formations or parts of formations that have water tables; methods based on the conduit conception are applicable most largely to artesian formations, in which the water moves laterally considerable distances from the intake to the discharge area.

\section{ROCK FORMATIONS AS RESERVOIRS}

\section{GENERAL CONDITIONS}

The natural reservoirs formed by rock formations generally have very great capacity compared with that of ordinary artificial surface reservoirs, just as most other natural features are of huge size in contrast to the works of man. However, if the water derived from them is taken chiefly out of storage without being replaced the supply will eventually fail.

The "safe yield" of an underground reservoir, or the practicable rate of withdrawing water from it perennially for human use, may be estimated by methods that are comparable to those used in estimating the safe yield of a surface reservoir, although different in

1 The substance of this paper was presented Dec. 29,1928 , at a meeting of the Society of Economic Geologists in New York City, and mimeographed copies of the paper in abbreviated form had been sent to the members prior to the meeting. The paper has been revised and enlarged for the present publication. 
technique. It is necessary to measure the rate of inflow (intake methods) or the rate of discharge (discharge methods), or else these rates must be estimated by determining changes in storage (watertable or storage methods)..$^{2}$ In many areas the most effective method of studying the ground-water supply is the inventory method, in which all available methods are used to make periodic inventories of the entire water supply of the area, from its entrance into the area as precipitation, stream flow, or underground percolation to its exit as evaporation, transpiration, run-off, or underground leakage.

The work of Charles H. Lee ${ }^{3}$ in Owens Valley, Calif., in 1908 to 1911 , is of outstanding importance in the history of quantitative methods in ground-water work, because he devised an entire system of quantitative methods and applied them in orderly fashion to obtain an average value for each element of intake into and discharge out of the underground reservoir. The term "inventory method" is more accurately applied, however, to investigations in which a detailed accounting of the several elements of intake, storage, and discharge is attempted for each of successive months, years, or other units of time during the entire period of observations. Thus, in the investigation in the Pomperaug Basin, Conn., ${ }^{4}$ an attempt was made to organize the available data in a monthly. inventory of the water supply during a period of three years.

\section{METHODS FOR ESTIMATING INTAKE FROM SURFACE STREAMS}

The principal intake method consists of establishing gaging stations on influent streams and determining the quantities of water lost between successive stations. The quantity of water that reaches the water table consists of this loss minus the loss by evaporation and transpiration either directly from the stream or from soil moisture supplied by the stream. The method has been used in many ground-water investigations in the present century, notably in California, Arizona, New Mexico, Nevada, Utah, Colorado, and Idaho. The earliest measurements of seepage losses from streams and canals were made chiefly to ascertain the losses of surface waterfor example, the investigation by Grunsky, ${ }^{5}$ in 1882, of losses from

\footnotetext{
${ }^{2}$ Meinzer, o. E., Quantitative methods of estimating ground-water supplies: Geol. Soc. America Bull., vol. 31, pp. 329-338, 1920.

${ }^{3}$ Lee, C. H., An intensive study of the water resources of a part of Owens Valley, Calif.: U. S. Geol. Survey Water-Supply Paper 294, 1912; The determination of safe yield of underground reservoirs of the closed-basin type: Am. Soc. Civil Eng. Trans., vol. 78 , pp. 148-251, 1915.

4 Meinzer, O. E., and Stearns, N. D., A study of ground water in the Pomperaug Basin, Conn., with special reference to intake and discharge: U. S. Geol. Survey Water-Supply Paper 597, pp. 73-146, 1928.

${ }^{\mathrm{s}}$ Grunsky, C. E., Irrigation near Fresno, Calif. : U. S. Geol. Survey Water-Supply Paper 18, pp. 71-79, 1898.
} 
irrigation canals in the vicinity of Fresno, Calif. Later, however, in several investigations, seepage losses have been determined chiefly for the purpose of estimating the amount of ground-water recharge. Notable among the early ground-water investigations in which the seepage method was used are those of Clapp ${ }^{\circ}$ and Mendenhall ${ }^{7}$ in southern California, Smith in Arizona, ${ }^{8}$ and Lee in Owens Valley. One of the most intensive studies of this method was made by Bailey ${ }^{\circ}$ in his work on ground-water recharge in the Niles cone, California, by seepage from Alameda Creek. Bailey undertook not only to determine the recharge by years or other long periods, but also to determine the daily recharge, which required accurate data on changes in channel storage with changes in gage heights. $\mathrm{He}$ also investigated the relation of rate of recharge to the temperature of the water and to the duration of high stages of the river. Uitimately he developed curves to show the relation of rate of seepage to rate of stream flow and produced an empirical formula by which the recharge in any day can be computed from the records of stream flow and temperature. Intensive use of the seepage method has recently been made by Conkling ${ }^{10}$ in the drainage basin of the San Gabriel River, and by Post ${ }^{11}$ in the drainage basin of the Santa Ana River, both in California.

The seepage method gives the most reliable results for streams with relatively constant flow and heavy losses in proportion to the total flow. It is generally not applicable in times of flood, when the measurements of flow are relatively inaccurate and the percentage of loss is small. It is not applicable or only difficultly applicable to perennial streams in which the loss is small in comparison to the total flow, because with such streams small percentage errors in the measurements of the flow may produce large percentage errors in the computed seepage losses.

The seepage method is not very applicable for determining recharge from intermittent and ephemeral streams and is wholly inapplicable for determining recharge directly from rain or melting

${ }^{6}$ Clapp, W. B., in Hoyt, J. C., Report of progress of stream measurements for the calendar year 1903, pt. 4, Interior Basin, Pacific, and Hudson Bay drainage: U. S. Geol. Survey Water-Supply Paper 100, pp. 339-356, 1904.

${ }^{7}$ Mendenhall, W. C., The hydrology of San Bernardino Valley, Calif.: U. S. Geol. Survey Water-Supply Paper 142, pp. 50, 51, 1905; Ground waters and irrigation enterprises in the foothill belt, southern California: U. S. Geol. Survey Water-Suppiy Paper 219 , pp. 28, 29, 1908 .

${ }^{8}$ Smith, G. E. P., Ground-water supply and irrigation in the Rillito Valley : Arizona Univ. Agr. Exper. Sta. Bull. 64, pp. 118, 119, Tucson, 1910.

- Bailey, Paul, Engineering investigation of percolation from Alameda Creek and groundwater studies on Niles cone: Callfornia State Water Comm. Third Bienn. Rept., pp. 95131, 1921.

to Conkling, Harold, San Gabriel investigation: California Dept. Pub. Works Div. Water Rights Bull. 5, pp. 52-72, 1927.

11 Post, W. S., Santa Ana investigation, flood control and conservation: Callornia, Dept. Pub. Works Div. Eng. and Irr. Bull. 19, pp. 165-179, 1920. 
snow. In humid regions almost no streams except the ephemeral ones are influent, and therefore this method obviously has little application. The method as applied to ephemeral streams presents two difficulties-the storm run-off is too flashy to be measured accurately, and a considerable part of the surface water lost by seepage may be held by molecular attraction in the soil and subsoil and therefore may not reach the water table but may ultimately be returned to the atmosphere.

Studies have recently been made by White ${ }^{12}$ of recharge from the flow of the Mimbres River, an intermittent stream in New Mexico, which generally flows about 20 to 36 hours after a torrential summer rain. The flow from some of the rainstorms was all lost within the stretch of the river that crosses the intake area, and the loss could be determined by measuring the flow at the upper end of this stretch. In the heaviest storms, however, the flow persisted beyond the intake area, and measurements were made at convenient intervals within this stretch to determine the approximate loss. Borings were made in the bed of the river before and after the storms, and the moisture content of samples obtained from these borings was determined in order to ascertain how much of the seepage water was held by the sand of the river bed.

\section{METHODS FOR ESTIMATING INTAKE DIRECTLY FROM RAIN AND MELTING SNOW}

Many attempts have been made to measure directly the percolation from the surface to the water table. Mariotte, in the seventeenth century, observed the percolation of rain water into the cellar of the Paris Observatory. Measurements of percolation have been made with lysimeters, or vessels to catch the downward percolating water, by several European ${ }^{13}$ and American ${ }^{14}$ investigators, and some very long records have been obtained in England. The first tests mentioned by Veatch were made by Dalton in Manchester, England, from 1796 to 1798 , and by Maurice in Geneva, Switzerland, in 1796 and 1797. The longest record, that of Dickinson and Evans, in Hempel Hempstead, in England, extended over at least 49 years, from 1835 to 1884, and the records of Lawes and Gilbert and those of Greaves extended over 32 and 22 years, respectively. Many of

12 White, W. N., Preliminary report on the ground-water supply of Mimbres Valley, N. Mex. : U. S. Geol. Survey Water-Supply Paper 637, pp. 77-80, 1931. (Released in manuscript form in 1929.)

${ }^{13}$ Veatch, A. C., Fluctuations of the water level in wells: U. S. Geol. Survey WaterSupply Paper 155, pp. 32-34, 44-49, 1906. This paper summarizes the work that had been done with lysimeters in England and on the continent of Europe.

14 Bark, D. H., Duty of water investigations, experiments, and results: Idaho State Engineer Ninth Bienn. Rept. (1911-12), pp. 302-309; Experiments on the economical use of irrigation water in Idaho: U. S. Dept. Agr. Bull. 339, pp. 37-39, 1916 . Other American experiments could be cited. 
the lysimeter tests have been made with disturbed materials and under other artificial conditions, which may have produced results very different from those that would be found under natural conditions. Moreover, even if tests are made under natural conditions, the fundamental difficulty will still be encountered that downward percolation is irregularly distributed, and it is difficult or impossible to find a place for the test that is even approximately representative of average conditions. An extensive area may have little or no recharge, but at a few places water may be pouring into the zone of saturation in large volumes.

Tests recently made by H. F. Blaney and C. A. Taylor ${ }^{15}$ near Ontario, Calif., indicate that water percolating downward through unsaturated material tends to follow the surface of the constituent grains and hence to move around any vessel that is placed underground to catch it. If the material extends downward into the vessel, the percolating water will accumulate in the capillary openings of the material in the vessel and can be detected by laboratory determination of the increase in moisture content of that material. However, unless the material lies within the vessel to a height exceeding the capillary range, no free gravity water may appear in the vessel even though recharge is occurring.

The earliest attempts to determine the rate of ground-water recharge were doubtless based on measurements of the quantities of water that fall as rain or snow. This was the method of Mariotte, ${ }^{16}$ who attempted a quantitative study of the water supply of the drainage basin of the Seine River by making crude measurements of the water that fell as rain on the basin and of the water discharged by the river. By means of these measurements he disproved the ancient assumption that the rainfall is inadequate in amount to supply the water discharged by the springs. In the years that have elapsed since Mariotte's work the most common method of estimating ground-water recharge has probably been to determine approximately the quantity of water that annually falls as rain or snow on a given area and apply to this quantity the percentage that is assumed to reach the zone of saturation. This method is of little value, however, except to give an idea of the maximum possibilities, unless there is a reliable basis for the percentage that is assumed. Commonly the assumed percentage and therefore also the computed recharge are much too large.

\footnotetext{
15 Unpublished data. Since this paper was sent to press the following paper describing these methods has been published: Taylor, G. H., Investigations relating to the absorption of precipitation and its penetration to the zone of saturation: Am. Geophysical Union Trans. 12th meeting, pp. 206-211, 1931.

10 Mariotte, Edmé, Traités du mouvements des eaux et des autres corps fluides, 1686.
} 
Attempts have been made to compute the recharge in an intake area by deducting the run-off and the evaporation (including transpiration) from the precipitation, but the results have generally been unreliable, especially because of uncertainty as to the amount of evaporation and transpiration. The method is inapplicable where the recharge is relatively so small that a moderate percentage error in precipitation, run-off, or evaporation may produce a large percentage error in the computed reeharge. It apparently gave useful results as applied by $\mathrm{McCombs}{ }^{17}$ and Kunesh ${ }^{18}$ in estimating the ground-water supply of the island of Oahu, where fairly accurate data are available as to precipitation and run-off and where the intake facilities are so good that a large proportion of the precipitation seeps into the rocks and percolates to the water table. The weakest element in the Oahu computations was the estimate of evaporation, for which reliable data.were not available. To overcome this weakness, tests of soil evaporation and transpiration are now being made.

Recently a detailed study has been made with this method by Blaney ${ }^{19}$ in certain intake areas in southern California. From the quantity of water produced by each rain during the winter rainy season were deducted the carefully estimated quantities of run-off produced by the rain and of soil evaporation and transpiration during the subsequent period of fair weather. Borings and tests of soil moisture proved that the remaining water was stored in the soil to satisfy the deficiency of soil moisture in the root zone. After this deficiency had been completely supplied and the soil moisture had been brought up to the specific retention, or quantity of water that the soil can hold by molecular attraction against the pull of gravity, any remaining surplus was assumed to percolate downward beyond the reach of plant roots and ultimately to reach the water table. If an impermeable bed intervened between the root zone and the water table, the downward percolating water would necessarily form a body of perched ground water above the impermeable bed.

The method of following the movements of water in the soil by making periodic borings with soil augers and determining the moisture content of soil samples obtained from different depths has been extensively used in connection with agricultural investigations and less frequently to determine the ground-water recharge. Re-

17 McCombs, John, Methods of estimating safe yield of Honolulu artesian area : Honolulu Sewer and Water Comm. Rept., 1927, pp. 55-61.

18 Kunesh, J. F., Surface, spring, and tunnel water investigations: Honolulu Sewer and Water Comm. Rept., 1929, pp. 85-92.

10 Blaney, H. F., Disposal of rainfall, in Post, W. S., op. cit. (Santa Ana investigation), pp. 152-157. 
cently, however, earnest attempts have been made to use this method in ground-water investigations in California by Sonderegger,${ }^{20}$ by Blaney and C. A. Taylor, and by Stearns, Robinson, and G. H. Taylor. ${ }^{21}$ In the latest work by G. H. Taylor the moisture equivalent, or amount of moisture retained by the soil in a centrifuge, was taken as a rough measure of the specific retention in computing deficiencies in the belt of soil moisture, or " root zone."

\section{METHODS FOR ESTIMATING DISCHARGE BY OVERFLOW}

An underground reservoir, like a surface reservoir, may lose water by overflow, evaporation, diversion, and underground leakage. The overflow of an underground reservoir may appear in definite springs or in general seepage that contributes to the flow of the surface streams. If it appears in a few large and definite springs the ground-water discharge can be determined by measuring the flow of these springs. If the springs are relatively constant it may be sufficient to make occasional measurements with current meter, weir, or other device; if they are relatively variable it may be necessary to establish gaging stations in order to obtain records of daily or continuous rate of flow. An excellent example of an extensive survey made largely by the first method is that by Crandall ${ }^{22}$ and others of the very large and relatively constant springs that issue from the lava rocks into the Snake River, in Idaho. Examples of the second method are afforded by gaging stations, some of them with automatic water-stage recorders, maintained by the United States Geological Survey on several of the springs of first magnitude in Missouri and Texas that issue from limestone and have great fluctuations. ${ }^{23}$

If the overflow of the underground reservoir appears in many small, widely scattered springs or in general seepage its quantity may be estimated by establishing gaging stations on the effluent streams to measure the total run-off and then differentiating between the two components of the total-the direct run-off and the groundwater run-off. This differentiation can best be made by studying

\footnotetext{
20 Sonderegger, A. L., Water supply from rainfall on valley floors: Am. Soc. Civil Eng. Proc., vol. 55, pp. 1144-1150, 1929. Since this paper was sent to press-the following paper relating to this subject has been published: Blaney, H. F., Taylor, C. A., and Young, A. A., Rainfall penetration and consumptive use of water in Santa Ana River valley and coastal plain : California Div. Water Resources Bull. 33, 1931.

21 Stearns, H. T., Robinson, T. W., and Taylor, G. H., Geology and water resources 'of the Mokelumne area, California: U. S. Geol. Survey Water-Supply Paper 619, pp. 174, 175, 1930 ; also more recent report released in manuscript form (on flle in public library, Lodi, Caltf.).

\& Crandall, Lynn, The springs of Snake River Canyon: Idaho Irr. Eng. and Agr. Societies Joint Conf., 1918 and 1919, Proc., pp. 146-150. See also Meinzer, O. E., Large springs in the United States: U. S. Geol. Survey Water-Supply Paper 557, pp. 42-47, 1927. 23 Meinzer, O. E., op. cit., pp. 17-41.
} 
small representative drainage basins rather than by gaging the trunk stream of a large drainage basin, because the large basin is likely to have more frequent rainfall in some parts of its area and a longer and less definite period for complete delivery of the direct run-off.

In a study by the United States Geological Survey of the drainage basin of the Pomperaug River, in Connecticut, which has an area of 89 square miles, a gaging station was established near the mouth of the river. It was determined, from considerations of channel storage, velocity of the water, and rate of movement of flood crests, that the direct run-off is nearly all delivered from the basin within a week of the time the water falls as rain, and that therefore the stream flow a week or more after the latest rain is virtually all derived from ground water. A hydrograph was constructed of the total run-off for the years covered by the investigation, 1913 to 1916 . and a hydrograph of the ground-water run-off was then made which coincided with that for total run-off in the periods of prolonged fair weather and was interpolated between these periods. The groundwater run-off was computed from this hydrograph. ${ }^{24}$ This general method was earlier used in the flood-control investigation of the drainage basin of the Miami River, in Ohio, by Houk, ${ }^{25}$ who prepared a hydrograph of the ground-water run-off of the Mad River for the period 1915 to 1919 by connecting the low points of the hydrograph for total run-off.

The method can be improved by obtaining gage-height records at enough points in the drainage system to permit an estimate of the channel storage of the system on each day. The daily ground-water run-off can then be computed as soon after a rain as the storm water has reached the streams. For any day with a falling stage after the storm water has reached the streams, the ground-water run-off will be the total run-off minus the decrease in channel storage. The decrease in channel storage can be estimated by maintaining gages at several points on the trunk stream and on selected tributaries and making surveys of the stream system showing the approximate water areas of different parts of the system at different gage heights. Calculations show that in a drainage basin which is not larger than the Pomperaug the total quantity of water stored in the stream system at any time is rather small compared with the rate of discharge, and hence that errors in the measurement of decrease in storage will introduce relatively small errors in the estimates of ground-water run-off. The proposed method would have the advantage that the

\footnotetext{
24 Meinzer, O. E., and Stearns, N. D., A study of ground water in the Pomperaug Basin, Conn., with special reference to intake and discharge: U. S. Geol. Survey Water-Supply Paper 597, pp. 107-116, pl. 19, 1929.

${ }_{25}$ Houk, I. E., Rainfall and run-off in Miami Valley, State of Ohio: Miami Conservancy Dist. Tech. Repts., pt. 8, 1921.
} 
record would cover a much larger part of each period between rains and that the entire process would be one of observation and measurement with less of the arbitrary feature of the present method. It would not be necessary to make current-meter measurements to develop rating curves at the subsidiary stations, as only change in storage, indicated by change in gage height, would be involved.

\section{METHODS FOR ESTIMATING DISCHARGE BY EVAPORATION FROM SOIL AND TRANSPIRATION FROM PLANTS}

Where the water table is near the surface the underground reservoir loses water by evaporation from the soil and by transpiration from plants. In some arid regions all or nearly all the ground water is disposed of in this way, and little or no water remains to be discharged through springs and seeps. In humid regions, however, the ground-water recharge is greater, and more soil moisture is supplied directly by the rains and melting snow, with the result that evaporation from the soil and transpiration from plants make less heavy demands on the ground water. For these reasons in humid regions there is generally an excess of ground-water discharge over the consumption by soil evaporation and transpiration, and this excess feeds the streams and maintains their flow during dry seasons.

Tests of the rate of discharge of ground water by capillary rise from the zone of saturation and subsequent evaporation from the soil were made by Slichter ${ }^{26}$ in 1905 , Lee ${ }^{27}$ in 1910 and 1911, Sleight ${ }^{28}$ in 1916, and other investigators more recently. In the Escalante Valley investigation, by White, ${ }^{29}$ records were obtained of evaporation from columns of undisturbed soil for comparison with evaporation from similar columns of soil that was dug up and artificially packed into tanks. The rate depends on the evaporativity of the atmosphere, the depth to the water table, and the texture of the soil, which controls both the height and the rate of capillary rise. The standard method of estimating the quantity of ground water lost by soil evaporation is to map the discharge area with reference to specified depths to the water table for different seasons, and to determine by means of tank experiments the rate of discharge for each range of depth. The problem is likely to be complicated by diversity in the texture of the soil, which may require a soil map of the discharge area and tank experiments for soils of different types.

\footnotetext{
26 Slichter, C. S., The underflow in Arkansas Valley in western Kansas: U. S. Geol. Survey Water-Supply Paper 153, pp. 43, 44, 1906.

${ }^{27}$ Lee, C. H., An intensive study of the water resources of a part of Owens Valley, Calif.: U. S. Geol. Survey Water-Supply Paper 294, pp. 57, 119, p1. 15, 1912.

26 Sleight, R. B., Evaporation from the surfaces of water and river-bed materials : Jour. Agr. Research, vol. 10, pp. 209-261, 1917.

20 White, W. N., A method of estimating ground-water supplies based on discharge of plants and evaporation from soil; results of investigations in Escalante Valley, Utah (released in manuscript form in 1930).
} 
Not much work has yet been done to establish the relations of the rate of soil evaporation to the factors that determine the rate. In most tank experiments data are obtained as to the atmospheric conditions and the depth to the water table, which give some basis for generalizations as to the variations of soil evaporation with variations in these factors. Generally records are also obtained of the rate of evaporation from a free water surface, so that the data as to soil evaporation can be expressed in terms of evaporation opportunity, or ratio of soil evaporation to evaporation from a free water surface. In the experiments by Sleight mechanical analyses were made of five soils used in the evaporation tests, and these analyses gave a basis for determining the evaporation opportunity for different sizes of grain with each of several depths to the water table. It is desirable that in future tank experiments tests be made of the mechanical composition, porosity, permeability, and capillary range of the soils used.

The rate at which soil discharge occurs may be controlled either by the rate at which the water can be lifted by capillarity to the level at which it is evaporated or by the rate at which it can be evaporated. The rate at which water is lifted through the soil from the water table to the point at which it is evaporated depends chiefly on the permeability of the soil, the height the water is lifted, and the capillary head or difference between the potential and actual capillary lift. In other words, the law of capillary rise is essentially Darcy's law of flow, in which the energy is furnished by capillary attraction instead of by hydrostatic head. Therefore, if the water table is very near the surface and the soil is very permeable the rate of discharge is determined by the possible rate of evaporation; but if the water table is at greater depth and the soil is less permeable the limiting factor may be the possible rate of capillary rise. Further investigation of the processes involved in soil discharge and of the controling laws should help to make the field methods more applicable and exact.

As a rule, vegetal discharge, which is effected by transpiration, is greater than soil discharge and occurs over wider areas, because the roots of certain plants lift water much higher than it is lifted by the capillary interstices of the soil. In arid regions nearly all the vegetal discharge of ground water is accomplished by plants of a few dominant and well-recognized species. ${ }^{30}$ To determine the quantity of ground water discharged by the ground-water plants in any particular area it is necessary to make a map of the area showing, so far as may be practicable, the distribution, density, and growth of

${ }^{30}$ Meinzer, O. E., Plants as indicators of ground water: U. S. Geol. Survey WaterSupply Paper 577, p. 1, 1927. 
the principal species, and to determine the rate at which they discharge water. Holes should also be dug to investigate the root habits of different ispecies of plants and to determine to what depths their roots extend to reach the capillary fringe and feed on water from the zone of saturation.

Maps showing areas of ground-water discharge and the distribution of dominant species of ground-water plants have been made for several' western valleys investigated by the Geological Survey-for example, the Independence district of Owens Valley, Calif., ${ }^{31}$ Sulphur Springs Valley, Ariz., ${ }^{32}$ Big Smoky Valley, Nev., ${ }^{33}$ Steptoe Valley, Nev., ${ }^{34}$ and parts of Escalante Valley, Utah. ${ }^{35}$ Information that will be helpful in the construction of such maps is given in several of the United States Geological Survey water-supply papers. ${ }^{36}$

The rate of vegetal discharge has generally been determined by means of tanks in which the different species are grown with measured quantities of water and in some investigations with different depths to the water table. In Lee's investigations in Owens Valley the discharge of salt-grass areas was investigated by means of tank experiments in which natural conditions were reproduced as nearly as practicable. Since the work by Lee was done tank experiments have been made in connection with several ground-water investigations. In the recent investigation by White in the Escalante Valley records of discharge were obtained from soil tanks in which water tables were maintained and salt grass, alfalfa, and greasewood were grown. Comparative data were obtained on tanks with undisturbed salt-grass sod and on tanks which were filled and planted in the ordinary way. The method was also introduced of obtaining the dry weight of vegetable matter produced in the tank experiments and determining the ratio of weight of water consumed to weight of dry matter produced. This ratio was then applied to data on dry matter naturally produced in order to compute the natural discharge of ground water. The method of determining vegetal discharge from daily fluctuations of the water table is described on pages 116-119.

In humid regions the problems of both vegetal and soil discharge of ground water are complicated by the soil moisture that is derived

${ }^{31}$ Lee, C. H., An intensive study of the water resources of a part of Owens Valley, Calif.: U. S. Geol. Survey Water-Supply Paper 294, pl. 25, 1912.

Meinzer, . O. E., and Kelton, F. C., Geology and water resources of Sulphur Spring Valley, Ariz. : U. S. Geol. Survey Water-Supply Paper 320, pls. 1, 2, 1913.

${ }^{83}$ Meinzer, O. E., Geology and water resources of Big Smoky, Clayton, and Alkalt Spring Valleys, Nev. : U. S. Geol. Survey Water-Supply Paper 423, pl. 2, 1917.

${ }^{34}$ Clark, W. O., and Riddell, C. W., Exploratory drilling for water and use of ground water for irrigation in Steptoe Valley, Nev.: U. S. Geol. Survey Water-Supply Paper 467, pl. 2, 1920 .

35 White, W. N., op. cit., pl. 1 (map by W. N. White and Depue Falck).

${ }^{36}$ See especially Water-Supply Paper 423, pp. 92-102, and Water-Supply Paper 577, already cited. 
directly from rain and snow. The problem of vegetal discharge is further complicated by the breaking down of the distinction between ground-water plants and plants that do not depend on ground water. No definite method has been developed for humid regions, but there are several possible lines of attack. More or less exact information on the extent of vegetal discharge of ground water in humid regions can be obtained from observations on the depth to the water table, the distribution of vegetation of different types, the relation of the root systems to the water table and overlying capillary fringe, and the amount of soil moisture and changes in soil moisture at different depths, especially in periods of drought. E. D. Burchard, district engineer in the Geological Survey, found from the record of an automatic water-stage recorder that the flow of a small stream in North Carolina had considerable daily fluctuations in the very dry month of July, 1926. These fluctuations were apparently caused by differences in the rate of evaporation in different parts of the 24-hour period, chiefly in vegetal and soil discharge of ground water, and they suggest a possible method for humid regions. It is likely, however, that such a method would give less than actual quantities. In the Pomperaug investigation some consideration was given to a possible method based on a ground-water rating curve (see p. 119), but the method actually used was merely to compute the groundwater evaporation as the difference between ground-water recharge and ground-water run-off. ${ }^{37}$

\section{STORAGE METHODS IN GENERAT}

If a capacity table or curve has been developed for a surface reservoir, a gage showing the changes in its water level will indicate for any period the net increase or decrease in storage. When the water level is rising it will register the excess in rate of recharge over rate of discharge, and vice versa. If it is known that there is no discharge in a certain period the record of rise will show the total rate of recharge during that period.

Because of the frictional resistance of water-bearing materials to the flow of the water from the intake to the discharge area of an underground reservoir the water table is almost nowhere a level surface, such as the water surface of an ordinary reservoir. Therefore, when this storage method is applied to underground reservoirs the depths to the water level in numerous wells are measured every week or month, or at other more or less frequent intervals, and continuous records are generally obtained on a few representative wells by means of automatic water-stage recorders. Levels are usually run

${ }^{37}$ Meinzer, O. E., and Stearns, N. D., A study of ground water in the Pomperaug Basin, Conn.: U. S. Geol. Survey Water-Supply Paper 597, pp. 138-139, 143, 1929. 
to the observation wells, and a series of contour maps of the water table at successive dates are constructed. From these maps or from the base data it is possible to compute the volume of water-bearing material that became saturated or drained in a given period.

In order to evaluate these results in terms of water instead of water-bearing material it is necessary to apply a factor generally known as the specific yield. This factor represents the interstitial space that is emptied when the water table declines, expressed as a percentage of the total volume of material that is unwatered. The same factor generally represents the space that is occupied by water going into storage when the water table rises. If, however, the material into which the water rises has been further desiccated by soil evaporation or vegetal discharge the amount of recharge is greater for each unit of rise.

The water level in a well is sensitive to every force that acts upon the body of water with which the well communicates. Hence, in most wells the water level fluctuates almost constantly, often in a complicated manner. The curve produced by an automatic waterstage recorder over a well gives an accurate record of the resultant of the forces that act upon the ground water. A well that extends only slightly below the water table generally records faithfully both recharge and discharge, but great care must be taken in applying this method to use only wells in which the water level is a continuation of the water table and not the upper surface of a column of water that is supported by artesian pressure in the water-bearing formation and that therefore fluctuates as a result of atmospheric or other changes in pressure. Even in a true water-table well there may be fluctuations produced by changes in temperature which affect capillarity, by confinement of air in the interstices of the overlying zone of aeration by rain or frozen ground, or by other causes that have nothing to do with recharge or discharge.

In summer, when the vegetation makes heavy demands on the soil moisture, most rainstorms do not contribute at all to the supply of ground water and hence do not affect the water levels in wells. But in unusually heavy and prolonged storms or series of storms water may penetrate to the water table and the water levels may rise, or at least their rate of decline may be diminished. ${ }^{38}$ Likewise recharge from stream flow or irrigation produces a rise in the water levels. ${ }^{39}$

In most regions of the United States recharge of the underground reservoirs occurs chiefly in the winter or in late autumn or early spring, when there is not much evaporation from the soil and little

3 Meinzer, o. E., and Stearns, N. D., op. cit., pl. 19.

20 Smith, G. E. P., Ground-water supply and irrigation in the Rillito Valley: Arizona Univ. Agr. Exper. Sta. Bull. 64, pp. 176-186, 1910. 
or no transpiration from plants to consume the water that falls as rain or is produced by the melting of snow. Hence in most regions the water table is usually at its lowest stage in the autumn and at its highest stage in the spring. In very cold regions, however, the ground is likely to be frozen continuously during a long period in the winter, and the lowest stage may occur just before the ground thaws out in the spring. In arid regions such as New Mexico, in which the principal rainy season occurs in the summer, the annual recharge may be relatively small, but there may be a rise in the water table either in the summer or in the winter. In regions such as California, in which the rainy season is in the winter, nearly all the recharge may occur during this season of relatively small discharge. In such regions the increase in storage from the lowest stage in autumn to the highest stage in spring may represent approximately the annual recharge. In irrigated districts recharge may, of course, occur during the irrigation season.

The report by Smith ${ }^{40}$ on the Rillito Valley, Ariz., includes a map on which are shown two sets of 5-foot contours of the water tableone set for the position of the water table on November 1, 1906, at the end of a dry season, and the other for its position on February 1 , 1907 , after the beginning of the spring flood season. It also contains a cross section of the valley on which are shown the profiles of the water table on successive dates in 1906 and 1907. From the rise in the water table shown in these illustrations and an assumed effective porosity, or specific yield, rough calculations were made of the recharge from the Rillito River in the flood season and of the probable supply of ground water annually available for irrigation. This method was applied more definitely and in more detail by Clark ${ }^{41}$ in the Santa Clara Valley, Calif., from 1912 to 1920, and by Lee ${ }^{42}$ in San Diego County, Calif., in 1914 and 1915. In both of these investigations numerous measurements were made of water levels in wells, data were obtained for estimating the specific yield, maps were prepared showing the contours of the water table at different dates, and computations were made of the seasonal increase in storage represented by the rise in the water table. More recently the same method has been used in making computations of net semiannual additions of water to or removals of water from the under-

${ }^{40}$ Smith, G. E. P., Ground-water supply and irrigation in the Rillito Valley: Arizona Univ. Agr. Exper. Sta. Bull. 64, pp. 194, 195, figs. 55, 56, 1910.

11 Clark, W. O., Ground-water resources of the Niles cone and adjacent areas, Callf.: U. S. Geol. Survey Water-Supply Paper 345, pp. 149-162, pl. 10, 1915; Ground water for irrigation in the Morgan Hill area, Calif.: U. S. Geol. Survey Water-Supply Paper 400, pp. 66-68, 76-105, pls. 6, 7, 1917; Ground water in Santa Clara Valley, Calif.: U. S: Geol. Survey Water-Supply Paper 519, pp. 58-75, 129-183, pls. 10-19, 1924.

12 Ellis, A. J., and Lee, C. H., Geology and ground waters of the western part of San Diego County, Calif, : U. S. Geol. Survey Water-Supply Paper 446, pp. 121-155, pls. 20-25, 1919. 
ground reservoir of the Mokelumne River area in California. ${ }^{48}$ For this purpose monthly or semiannual measurements were made of the water levels in about 500 observation wells. On account of uncertainties as to the specific yield and as to pressure effects in observation wells there may be large percentage errors in the computed recharge in all these investigations, and in the present stage of development of this method it is impossible even to state what may be the limits of error.

\section{SPECIFIC YIELD IN RELATION TO STORAGE METHODS}

Perhaps the greatest difficulty in the application of quantitative methods lies in the variability in the texture and hence in the hydrologic properties of the water-bearing materials. The hydrologic properties vary greatly, even with apparently slight differences in texture. Hence the ordinary geologic descriptions are quite inadequate for hydrologic purposes, and quantitative descriptions based on laboratory determinations have become essential. However, the hard rocks that yield their water largely from joints or crevices are not amenable to laboratory tests, and the incoherent materials are difficult to handle without disturbing and repacking, which may considerably change their texture and hydrologic properties.

The two hydrologic properties of greatest significance are specific yield and permeability. Mechanical analyses and determinations of porosity and moisture equivalent are useful chiefly as indirect means of determining these two essential hydrologic properties. Any quantitative method that does not involve either of these properties has a great advantage in avoiding the complications that result from the heterogeneity of the water-bearing materials. Most storage methods involve the perplexing problem of specific yield.

Seven more or less distinct methods have been used to determine specific yield, but none of them have been thoroughly developed. These methods ${ }^{44}$ are as follows: (1) Saturating samples in the laboratory and allowing them to drain; (2) saturating in the field a considerable body of material situated above the water table and above the capillary fringe and allowing it to drain downward naturally; (3) collecting samples immediately above the capillary fringe after the water table has gone down an appreciable distance, as it commonly does in summer and autumn; (4) ascertaining the

\footnotetext{
43 Stearns, H. T., Robinson, T. W., and Taylor, G. H., Geology and water resources of the Mokelumne area, California : U. S. Geol. Survey Water-Supply Paper 619, pp. 112-172, 185-188, 292-398, pls. 6-8, 13, 1930; also later report released in manuscript form (on file in public library, Lodi, Calif.).

4 Meinzer, O. E., The occurrence of ground water in the United States, with a discussion of principles: U. S. Geol. Survey Water-Supply Paper 489, pp. 67-76, 1923.
} 
volume of sediments drained by heavy pumping, a record being kept of the quantity of water that is pumped; (5) ascertaining the volume of sediments saturated by a measured amount of seepage from one or more streams; $(6)$ making indirect determinations in the laboratory with small samples by the application of centrifugal force; and (7) making mechanical analyses and determinations of porosity and estimating therefrom the specific retention and the specific yield. .

The laboratory saturation and drainage method consists of draining high columns of saturated materials by gravity and determining both the volume of material drained and the volume of water yielded. The volume of water yielded can be measured directly or can be computed from the porosity and the moisture content after draining. The columns must be high enough to avoid the vitiating effects of the capillary fringe, and care must be taken to prevent loss by evaporation. As molecular forces vary with the temperature of the water, the tests must be made at a uniform temperature, or corrections for temperature must be applied. As drainage continues for a long time at a diminishing rate, the specific yield should be determined for specified periods of draining. If the material is fine, appreciable drainage may occur during a period of several weeks.

This method was used by Hazen ${ }^{45}$ and by King. ${ }^{46}$ In both sets of experiments the yield of successive segments of the different columns of water-bearing materials was determined by deducting the moisture content after drainage from the porosity, but in the King experiments the volume of water drained from each column was also measured at appropriate intervals of time. ${ }^{47}$

Much careful work has been done on this method by White ${ }^{48}$ in 1925-1927, and by Taylor ${ }^{49}$ since 1927 . In White's work the following procedure was followed: A pit was dug and in the bottom a heavy metal cylinder, 36 or 42 inches high and 18 inches in diameter, was driven vertically into the water-bearing material within a few inches of the water table. The earth around the cylinder was then removed, and a metal plate was shoved under the cylinder and soldered to it, thus confining the column of undisturbed material in a water-tight vessel. Small wells were then sunk in the material in the cylinder,

ss Hazen, Allen, Experiments upon the purification of sewage and water at the Lawrence experiment station: Massachusetts Board of Health Twenty-third Ann. Rept., pp. 428-434, 1892.

46 King, F. H., Principles and conditions of the movements of ground water: U. S. Geol. Survey Nineteenth Ann. Rept., pt. 2, pp. 86-91, 1899.

${ }^{47}$ Meinzer, O. E., The occurrence of ground water in the United States, with a discussion of principles: U. S. Geol. Survey Water-Supply Paper 489, pp. 53-57, 1923. This paper gives a concise presentation and discussion of the Hazen and King experiments.

${ }^{40}$ White, W. N., Note in regard to investigation in the Escalante Desert, Utah: U. S. Geol. Survey Water-Resources Bulletin, March 10, 1927 (mimeographed reprint).

40 Stearns, H. T., Robinson, T. W., and Taylor, G. H., Geology and water resources of the Mokelumine area, California: U. S. Geol. Survey Water-Supply Paper 619, pp. 151$172,1930$. 
and the effects on the water levels in these wells produced by adding or withdrawing measured quantities of water were observed. From these data the specific yield was computed. This work was done in the autumn, when the water table was at its lowest stage; hence the tests were made on the material through which the water table fluctuates and which is therefore subjected to alternate draining and resaturation.

In the work by Taylor the general method developed by Whits was employed, but improvements were made in the technique, and extensive tests were made to determine the effects of changes in temperature and the periods required in different materials to reach approximate capillary equilibrium.

The method of field saturation and drainage is similar in principle to the laboratory method. A plot of land is selected where the water table and capillary fringe are at sufficient depth below the surface. The material underlying the plot is thoroughly wetted by applying water at the surface and is then allowed to drain, care being taken to avoid much evaporation. After a sufficient period of draining samples are taken for determination of moisture content and porosity, and the specific yield is computed as the difference between these two. This method has been used by Israelsen ${ }^{50}$ and other students of soil water. If the specific yield of material below the soil that is more representative of the water-bearing material is desired, it is necessary to apply enough water to wet this deeper material and to obtain samples from it. In some situations it might be advantageous to dig pits to the material to be tested.

In the direct sampling method samples are obtained by boring into the material immediately above the capillary fringe after the water table has deelined appreciably, and the moisture content and porosity of the samples are determined. This is essentially the method used by Lee ${ }^{51}$ in, San Diego County, Calif. The essential feature in this method is to take a sample where the water table has gone down, as it generally does during the dry summer season in California. For the most conclusive results the sample should be taken from a point which in the preceding wet season was below the water table and which at the time of taking the sample is far enough above the water table not to be seriously affected by the capillary fringe. Where the fluctuation of the water table is less than the thickness of the capillary fringe the most significant samples are those taken just above the fringe. As in practice this position can not be very definitely determined it is advisable to take samples at several

\footnotetext{
${ }^{50}$ Israelsen, O. W., Studies in capacities of soils for irrigation water: Jour, Agr. Research, vol. 13, pp. 1-28, April 1, 1918.

51 Ellis, A. J., and Lee, C. H., Geology and ground waters of the western part of San Diego County, Calif,: U. S. Geol. Survey Water-Supply Paper 446, pp. 121-123, 1919.
} 
levels, as was done by Lee. In making tests of this kind it is essential to ascertain that the part of the deposit from which the sample is taken has not received any recent contribution of water from rain or irrigation and has not been exposed to evaporation or to absorption by plants, both of which consume water that is retained against gravity by molecular attraction.

The pumping method consists in observing the lowering of the water table and hence the volume of sediments drained by pumping a measured volume of water. The specific yield is, of course, the ratio of the volume of water pumped to the volume of material drained. Serious errors may be introduced by pumped water returning to the water table and by other percolation into or out of that part of the underground reservoir which is supplying the pumped water. This method was used by Clark ${ }^{52}$ with records obtained in the Morgan Hill area, California, and is more or less applicable to other areas having water-table conditions and heavy seasonal pumpage.

The recharge method, which is the converse of the pumping method, consists of observations on the seepage losses from streams or canals and on the resultant rise of the water table, from which is computed the volume of material saturated. It is, of course, merely the storage method of determining recharge, with the specific yield instead of the quantity of water as the unknown factor.

The moisture-equivalent and mechanical-analysis methods are based on investigations by Briggs, Veihmeyer, and others ${ }^{53}$ on the relations between the moisture equivalent or mechanical composition of the water-bearing materials, on one hand, and the specific retention, on the other hand. The specific yield is computed as the difference between porosity and specific retention as determined by one of these indirect methods. Both of these methods are valuable, at least in giving a general check on the results from other methods, and they deserve further investigation.

\section{METHODS FOR ESTIMATING DISCHARGE FROM DAIIY FLUCTUATIONS OF THE WATER TABLE}

In most localities in which plants draw water from the zone of saturation there are daily fluctuations of the water table ranging from a small fraction of an inch to several inches. To obtain curves of these daily fluctuations the most sensitive water-stage recorders are used.

52 Clark, W. O., Ground water for irrigation in the Morgan Hill area, Calif.: U. S. Geol. Survey Water-Supply Paper 400, pp. 84-86, 1917.

${ }^{53}$ Briggs, L. J., and McLane, J. W., The moisture equivalents of soils: U. S. Dept. Agr. Bur. Soils Bull. 45, 1907. Briggs, L. J., and Shantz, H. L., The wilting coefficient for different plants and its indirect determination: U. S. Dept. Agr. Bur. Plant Indùstry Bull. 230, 1912. Briggs, L. J., Martin, O. F., and Pearce, J. R., The centrifugal method of mechanical soil analysis: U. S. Dept. Agr. Bur. Solls Bull. 24, 1904. Veihmeyer, F. J., and Hendrickson, A. H., The moisture equivalent as a measure of the fleld capacity of soils (unpublished manuscript). 
During the daytime the plants withdraw water and consequently lower the water table. This drawdown of the water table produces a head in the underlying strata, which causes continual upward percolation. Therefore at night, when there is little or no withdrawal by plants, the water table rises much as the water level in a well rises when pumping is stopped. The daily transpiration is equal to the upward percolation throughout the 24-hour period plus or minus the comparatively small amount of water represented by the net decline or rise of the water table during the same period. The average rate of upward percolation occurs when the water table stands about midway between its lowest and highest daily stages. This occurs twice a day-during the declining phase, some time in the afternoon, and during the rising phase, usually late in the night. The nocturnal mid-stage occurs at a time when there is little or no withdrawal from the zone of saturation, and hence at a time when the replenishment of storage that causes the rise of the water table is approximately the average rate of upward percolation for the 24-hour period. ${ }^{54}$ In order to ascertain the quantity of water withdrawn by the plants from the zone of saturation it is therefore necessary to determine the quantity of water that is required to raise the water table an inch, a foot, or other unit of height-that is, to determine the specific yield of the material through which the water table fluctuates.

Daily fluctuations of the water table were observed by King ${ }^{55}$ in his experiments at Madison, Wis., in 1888 and subsequent years, and he recognized their possible significance in recording the discharge of ground water through vegetation. However, he dismissed the subject as too complicated for solution without more elaborate investigation. The method was successfully applied by G. E. P. Smith, in 1917 and subsequent years, by the use of automatic water-stage recorders on wells in tracts of cottonwood and mesquite and later also on wells in tracts of salt grass and alkali sacaton. To Smith, therefore, belongs the credit for the introduction of this method. He also developed the theory of upward percolation and showed that the daily vegetal discharge could be computed from the rate of rise of the water table at the nocturnal mid-stage if the specific yield were known. ${ }^{56}$

In 1925 the United States Geological Survey undertook an intensive investigation to develop this promising method and especially to devise means for interpreting the fluctuations in terms of quantity

\footnotetext{
54 Smith, G. E. P., The effect of transpiration of trees on the ground-water supply (unpublished paper given before the Geological Society of Washington, Nov. 22, 1922). See Washington Acad. Sci. Jour., vol. 14, p. 160, 1924.

65 King, F. H., Observations and experiments on the fluctuations in the level and rate of movement of ground water on the Wisconsin Agricultural Experiment Station farm at Whitewater, Wis.: U. S. Weather Bur. Bull. 5, 1892.

6 Smith, G. E. P., Washington Acad. Sci. Jour., vol. 14, p. 160, 1924.
} 
of ground water discharged by the plants. For this purpose the Escalante Valley, Utah, was chosen, and W. N. White, who had already done considerable hydrologic work in that valley, was assigned to make the investigation. A preliminary statement of the results of the first two years of his work on this method was published in $1927,{ }^{57}$ and a comprehensive report on the results of all three years of his work is nearly ready for publication. ${ }^{58}$

In the course of the Escalante Valley investigation three methods of determining the specific yield were devised and put into practice. One of these methods consisted of driving cylinders and making direct tests as above described (p. 114). In another method several soil tanks were used in which the three principal ground-water plants of the region-alfalfa, salt grass, and greasewood-were grown. The natural hydraulic conditions were reproduced as closely as possible, daily water-table curves were obtained comparable to those obtained in the field, and observations of the quantity of water fed into the tanks to replace the upward percolation were made at frequent intervals. Thus data were obtained for the evaluation of every process involved, including the interpretation of the rise and. fall of the water table in terms of quantity of water. In the third method the ratio of dry alfalfa hay produced in the tank experiment to the quantity of water consumed was determined, and this ratio was used to compute the water consumed by a known weight of alfalfa growing as a ground-water plant in a field in which a well was dug and a water-stage recorder was operated. Thus it became possible to interpret the curve of water-table fluctuations in terms of quantity of water and hence to compute the specific yield. This might be regarded as an eighth method of determining specific yield. Similar ratios were also determined for salt grass and greasewood, and these were applied directly to the seasonal growth of these species in the field to compute the quantities of water that they discharged. As these computations did not involve the fluctuations of the water table they served as a check on the daily fluctuation method.

The studies of the daily fluctuations of the water table in areas of vegetal discharge have given valuable results. However, the application of the method is complicated in several ways, chiefly by the variability in the texture of the soil and water-bearing material as it affects the specific yield, permeability, capillarity, and root

67 White, W. N., Notes in regard to the work in the Escalante Valley, Utah, on the discharge method of estimating ground-water supplies : U. S. Geol. Survey Water-Resources Bulletin, Mar. 10, 1927, pp. 22-29. See also Washington Acad. Sci. Jour., vol. 17, pp. 238-240, 1927.

ts White, W. N., A method of estimating ground-water supplies based on discharge by plants and evaporation from soil; results of investigations in Escalante Valley, Utah (released in manuscript form in 1930). 
distribution. The method is not applicable where the water-bearing formation consists of very permeable material without interstratified confining beds, because the fluctuations are too slight to be accurately recorded by available instruments, and, moreover, the mid-stage of the rising phase, as well as that of the declining phase, occurs while discharge is occurring. The method will probably have to be used to determine the approximate consumption of water by the principal species of ground-water plants, and these results will have to be applied to maps that will show in as much detail as practicable the area, density, and growth of each of these species.

\section{METHOD BASED ON GROUND-WATER RATING CURVE}

In the Pomperaug investigation weekly measurements were made of the depths to the water levels in a number of observation wells, and the average depth for each week was plotted against the corresponding ground-water run-off. It was, of course, found that the run-off for a given stage of the water table was much less in summer, when vegetal discharge and soil evaporation were active, than in the colder part of the year, when there was very little loss by these processes. A curve was drawn through or near the coordinate points for winter weeks, according to the empiric method used in making rating curves for surface streams. This gave a rating curve for ground-water run-off during the winter. It was hoped that the curve would show approximately the total ground-water discharge in summer and that the ground-water evaporation could be obtained by subtracting the ground-water run-off from the total discharge as shown by the curve. In fact, however, this difference seems to give minimum rather than actual figures for ground-water evaporation, because the roots of plants and the soil capillaries do not wait for the water to appear at the surface but pump it up from some depth..$^{50}$ Further investigation will be required to determine whether it will be practicable under any circumstances to use the stage of the water table as an index either of ground-water run-off or of total groundwater discharge.

\section{SAFE YIELD AS COMPARED WITH NATURAL INTAKT AND DISCHARGE}

The safe yield of a water-bearing formation, or the practicable rate of withdrawing water from it perennially for human use, may be either greater or less than the rate of natural recharge or discharge as determined before heavy withdrawals are begun. It may

50 Meinzer, O. E., and Stearns, N. D., A study of ground water in the Pomperaug Basin, Conn., with special reference to intake, and discharge: U. S. Geol. Survey WaterSupply Paper 597, fig. 13, 1928. 
be less because natural discharge can not be wholly prevented, even by heavy withdrawals through wells. On the other hand, it may be greater because of artificial increase of the rate of recharge.

Before any large ground-water developments are made the average rate of discharge for any long period is obviously about equal to the average rate of recharge. When heavy pumping from wells is begun the water table declines, and this results in curtailing the loss from the underground reservoir by spring flow, seepage, soil evaporation, vegetal discharge, and perhaps underground leakage. It is, however, not practicable to prevent all the natural discharge even if the water table is greatly lowered. Obviously the water that is at first pumped is largely water taken out of storage. As pumping progresses the water table continues to decline and the salvage from natural discharge increases, until, if the safe yield is not exceeded, the pumpage is eventually all salvage, and there is no further net withdrawal from storage and no further permanent lowering of the water table. If, however, the pumpage exceeds the safe yield, withdrawal from storage will continue and the water table will persistently decline. In all investigations of undeveloped underground reservoirs the factor of unsalvageable natural discharge should be recognized.

Surface reservoirs that are full have no capacity for additional storage. Underground reservoirs are also limited in their capacity, though not so definitely as surface reservoirs. In a long period of wet weather the water table may become so high and effluent seepage may become so general that the underground storage will not be increased even by heavy precipitation, and after the rains cease stored water will be rapidly discharged until the water table reaches a more normal stage. This temporary storage capacity depends largely on the relief of the land, as has been pointed out by George Otis Smith. ${ }^{50 a}$ If the land surface is nearly level there is little opportunity for the underlying water-bearing beds to drain, and hence the springs will decline or dry up completely while the underground reservoir remains nearly full. On the other hand, if the region is deeply dissected the lowland springs may continue to flow with little decrease in volume throughout long periods of drought, during which they are gradually draining the underground reservoir. If prior to a wet season the water table has been lowered either by the flow of springs or by pumping from wells, the available capacity of the underground reservoir is increased, and more of the surface water will go into underground storage than would otherwise be possible. In this respect the recharge may be increased by use.

In order to utilize fully the flow of a stream, storage is required to hold the excess water of high stages for use in times of small 
flow or whenever there may be need for the water. Many of the underground reservoirs are so large that they have capacity to carry over great quantities of water not only from a wet season to the following dry season but also from a period of wet years to a period of dry years. However, to utilize these reservoirs fully it is necessary to pump enough water out of them to make room for all the inflow during the wettest seasons and during the periods of successive years of heavy precipitation. This was well illustrated by some of the underground reservoirs of southern California, whose water tables, under heavy pumping for irrigation, went down a little lower each summer than they had risen in the previous winter, until it appeared that excessive depletion must inevitably compel reduction in irrigation. Then came a period of wet winters when recharge occurred to a remarkable extent and the water levels rose beyond all expectations. ${ }^{60}$

The principle of increasing recharge by use was recognized by Smith ${ }^{61}$ and Wolff ${ }^{62}$ in early quantitative work in this country and has generally received due consideration in more recent investigations. In all investigations of undeveloped ground-water supplies the possible effect of use in increasing the yield should be recognized and so far as practicable should be evaluated. In making investigations where heavy pumping is already in progress, estimates based on a few years of normal or subnormal precipitation may be too low because they do not sufficiently take into account the great recharge that may occur in a depleted underground reservoir during a season of exceptionally high precipitation.

Artificial recharge can be accomplished in some places by draining surface water into wells, spreading it over tracts underlain by permeable material, temporarily storing it in leaky reservoirs from which it may percolate to the water table, or storing it in relatively tight reservoirs from which it is released as fast as it can seep into the stream bed below the reservoir. Artificial recharge by some of these methods has been practiced in the United States and other countries. It was suggested by Hilgard ${ }^{63}$ in 1902 for southern California, where it has since received considerable investigation and has been adopted as a conservation measure. ${ }^{64}$ Drainage

${ }^{\text {B0 }}$ Ebert, F. C., Records of water levels in wells in southern California: U. S. Geol. Survey Water-Supply Paper 468, pls. 2, 3, 4, 1921.

amith, G. E. P., op. cit., p. 189.

Wolff, H. C., The utilization of the underflow near St. Francis, Kans.: U. S. Geol. Survey Water-Supply Paper 258, pp. 104-107, 1911.

63 Hilgard, E W., Subterranean water supply of the San Bernardino Valley: U. S. Dept. Agr. Bull. 119, pp. 133-134, 1902.

e Lee, C. H., Subterranean storage of flood water by artificial methods in San Ber'nardino Valley, Calif.: California Conservation Comm. Rept. for 1912, pp. 335-400, 1913. Tate, C. B., Spreading water for flood control: Southern California Assoc. Members Am. Soc. Civil Bng. Bull., vol. 1, No. 4, pp. 76-86, Los Angeles, 1919 . Post, W. S., Santa Ana investigation, flood control and conservation: California Dept. Public Works Div. Ing. and Irr. Bull. 19, pp. 165-179, 1929. 
into wells has been practiced in many parts of the United States, chiefly to reclaim swampy land or to dispose of sewage and other wastes. ${ }^{65}$ The drainage of sewage or other wastes into wells can not be approved, because it may produce dangerous pollution of water supplies. Drainage of surface water into wells to increase the ground-water supply for rice irrigation in Arkansas is now under consideration. ${ }^{66}$ Water spreading has been practiced to a considerable extent in southern California, partly to decrease the effects of flood but largely to increase the supply of ground water. Storage in ordinary reservoirs and subsequent release has frequently been considered, and the unavoidable leakage of some reservoirs has been used to increase the ground-water supply. ${ }^{67}$ Artificial recharge by damming stream channels in the permeable lava rocks of the Hawaiian Islands has been considered. ${ }^{68}$ In ground-water investigations that involve the question of safe yield attention should as a matter of course be given to the possibilities of artificial recharge.

\section{STORAGE METHODS APPIIED WHERE USE HAS BECOME LARGE}

If an underground reservoir is heavily pumped a study of the relations of the water levels to the amount of pumpage is likely to give more reliable information as to the safe yield than can be obtained by any method of studying an undeveloped reservoir. If the water levels in the wells remain virtually stationary during a considerable period of pumping it may be concluded that during this period the rate of recharge has been about equal to the rate of discharge, including both natural discharge and withdrawals from wells. This principle was utilized by Mendenhall ${ }^{69}$ in his groundwater investigations in San Bernardino Valley, Calif., early in the present century, where already there was heavy pumping for irrigation. He found that the records on two wells under observation for several years showed a net decline in water level in all years, though in two years of somewhat more than average precipitation the decline was only slight. He therefore concluded that in those two years the pumpage was virtually supplied by recharge but that in all other years there was a draft on storage.

\footnotetext{
65 Horton, R. E., Drainage of ponds into drilled wells: U. S. Geol. Survey Water-Supply Paper 145, pp. 30-39, 1905. Fuller, M. L., Drainage by wells: U. S. Geol. Survey Water-Supply Paper 258, pp. 6-22, 1911.

oo Thompson, D. G., Ground-water supplies for rice irrigation in the Grand Prairie region, Arkansas: U. S. Dept. Interior Press Mem. 49844, January 26, 1931.

${ }^{67}$ Meinzer, O. E., Renick, B. C., and Bryan, Kirk, Geology of No. 3 reservoir site of the Carlsbad irrigation project, New Mexico, with respect to water-tightness: U. S. Geol. Survey Water-Supply Paper 580, pp. 21-25, 1927.

68 Stearns, H. T., and Clark, W. O., Geology and water resources of the Kau District, Hawail: U. S. Geol. Survey Water-Supply Paper 616, p. 21, 1930. The method had been suggested by Lincoln McCandless in Honolulu Advertiser, June 21, 1926.

*9 Mendenhall, W. C., The hydrology of San Bernardino Valley, Calif.: U. S. Geol. Survey Water-Supply Paper 142, pp. 56-67, 1905.
} 
Regardless of the manner in which the water levels fluctuate, if at the end of any period they return approximately to the position they had at the beginning of the period the record of pumpage furnishes a measure of the recharge during the same period minus the natural loss. In the Niles cone, in California, the water levels in the autumn of 1918 had returned to almost the identical levels of the autumn of 1913 , although in the intervening period there were notable fluctuations in level as a result of wet and dry years. Bailey's inventory of the ground-water supply ${ }^{70}$ covered this 5-year period in which there was practically no net change in storage.

Under such conditions two uncertainties remain which affect the practical conclusions as to safe yield-first, as to how much natural discharge there was during the period and especially how much salvageable natural discharge; and, second, as to how nearly the recharge during the period represents the average rate of recharge or how much it was above or below the average. If it is known that during a period of such stationary or recurring conditions of the water table the rate of recharge has not been above the average, it may be concluded that pumpage has not exceeded the safe yield. On the other hand, the mere fact of essential equilibrium between recharge and discharge gives no indication of the maximum salvageable discharge-that is, of the maximum pumpage that would be practicable. If the rate of pumping is increased, the water table will decline and consequently the rate of natural discharge will be diminished. If the safe yield has not been exceeded, this process of lowering the water table and decreasing the natural discharge will proceed until eventually the diminution in the rate of natural discharge will equal the increase in the rate of pumping, the aggregate of the two kinds of discharge will again be balanced by recharge, there will no longer be any net withdrawal from storage, and the water table will be approximately stabilized in its new position. If the safe yield has been exceeded and the new rate of pumping is greater than the maximum possible salvage, then, obviously, the pumps will continue to draw upon the storage and the water table will continue to decline indefinitely. If with a given rate of pumping the water table is approximately stabilized and the natural discharge is known to be small or to have been reduced nearly to the practicable limit, it.may be concluded that the pumpage furnishes an approximate measure of the safe yield and that the ground-water supply has been fully developed but not overdeveloped.

Talley, Paul, Engineering investigation of percolation from Alameda Creek and groundwater studies on Niles cone: California State Water Comm. Third Bienn. Rept., pp. 105, $106,1921$.

$31558^{\circ}-32-9$ 
The great advantage in basing computations on a period of stationary water levels or on a period in which the water levels are about the same at the end as at the beginning of the period is that there is no net withdrawal from or addition to the storage, and consequently the specific yield of the water-bearing material is not involved. If, however, the water table declines persistently or if it is desired to make monthly or annual estimates of the recharge, it becomes necessary to determine the specific yield or at least the capacity of the underground reservoir for each foot of saturation within the belt through which the water table migrates. In regions that have distinct wet and dry seasons, such as California and parts of the Hawaiian Islands, the recharge during the dry season may be negligible in quantity. If natural discharge has become relatively small, the pumpage in the dry season may therefore represent approximately the reduction in storage. If both the pumpage and the average decline of the water table are known, the approximate capacity of the underground reservoir for each foot of depth can be computed, and this figure can be used in computations of recharge during the wet season. In applying this method adequate precautions must, of course, be taken to get the average position of the water table for the entire area underlain by the underground reservoir and to distinguish between water levels that represent the water table and those that represent artesian pressure. This method was used by McCombs ${ }^{71}$ in the artesian basin in the vicinity of Honolulu, where there is continuous heavy withdrawal from wells but only a negligible amount of natural discharge and practically no recharge during the dry seasons, and where the water-bearing lava rock is so permeable that there is almost no loss of head due to friction and the water table in the intake area is almost exactly recorded by the water levels in the artesian wells.

By this method the average specific yield of the water-bearing material that has been drained can be determined, provided, of course, that the area of the water table in the underground reservoir is known with reasonable accuracy. This is the fourth or pumping method described above. However, it.should be remembered that in the procedure followed by McCombs the specific yield is not required but only the storage for each foot of depth.

\section{ILARAGE METHODS}

In some places there is good evidence of leakage from one underground reservoir into another. If the leakage occurs as underflow

71 McCombs, John, Methods of estimating safe yield of Fonolulu artesian area : Honolulu Sewer and Water Comm. Rept., 1927, pp. 61-65, 
through a relatively definite underground channel it can be estimated by one of the conduit methods described below, as, for example, in the investigation made by Slichter ${ }^{72}$ in 1904 of the underflow at the narrows of the Rio Grande near El Paso, Tex. If, however, the leakage occurs by percolation through the rocks at considerable depths it may be quite impracticable to estimate the quantity of water that is lost. An example of such a condition is afforded by the probable underground escape of water from Alkali Spring Valley into Clayton Valley, in Nevada. ${ }^{73}$

After wells have been drilled into an artesian formation much artesian water may escape into permeable beds above the confining bed through defective or corroded well casings. Recently a successful method has been developed for measuring this underground loss of artesian water. The principle involved is very simple. A specially constructed current meter is lowered into the well, where it records the velocity of the water at any depth desired. With the velocity and the diameter of the well known, the rate of flow at any point can be determined. Hence a series of measurements taken at successive levels from the bottom to the top of the well will show just where the water enters and in what amounts, where it leaks out and in what amounts, and how much is delivered at the surface. For certain investigations it may be necessary to use apparatus for measuring the diameter of a well at any depth, but thus far no serious difficulties have arisen in the leakage work on account of uncertainty as to the diameter.

In connection with drainage investigations on the Twin Falls South Side project, in Idaho, from 1910 to 1914, a Price current meter, such as is used by the United States Geological Survey in stream gaging, was used by W. G. Sloan, of the Department of Agriculture, and W. B. Heroy, of the Geological Survey, to measure the discharge of wells and also to determine the levels at which the water entered the wells. Beginning in 1918, a Price meter was successfully used by the Geological Survey for making a systematic survey of leakage of artesian wells in Honolulu, first by $R$. D. Klise and later by John McCombs and others. In 1925 a current meter that is much better adapted for the well work was designed by Carl H. Au and was used by A. G. Fiedler, who further developed the method in leakage investigations in the Roswell artesian basin, New Mexico, and in other localities. ${ }^{74}$ A so-called "kink finder," or

\footnotetext{
Ilichter, C. S., Observations on the ground waters of Rio Grande Valley : U. S. Geol. Survey Water-Supply Paper 141, pp. 9-13, 1905.

${ }^{73}$ Meinzer, O. E., Geology and water resources of Big Smoky, Clayton, and Alkall Spring Valleys, Nev. : U. S. Geol. Survey Water-Supply Paper 423, pp. 147-150, 1917.

${ }^{74} \mathrm{McC}$ Combs, John, and Fiedler, A. G., Methods of exploring and repairing leaky artesian wells, with a preface by 0 . W. Meinzer: U. S. Geol. Survey Water-Supply Paper 596, pp. 1-32, 1927. The work of Sloan and Heroy was not mentioned in this paper because it was not at that time known to any of the authors.
} 
automatic gage for determining the diameter of a well from bottom to top, invented by P. B. Whitney, was successfully used, in 1927, in a 4,700-foot well of the Repollo Oil Co., near Boulder, Colo. ${ }^{75}$

In an investigation in the Winter Garden area, in Texas, it was necessary to determine whether salty water from one formation is entering a fresh-water formation through wells with defective casings. For this purpose an apparatus was devised which can be lowered into the wells and will indicate the electric conductivity and therefore the degree of salinity of the water at different depths. ${ }^{78}$

\section{ROCK FORMATIONS AS CONDUITS}

\section{GENERAL CONDITIONS}

Ground water travels laterally from the intake areas to the discharge areas. On account of the viscosity of the water and the small size of the interstices of the water-bearing material through which it usually percolates, there is a very appreciable resistance to its flow. Hence the rate of recharge is controlled not only by the intake facilities and the quantity of surface water that reaches the intake area but also by the capacity of the formation to carry water from the intake area to the area of natural discharge or to the wells where the water supply is to be recovered. If the distance from the intake area to the discharge area is great, as it is in some of the large artesian basins, the problem of safe yield relates to the capacity of the formation as a conduit rather than to its capacity as a reservoir. Quantitative methods are therefore required to estimate the transmission capacities of water-bearing formations.

\section{METHODS BASED ON FIELD TESTS OF VELOCITY}

The rate of flow of a surface stream at a selected cross section is determined by measuring the velocity of the water in each unit of the cross section. The rate of flow through each unit is the product of the velocity by the area of the unit, provided the flow is at right angles to the cross section. The total flow of the stream is, then, the sum of the flows through all the units of the cross section. ${ }^{77}$

The same principle is applied in estimating the flow of ground water, but different means must be used for measuring the velocity and cross-section area, and a third factor, which may be called the

\footnotetext{
T5 Described by Mr. Whitney in letter of May 14, 1927, to the Director, U. S. Geological Survey.

${ }^{78}$ Survey of the underground waters of Texas: U. S. Dept. Interior Press Mem. 50678, Feb. 16, 1931.

77 Hoyt, J. C., and Grover, N. C., River discharge, 4th ed., pp. 3, 4, 44-81, New York, John Wiley \& Sons, 1927.
} 
effective porosity, is involved. The velocity of a surface stream is generally measured with a current meter, but this instrument is obviously not available for measuring the velocity of gtound water. For this purpose use has been made of salts and dyes, which are: introduced into the ground water through an upstream well and later detected in one or more downstream wells, the velocity being computed from the observed interval of time and the measured distance between the wells. Common salt was first used by European hydrologists and was detected in the downstream wells by chemical tests for chloride in successive samples taken from these wells. Later the more convenient electrolytic method was devised in this country by Slichter.

One of the pioneers in developing methods for measuring the velocity of ground water was the German hydrologist A. Thiem, ${ }^{78}$ who made investigations leading to the development of ground-water supplies in many cities of Germany and published the results of his work in several papers that appeared between 1879 and 1892 . He used common salt in his experiments because it is inexpensive, readily soluble, easily detected by the test for chloride, and not objectionable in any way. His method was to dig two test wells approximately in line with the direction of the movement of the ground water as determined from the slope of the water table. He then dosed the upper well with salt and at suitable intervals took samples from the lower well which he tested for their chloride content.

A notable advance in the methods of measuring the velocity of ground water was made in this country when the electrolytic method was developed by Slichter. ${ }^{79}$ His first work was done in 1901 in the Arkansas River Valley, near Garden City, Kans. ${ }^{80}$ In succeeding years he and his associates made measurements of the velocity of ground water by the electrolytic method on Long Istand ${ }^{81}$ and in the valleys of the Los Angeles, ${ }^{82}$ Hondo, ${ }^{88}$ San Gabriel, ${ }^{83}$ and Mohave ${ }^{83}$

78 Thiem, A., Verfahren für Messung natürlicher Grundwasser-geschwindigkeiten : Poly. Notizblatt, vol. 42, p. 229,1887 . Slichter, C. S., Theoretical investigation of the motion of ground waters: U. S. Geol. Survey Nineteenth Ann. Rept., pt. 2, pp. 297-384 (see especially the bibliography, pp. 380-384), 1898; The motions of underground waters: U. S. Geol. Survey Water-Supply Paper 67, pp. 46-48, 1902.

Slichter, C. S., The motions of underground waters: U. S. Geol. Survey Water-Supply Paper 67, 1902; Field measurements of the rate of movement of underground waters: U. S. Geol. Survey Water-Supply Paper 140, 1905.

so Slichter, C. S., The underflow in Arkansas Valley in western Kansas: 'U. S. Geol. Survey Water-Supply Paper 153, 1906.

st Slichter, C. S., Field measurements of the rate of movement of underground waters; U. \$. Geol. Survey Water-Supply Paper 140, pp. 65-85, 1905. Veatch, A. C., Slịchter, C. S., Bowman, Isaiah, Crosby, W. O., and Horton, R. E., Underground water resources of Long Island, N. Y.: U. S. Geol. Survey Prof. Paper 44, pp. 86-115, 1906.

Hamlin, Homer, Underflow tests in the drainage basin of Los Angeles River: U. $\beta$. Geol. Survey Water-Supply Paper 112, 1905.

8 Slichter, C. S., Field measurements of the rate of movement of underground waters : U. s. Geol. Sarvey Water-Supply Paper 140, pp. 50-64, 1905. 
Rivers, in California, the Rio Grande near El Paso, Tex., ${ }^{84}$ the South Platte River, in Nebraska, ${ }^{85}$ and the Republican River, in Kansas. ${ }^{86}$ The method has been standardized and has been extensively used in ground-water work, both in the United States and in other countries.

The electrolytic method depends on the fact that the electric conductivity of water increases with its concentration of dissolved salt, which acts as an electrolyte. Simple electric apparatus is used with a battery to generate the current and an ordinary or recording ammeter to measure the current. The progress of the salt is recorded when the current is passed through the water from the upstream well to a downstream well, and its arrival in one of the downstream wells is indicated when the current passing from the casing of that well to an electrode inside of it suddenly increases. Many mechanical difficulties are involved in the installation of the wells and the application of the electrolyte, which may introduce large errors in the results or may completely vitiate the experiments. The difficulties are especially serious where the velocities are small.

Dye has been used chiefly in sanitary investigations, largely to trace the course of rather definite underground streams, such as occur in limestone, and to determine whether certain water supplies receive contributions from polluted sources. The dye most commonly used is the chemical called uranin, which is the sodium salt of fluorescein and which has often been incorrectly called fluorescein. This is a harmless but very strong and stable dye that colors the water green. The dye method was described by Dole ${ }^{87}$ in 1906 , in a paper which also contains a historical sketch of the development of the method and a bibliography. Dye tests were made by Dr. Dionis des Carrières in 1882, during a severe epidemic of typhoid fever in the city of Auxerre, in France, and since that time frequent use has been made in France of various dyes to study the movements of ground water. In 1899 elaborate investigations were made by Trillat of the value of certain dyes as flow indicators and of the effects on them of passage through common soils. The fluoroscope, for detecting dyes when present in great dilution, was invented by Trillat and was perfected by Marboutin. Dye tests have frequently been made in the United States by sanitary engineers and

84 Slichter, C. S., Observations on the ground waters of Rio Grande Valley : U. S. Geol. Survey Water-Supply Paper 141, pp. 9-13, 1905.

${ }_{85}$ Slichter, C. S., and Wolff, H. C., The underfiow of the South Platte Valley: U. S. Geol. Survey Water-Supply Paper 184, pp. 9-12, 1906.

${ }^{86}$ Wolff, H. C., The utilization of the underflow near St. Francis, Kans.: U. S. Geol. Survey Water-Supply Paper 258, pp. 98-119, 1911.

${ }^{8}$ Dole, R. B., Use of fluorescein in the study of underground water: U. S. Geol. Survey Water-Supply Paper 160, pp. 73-85, 1906. 
others, and a good example is afforded by the series of tests made by Stabler. ${ }^{88}$

In 1921 and subsequent years uranin dye was successfully used by Stiles and his assistants ${ }^{89}$ in an investigation to determine the extent to which bacteria are carried through formations of sand. This investigation, which was made at an experiment station near Fort Caswell, N. C., by the United States Public Health Service, with the cooperation of the United States Geological Survey, involved a minute 3-dimensional survey of the direction and rate of movement of the ground water and made a notable contribution in demonstrating the use of the dye method in fine-grained materials and in providing means for detailed study of the movement of ground water.

The use of a dye probably affords the most accurate method of studying in detail the movements of ground water. It may be rather easily applied in some creviced rocks that have relatively definite underground streams, but in porous rocks with small interstices the dye may be very elusive, and the method may be found to be much more laborious and difficult than would appear on casual consideration. In the Fort Caswell experiment about 550 test wells were sunk in addition to some trenches, and the exact distribution of the uranin was determined.

To estimate the flow of ground water, whether by electrolytic, chemical, or dye methods, it is necessary to ascertain with some degree of accuracy the cross section through which the water flows and the velocity of flow through each unit of the cross section. This is accomplished by sinking test wells and to some extent by studying the records of existing wells. It is possible that the recently devised method of underground exploration based on the electric conductivity of the different rock formations can be used in finding the limits of shallow underground conduits, but that method seems not to be available for determining the permeability of different units of the cross section or the velocity of the ground water flowing through them.

The flow of a surface stream, in cubic feet per second, can be found by multiplying the average downstream component of the velocity of the water in feet per second by the area of the cross section of the stream in square feet. To determine the flow of ground water, however, a third factor, which has been called the effective

\footnotetext{
stabler, Herman, Fluorescein an aid to tracing waters underground: Reclamation Record, vol. 12, pp. 122, 123, U. S. Recl. Service, 1921.

so Stiles, C. W., Crohurst, H. R., Thomson, G. E., and Stearns, N. D., Experimental bacterial and chemical pollution of wells via ground water, with a report on the geology and ground-water hydrology of the experimental area at Fort Caswell, N. C.: U. S. Pub. Health Service Hygienic Lab. Bull. 147, 1927.
} 
porosity, must be applied. Much of the cross section is occupied by rock and by water that is securely attached to the rock surfaces by molecular attraction. The area through which the water is flowing is therefore less than the area of the cross section of the waterbearing material and may be only a small fraction of that area: In a coarse, clean gravel, which has only large interstices, the effective porosity may be virtually the same as the actual porosity, or percentage of pore space; but in a fine-grained or poorly assorted material the effect of attached water may become very great, and the effective porosity may be much less than the actual porosity. Clay may have a high porosity but may be entirely impermeable and hence have an effective porosity of zero. The effective porosity of very fine grained materials is generally not of great consequence in determinations of total flow, because in these materials the velocity is so slow that the computed flow, with any assumed effective porosity, is likely to be relatively slight or entirely negligible. The problem of determining effective porosity, as distinguished from actual porosity, is, however, important in studying the general run of water-bearing materials, which are neither extremely fine nor extremely coarse and clean.

Hitherto not much work has been done on this phase of the velocity methods of determining rate of flow. No distinction has generally been made between actual and effective porosity, and frequently a factor of $331 / 3$ per cent has been used, apparently without even making a test of the porosity. It is certain that the effective porosity of different water-bearing materials ranges between wide limits and that it must be at least roughly determined if reliable results as to rate of flow are to be obtained. It would seem that each field test of velocity should be supplemented by a laboratory test of effective porosity, for which the laboratory apparatus devised by Slichter could be used. ${ }^{90}$

Velocity methods have been used chiefly on water-bearing formations lying at or near the surface. The electrolytic method has been used chiefly to determine the underflow of streams through alluvial deposits confined in rock troughs. These tests have produced data on the velocity of ground water through materials of certain kinds and under known hydraulic gradients. The data are perhaps of the greatest value in furnishing a general comparative basis for making rough estimates of velocity of ground water in other places and under other conditions. Their value in the specific investigations for which they were made has been largely in giving negative information, for they have generally shown that the rate of under-

90 Slichter, C. S., Field measurements of the rate of movement of underground waters: U. S. Geol. Survey Water-Supply Paper 140, pp. 29-49, 1905. 
flow is small in comparison with the reeharge that occurs all along the valley by downward percolation of rain or stream water. At the present time methods to determine the rate of flow are most needed in connection with water-bearing formations which lie beneath confining beds and in which the water must travel long distances from the intake areas to the areas of recovery. One of the principal difficulties in using velocity methods on such formations is the cost of sinking the deep test wells that would generally be required.

\section{METHODS BASED ON LABORATORY DETERMINATIONS OF PERMEABILITY}

About 1843 Poiseuille, ${ }^{21}$ in connection with his studies of the circulation of the blood, discovered the law of flow through capillary tubes-namely, that the rate of flow is proportional to the hydraulic gradient. In 1856 Darcy, ${ }^{92}$ inspector general of the Paris waterworks, whose extensive and valuable experiments on the flow of water through pipes are well known, verified this law and demonstrated its application to water percolating through the capillary interstices of sand or other porous medium. He expressed this law by means of the formula $v=\frac{k p}{h}$, in which $v$ is velocity of the water through a column of permeable material, $p$ the difference in head at the two ends of the column, $h$ the length of the column, and $k$ a constant that depends on the character of the material, especially on the size of the grains, which was to be experimentally determined.

In the 75 years since the results of Darcy's work were published laboratory investigations of various phases of the problem of the flow of liquids and gases through permeable materials have been made, many of them by French and German physicists and engineers.9 A critical review of the early investigations was made by King, ${ }^{94}$ an American physicist and hydrologist. He reviewed the laboratory studies on the flow of water through permeable materials that were made by the European investigators Hagen, Seelheim, Welitschkowsky, and Wollny and by the American engineer J. C. Trautwine; the work of Thomas Graham and O. E. Meyer, who demonstrated that the law of Poiseuille holds for gases as well as for liquids; and the later investigations by Fleck, Welitschkowsky, Renk,

\footnotetext{
m Poiseullle, J., Recherches experimentales sur le mouvement des liquides dans les tubes de tres petit diametre: Mém. savants etrang., vol. 9 , p. $433,1846$.

Darcy, H. P. G., Les foptaines publiques de la ville de Dijon, Paris, 1856. See Stichter, C. S., The motions of underground waters: U. S. Geol. Survey Water-Supply Paper 67, pp. 18, 19, 1902.

See blbliography in Slichter, C. S., Theoretical investigation of the motion of ground waters: U. S. Geol. Survey Nineteenth Ann. Rept., pt. 2, pp. 380-384, 1899.

at Klng, F. H, Principles and conditions of the movements of ground water: U. 8. Geol. Survey Nineteenth Ann. Rept., pt. 2, pp. 178-189, 1899.
} 
Ammon, and Wollny concerning the flow of gases. The whole subject of the law of flow of liquids, and gases through capillary tubes and permeable materials was reinvestigated by King, and his results are given in the paper cited. During the years 1902 to 1904 laboratory experiments on the flow of water through sand and gravel were made under the direction of Slichter ${ }^{95}$ with lower hydraulic gradients than had previously been used, in order to approximate natural conditions more closely. Since that time permeability experiments with both liquids and gases have been made by other American physicists and engineers in various fields of investigation. In 1923 a hydrologic laboratory was established in the Geological Survey, and tests of permeability to water were made under hydraulic gradients as low as 5 feet to the mile. ${ }^{96}$ In this laboratory standard permeability tests under low gradients are now made of many waterbearing materials found in the areas that are investigated by the Geological Survey.

The foregoing historical review shows that Darcy's law, that the flow of water through a permeable material varies directly as the hydraulic gradient, has been thoroughly tested by experiment and has been demonstrated to be correct for practical purposes if it is not applied with excessive extrapolation. Hence, the flow through a formation can be computed if its permeability, the hydraulic gradient of the water it contains, and the area of its cross section are determined.

The hydraulic gradient can be rather satisfactorily determined by measuring the depth to the water level in wells properly distributed over the area underlain by the formation. A well should not be yielding water at the time it is measured or for some time prior to its measurement; otherwise there will be a local drawdown that will introduce an error. There may also be a drawdown caused by heavy flow or pumping from other wells in the same vicinity, and precautions must be taken with respect to errors that might be produced by changes in atmospheric pressure or other causes. The water levels are measured from definite bench marks, or reference points, to which levels are run. A contour map of the pressureindicating surface is then constructed. Such a map shows approximately the direction of movement of the ground water and the hydraulic gradient at every point, the direction in any locality being at right angles to the contour and the gradient being the ratio of the contour interval to the distance between successive contours.

The area of cross section can be estimated from well records and outcrops that show the thickness and extent of the formation. A

פ5 Slichter, C. S., Field measurements of the rate of movement of underground waters : U. S. Geol. Survey Water-Supply Paper 140, pp. 29-49, 1905.

(6) Stearns, N. D., Laboratory tests on physical properties of water-bearing materials : U. S. Geol. Survey Water-Supply Paper 596, pp. 144-163, 1927. 
cross section that is pertinent for this purpose must obviously have the same general trend as the contours of the pressure-indicating surface, in order to be approximately at right angles to the direction of flow.

The most serious difficulty with this method and one that up to the present time has not been effectively overcome is that of determining the true average permeability of the material that constitutes the water-bearing formation. Laboratory methods are available to determine accurately the permeability of the samples that are tested, but the difficulty lies in obtaining representative samples. Even apparently slight differences in texture may make great differences in permeability. A rather inconspicuous admixture of colloidal clay to an otherwise permeable sand may cut down greatly its capacity to conduct water. In a sand formation a few thin strata of coarse, clean sand may conduct more water than all the rest of the formation. These permeable strata may be overlooked in the sampling, or if samples from them are taken it may be impossible to give them the proper weight in comparison with samples from other parts of the formation. Consolidated rocks are likely to contain joints and crevices which conduct much of the water and which therefore render laboratory methods inapplicable. On the other hand, unconsolidated samples can not easily be recovered and tested without disturbing the texture of the material and thus introducing errors of unknown but conceivably great amount. Moreover, samples taken at the outcrop of a formation may not be representative because of changes produced by weathering, and samples obtained from wells are generally nonvolumetric and greatly disturbed and may be either washed or mixed with clay of foreign origin. If the conditions of drilling can be controlled it may be possible to obtain an undisturbed or only moderately disturbed sample, especially if a core barrel is used, but such favorable conditions are rarely obtainable. In spite of the difficulties, the laboratory tests are of value in giving general limits of permeability, and it will be highly desirable to complete the project, now in progress, of making a set of permeability tests of all the leading formations in this country that conduct water through their pore spaces.

Efforts have been made by Hazen, King, Slichter, and others ${ }^{87}$ to compute the permeability of water-bearing material from its mechanical composition and porosity. For this purpose Hazen, ${ }^{88}$ in his

\footnotetext{
mor a review of the work of Allen Hazen, F. H. King, and C. S. Slichter on this gubject, with references, see Stearns, N. D., op. cit., pp. 170-176.

os Han, Allen, Experiments upon the purification of sewage and water at the Lawrence Experiment Station, Nov. 1, 1889, to Dec. 31, 1891: Massachusetts Board of Health Twenty-third Ann. Rept., p. 431, 1892; Some physical properties of sands and gravels with special reference to their use in filtration: Massachusetts Board of Health Twenty. fourth Ann. Rept., p. 541, 1893.
} 
work on filter sands in 1889 to 1893 , used the term "effective size of grain," or size of grain that would give the actual permeability of a more or less heterogenous material. He found that in the materials with which he was dealing the effective size was best shown by the " 10 per cent size"- that is, the size that is not exceeded by the grains in 10 per cent of the material by weight. These indirect methods of computing permeability are useful for some purposes but have not always given consistent results and are not in general to be recommended. Direct tests of permeability require no more work and are generally more satisfactory.

\section{METHOD BASED ON PERMEABIIITY DETERMINED FROM DISCHARGE AND DRAWDOWN OF WELIS}

One of the most promising methods of determining permeability is a field method proposed by $G$. Thiem, ${ }^{99}$ son of the German hydrologist A. Thiem, based on the performance of wells that enter the water-bearing formation. In order to make a test by this method it is necessary to have one well from which water can be withdrawn, either by pumping or by artesian flow, at a rate that will produce considerable drawdown, and two or more other wells that are located at different distances from the discharge well and near enough to it to have appreciable drawdown when it is discharging. This method has the advantage over the laboratory methods in that it deals with all the water-bearing materials in the vicinity of a well, undisturbed and in place.

The method is very simple in principle. The water level is measured in each of the observation wells at a time when the discharge well has been idle long enough for the water levels to have reached the static level. The well is then pumped or allowed to discharge by artesian pressure at a uniform rate until equilibrium has again been virtually established and the new water levels have become essentially stationary. If the test is made in an area of artesian flow, the pressure may be measured instead of the depth to the water level. From the ultimate drawdown in the several observation wells produced by the pumping or artesian discharge a profile of the cone of depression can be constructed, and from this profile the hydraulic gradient at any distance from the discharge well can be determined. If the water-bearing formation is of uniform character and thickness in the vicinity of the wells and the thickness is known, all three factors are available for computing the permeability. If the water in the formation is confined under pressure, the cross-section area is obviously $2 \pi r t$, in which $r$ is the distance from the discharge well to the point where the hydraulic

*Thiem, G., Hydrologische Methoden, Leipzig, 1906. 
gradient is determined and $t$ is the thickness of the formation. If the water is not confined but forms a water table, the effective crosssection area is $2 \pi r t^{\prime}$, in which $t^{\prime}$ is the thickness of the saturated part of the formation or the height of the water table above the base of the formation during pumping at the point where the hydraulic gradient is determined. In either case the coefficient of permeability as defined in Water-Supply Paper 596 is equal to $\frac{q}{a g}$, in, which $q$ represents the rate of pumping or artesian discharge in gallons a day, $a$ the cross-section area in square feet, and $g$ the hydraulic gradient as defined on page 132. Further investigation is needed as to inaccuracies that may be introduced by irregularities in the texture, thickness, and stratigraphy of the formation, by the natural slope or irregularity of the pressure-indicating surface, and by decrease in permeability that may result from compression of the formation when the artesian pressure of the water is relieved. The permeability determined by this method is used in exactly the same manner as the permeability determined by any other method in computing the rate of flow through a formation when its crosssection area and the natural hydraulic gradient of -its water are known.

In $1906 \mathrm{G}$. Thiem published as a dissertation for the degree of doctor-engineer from the Konigliche Technische Hochschule at Stuttgart the results of his experiments and mathematical study relating to his field method for determining permeability. The experiments were made as a part of an investigation to find an additional water supply for the city of Prague. Ten sets of wells were sunk for the purpose, each set including one well that was pumped and two observation wells. The observation wells were placed in line with the pumped well but in any direction from it regardless of the direction of the natural hydraulic gradient. A formula was developed for computing the permeability from these tests. This formula, slightly modified in form, is as follows:

$$
P=\frac{\left(q \log _{e} a_{1}-\log _{e} a\right)}{2 \pi m_{1}\left(S-S_{1}\right)}
$$

in which $P$ is the coefficient of permeability, $q$ is the rate of discharge, $a$ and $a_{1}$ are the respective distances of the two observation wells from the discharge well, $S$ and $S_{1}$ are the respective drawdowns in the two observation wells, and $m$ is the thickness of the water-bearing bed, if artesian conditions exist, or the average thick: ness of the saturated part of the bed at the two observation wells, if water-table conditions exist. To obtain the coefficient of per meability as defined in Water-Supply Paper 596 all these factors should be expressed in feet except $q$, which should be expressed in gallons a day. 
Theoretically this method can also be used for computing specific yield, but no test has been made of its practicability for this purpose. For example, during a specified period in the initial stage of a test under water-table conditions an accurate record can be obtained of total pumpage and of the progressive lowering of the water levels in the observation wells. From the record of water levels and the permeability, as determined by the test, the flow through the selected cylindrical cross-section area during the period can be computed. The quantity taken from storage within the cylinder can then be computed as the total pumpage minus the inflow, and from the records of the water levels the volume of material in the cylinder that was unwatered during the period can also be computed. Better results can doubtless be obtained, however, if the specific-yield test is made during a period immediately after the well has been shut down, when the quantity of water taken into storage in the cylinder will be equal to the total inflow during the period and the volume of material saturated can be computed from the rise of the water levels.

Closely akin to the specific yield, but generally of much smaller magnitude, is the change in storage capacity of an artesian formation with changes in the artesian pressure on account of the volume elasticity of the formation. Obviously the increase in storage in an artesian formation can be computed from progressive changes in artesian pressure immediately after the discharge well has been shut down, by the procedure that has just been outlined for computing specific yield under water-table conditions. Rough computations of this kind have been made. ${ }^{1}$

\section{METHOD BASED ON AREA OF INFLUENCE OF WELLS}

Ground water obeys the law of all fluids in that it always flows away from a point of high pressure toward one of lower pressure. In other words, it flows in the direction of the hydraulic gradient. In a formation that has a water table the ground water flows from a high area of the water table toward a low area, much as surface water flows down the slope of a land surface. In an artesian formation the water flows in the direction of the hydraulic gradient; it may flow downward or upward, as in the mains and service pipes of a system of waterworks. In some places the artesian water moves in the direction of the dip of the formation, and in other places it moves in a direction opposite to the dip or at some angle to the dip. An accurate contour map of a water table or of the pressure-indicating surface of a formation filled. with water under pressure shows the direction of flow at every point.

1 Meinzer, O. E., Compressibility and elasticity of artesian aquifers : Econ. Geology, vol. 23 , pp. 263-291, 1928. 
So long as no wells have been sunk into a formation its water flows from the intake area toward the area of natural discharge. If, however, wells are sunk and water is withdrawn through them, either by pumping or by artesian flow, the water table or other pressure-indicating surface will be depressed in the vicinity of the wells, and water that would normally percolate to an area of natural discharge will be diverted toward the wells. An accurate contour map showing the depression in the pressure-indicating surface caused by the operation of the wells will show the area within which the water is diverted toward the wells.

So long as the withdrawals are relatively light the depression will remain small, and water which in its natural course does not flow near the wells will not be diverted. As the withdrawals become heavier, however, the depression is enlarged and a greater proportion of the ground water is diverted toward the wells, until eventually the depression may extend across the entire width of the formation, and practically all of the flow may be recovered through the wells.

The flow of ground water through a formation can be estimated from a record of the pumpage or artesian flow and the extent of the depression as determined from water levels in wells, due allowance being made for the quantity of water that is taken out of storage in developing the depression. This method has the advantage that it does not require determination of the permeability and involves specific yield only in so far as there is a change in storage. Except for changes in storage it involves only the rate of pumping or artesian flow and the altitude of the water levels in the observation wells. The method should prove applicable where a considerable quantity of water is withdrawn and sufficient, wells are available for waterlevel observations.

In applying this method attention must be given to the modified condition of the pressure-indicating surface on the downstream side of the depression produced by the operation of the wells. If no water is permitted to pass the wells this surface will eventually be lowered about to the level of the natural outlet of the ground water or to the level of the crest of an effective underground barrier. In many places this drawdown would make the cost of pumping prohibitive. In order to prevent the lowering of the water levels in the wells below the economic limit it may be necessary to allow a part-perhaps a large part-of the water to flow past the depression, so that it will maintain a certain minimum gradient to the natural outlet. 


\section{METHOD BASED ON MOVEMENTS ON WATER LEVFLS IN RETATION TO RATES OF WITHDRAWAL}

When a well is pumped some water is inevitably taken out of storage from the well and from the material surrounding it. This reduces the pressure, creates a hydraulic gradient toward the well, and causes the ground water to flow into the well. If the water-bearing formation has a water table, considerable ground water may have to be removed from storage before a gradient will be developed that is steep enough to make the water flow toward the well at the same rate that it is pumped and to establish approximate equilibrium. If the formation is filled with water under pressure only a comparatively small amount of water has to be removed from storage in order to give the required gradient, and hence drawdown will be rapid and approximate equilibrium will be quickly established. The quantity to be removed from storage in order to reach equilibrium varies in proportion to the compressibility of the water-bearing formation. ${ }^{2}$

When, with a constant rate of pumping, equilibrium is established, water is no longer removed from storage around the well but flows to the well as rapidly as it is withdrawn. Even after there is approximate equilibrium and the water level in the well remains virtually stationary the water may be taken from storage in distant parts of the formation rather than from the increments at its intake area. However, unless the withdrawal exceeds the recharge minus the unavoidable loss, the water level in the well will approach a limit at a constantly decreasing rate of drawdown. In most ground-water developments the supply available is conditioned by the permissible lift. A vital question, therefore, relates to the rate at which water will flow to the well under the gradient that will be established by the drawdown involved in the permissible lift.

This elementary principle of hydraulics controls not only the practicable capacity of an individual well but also the quantity of water that can be recovered by a group of wells or by a large number of wells distributed throughout a wide area. The details are more complicated, but the principle is the same. If the ground-water supply in an area is extensively developed by drilling many wells and drawing heavily on them the water levels or artesian pressures in the wells will inevitably decline. This decline will occur whether the conditions are primarily of the water-table or the artesian type, and whether the artesian wells discharge by artesian flow or by pumping. Other things being equal, however, the decline will occur more rapidly under artesian conditions than under water-table conditions. The mere fact that there is a decline in the water levels or artesian

2 Meinzer, O. D. Compressibility and elasticity of artesian aquifers: Econ. Geology, vol. 23 ; pp. 263-291, 1928. 
pressures during the period of development, when the rate of with. drawal is constantly inereasing, is not an indication of overdevelopment as long as the decline is not so great as to indicate the approach of lifts beyond the economic limit:

If the rate of pumping becomes constant the water levels in the wells will not immediately become stationary, but they will decline at a diminishing rate. If the rate of pumping exceeds the salvageable recharge the water levels will eventually decline to the bottoms of the wells, and the rate of recovery will unavoidably be decreased. If, however, the rate of pumping does not exceed the salvageable recharge, the water levels will approach as a limit some level above the bottom of the wells, though perhaps too low for practicable operation. To determine the limit even approximately requires the lapse of sufficient time to permit the development of a curve in which the water levels in a key well or group of wells are plotted against time and which can with some confidence be projected into the future. The problem will invariably be complicated by irregularities in the rate and location of the pumping, adequate records of which can not easily be obtained, and also by fluctuations in water levels produced by causes other than pumping.

In most areas there are fluctuations in the rate of pumping or of artesian flow, as the case may be. In many areas the most pronounced fluctuations are seasonal. On the whole these fluctuations increase the applicability of this method. It has been shown that some decline in. water levels must be expected even after the rate of pumping has become constant. Furthermore, decline may even continue for some time after the rate of pumping has been reduced without indicating a dangerous amount of ultimate drawdown. However, if with either constant or reduced rate of pumping the water levels continue to decline persistently and without marked slowing up, excessive ultimate drawdown is indicated, although it may not be possible to determine the ultimate drawdown or to estimate the amount of overdevelopment. In the development of many of the areas of artesian flow there is an early period of original high pressure and active drilling during which the artesian discharge increases greatly and the pressure drops rapidly. This early period is generally followed by a long period in which there is progressive but gradual decline both in discharge and in pressure. It appears obvious that nnder these conditions water is being withdrawn from storage and that equilibrium will not be established until the pressure or the discharge or both are still further reduced. ${ }^{3}$

s Meinzer, O. E., and Hard, H. A., The artesian water supply of the Dakota sandstone in North Dakota, with special reference to the Edgeley quadrangle: U. S. Geol. Survey Water-Supply Paper 520, pp. 73-95, 1926. Hard, H. A., Geology and water resources of the Edgeley and LaMoure quadrangles, N. Dak.: U. S. Geol. Survey Bull. 801, pp. 5787, 1829. 
If the rate of pumping or of artesian discharge is radically reduced, as it is in the autumn in irrigation districts and in some public waterworks, the water levels or artesian pressures that have been declining are likely to reverse their direction and begin to rise. This means that the point of equilibrium has been reached and passed-that, with the gradient which was established by the heavier withdrawal, water is flowing into the area more rapidly than it is being removed by the reduced rate of withdrawal. In the next spring or summer the rate of withdrawal may be again increased and another reversal of the water levels may occur. If the rate of withdrawal is greater than in the previous summer a new low stage may be established. By critical study of this game of tag between the water levels and the rates of withdrawal a number of points of equilibrium can be approximately determined, but exact determination is complicated by the lag in the movements of the water levels due to storage, and further study needs to be given to this subject to develop a systematic method of interpretation that is mathematically sound. These points of equilibrium are points on a rating curve of the inflowing stream of ground water. To the extent that this curve can be projected it will indicate the drawdown that will be caused by increased rates of withdrawal and will thus establish the safe yield. The rating-curve method for conduit conditions was developed by Thompson in his work in New Jersey from 1923 to 1928 and was successfully applied by him in making estimates of safe yield for Atlantic City and other municipalities. ${ }^{4}$

\section{EVALUATION OF EXTRANEOUS INFLUENCES ON THE WATER LEVELS}

The movements of the water levels in wells are not the effects of simple forces acting singly but rather the resultants of a complex of interacting forces. This complexity, of course, increases the difficulties of interpretation. For example, a study of the effects produced by different rates of pumping may be complicated through changes produced by variations in atmospheric pressure or by the ebbing and flowing of oceanic tides. The barometric or tidal effects must be evaluated, and corrections must then be made for them. These extraneous agencies are, however, not wholly a detriment, for if they are studied in a time and place where other agencies are absent or can be eliminated, they are likely to afford valuable information on the ground-water conditions.

If a shallow well ends in a formation that lies at the surface and is freely permeable throughout, only slight barometric effects or

4 Thompson, D. G., Ground-water supplies in the Atlantic City region: New Jersey Dept. Conservation and Development Bull. 30, pp. 35-88, 1928. 
none: at all are to be expected, because any change in the atmospheric pressure is transmitted almost as freely to the water table through the permeable material as to the water level in the well. In the Escalante Valley investigation, by * White, water-stage reeorders were used on about 70 shallow water-table wells. With few exceptions, the records of these wells showed no evidence of fluctuations due to changes in atmospheric pressure. The exceptions occurred chiefly in the early spring, when aparently the soil was wet enough to be impervious to air. Similarly, in a shallow observation well near Washington, D. C., barometric fluctuations, amounting to about 20 per cent of the full fluctuations of a water: barometer, are apparently confined to periods when the water in the soil tends to reduce notably its permeability to the air. Barometric fluctuations have been found to be virtually absent in observation wells equipped with automatic recorders in different parts of the country where water-table conditions exist.

If a well ends in an artesian formation and this formation or the overlying confining beds have sufficient strength to resist deformation by slight changes in pressure at the surface, the well will act as a barometer. The fluctuations of its water level will have virtually. the same range of fluctuations as would be shown by a water barometer, or 13.5 times the range in a mercury barometer. However, for obvious reasons, the movements of the water level in the well will always be in the opposite direction from those in an ordinary mercury barometer. In a deep well at The Dalles, Oreg., that ends in an artesian stratum in volcanic rocks, the water level was found by Piper ${ }^{5}$ to respond practically 100 per cent to changes in atmospheric pressure as indicated by the barographic records of the United States Weather Bureau. The record of a deep well in the Roswell artesian basin, New Mexico, obtained by means of a waterstage recorder, showed that on certain days when no great disturbances were caused by pumping the fluctuations of the water level in the well closely followed the fluctuations of the barometer. In general an inch of change in the mercury barometer was represented by about a foot of fluctuation in the water level. ${ }^{6}$ In another artesian well situated near the railroad in the same basin no rise in the water level was recorded when trains passed. Both of these results indicated artesian conditions in competent formations. If a similar well were situated near the seashore its water level would not be expected to show any tidal influence.

- Piper, A. M., Geology and ground-water resources of the Dalles region, Oregon: U. S. Dept. Interior Press Mem. 52343, Apr. 7, 1931.

- Fedler, A. G., Report on investigations of the Roswell artesian basin, New Mexieo, during the year ending June 30, 1926: New Mexico State Engineer Seventh Blenn. Rept., p. 37, pl. 7, 1926. 
If a well ends in an artesian formation that has volume elasticity, such as incoherent sand, and is confined beneath beds of soft shale that is impermeable but yields to even slight pressure, its water level will have smaller fluctuations resulting from atmospheric changas than that of a water barometer, and the ratio of the movements in the well to the corresponding movements in the barometer should give a measure of the resistance of the water-bearing and confining beds. If such a well is near the seashore its water level will fluctuate more or less with the tide. In the Atlantic City investigation, by Thompson, it was found that artesian wells near the seashore ending in Coastal Plain deposits of sand overlain by clay fluctuatel notably with the tide but showed no marked barometric fluctuations. These results seem to indicate artesian conditions in incompetent strata. In such wells the water level might be expected to rise os a result of the compression produced by a passing railroad train. In the Mokelumne area it was found that the water level in a well drilled through valley fill to a stratum at some depth below the water table rose whenever a train passed over the railroad 117 fegt away, but in a well drilled only to the water table at the same place the water level was not affected by passing trains. ${ }^{7}$

If a well ends in a formation that is effectively covered by ap impermeable bed but is unsaturated in its upper part, thus having an air chamber between the water table and the overlying impenmeable bed, and if the well is tightly cased to a level below the water table, the water level in the well will behave like that in an artesian well in competent beds. It will fluctuate through about the same range as the water level in a water barometer, because, as in the other case, the counter pressure will remain nearly constant. These conditions were noted by Thompson ${ }^{8}$ in the Grand Prairie region of Arkansas, where some of the wells were found to perform as perfect barometers, apparently with 100 per cent of barometric fluctuation. These are examples of actual conditions which have been encountered in quantitative ground-water investigations and which must be understood if the data on water levels are to be correctly interpreted.

\section{PRESENT STATUS AND OUTLOOK}

The foregoing discussion shows that there are many ways in which the problem of available supplies of ground water can be attacked, but it also shows that the subject is complicated and that

? Stearns, H. T., Robinson, T. W., and Taylor, G. H., Geology and water resources of the Mokelumne area, California : U. S. Geol. Survey Water-Supply Paper 619, pp. 148, 149, 1930.

8 Thompson, D. G., Ground-water supplies for rice irrigation in the Grand Prairle region, Arkansas: U. S. Dept. Interior Press Mem. 49844, pp. 8, 9, Jan. 26, 1931. 
there are difficulties in applying any of the methods that have been outlined. Only those who have worked on ground-vater problems can appreciate how numerous and baffing are these difficulties. No one method is applicable to all conditions. In some areas. several more or less independent methods can be used which serve to give checks on the accuracy of the work. In other areas only a single method may be applicable, or it may be almost impossible to make effective use of any of the known methods.

Other methods must be used in humid than in arid regions, in areas of large ground-water developments than in undeveloped areas, and in artesian areas than in areas with water-table conditions. Arid regions are, as a rule, better adapted for quantitative studies than humid regions, and many of the available methods have been developed in arid regions. More methods are available in developed than in undeveloped areas, and the demand for quantitative work commonly comes after there has been enough development to cause considerable drawdown. A number of the methods, however, do not depend at all on development, and considerable successful quantitative work has been done in areas that were virtually undeveloped. In the past most of the quantitative work has been done in areas in which the conditions are dominantly of the water-table or reservoir type, but recently quantitative attacks have been made on a number of artesian basins in which the capacity of the formation as a conduit is important, and methods are being developed for these conditions.

The most formidable difficulties result from the complexity of the texture of the water-bearing formations, which make it hard to get reliable figures for their two properties of chief significancespecific yield and permeability. Some of the most promising methods are those which do not involve either of these properties or else determine them from water levels in wells or from water levels and pumpage.

It is becoming evident that the chief instrument of precision in ground-water hydrology is the water-stage recorder installed over a well. The water levels in wells are sensitive to every change that takes place in the ground water, and they can be almost perfectly recorded by a high-grade automatic recorder. In the interpretation of such records lie possibilities of a new and fruitful phase of ground-water hydrology that are not now fully appreciated and that can be realized only as a result of much critical investigation. It will be necessary to understand the various agencies that influence the delicate equilibrium that exists in every body of ground water and also the nature of the container that holds the ground water and how it can be expected to respond to these agencies. It 
will be necessary to recognize clearly the basic distinctions between a water table and the pressure-indicating surface of an artesian formation, and between changes that represent increments to or withdrawals from storage and those that represent only variations in pressure.

It is also becoming evident that time is required to obtain reliable results in most quantitative investigations of ground water. In this respect ground-water work differs from most other geologic work. It does not deal primarily with features which are the fossilized product of events that occurred in past ages and which can be observed and studied at any convenient time, but it deals rather with forces that are now operating and producing changes which can be kept under observation. Past changes that were not recorded are gone forever; future changes can be observed only with the lapse of time. For this reason systematic observations should be made and records kept in every area in which large ground-water developments have been made or are contemplated, so that reliable data will accumulate and will be available for interpretation in the future: 
QUALITY OF WATER OF THE COLORADO RIVER IN 1928-1980

\author{
By C. S. Howard
}

\title{
SAMPLES
}

This report gives the results obtained in the continuation of a study of the Colorado River begun in $1925 .^{1} \quad$ The analyses represent composites of daily samples collected by the observers at the gaging stations on the Colorado River at Cisco, Utah, and Lees Ferry and Grand Canyon, Ariz.; on the Green River at Green River, Utah; and on the San Juan River near Bluff, Utah. Analyses are given for samples collected about once a month from the Williams River at Planet, Ariz. The Arizona stations are operated under the direction of W. E. Dickinson, district engineer of the Geological Survey at Tucson, Ariz., and the Utah stations under the direction of A. B. Purton, district engineer of the Geological Survey at Salt Lake City, Utah. The average discharges given in Table 3 were calculated from data furnished by these district engineers. Complete discharge data for this period will be published in the regular series of watersupply papers.

The samples were collected at Cisco by Dan Granell, A. J. Clark, and B. M. Tanner; at Lees Ferry by O. R. Clark, J. S. Gatewood, and M. B. Scott; at Grand Canyon by Charles Wells, D. H. Barber, and D. D. Lewis; at Green River by H. T. Howland and F. N. Hansen; on the San Juan River by J. A. Allis, N. D. Nevills, and J. E. Ringwood; and on the Williams River by H. S. Leak. The points at which samples were taken are shown in Figure 18.

All the samples were collected in 4-ounce bottles and were sent to the laboratory in Washington for analysis. As a rule a single bottle was filled each day. It is believed that the samples truly represented the river as to its content of dissolved mineral matter.

\section{METHODS OF ANALYGIS}

The analyses were made by the methods regularly used in the United States Geological Survey. ${ }^{2}$ The 4-ounce samples were allowed

1 Collins, W. D., and Howard, C. S., Quality of water of Colorado River in 1925-26: U. 8. Geol. Survey Water-fupply Paper 596, pp. 33-43, 1828. Howard, O. S., Quality of water of the Colorado River in 19261928: U. S. Ceeol. Surves Water-Supply Paper 636, pp. 1-14, 1929.

Collins, W. D., Notes on practical water analysis: U. B. Geol. Survey Water-Supply Paper 496, pp. 235-261, 1028, 
to stand in the laboratory until the suspended matter settled, leaving the liquid above apparently free from even traces of silt. The clear liquid was drawn off through a siphon without disturbing the sediment and was collected in flasks to make three composite samples each month.

For most of the samples the weight of the suspended material in each bottle was determined. The suspended matter was washed into an evaporating dish with distilled water and dried on a steam bath.

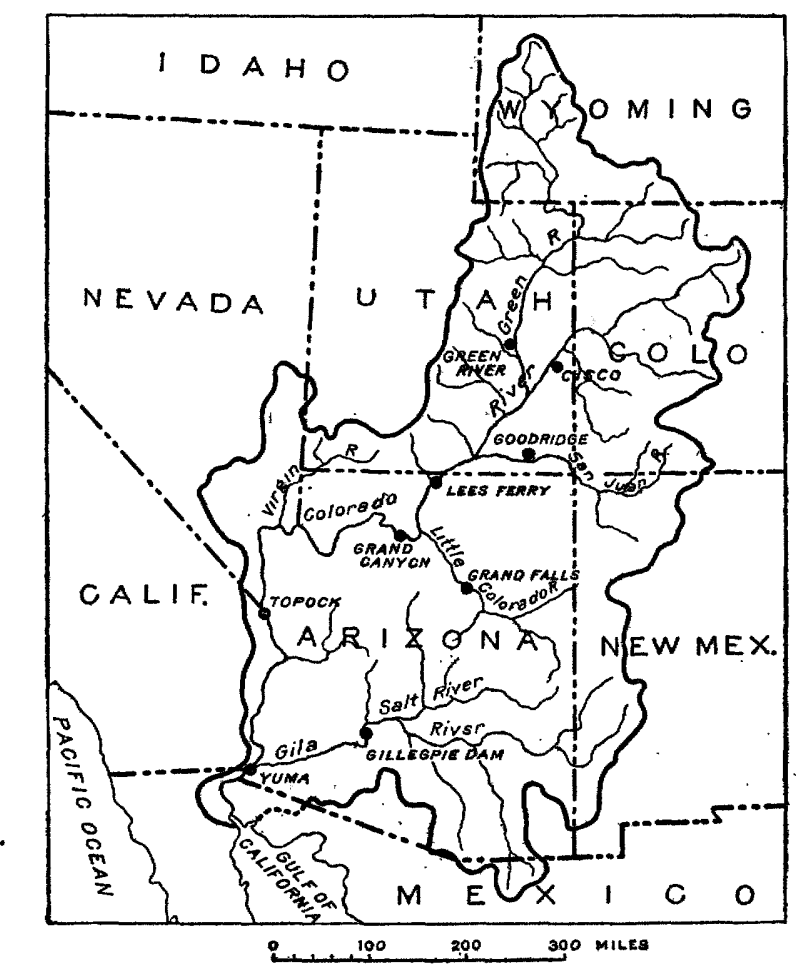

FroURE 18.-Map of the Colorado River drainage basin, showing sampling points

Correction was made for the weight of the soluble salts in the original water (usually 5 to 8 cubic centimeters) transferred to the evaporating dish with the suspended matter. The quantities of suspended matter reported for composite samples are averages of the determinations for the daily samples.

\section{COMPOSITION OF WATER OF COLORADO RIVER AND TRIBUTARIES}

Table 3 gives analyses of samples collected from the Colorado River and some of its tributaries during the period of two years. The dates show the number of daily samples in each composite. The 
plan was to have a single bottle filled each day except for the Willitims River, for which a set of eight bottles was filled about once a month. Some of the samples were lost in transit, and a few that contained hydrogen sulphide when received were rejected.

The results for dissolved solids are sums of the constituents determined, with the bicarbonate divided by 2.03 to obtain the equivalent carbonate. The total hardness is the calcium carbonate equivalent to the calcium and magnesium together. The noncarbonate hardness is the total hardness minus the quantity of calcium carbonate equivalent to the bicarbonate. The mean discharge is that for the period represented by each composite analysis. The quantity of dissolved solids in tons per day is obtained by multiplying the dissolved solids in parts per million by the discharge in second-feet and the factor 0.002697 .

The average of the 36 analyses for a year at each of the stations is given in the table:as Nos. 37, 75, 113, 151, 189, and 227. These analyses represent accurately the composition of water that would be contained in a vessel or reservoir that had received equal quantities of water from the river each day for the sampling period.

The weighted averages for each station are given as Nos. 38, 76, $114,152,190$, and 228 . The quantities of the individual constituents in each analysis were multiplied by the mean discharge for the period represented by the analysis, and the sum of the 36 products for each constituent was divided by the sum of the discharges to obtain the weighted averages. These analyses represent approximately the composition of water that would be found in a reservoir containing all the water passing the given station during the year, after thorough mixing in the reservoir. Because the composite samples for analysis were made from equal daily samples, the analyses themselves do not represent accurately the water that would be found in a reservoir containing the whole flow of the river covered by the individual analyses. The error due to this effect is not great, but its tendency is to make the weighted average show more dissolved material than would be found in the water of a reservoir storing the whole flow of the river for a year. The weighted everage shows less concentrated water than that represented by the average of the 36 individual analyses, because at times of high discharge the rivers carry the smallest amount of dissolved solids in parts per million. 
TABLE 1.-Weighted averages of analyses from Colorado River and certain tributaries for the year ending September 30, 1930

[Analytical results in parts per million]

\begin{tabular}{|c|c|c|c|c|c|}
\hline • & $\begin{array}{c}\text { Green } \\
\text { River } \\
\text { at Green } \\
\text { River, } \\
\text { Utah }\end{array}$ & $\begin{array}{c}\text { San Juan } \\
\text { River at } \\
\text { Goodridge, } \\
\text { Utah }\end{array}$ & $\begin{array}{c}\text { Colorado } \\
\text { River at } \\
\text { Cisco, } \\
\text { Utah }\end{array}$ & $\begin{array}{c}\text { Colorado } \\
\text { River at } \\
\text { Lees Ferry, } \\
\text { Ariz. }\end{array}$ & $\begin{array}{c}\text { Colorado } \\
\text { River at } \\
\text { Crand } \\
\text { Canyon, } \\
\text { Aris. }\end{array}$ \\
\hline 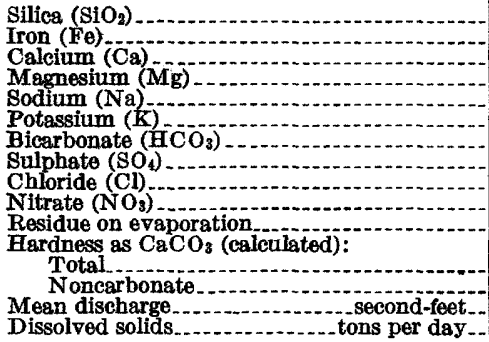 & $\begin{array}{l}14 \\
59 \\
23 \\
56 \\
3.8 \\
179 \\
177 \\
26 \\
1.2 \\
464 \\
240 \\
83 \\
6,290 \\
7,630\end{array}$ & $\begin{array}{l}16 \\
75 \\
17 \\
50 \\
3.5 \\
159 \\
214 \\
11 \\
1.7 \\
483 \\
257 \\
127 \\
2,380 \\
2,990\end{array}$ & $\begin{array}{c}14 \\
73 \\
.14 \\
28 \\
80 \\
4.4 \\
156 \\
254 \\
55 \\
6.1 \\
619 \\
298 \\
169 \\
8,420 \\
13,500\end{array}$ & $\begin{array}{c}15 \\
76 \\
25 \\
25 \\
74 \\
4.3 \\
167 \\
247 \\
44 \\
2.5 \\
597 \\
295 \\
157 \\
18,000 \\
27,800\end{array}$ & $\begin{array}{c}{ }^{16} .11 \\
81 \\
26 \\
85 \\
5.0 \\
184 \\
252 \\
62 \\
3.4 \\
645 \\
\\
311 \\
160 \\
18,500 \\
31,100\end{array}$ \\
\hline
\end{tabular}

The weighted averages for the different stations given in Table 1 show a general similarity in composition of the waters at the different stations. The increase of about 50 parts per million of dissolved material shown for the Colorado River between Lees Ferry and Grand Canyon is made up largely of sodium, chloride, and bicarbonate.

The quantity of dissolved solids carried by the Colorado River at Lees Ferry is slightly greater than the sum of the quantities carried by the three tributaries above Lees Ferry. This difference is shown graphically in Figure 19, where the quantities of each constituent are represented in ton equivalents of the average daily load.

Weighted averages for the Grand Canyon station for each of the five years and for the whole period are given in Table 2 . It will be seen that the average daily load of dissolved solids is not directly related to the mean discharge and that the maximum and minimum results for the average residue on evaporation do not occur in the same years as the maximum and minimum discharge.

TABLE 2.-Weighted averages of analyses from Colorado River at Grand Canyon for the five years ending September 30, 1930

[Analytical results in parts per million]

\begin{tabular}{|c|c|c|c|c|c|c|}
\hline & $\begin{array}{c}\text { Oct. } 9,1925 \\
\text { to Sept. } \\
30,1926\end{array}$ & $\begin{array}{l}\text { Oct. 1, 1926, } \\
\text { to Sept. } \\
30,1927\end{array}$ & $\mid \begin{array}{c}\text { Oct. } 1,1927 \\
\text { to Sept. } \\
30,1928\end{array}$ & $\begin{array}{l}\text { Oct. 1, 1928, } \\
\text { to 8ept. } \\
30,1929\end{array}$ & $\mid \begin{array}{c}\text { Oct. 1, 1929, } \\
\text { to Sept. } \\
30,1930\end{array}$ & $\begin{array}{c}5 \text {-year } \\
\text { poriod } \\
1925-1930\end{array}$ \\
\hline $\begin{array}{l}\text { Silica }\left(\mathrm{SiO}_{2}\right) \\
\text { Iron }(\mathrm{Fe})\end{array}$ & & 17.24 & 17 & 18 & 16.11 & 17 \\
\hline $\begin{array}{l}\text { Fron (Fe) } \\
\text { Calcium (Ca) }\end{array}$ & $66^{\circ}$ & $77^{-24}$ & $66^{\circ}$ & $74^{\circ}$ & $81^{.11}$ & $73^{\circ}$ \\
\hline Magnesium $(\mathrm{Mg})$ & 21 & 22 & $\begin{array}{l}22 \\
65\end{array}$ & 23 & $\begin{array}{l}26 \\
85\end{array}$ & 23 \\
\hline Potassium $(\mathrm{K})$ & 5.7 & 5.5 & 4.3 & 6.2 & 5.0 & .4 \\
\hline $\begin{array}{l}\text { Bicarbonate (HCO }{ }_{3} \text { ) } \\
\text { Sulphate (SO }\end{array}$ & 159 & 162 & 162 & 164 & 184 & 165 \\
\hline Chloride (Cl) - & 56 & 53 & 48 & 48 & 62 & 53 \\
\hline $\begin{array}{l}\text { Nitrate }\left(\mathrm{NO}_{3}\right) \\
\text { Residue on evaporation. }\end{array}$ & 1.6 & 2.4 & 2.4 & 2.5 & 3.4 & 2.4 \\
\hline Hardness as CaCo (calculated): & & & & & & \\
\hline Total & 251 & $\begin{array}{l}285 \\
152\end{array}$ & 254 & 281 & 311 & 274 \\
\hline Mean discharge & 19,900 & 23,800 & 22,200 & 26,800 & 18,500 & 21,800 \\
\hline Dissolved so & & & 29,400 & 40,100 & 31,100 & 33,100 \\
\hline
\end{tabular}


The analyses for the Williams River show bicarbonate as the prin, cipal acid constituent; in the Colorado, Green, and San Juan River sulphate is the principal acid constituent. The discharge of the Williams River is so small that the chemical composition of the Colorado River at Yuma below the Williams is practically the same as at Topock, which is above the Williams. ${ }^{3}$

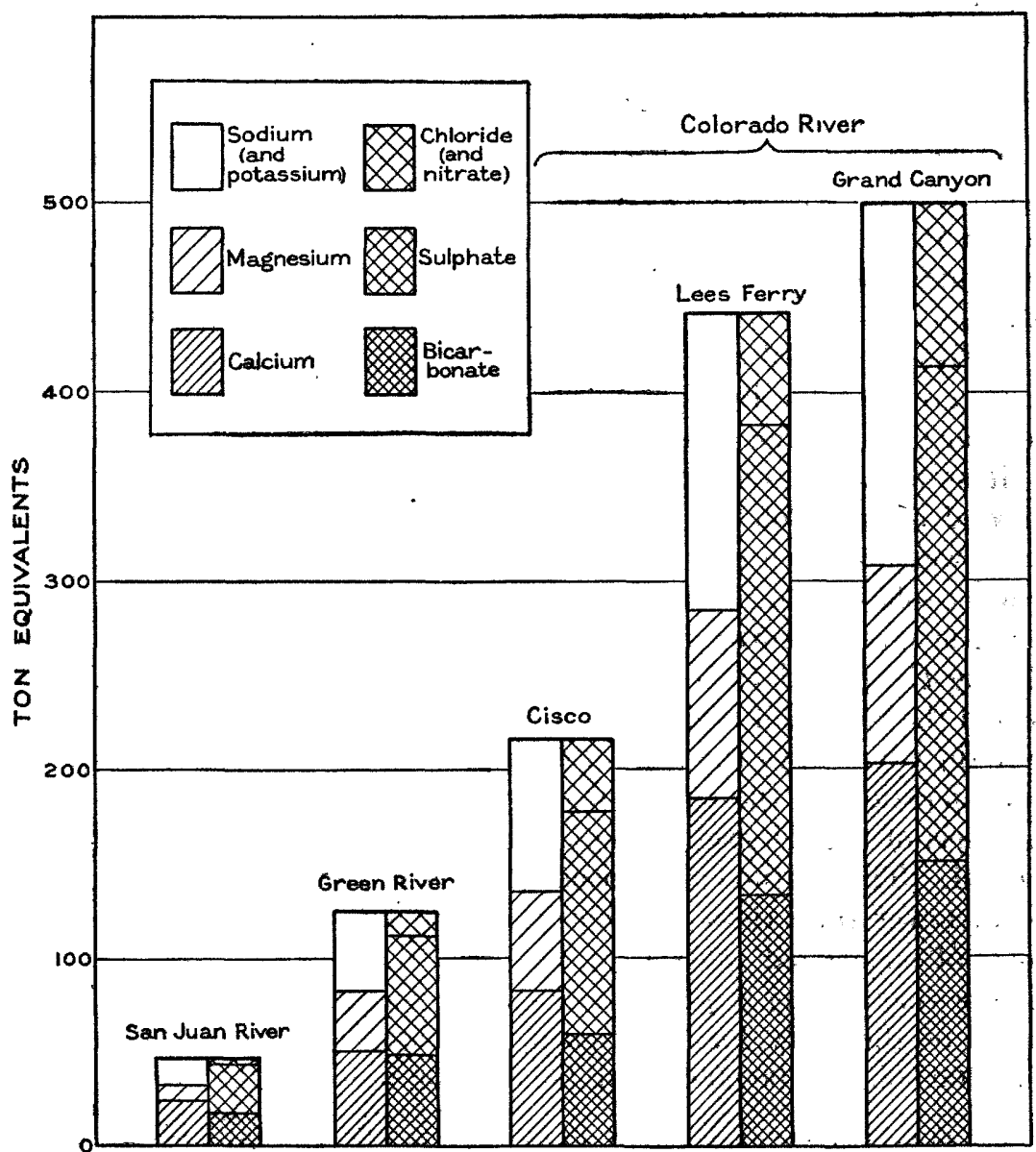

FIGURE 19.-A Aerage daily load of dissolved matter carried by the Colorado River and its principal tributaries

\section{UTILIZATION OF THE WATER OF COLORADO RIVER AND ITS TRIBUTARIES}

The water of the Colorado River and its tributaries is nearly always turbid but when clarified is satisfactory for drinking. The water is suitable for all ordinary domestic uses but is harder than is usually

\footnotetext{
${ }^{3}$ Howard, C. 8., Quality of water of the Colorado River in 1926-1928: U. S. Geol. Survey Water-Supply Paper 636, pp. 4-5, Trble 2, 1930.
} 
considered satisfactory for public supplies. Water from the Green River at Green River, Utah, and from the Colorado River at Cisco, Utah, is used in locomotives after treatment.

The usefulness of the water of the Colorado and its tributaries for irrigation is wholly dependent on the drainage of the irrigated land. With good drainage and liberal use of the water no trouble should be experienced from the ordinary constituents of the water. Without adequate drainage the soil may be seriously damaged.

\section{SUSPENDED MATTER}

The figures for suspended matter given in the table of analyses are accurate for the samples received. The samples, however, were taken at convenient sampling points and do not represent accurately the quantity of suspended matter being carried by the river. Other samples collected for a study of the silt problem indicate that the quantities reported in this table are probably low, but the determinations : are of value in indicating the quantities carried on days when regular silt samples were not taken.

Reiults have been reported ${ }^{4}$ for the quantity of suspended matter carried by the Colorado River in 1925-1928. They were computed from weighted averages of results for samples collected several times a week solely for measurement of the silt content. In order to obtain morei accurate figures daily loads have been calculated for each day during the period 1926-1930. For days when silt samples were collected the results of their examination were used to calculate the load. For the other days the load of suspended matter was estimated from consideration of the suspended matter in the samples collected for analysis of the mineral content, together with discharge data for the period. This method gives results for the annual loads that are somewhat lower than those previously reported. ${ }^{5}$ The weighted average load of suspended matter carried past the Grand Canyon station in the year ending September 30,1926 , was $225,000,000$ tons. The sums of the daily loads for each succeeding year were $396,000,000$, $172,000,000,480,000,000$, and $236,000,000$ tons respectively.

\footnotetext{
4 Howard, C. S., Suspended matter in the Colorado River in 1925-1928: U. S. Geol. Burvey Water-Supply Paper 636, pp. 15-14, 1930.

Idem, p. 24.
} 
QUALITY OF WATHR OF COLORADO RIVHR, 1928 -1890

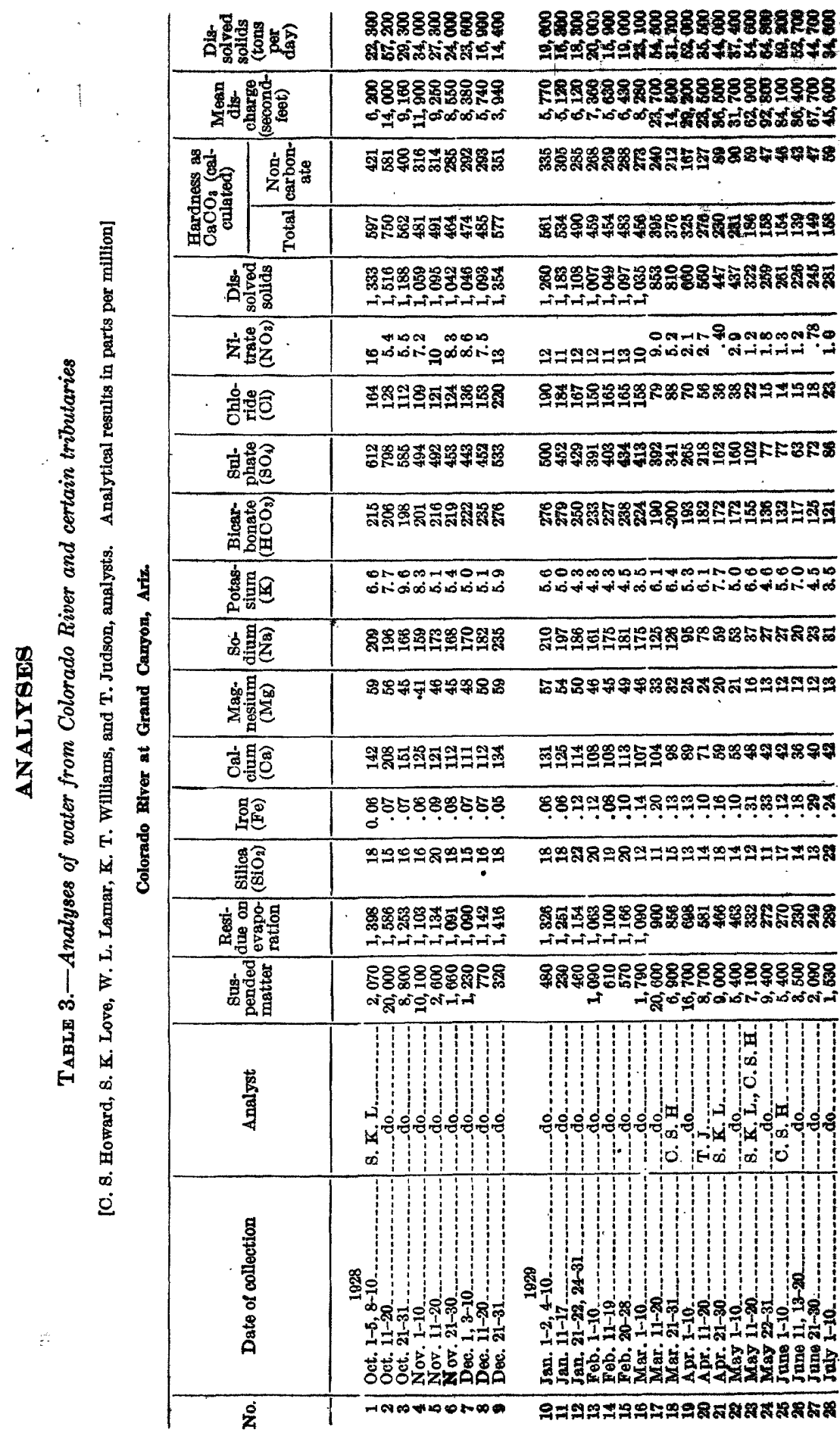




\begin{tabular}{|c|c|c|c|}
\hline & 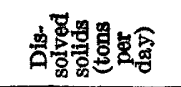 & 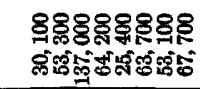 & 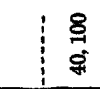 \\
\hline & 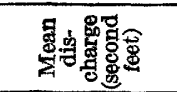 & 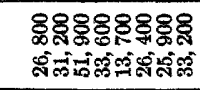 & $\begin{array}{l}8 \\
0 \\
8 \\
8 \\
\end{array}$ \\
\hline & \multirow{2}{*}{ 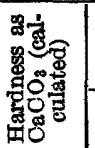 } & క్తిర్తిన్ & สำ \\
\hline & & 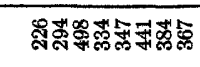 & 喿 $\bar{\AA}$ \\
\hline & 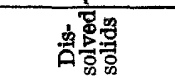 & హ゙ & 范㽞 \\
\hline & 芸造总 & สై & is \\
\hline & ㅎํㅇ휴를 & 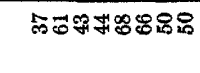 & $\% \%$ \\
\hline & 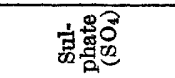 & 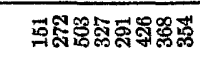 & 品 สำ \\
\hline 急 & 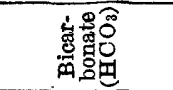 & 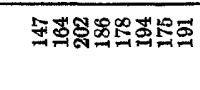 & $\stackrel{\sharp}{*}$ \\
\hline 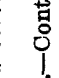 & 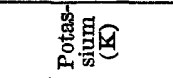 & 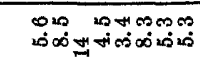 & की \\
\hline 党 & 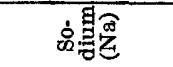 & 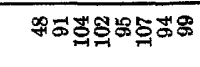 & สี \\
\hline 密 & 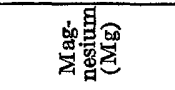 & 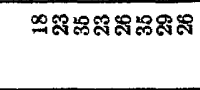 & .48 \\
\hline 댕 & 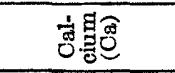 & 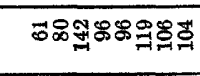 & タ だ \\
\hline 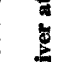 & 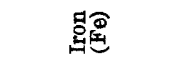 & 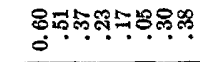 & $\fallingdotseq$ ษั \\
\hline 욜 & 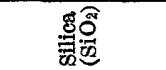 & สุニ & $\stackrel{\infty}{=}$ \\
\hline 8 & 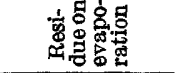 & 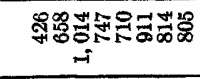 & 蛋 \\
\hline & 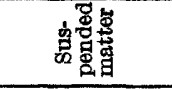 & 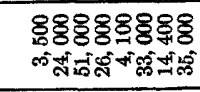 & $\begin{array}{l}8 \\
8 \\
\text { s } \\
0\end{array}$ \\
\hline | & 嵑 & 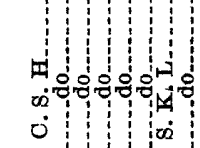 & \\
\hline & 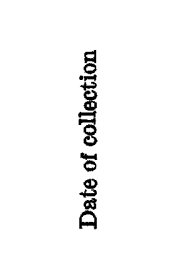 & 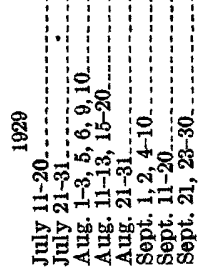 & 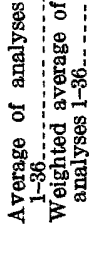 \\
\hline & 2 & 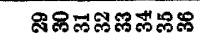 & 帛 \\
\hline
\end{tabular}

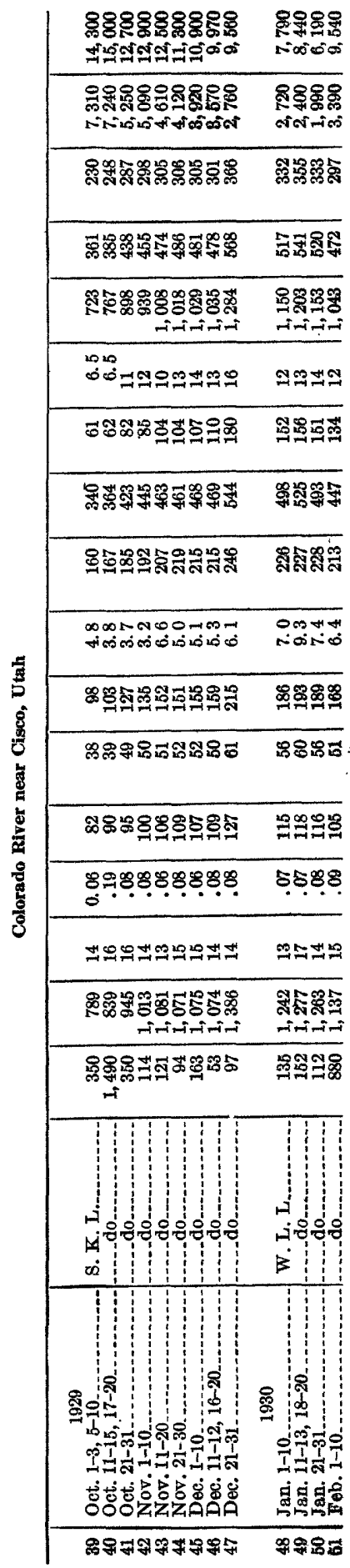




\begin{tabular}{|c|c|}
\hline 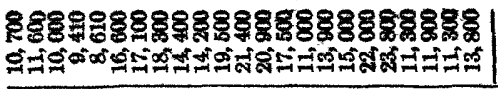 & 8 \\
\hline 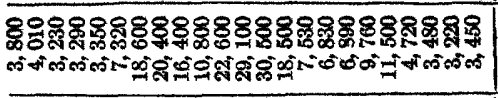 & \& \\
\hline 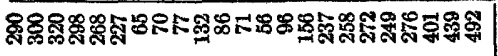 & 照 9 \\
\hline 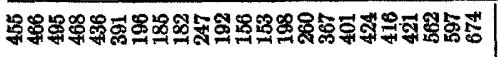 & 梁 \\
\hline 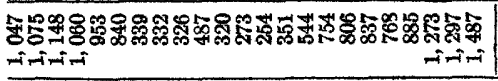 & 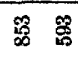 \\
\hline 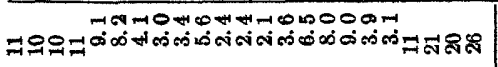 & $\stackrel{\circ}{\circ} \dot{0}$ \\
\hline 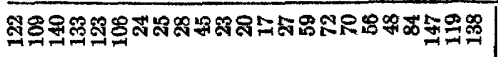 & 8 : \\
\hline 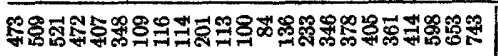 & : \\
\hline 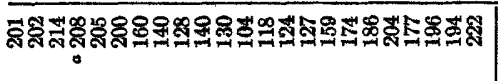 & $\stackrel{\circ}{\circledR}$ \\
\hline 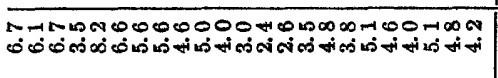 & is \\
\hline 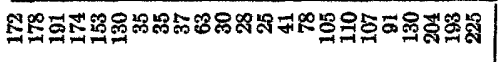 & స \\
\hline 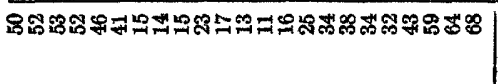 & $\exists \not$ \\
\hline 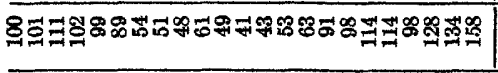 & का \\
\hline 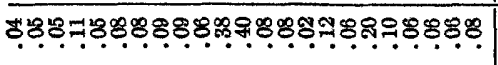 & $\because$ \\
\hline
\end{tabular}

\begin{tabular}{|c|c|}
\hline 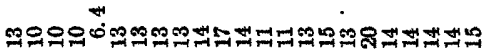 & $\mathbb{H}$ \\
\hline 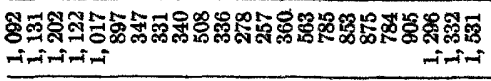 & 品 옳 \\
\hline 역율유. & $\begin{array}{c}8 \\
\substack{\mathscr{W} \\
\text { ri }}\end{array}$ \\
\hline
\end{tabular}

ó ó

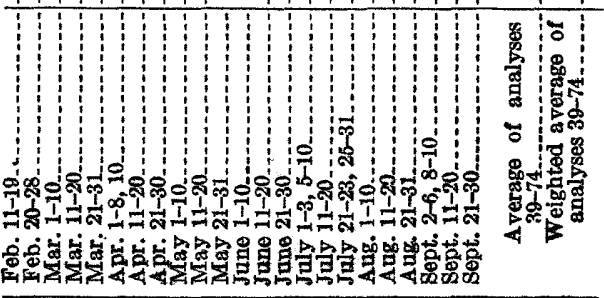

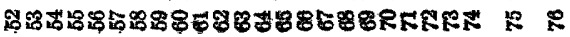

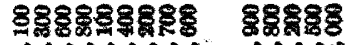

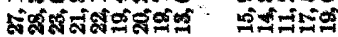

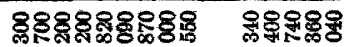

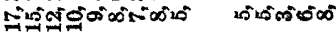

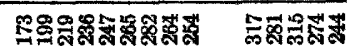

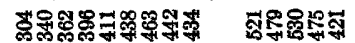

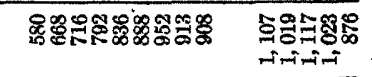

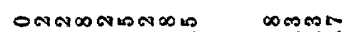

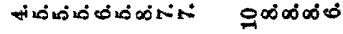

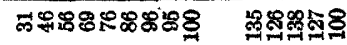

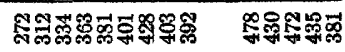

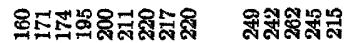

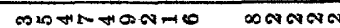

सं का

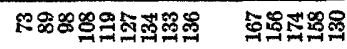

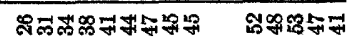

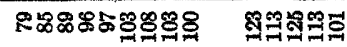

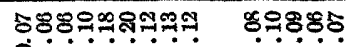

00

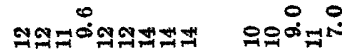

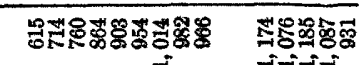

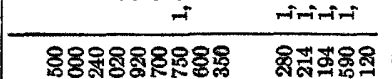

कलेंते

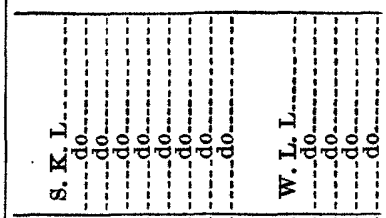

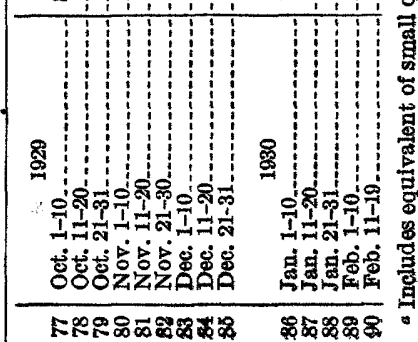


CONTRIBUTIONS TO HYPROLOGY OF UNITED STATES, 1931

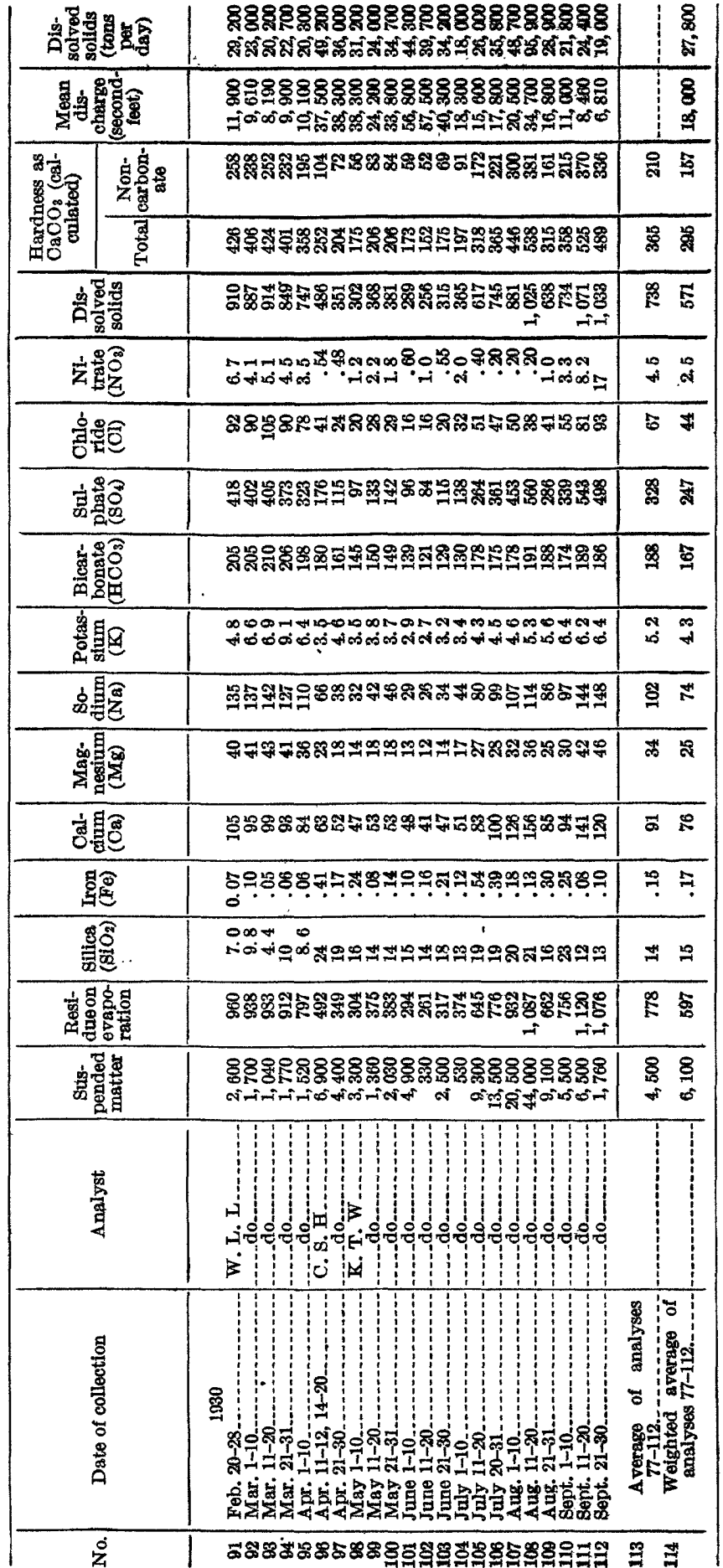


QUALITY OF WATER OF COLORADO RIVER, 1928-1930

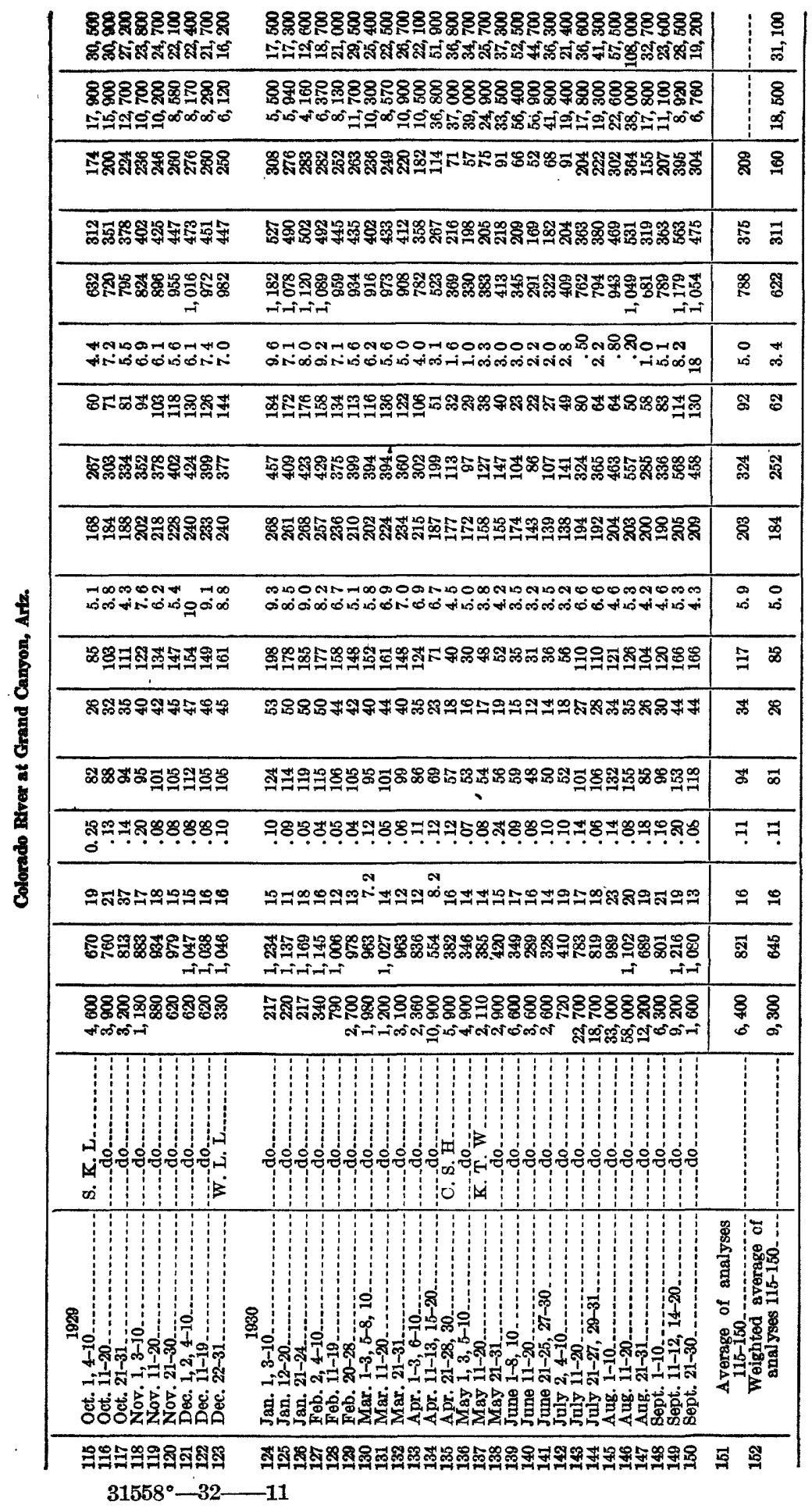




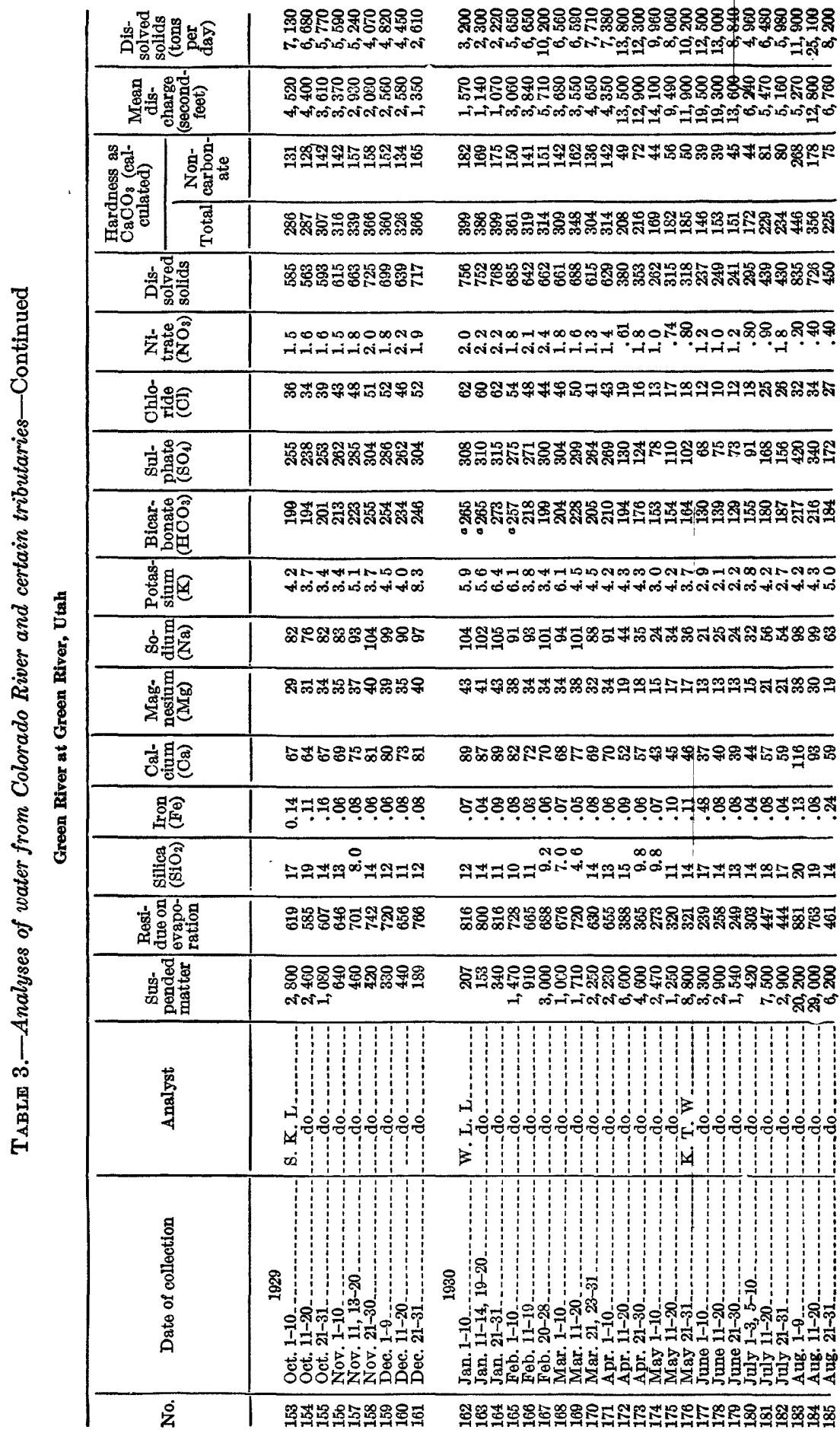




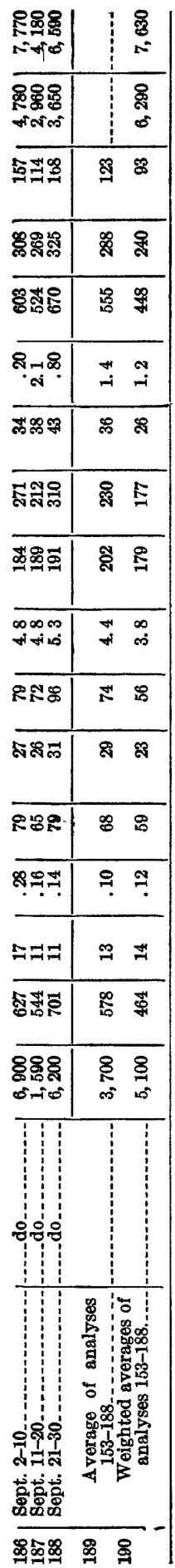

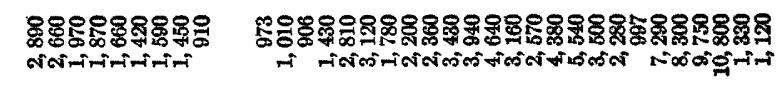

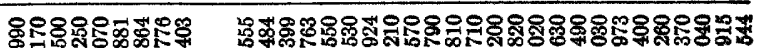

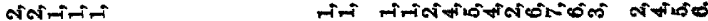

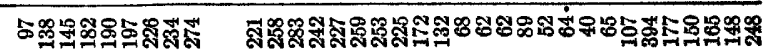

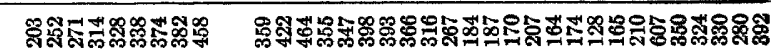

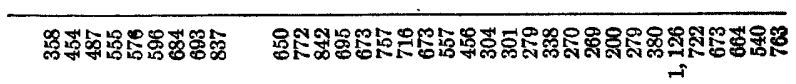

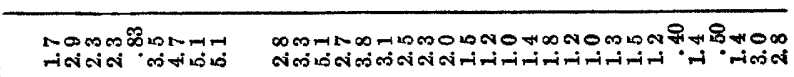

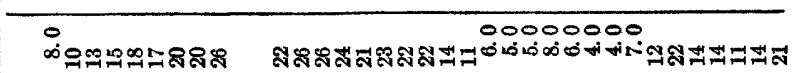

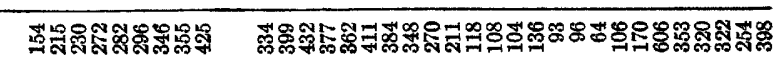

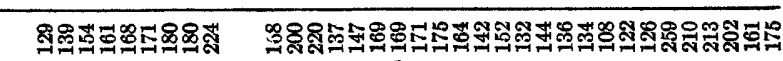
-

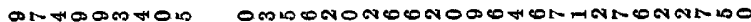

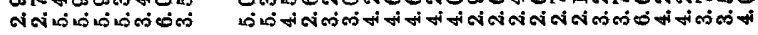

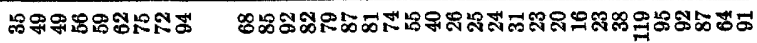

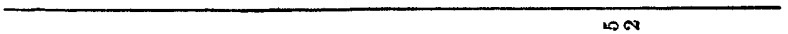

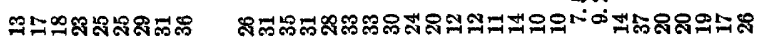

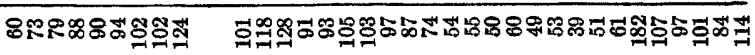

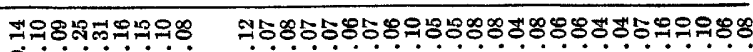

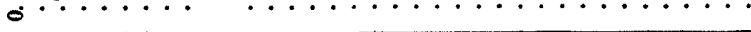

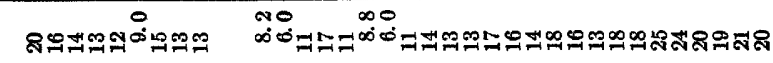

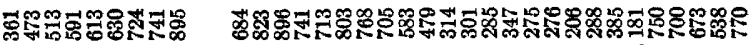

10

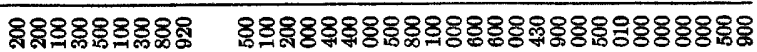

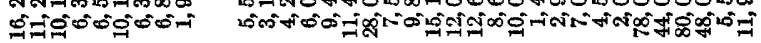

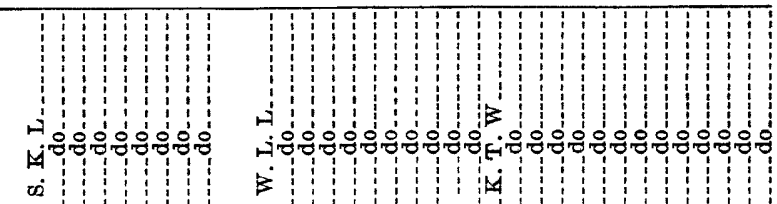

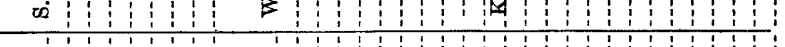

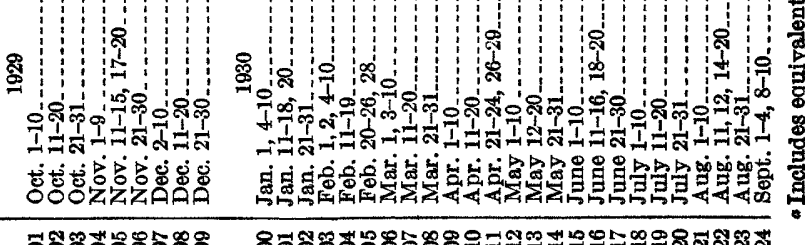

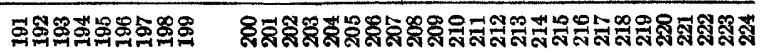




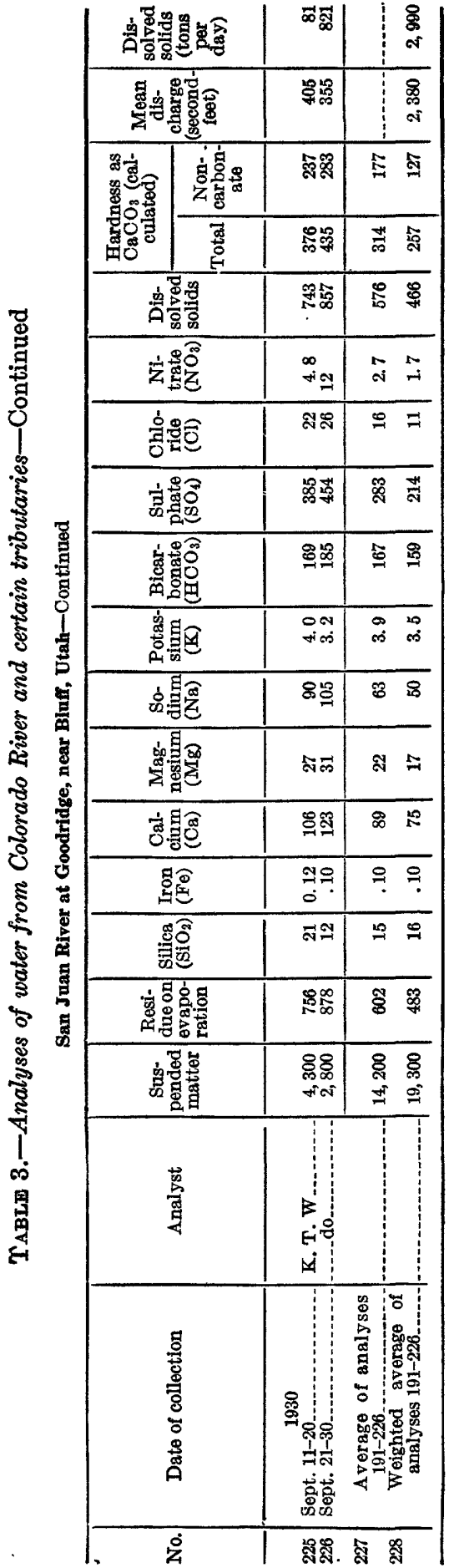

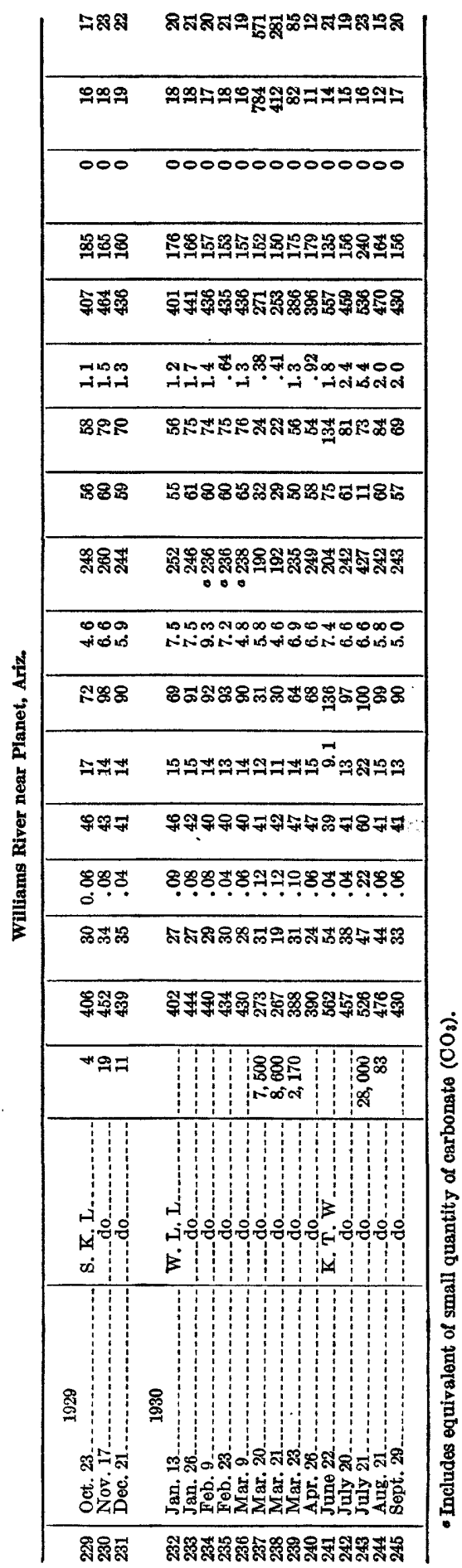




\section{INDEX}

$A$

Abstracts of reports

Ackerman formation, occurrence and char-

acter of.

Acknowledgments for aid

$1-2,40$

Ament Dam, Oreg., view of . ................... pl. 20

Ament power site, Oreg., drainage area and estimated discharge at

general features of.

$83-84$

Analysis of water, methods of

$145-146$

Applegate reservoir site, Oreg., general features of.

$62-64$

Applegate River, Oreg., dam site on, view of. pl. 15

summary of results from storage on ......- 66

Ashland power plant, Oreg., general features of

view of. pl. 18

Atlantic City, N. J., investigations of ground water at........................ 140, 142

Atmospheric pressure, effects of, on water levels in wells.................... 140-142

Auction Avenue well, altitude of water level in. $22,25-27, \mathrm{pl} .2$

\section{B}

Bald Mountain power site, Oreg., drainage area and estimated discharge at

general features of

Bluff, Utah, analyses of water of San Juan River, near.

Bolivar, Tenn., analyses of water from well at.

rainfall at 23, pl. 2

Butte Creek dam site, Oreg., view of pl. 19

Butte Creek power site, Oreg., drainage area and estimated discharge at.......

general features of.

Butte Falls power plant, Oreg., general features of. 77-78

\section{0}

Cascade power site, Oreg., drainage area and estimated discharge at.

general features of $75-76$

Castle Creek power site, Oreg., drainage area and estimated discharge at......-

general features of

Central Avenue well, altitude of water level in .......................... 22, pl. 2

Cisco, Utah, analyses of water of Colorado River near........................ 152-153

Clayton formation, occurrence and character of.

Clear Creek power site, Oreg., drainage area and estimated discharge at.......

general features of 94-95

Climate of Rogue River Basin, Oreg., features of.
Colorado River, collection of samples of water of, for analysis.

ition of water of......... 146-148, 131-155 suspended matter carried by............ 150-158

utilization of water of ................. 149-150

weighted averages of analyses of water of. 148

Compressibility and elasticity of water-bearing formations, relation of, to drawdown of wells. 138,142

Coon Creek tongue of Ripley formation, occurrence and character of......... 15

Copper Canyon dam site, Oreg., view of...... pl. 25 Copper Canyon power site, Oreg., drainage area and estimated discharge at $\ldots$

general features of . . ............................ 90-91

plan, cross section, and area and capacity çurves of ............................. pl. 22

Covington, Tenn., analysis of water from well at

Crater Lake, Oreg., view of.................... pl

\section{D}

Darcy's law of movement of ground water.. 131, 132

Deep-well current meters.................... 125, 126

Discharge from ground-water reservoirs, methods for estimating, by evaporation from soil and transpiration from plants. 107-110

methods for estimating, by overflow ... 105-107

from daily fluctuations of the water table.............................. 116-119

method of measuring, based on groundwater rating curve.

Drainage into wells......................... 121, 122

\section{$\mathbf{E}$}

Effective size of grain, investigations of..... 133, 134

Elasticity and compressibility of water-bearing formations, relation of, to draw. down of wells.

Elk Creek power site, Oreg.,drainageareaaǹd estimated discharge at............ 54

general features of....................... $\quad 78$

Escalante Valley, Utah, methods of measuring specific yield of ground water in $\ldots \ldots$......................... 107, 141

Eutaw formation, character of .............. 14-15

water in, chemical character of............ 15

Evaporation from soil, methods for estimat ing discharge from ground-water reservoirs by.

F

Fall Creek dam site, Oreg., view of nlinois River at............................. pl. 24

Fall Creek power site, Oreg., drainage area and estimated discharge at......- 54

general foetures of......................... 98-94 
Farrar, D. F chemical analyses of water by Floods in Rogue River Basin, Oreg., maxi. mum discharge of.............. $55-56$

Flow of ground water, dye method of measuring - . . .

effective porosity measurement in determining.

electrolytic method of measuring....... 127-128 methods of measuring, based on area of influence of wells

based on field tests of velocity ..... 126-131

based on laboratory determinations of permeability 131-134

based on movements of water levels in relation to rates of withdrawal.

based on permeability determined from discharge and drawdown of wells.

134-136

Fort Caswell, N. C., investigations of movement of ground water at.

Foster, Margaret D., chemical analyses of water by.-

Gaging stations in Rogue River Basin, Oreg., periods of record of.

Gold Hill power plant, Oreg., general features of.

Gold Hill power site, Oreg., drainage area and estimated discharge at.......

general features of

Croodridge, Utah, analyses of water of San Juan River at

Grand Canyon, Ariz., analyses of water of Colorado River at........... 151-152, 155

weighted averages of analyses of water of Colorado River at

Grand Prairie region, Ark., investigations of ground water at

Green River, Utah, analyses of water of Green River at. .......................... 156-157

Grenada formation, occurrence and character of . . . .

Ground water, problem of available supplies of, present status and outlook of. 142-144

Ground-water conduits, rock formations as, general conditions of .............. 126

Ground-water reservoirs, methods of measuring leakage from.................. 124-126

rock formations as, general conditions of. 99-100

\section{H}

Hamaker power site, Oreg., drainage area and estimated discharge at general features of

amaker reservoir site, Oreg.,general features of

view of.

Hell Gate dam site, Oreg., view of pl. 11

pl. 14

Hell Gate power site, Oreg., drainage area and estimated discharge at....... general features of

Holly Springs sand, occurrenceand character of - no

water in

Horseshoe Bend dam site, Oreg., view of .... pl. 21
Horseshoe Bend power site, Orez., drainage area and estimated discharge at. $\quad 54$

general features of . ........................ 86-88

Houk, I. E., estimates of ground-water discharge by, in Miami River Basin, Ohio............................. 106

Howard, C. S., analyses of water by ....... 151-158

Quality of water of the Colorado River in 1928-1930

$145-158$.

Hydraulic structures, factors affecting....... 46-47

$$
\text { I }
$$

Illahe, Oreg., agricultural land near, view of - pl.24: nlinois River, Oreg., estimated natural flow of

profile of

regulation of flow of.................... $57-58$

Inventory method of studying ground-water supplies. 100

\section{J}

Jackson formation, character of. 17

Jones, Benjamin E., Oakey, Warren, and Stearns, Harold T., Water-power resources of the Royue River drainage basin, Oreg_............ $35-97$
Josephine Creek dam site, Oreg., view of.... pl.14 0 Judson, $T$, analyses of water by ............... 161

\section{$\mathbf{K}$}

Kerby, Oreg., discharge of nlinois River near.

Kerby dam site, Oreg., view of.................. pl.16

Kerby power site, Oreg., drainage area and estimated discharge at.............. $\quad 54$

general features of ........................

Kerby reservoir site, Oreg., general features of

lower end of, view of ....................... pl.15.

Kink finder, or gage for measuring diameter of wells. 125-126.

L

Lamar, W. L., analyses of water by 151-158.

Leakage from underground reservoirs........ 124

Lee, Charles H., studies of ground water in Owens Valley, Calif............ 100, 109

Lees Ferry, Ariz., analyses of water of Colorado River at...................... 153-154

Little Butte Creek powersite, Oreg., drainage area and estimated discharge at ..

general features of............................ 81

Loess, occurrence and character of........... 18

Long Creek power site, Oreg., drainage area and estimated discharge at........ $\quad 54$

general features of ............. 79,81

Lost Creek dam site, Oreg., view of ........... pl. 13

Lost Creek power site, Oreg., drainage area and estimated discharge at........ 54

general features of............................ 76-77

Lost Creek reservoir site, Oreg., general fear tures of .................. $60-62$

Love, S. K., analyses of water by ............ 151-158

Lundie, John, quoted........................... 2-3

Luray, Tenn., analyses of water from well at. $\quad 34$ Lysimeters, use of, for estimating intake.... 102, 103 
Mantel, r. A., chemical analyses of water by. Mariotte, Edm6, early work of 102, 103

MeKenzie, Tenn., analysis of water from well

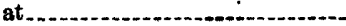

McNairy sand member of Ripley formation, occurrence and character of.......

McNeil Creek power site, general features of. Meinzer, Oscar Idward, Outline of methods for estimating ground-water supplies

Memphis Artesian Water Department, cooperation with.................... 1-2

pumpage of, from Wilcox group.18-22, 23, pl. 2 records of wells of

mphis, Tenn, altitude of Mississippi River at. - pl. 2

analyses of water from wells at. 34 chemical character of water from wells in and near. 33-34

geology of, general features of

12

history of artesian-water development in 2-12 map of, showing location of wells........ pl. 1

(in pocket)

records of wells in ......................... 5 -12

Midway group, occurrence and character of formations of.

Mill Creek Falls, Oreg., view of. pl. 10

Mill Creek power plant, Oreg., general features of.

Millington, Tenn., analysis of water from well at....

Mimbres River, N. Mex., recharge of ground water from

Mississippi River, eltitude of, at Memphis, Tenn

Mokelumne area, Calif., investigations of ground water in.

Mule Creek Canyon, Oreg., view of._......... pl, 23

\section{o}

Oakey, Warren, Jones, Benjamin E., Stearns, Harold T., and, Water-power resources of the Rogue River drainage besin, Oreg . . . . . . .

Overflow, methods for estimating discharge from ground-water reservoirs by

Owens Valley, Calif., estimates of ground water in .......................... 100, 109

Owl Creek tongue of Ripley formation, occurrence and character of

\section{$\mathbf{P}$}

Percolation from surface to water table, methods for estimating.......... 102-105

Permeability of rock formations, determinations of, from discharge and drawdown of wells. 134-136

laboratory determinations of ......... 131-134

Planet, Ariz., analyses of water of Williams River near

Pl ocene gravel deposits near Memphis, Tenn., occurrence and character of
Pomperaug Valley, Conn., method of measuxing ground-water discharge in.... 100 ,

Porters Creek clay, occurrence and character of

Power, market for, in Rogue River Basin.... $\quad 97$

Power sites in Rogue River Basin, Oreg., estimates of potential power at. 38-39

purpose and scope of investigation of.... $\quad 40$

Prospect, Oreg., discharge of Rogue River aboveand below.............. 52

Prospect power house No.2, Oreg., view of.... pl. 17

Prospect power plant, Oreg., diversion dam of, view of

general features of............................ 68 68

Prospect power site, Oreg., development of additional power at ................. $68-69$

drainage area and estimated discharge at. $\quad 54$ Pumpage from wells in Memphis, Tenn., general features of.................. 18-22

relation of, to regional drawdown......... 29-32

$$
\mathbf{R}
$$

Railroad trains, effects of, on water levels in

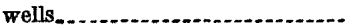

Rancheria power site, Oreg., general features of 141

Rating curve, methods of estimating groundwater supplies based on..... 119, 138-140

Raygold, Oreg., stream-flow data of Rogue River at

51

Raygold power plant, Oreg., general features of

view of ......................................... pl. 17

Raygold power site, Oreg., drainage area and estimated discharge at............. 64

Recharge of ground water by artificial means. 121 ,

Recharge of ground water by seepage from surface streams.................. 100-102

Recharge of ground-water, methods for estimating directly from rain and melted snow. 102-105

methods for estimating from surface streams........................ 100-102

Records of wells in Memphis, Tenn ......... 5-12

Reese Creek power site, Oreg., drainage area and estimated discharge at....- 54

general features of .......................... 81

Reuben Creek power plant, general features of....................................... 71

Rillito Valley, Ariz., ground-water investigations in.

Ripley formation, character of

water from, yield of ...................... 16

Riter Creek power site, Oreg., drainage area and estimated discharge at........ 54

general features of......................... 75

Rock Point dam site, Oreg., view of......... pl.20

Rock Point power site, Oreg., drainage area and estimated discharge at........ 54

general features............................. 82-83

Rogue River, Oreg., drainage area of......... 54

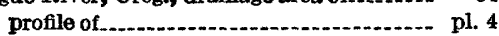

regulation of flow of ....................... 57

summary of results from storage on...... 66

views on................... pls. 5-11, 16-21, 23, 52 
Rogue Rive Basia, Oreg., annual yleld and minimum flow of streams in.

geography of

geology of.

map showing developed and proposed power sites in.

maxket for power in

moan monthly and yearly temperature in moan monthly precipitation in.

miscellaneous discharge measurements in prior water rights in

sensonal variation in stream flows in

\section{s}

Safe yield of ground water, as compared with natural intake and discharge

Salinity of water in wells, apparatus for meas-

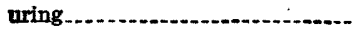

San Diego County, Calif., ground-water investigations in

Santa Clara Valley, Calif., ground-water investigations in.

Savage Rapids, Oreg., dam and pumping

plant at, view of ................ pl. 19

$157-158$

112,116

Savage Rapids power plant, general features of .

Savage Rapids power site, Oreg., drainage area and estimated discharge at..

Seepage, losses from streams by, methods for estimating 100-102

Selma formation, character of................ 15

Slichter, C. S., investigations of movement of ground water by

Smith, G. E. P., work of ............... 112

South Fork power site, general features of.... 91

Speciflc yield in relation to ground-water storage......................... 113-116

Stairs Creek power site, Oreg., drainage area and estimated discharge at........ 54

general features of.

Stearns, Harold T., Jones, Benjamin E., Oakey, Warren, and, Waterpower resources of the Rogue River drainage basin, Oreg....... 35-97

Storage of ground water, methods of measuring, general features of...-.-. 110-113

methods of measuring where use has becomelarge. 122-124

Stream flow, effects of evaporation and transpiration of ground water on...... 110

Swing Bridge dam site, Oreg., view of......... pl. 21

Bwing Bridge power site, Oreg., drainage area and estimated discharge at..

general features of -

\section{$\mathbf{T}$}

Taylor Creek dam site, view of-

Taylor Creek power site, Oreg., drainage area and estimatod discharge at..

pl. 13

general features of.......................... 84-85

Taylor Creek reservoir site, Oreg., general features of .

plan, cross section, and area and capacity curves of.
Tennesses, analyses of ground waters tron southwestern

geology of western, publications treatter of

The Dalles, Oreg., investigations of ground investigations of the movement

Thiem, A., investigations of the movement
of ground water by.....
Thiem, G., investigations of movement of ground water by

Thompson, D. G., investigations of ratingcurve method of estimating flow of ground water.................. 14, 14\%

Tidal effects on water levels in wells....... 140, 1 is

Top Creek power site, Oreg., drainage area and estimated discharge at......

general features of......................... 74-76.

Trail Creek dam site, Oreg., view of.......... pl. 20

Trail Creek power site, Oreg., drainage ares and estimated discharge at...... 54

general features of ....................... 79

Transpiration from plants, methods for estimating discharge from ground-water reservoirs by .... 107-110

Tuscaloosa formation, character of.......... 14

\section{U}

Union Creek power site, Oreg., drainage area and estimated discharge at.....-.

general features of . . .

United States Publio Health Service, investigations of, at Fort Caswell,

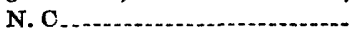

Uranin dye, use of, in investigating movement of ground water.

\section{$\mathbf{V}$}

Velocity of ground water, methods of measuring . ................... 128-131

W

Water levels in wells, evaluation of extranoous influences on................ 140-142

Water power in Rogue River Basin, Oreg., sites for development of, general features of.

Water spreading to increase ground-water recharge

Water table, methods of estimating groundwater supplies based on daily fluctuations of .

Wells, F. G., A preliminary report on the artesian water supply of Memphis, Tenn..................... 1-34

Wells in Memphis, Tenn., original statio level in ............................ $28-8$

seasonal fluctuation of head in.......... 22-28.

White, W. N., investigations by, of discharge of ground water by plants .. 107, 118, 141

Wilcox group, occurrence and character of formations of...................... 10-17

pumpage of Memphis Artesian Water Department from....... 18-22, 23, pl. 2

Williams, K. T., analyses of water by..... 158-115 Williams River, analyses of water of........ 16 